The Journal of afgricuturue of the University of Puerto Rico

In continuation of The Journal of the Department of Agriculture of Puerto Rico

Published by The Agricultural Experiment Station, Rio Piedras, P. R.

Pablished Quarterly: January, April, July and 0ctober of each year.

Metville T. CoOK, Edxor

VOL. XXI

JULY 1937

No. 3

\title{
A BIBLIOGRAPHY OF IMYCOLOGY AND PHYTOPATHOLOGY OF CENTRAL AND SOUTH AMERICA, MEXICO AND THE WEST INDIES
}

By José I. Otero, Librarian and Melville T. Cook, Plant Pathologist ${ }^{5}$

We present this compilation in the hope that it may be useful to students and research workers not only in these countries but also in other countries.

This bibliography was started independently by the co-authors, one forced by the everyday needs of references to the tropical American literature in connection with his work in plant pathology; the other in his bibliographical work in the library. Since both were interested in the same work it was decided to make it a joined publication which would be of service to the greatest number of workers.

Accordingly a project was drawn by the senior author and the work started for a strictly mycological publication. However, the publications on mycology are so intimately related with plant pathology that it was very soon decided to include both subjects. Therefore, this work may be said to have started when the junior author came to Puerto Rico in 1923 but was definitely organized in its present form in 1930.

It was originally intended by the senior author to append this bibliography to a Host Plant Index to the Fungi of the West Indies, Mexico and Central and South America now in progress but this plan was abandoned and it is presented to the workers in mycology and plant pathology in its present form.

The work on the Host Plant Index demonstrated the great difficulty in collecting data in mycology from the literature covered by this publication. The literature from these parts of the world is not restricted to these countries but many papers have been published in Europe and North America, and in several languages. 
The compilers intend to follow as closely as possible the following features in this bibliography, with the idea of making it most helpful to students and workers:

(a) It is arranged alphabetically by authors and cronologically under the name of each author, taking always the senior author as guide in cases of more than one.

(b) When it has been possible we have used the author's full name which enabled us to verify the correctness of many of the citations and avoid confusion and errors in authorship.

(c) Most titles appear first in the original language with translations into English in parenthesis. In some cases it has not been possible to obtain the original paper and in those cases the translated titles appear in parenthesis. Some titles appear only in the original language.

(d) When an article appears in more than one publication all except the first paper appear in parenthesis.

(e) We have not been able to see all the original papers; therefore there are many which we have been unable to annotate.

( $f$ ) Many taxonomic, most of the mycological papers and many of the popular papers which do not include any record of a disease or a fungus have not been annotated.

In some cases, the titles of the papers do not indicate the character or the value of the contents. These papers have been inserted with the proper explanatory data.

The authors fully appreciate that some of the literature has not been found and that there may be some errors in this publication. Therefore, we will be pleased to have the workers send us corrections and additions for use in a supplement. 
A. K. B. Mycological Notes. Trop. Agric. (Trinidad) 6(11) : 317. 1929.

Refers to a paper by S. F. Ashby on "Lime and sugar-cane diseases in the West Indies' in Bull. of Misc. Inf. Royal Bot. Garden. Kew, No. 7. 1929.

Refers to Sphaerostilbe repens, Fusarium sp., Phomopsis sp., and Botryodiplodia theobromae all of which are saprophytic and sometimes weak parasites on the lime. Also to Gloeosporium limetticolum which is serious in Dominica and St. Lucia. Also to the gumming disease (Bacterium vascularum) on cane.

Abbot, F[rnest] V[ictor] \& Townsend, C[harles] H[enry] T[yler]

El Mosaico de la caña de azúcar y su transmisión. (Sugar Cane Mosaic and its transmission. Est. Exp. Agric. Soc. Nac. Agric. Lima (Perú) Circ. 5, 10 p., 1928.

Popular discussion of the subject.

Plagas fungosas de los vegetales. (Fungous diseases of vegetables). Est. Exp. Agric. Soc. Nac. Agric. Lima (Perú) Informe 4, 11 p. 1928.

La "Roña" y la "mancha" o "hielo" de la papa. (Scab and rot or blight of potato.) Estac. Exper. Agric. Soc. Nac. Agrar., Lima, Perú, Cir. 7, 11 p. 1928.

Refers to Spongospora subterranea and Phytophthora infestans.

Una nueva enfermedad de la papa (A new disease of potato.) Vida Agric. (Perú) 6(66) : 181, 1929.

This disease is attributed to Aecidium cantensis.

Stem rust of wheat in Perú. Phytopathology 19(11) : 10411043, 1929.

A discussion of Puccinia graminis tritici with reference to varieties of wheat and methods of distribution.

La "Marchitez" del algodón (Wilting of the cotton plant.) Vida Agric. (Perú) 7(77) : 274-281, 1930.

Attention is called to the annual losses due to this disease.

Informe del Jefe de la Sección de fitopatología. Mem. Estac. Exp. Ágric. Soc. Nacion. Agrar. (Perú) 2: 85-101, 1930.

A report of field studies of various diseases. The following fungi are mentioned,-Puccinia triticinia, Erysiphe graminis of wheat, Helminthosporium sativum, $H$. teres, Ustilago muda and Rhynchosporium secalis. Recommendations for potato blight control are given.

Diseases of economic plants in Perú. Phytopathology 19(7): 645-656, 1929.

Reference to mosaic of sugar cane and other plant diseases. 


\section{Wolcott, G[eorge] $\mathbf{N}$ [orton]}

Mosaic of Sugar Cane in Perú. Science 69(1788) : 381, 1929.

Account of the occurrence of mosaic disease of sugar cane in Perú and of the abundance of Aphis maidis Fitch., its insects vector.

A new host for sugar cane mosaic. Phytopathology 20(1): 109, 1930.

Refers to our "caña india" known as "caña brava" (Gynerium saggitatum). Growing in or near cane fields becomes infested with mosaic.

Further notes on plant diseases in Perú. Phytopathology 21(11) 1061-1071, 1931.

Enfermedades de las plantas cultivadas en el Perú. (Diseases of cultivated plants in Perú). Lima Estac. Expt. Agric. La Molina. Circ. 18, 76 p., 1931. (Bol. Agrie. \& Ganad. (Perú) No. 1, 76 p., 1932.)

A powdery mildew on cotton from Perú. (Erysiphe malachrae). Mycologia 24(1): 4-6, 1932.

Acosta, D. R.

Investigaciones fitopatológicas. (Phytopathological investigations). Min. Indus. Dirc. Agron. (Uruguay) Publ. Mens. 1: 1-18, 1931.

A list is given of the diseases of the principal crops and other economies and ornamental plants observed in Uruguay.

Agostini, A.

Coconut diseases and beetles. Proc. Agric. Soc. Trinidad and Tobago 13(11) : 561-566, 1913.

A popular paper in which bud rot and root disease are mentioned.

Alamo Ibarra, Roberto.

El mosaico, matizado o rayas amarillas de la caña de azúcar. (Mosaic, mottling or yellow stripe disease of sugar cane.) Venzuela Min. de Fomento, Panfleto, 55 p., 1927.

Popular discussion of mosaic of sugar cane under Venezuelan conditions.

Alazraqui, J.

Gomosis bacilar y "Court noue", en los viñedos de Mendoza.

(Bacterial gummosis and "court noue" on the vines of Mendoza.) Mins. Agric. 1910. 


\section{Alfaro, Julio.}

A new method of fighting the Propagation of Mosaic disease in sugar eane. Planter \& Sugar Manuf. 75(20):388-389, 1925. (Sugar 28(1): 45, 1925. Trop. Agx. (Ceylon) 66(2): 113-114, 1925. El Mundo Azucarero 13(5): 150, 1925. Proc. Agric. Soc. Trinidad \& Tobago 25(2): 437-439, 1925.)

Recommends the use of resistant varieties.

Statement of Mosaic control. Proc. Conf. Int. Soc. Sugar Cane Tech. (Havana) 2:9199, 1927.

\section{Altson, R[alph] A[bbey]}

Plant disease investigations. Brit. Guiana Dept. Sci. \& Agric. Ann. Rpt. 1924 : 45-53, 1924.

Brief notes on coffee wilt.

Report on a suspected outbreal of infectious mosaic disease among certain canes in the colony. Journ. Bd. Agr. British Guiana 18(3) : 216-235, 1925. (Int. Sugar Journ. 27(318) : 293, 1925.)

Gives record of losses due to mosaic which is the nost serious problem in Jamaica. Considers the case of British Guiana which was supposed to be a case of mosaie but proved to be non-infectious chlorosis.

Report on a visit to Jamaica, Costa Rica and Trinidad, Journ. Board of Agric. British Guiana, 18(1) : 2-19, 1925.

British Guiana, Reports of the Department of Science and Agrieulture for the year ending 31st. December 1925, 1926.

This report contains brief reference to root diseases, rind disease (Melanconium sacchari), red spot (Cercospora vaginae), Thielaviopsis paradoxa and Stemonitis herbatica of sugar cane. Also rice blast, witches' broom (Mrarasmius perniciosus) and pod rot (Phytophthora faberi.) of cacto, wilt of coconut and Papulospora disease of coffee.

Appendix III, Report of the Assistant Botanist and Mycologist. Rept. Dept. of Sei. and Agric. Brit. Guiana for year 1924, p. 45-54, 1926.

Gives a list of important diseases.

The occurrence of Sclerotium disease of coffee in the Northwest District. British Guiana Combined Court. 32:1-5, 1926.

The author states that there is sufficient evidence to believe that the fungus Sclerotium coffeicolum has been in the colony for about 10 or 12 years previous to its first report of damages in British Guiana. He describes the damages caused by this parasitic fungus but has not been able to find an adequate treatment. He recommends spraying with Bordeaux mixture. 
THE JOURNAL OF AGRICULTURE OF THE UNIVERSITY OF $P$.

Plant disease. British Guiana Dept. Sci. Agr. Rpt. p. 43-45, 1926.

The most outstanding item in this report is the finding of the fungus Sclerotium coffeicolum in the coffee groves of the northeastern coffee districts. It is suspecting that it has been in the colony for ten years before being reported.

Plant disease investigations in British Guiana. Brt. Guiana Dept. Sci. \& Agric. Ann. Rpt. p. 39-43, 1926.

This report contains among other items, notes on coffee wilt caused by the fungus Papulospora. (१) sp.

Memorandum on Panama disease. Journ. Board of Agric. British Guiana 20(2) : 88-90, 1927.

A report on Fusarium cubense. Also mentions Bacterium solanacearum, Ustilaginoidella oedipigera, and Gloeosporium musarum on banana.

\section{Alvarado, J. Antonio}

La gotera en los cafetales (The "Gotera" of the coffee groves).

Rev. Cafetera de Colombia 5(51-53) : 1726-1729, 1933.

A general account of the disease commonly called "gotera". It is caused by the fungus Stilbella flavida. The author describes the disease, its nature, damages caused to coffee and general treatment, especially in the nurseries.

\section{Amaral, A[velardo], Afranio Pompeu}

O mosaic. Bol. Agri. (Sao Paulo) Brazil, 27:47-156, 1926.

Auchinleck, G. G.

Root disease of cacao in Grenada. Proc. Agri. \& Com. Soc.

Grenada Appendix II, p., 159-160, 1910.

\section{Anonymous}

Notes. Ann. Soc. Entomo. de France. Bul. 11 p. 11, 1842.

(Rev. Zool., p. 126-127, 1842.)

Notes on the work of Gueren-Meneville \& Perrottet.

Omitted diagnosis. Grevilles 19:71-75, 1891.

Taxonomic, includes, Helotium Venezuelianum (Klot) Phil., Phialea furfuripes (Berk. \& Curt.) Phil., Bulgaria microspora Berk. from Venezuela.

Cane diseases in Pernambuco. The sugar cane, Manchester 26: 377-379, 1894.

Editorial. The Sugar Cane, Manchester 26:505,1894.

A sarcastic statement concerning the work of scientists. No value. 
(Plant disease observed in 1894 and 1895.) Relat. Inst. Agron. Sao Paulo, (7-8) : 319-326, 1896.

Among the diseases and pests of the coffee tree mentioned in this report, are a disease of the coffee leaf (Alternaria sp.) and a mildew. Other plant disease data is given.

La fugosidad y el pulgón de los cafetales en la República de Méjico. Méjico, Ministerio de Fomento Colonización e Industria 11 p., 1897.

Danger of introducing a Central American coffee in Hawaii. U.S.D.A. Div. Veg. Phy. \& Path. Cire. 16, 1898.

Cacao diseases in Trinidad. Kew. Misc. Bull. 145-146: 1-6, 1899.

The cacao pod disease. Trinidad Bull. Roy. Bot. Gard. 3(2): 183-185, 1899.

The cacao disease in Trinidad. Trinidad Bull. Roy. Bot. Gard. $21: 221,1899$.

The cacao disease. Trinidad Bot. Dept. Bull. Mise. Inform. $27: 328,1901$.

The "witch broom" disease on cacao in Surinam. West Indian Bull. 2: 289-291, 1901.

This refers to a paper by Went in Fijd-schrift voor Plantenziekten for 1900 and shorter papers in Zeitschrift für Pflanzen Krankheiten for 1901 and Journal d' Agriculture Tropicale for 1901. These studies were made in Surinam.

Canker in cacao. Journ. Jamaica Agric. Soc. 7(11):450-451, 1903.

Cacao canker and its eradication. Trop. Agric. (Ceylon) 23 (1) : 31, 1903 .

The witches' broom disease of cacao. Agric. News, (Barbados) $2(26): 117,1903$.

A bacterial rot of onion. West Indian Bull. 5(2) : 134-139, 1904. A discussion of this disease which occurred in Barbados. Name of organism not given. 
THE JOURNAL OF AGRICULTURE OF THE UNIVERSITY OF P. $R$.

Bud-rot disease of cocoa-nut palm. West Indian Bull. 6(3): 307-328, 1905.

A general discussion.

Witch broom disease of cacao. Agric. News (Barbados) 4(78): 105, 1905.

Pod diseases of cacao. Agric. News (Barbados) 4(83) : 189, 1905.

Cacao disease in Surinam. Trop. Life 1(1):12, 1905.

Cacao diseases. Bull. Dept. Agric. Jamaica. 3(12) : 270, 1905.

Field treatment of cane tops for planting purposes. West Indian Bull. 6(1) : 48-52, 1905.

This note refers to an article in West Indian Bulletin 5:96-103. It gives the results of treatment.

Cacao disease II. Bull. Jamaica Dept. Agric. 4(1) : 11-13, 1906.

A new disease of cacao. Agric. News (Barbados) 6(128):93, 1907.

Diseases of coconut palms. Agric. News. 5(6): 1907 .

A brief discussion of root disease. (Botryodiplodia sp.), leaf disease (Pestalozzia sp.) and bud rot.

Root disease of sugar cane. Soc. paper 302, Proc. Agric. Soc. 8: 101-104, 1908.

Popular discussion of Marasmius sacchari.

Sugar-cane diseases in Antigua, Agric. News. 7(158): 155, 1908. Extract from Report by Stockdale on Marasmius sacchari.

The principal fungus diseases of cacao. Agric. News. 7(163): 237, 1908.

Popular note on pink disease (Corticium lilaco-fuscum), root disease, brown pod (Diplodia cacaoicola) and black pod (Phytophthora. omnivora).

Fungus diseases of eacao. Agric. News 7(166): 273-274, 1908.

Popular note referring to Stockdale' report in West Indian Bull. 9(2): which was also published in booklet as No. 54 in Pamphlet series of the Department. 
The coconut bud-rot in Cuba. Science n. s. 28(706:57-58, 1908. A statement in regard to an appropriation for the study of this disease.

Disease of ground nuts in Dominica. Agric. News, (Barbados) $8: 315,1909$.

A severe disease which is possibly due to a fungus-Septogloeum arachidis.

Eel worms or nematodes. Agric. News (Barbados) 8: 138, 1909.

Refers to Heterodera radicola in Antigua, St. Lucía, St. Vincent and Barbados.

A coffee disease in Dominica. Agric. News (Barbados) 8(193): 292, 1909.

Brief notes on the fungus Stitbella flavida attacking coffee berry. Preventive measures are recommended.

Diseases of ground nuts. Agric. News (Barbados) 3:347, 1909.

A species of Uromyces was reported from St. Vincent in 1908. A fungus which may be the same was reported from Montserrat in 1907 as Uredo sp.

A coffee disease in the new world. Agric. News (Barbados) 8: 395, 1909.

This note quotes from No. 8 of the current volume of Kew Bulletin in which Massee describes a fungus as Sphaerostilbe flavida.

The disease and the fungus are figured on page 411.

Cacao diseases in Surinam. Agric. News (Barbados) 9:46, 1910. This note refers to Bulletins 20 and 21 of the Department of Agriculture of Surinam.

The canker or red disease is described. Mr. A. E. Van Hall finds that the disease caused by a new species of Spicaria (S. colorans) and that the Nectria (probably N. striatospora) frequently found on diseased trees is a saprophyte.

This disease in the West Indies is believed to be due to Nectria theobromae and Calonectria flavida.

Die-back and brown rot appears to be due to Diplodia cacaoicola. It was originally believed that the Surinam disease was due to Chaetodiplodia but they are the same. Lasiodiplodia sp. is also the same.

Trinidad Fungi. Soc. paper 408. Proc. Agric. Soc. Trinidad \& Tobago 10: 87-90, 1910.

This paper gives the following list of fungi: Hartiella n.g. coccinea Massee. On cocoa pods in Trinidad. Aphiobolus calathus Massee 
on dead wood in Trinidad Scleroderris gigaspora Massee on scale insects (Mylilaspis citricola) on orange leaves. Hendersonia microspora Massee on fallen orange leaves in Trinidad. Gloeosporium citri Massee on fallen orange leaves in Trinidad.

All the above species are described in this paper and in Kew Bulletin No. 1, 1910. Xylaria pattersonii Massee, was found in St. Vincent and is described in this same number of Kew Bulletin.

Cacao Canker. Agric. News (Barbados) 9(214) : 222-223, 1910.

Some diseases of rubber trees. Agric. News (Barbados) 9(219): 302-303, (220): 318, (221) : 334-335, 1910.

Two interesting fungi in St. Lucia, Agric. News (Barbados) $9: 286,1910$.

Additional note on pink disease. Agric. News (Barbados) 9, 382-383, 1910.

This note refers to the above. It reports Corticum lilacino-fuscum on pigeon pea.

Miscellaneous fungi recently examined. Agric. News (Barbados) $9: 398-399,1910$.

These fungi appear to have been found in St. Vincent. They are Ustilago sorgii on Guinea corn (Andropogon sorghum, var. vulgare.) Cercospora beticola on beets and Uredo vitis Thümen on grape leaves.

The root disease of sugar cane in Barbados. West Indian Bulletin 10(4) : 347-349, 1910.

A discussion of Marasmius sacchari.

The fungus causing pine-apple disease. Agric. News (Barbados) $10: 126,1911$.

This is a history Thielaviopsis paradoxa.

Diseases of Pine-apple. Agric. News (Barbados) 10:142, 158, 1911.

Also a discussion of Thielaviopsis paradoxa.

Arrow root disease. Agric. News (Barbados) 10: 174-175, 1911.

Refers to a fungous disease but does not give the name of the fungus.

The die-back fungus of Para rubber and of Cacao. Agric. News (Barbados) 10:286, 1911.

This note refers to studies on die back by C. K., Bancroft of Federated Malay States. He says that the fungus Lasiodiplodia theobromae should be known as Thyridaria tarda. 
Cacao-spraying "experiment in Grenada. Agric. News (Barbados) $10: 308,1911$.

Gives methods and results.

Observations on root disease in the West Indies. Part I. Agric.

News (Barbados) 10:366, 1911. Part II. Agric. News (Barbados) $10: 382,1911$.

General.

Eel-worms or nematodes. Heterodera radicicola (Greef) Mull. Agric. News (Barbados) 11: 138, 154, 1912.

A report on fungus diseases during the years 1910 and 1911. Agric. News (Barbados) 11:30-31, 1912.

Refers to Melanconium sacchari on cane in St Vincent; Colletotrichum gossypii on cotton in St. Vincent; Phytophthora faberi on cacao in St. Lucía; Rosellinia sp. and Sphaerostilbe sp. on limes in Dominica; Fomes lucidus on eacao in Montserrat and Antigua; Cercospora personata on ground nuts in Nevis; Uredo arachidis on groundnut in Dominica, Montserrat and St. Kitts.

Plant diseases and pests, etc. West Indian Bulletin 12(2) : 175185, 1912.

This paper contains some records of entomogenous fungi, of red rot (Colletotrichum falcatum) in Antigua and of bacterial boll rot of cotton in St Vincent.

Immortal canker. Agric. News (Barbados) 11: 74, 1912.

A disease of immortel (Erythrina umbrosa) is reported in St. Lucia. May be same as disease in Ceylon caused by Phytophthora faberi.

Rose mildew. Agric. News (Brabados) 11:174, 1912.

Scientific name not given. Method of control given.

Three fruit diseases and and their control. Agric. News (Barbados) $11: 334-335,1912$.

This note refers to (1) a disease of the mango caused by Gloeosporium mangiferae; (2) a disease of Avocado caused by Colletotrichum gloeosporioides, and a disease of bread fruit described by Stockdale in Journ. Board of Agric. British Guiana 6:14.

Coconut diseases in tobaceo. Agric. News (Barbados) 11:398399, 1912.

This note refers to a root disease. Cause not given. 
A disease of tanias. Agric. News (Barbados) 12:30, 1913.

This disease is eaused by a fungus described by Ashby as Hosmriscium colacasiae.

A root disease of Paspalum dilatatum. Agric. News (Barbados) $12: 94,1913$.

This disease is reported in the Report of the Botanical Station, Montserrat. 1910-15: 15. It is similar to the disease of sugar cane caused by Marasmius sacchari.

Red rot fungus and sugar cane in the West Indies. Agric. News (Barbados) 12:126, 127, 142, 143, 158, 159, 1918.

Historical.

New Exotic Fungi. Agric. News (Barbados) 12:206, 1913.

This note refers to Kew Bulletin No. 3, 1913, in which a fungus collected by South of St. Vincent is mentioned. It is Gloeosporium cocophilum Wakefield and was found on petiole of coconut palm (Cocus nucifera).

Recent French work on diseases of Hevea and cacao. Agric. News (Barbados) 12:270, 1913.

This note refers to Dothidella ulei on leaves of Hevea, in Brazil.

Witch broom disease of cacao. Agric. News (Barbados) 12:302, 303, 1913.

This note refers to a paper of Rorer just issued by the Board of Agric. of Trinidad and Tobago in which he says that the diseaseis caused by a Basidiomycetous fungus and not by Colletotrichum luxificum. This is followed by some good historical data.

Contamination of soil by the toxic products of parasitic fungi. Agric. News (Barbados) 12: 334, 1913.

This note refers to an article in Monthly Bulletin of Agricultural Inteligence and Plant Diseases (April, 1913.)

Black spot of rose leaves. Agric. News (Barbados) 13:14, 1914. Popular. Cause not given.

Fomes semitostus in British Guiana. 13:14, 1914.

This note refers to a note by C. K. Bancroft in Journ. Board of Agric. for British Guiana. Oct. 1913. This fungus oceurs on stumps of unknown trees. 
Mycological notes. Witch broom disease of cacao. Dept. Agric. Trinidad and Tobago, Bulletin 13(84) : 323, 1914.

A note attributing the disease to Colletotrichum luxificum.

Leaf-cut or tomosis, a disorder of cotton seedlings. Agric. News (Barbados) $13: 126,1914$.

Refers to a disease on St. Croix which resembles the disease deseribed by O. TF. Cook.

A parasite on coffee. Agrie. News (Barbados) $13: 141,1914$.

This note quotes from Monthly Bulletin of Agricultural Intelligence and Plant Diseases (Jan., 1911) as follows: "Stilbum flavidum, Cooke, is well known throughout tropical and sub-tropieal Ameriea as the cause of roundish dry spots on the leaves of coffee. The writers have recently studied this fungus in the neighborlood of Rio de Janeiro on eoffee and other plants. (Eriobotrya japonica and various Melastomaceae, Compositae and Rubiaceae). There is little doubt that $S$. favidum occurs naturally in the forests on various shrubs. This origin explains the local distribution of the fungus which in Brazil oecurs chiefly in the coastal regions, where it finds the heat and moisture necessary for its development."

"All attempts at further classification had been unsuceessful owing to the sterility of the fungus. In moist chamber the writer has at least obtained fructifications of a typieal Agrie. the character of which refers it to the genus Omphalia; it apparently constitutes a new species (O. flavida).",

Fungoid disease in Barbados. 1912-13. Agric. New (Barbados) $13: 158,1914$.

This note refers to the Am. Report of the Barbados Dept. of Agric. for the year ending Narch 31, 1913. It records Hfarasimus sacchari and Colletotrichum falcatum on sugar eane; Eutypa erumpens on Ficus nitida, Coniothecium sp. on limes; Actinonema rosae Probably same as Diaoceum (Alarssonia) rosea and Sphaerotheca pannosa on roses; and Uncinula spiralis on the vine.

Two tomato diseases. A Agrie. News (Barbados) 13:174,1914.

Two diseases in Barbados on tomatos grown from American seed. Leaf mould (Cladosporium fulvum (ke) and blossom end rot.

Base root of pine-apples. Agric. News (Barbados) 13i: 190, 1914.

Disease found in St. Kitts is due to Thielaviopsis paradoxa Went.

Black root disease of lime". Agrie. News (Barbados) $13: 346$, 1914.

A report on a disease in Dominica eaused by Rosellinia bunodes. Also a deseription of the disease. 
Wilt disease of leguminous plants. Agric. News (Barbados) $13: 348,1914$.

A disease of Tephrosia candida in Montserrat; said to be due to Neocosmospora vasinfecta E. F. S.

Molestia do afeeiro (Coffee diseases) Bol. Agric. Sec. Agric. Com. \& Obras, S. Paulo (Brazil) 16(1): 69-75, 1915.

Detailed discussion on the fungus, Stilbella flavida (Cooke) Lind., giving description, distribution and damages caused by it.

Plant diseases and pests. Trinidad \& Tobago Dept. Agric. Bull. $14(2): 62,1915$.

Cacao thrips and die-back in St. Vincent. Agric. News (Barbados) $15(369): 206-207,(370): 222-223,1915$.

The cause of the witch-broom in Cacao. Journ. Bd. Agric. British Guiana. 9:1-3, 1915.

This disease reported by Ritzema Bos due to Exoascus theobromae; Howard found spores of Fusarium and suspected Nectria sp.; Charles suspected Lasiodiplodia; van Hall and Drost said it was due to Colletotrichum luxificum. Recently Stahl said it was due to Marasmus perniciosus.

Rusts and smuts of indian corn. Agric. News (Barbados) 14: 78, 1915.

This note refers to these diseases but the only one definitely recorded is Ustilago Zea (Beck.) Ung., which the author reports as widely distributed throughout the West Indies.

Preliminary note on a disease of Carica papaya. Agric. News (Barbados) 14: 174, 1915.

A stem disease that may be due to Colletotrichum sp.

Diseases of cassava in Trinidad. Agric. News (Barbados) 14: 174, 1915.

This paper refers to Cercospora sp., Gloeosporium manihot and Bacillus Manihotus as occuring in some tropical countries but does not made a definite statement in regard to locality. However, he does say that the Rosellinia root rot oecurs on bath eassava and eacao in the Lesser Antilles.

A new form of black root disease of cacao. Agric. News (Barbados) $14: 254,255,1915$.

An extract from report by Wm. Nowell to the Imperial Department of Agriculture. The disease is reported in wet districts of Grenada, St. Lucía and Dominica and is said to originate in stumps of Piptadenia peregrina. 
The entomogenous fungi of Porto Rico. Agric. News (Barbados) $14: 286,1915$.

Refers to a report of J. R. Johnston.

Die-back of lime trees in Miontserrat. Agric. News (Barbados) $14: 318,319,1915$.

Extract from a report made to the Imperial Commissioner of Agriculture. The disease resembles that caused by Colletotrichum gloeosporioides.

The internal disease of cotton bolls. Agric. News (Barbados) $14: 222,238,239,1915$.

This disease is reported from Montserrat, Antigua, St. Vincent and Tortola. It is attributed to Bacterium malvacearum.

Spraying of ground nuts for leaf rust. Agric. News (Barbados) $14: 350,1915$.

The disease is caused by Oredo arachidis Lag., and is reported from Montserrat.

Some new entomogenous fungi in St. Vincent. 15:110, 1916.

An indefinite report on some fungi and a definite report of fungus resembling Septobasidium pedicullatum Schiven on Aulacaspis pentagona in St. Lucia. He also reports Ophironectria coccicola E. \& E.

Marasmins perniciosus n. sp. cause of witch broom on the cacaotree in Surinam. Int. Rev. Sci. \& Pract. Agric. 7(1) : 158-159, 1916.

Pineapple wilt. Agric. News 15:174, 175, 1916. (West Indian Bull. 8: 158-161, 1916).

A new cane disease in Puerto Rico. Report Bd. Commissioner Agr. 1914-15: 270, 1916.

This note refers to Cytospora sacchari.

Rosellinia root diseases in the Lesser Antilles. Agric. News (Barbados) 15: 382, 1916.

This note is an extract from a paper by Wm. Nowell in West Indian Bulletin 16(1). He says that Rosellinia disease occurs in Guadaloupe, Dominica, Martinique, St. Lucia, St. Vincent and Grenada. It occurs on cacao on all these islands, on coffee in Guadeloupe and Martinique; on limes in new clearings in Dominica and on arrow root in the interior of St. Vincent. The disease on cacao is caused by $R$. pepo; the disease on limes and coffee by $R$. pepo and $R$. bunodes. 
Affections of lime seedlings. Agric. News (Barbados) 15:414, 1916.

A damping off disease in Montserrat eaused by one of the downy mildews (Peronosporaceae).

The fungus on cacao thrips. Agric. News (Barbados) 15:430, 1916.

Reports a fungus (Sporotrichum globuliferum on eacao thrips Heliothrips mbrociveta) in St. Vincent. This fungus was first deseribed by Spegazzini on material on bodies of dead beetles in Argentina.

Report on the prevalence of some pests and diseases in the West Indies during 1915. Compiled from Reports of the principal local Agricultural Officers. West Indian Bull. (Barbados) 16(1): 1-30; 309-331. 1916.

A collar disease of pigeon peas. Agric. News (Barbados) 16: 78, 1917.

This is a report of a disease of Cajanus indicus in Granada. Causenot given.

Preliminary trials with the cacao thrips. Agric. News 16:94, 1917.

This note refers to a note in Agricultural News 15:430. The fungus is Sporotrichum globuliferum. It was sprayed on plants in plots in the Botanic Garden but the weather was dry and only one insect was. found to be parasitized. When sprayed on plants in boxes so as to retain a high humidity many insects were parasitized. The green muscardine fungus Metarluzium anisopliae was used in boxes with same result.

Internal disease of cotton bolls in the West Indies. Agric. News (Barbados) 16: 318, 1917.

This note refers to a paper by Nowell in West Indian Bulletin, Vol. 16(3) Sept. 10, 1917. This disease appear to due to a fungus Eremothecium cymbalonia or to bacteria which gains entrance through injuries by Dysdescus spp. and Nezara vividula.

Plant diseases. Agric. News 16: 331, 332, 350, 1917.

This note refers to a report by Nowell in Dominica. Official Gazette, Aug. 27, 1917, in which the author reports Nectria and Stilbum spp. 
Plant diseases in Barbados in 1917. Agricultural News (Bar bados) $17: 78,1918$.

This note refers to the Ammual Report of the Barbados Dept. of Agric. (issued as a Supplement to the Oficial Gazette, Jan. 24, 1818). It recorded Marasmius sacchari, Colletoinchum falcatum. Cercospora vaginae, and Cophalosporium sacchari on sugar cane.

Internal disease of cotton bolk in the West ndies. Agric. News (Barbarlos) $17: 238,1918$.

A diseussion.

Gitrus discases in luba. Anre. News (Barbados) 16:142, 1919.

This note refers to California Bulletin by II. S. Faweett and reported the following diseases in Cuba: Alal al gomma or foot rot, psorosis, or California sealy bart, Diplodia gummosi due to Diplodia natalensis, a gum disease of lemon trees different from Pythiacystis or Botrytis gummosis in California or foot rot in Florida. The most serious gummosis in Cuba appears to be due to Pythiacystis probabiy 7 . Citrophthord. Other diseases were seab due to Cladospo-

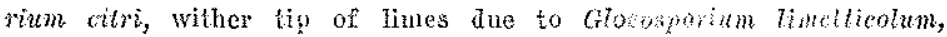
blossom end rot of Persian limes, Diploria rot (Diglodin natalensis), leaf spot due to Mycoidca parasitita, black mohnose or greasy spot.

Plant diseases in Jamaica. Agric. News (Barbados) 18:30, 1919 .

This note refers to Ashby's report for Dept. of Agrie. of Jamaica, Marel $31,191 \mathrm{~s}$. The diseases reterten to are the Panama disease of banana in which are found a Fusaria similur to $F$, thanfectum and $\%$ radisteola; bud rot of coconut in which le found a fungus (probably Pythinn palwianum); leaf bitten or bite of coconat; apjarently a species of Ahnon on swod potato npparently Rostrelle colfoac on pimento although coffee in the same nicid was not discased; Corticium ramem rar, anlani on yams; Phyfonththora infetan on potato; honey pomb disense of popra caused by Batcillus mescnterious vulgatus; Aschersonia aloyroids, Aegenta wobemi and Fortinillatm hotcrocladium on insects.

Disposiciones vigentes sobre el servicio de sanidad vegetal. (Regulation in force relating to the sanitation service.) Ofic. Sanidad Veg. See. Agr. Com. \& Trab. (Cuba) 32 p., 1919.

Quarantine regulations.

Plant legislation in Domiuica. Agric. News (Barbados) 18: $292,1919$.

Quarantine regulations. 
Degeneración de la papa y manera de evitarla. (Degeneration of the potato and means of preventing it.) Rev. Agr. (México) 4: 415-421, 1919.

The author attributes the disease to Phytophthora infestans and other fungi.

Plant legislation in Dominica. Agric. News (Barbados) 18: 237, 1919.

Quarantine regulations.

Report on the prevalence of some pests and diseases in the West Indies during 1919. West Indian Bull. 19(1):1837, 1919.

Important records.

The mottling disease of sugar cane. Agric. News (Barbados) $18: 62,63,1919$.

This note is a discussion of earlier circular 14.

Chlorosis of sugar cane. Agric. News (Barbados) 18:68, 69, 1919.

This note refers to an article by Tempany in West Indian Bull. 16: 137 in regard to areas of chlorotic cane in Antigua. They appear to be due to excessive calcium carbonate. The note refers to similar conditions in cane fields of Puerto Rico and in pine-apple field of Hawaii.

Recent plant legislation in Granada. Agric. News (Barbados) $18: 169,1919$.

Quarantine regulations.

Report on the prevalence of some pests and diseases in the West Indies during 1920. West Indian Bull. 19(1) : 237-271, 1920. Important records.

Mosaic or mottling disease of sugar cane. Agric. News (Barbados) $19: 345,1920$.

Popular.

Mosaic disease of canes. Journ. Jamaica Agric. Soc. 24:313314, 1920 .

Government regulation for eradication.

El mildiew o blanco de los zapallos. (Cucumber mildew.) Defensa Agric. (Uruguay) 1(1):12-13, 1920.

The Bordeaux treatment for Powdery mildew (Oidium sp.) of cucumbers. 
Cura de las semillas de trigo. (Treatment of seed wheat.) Defensa Agrícola (Uruguay) 1:115-119, 1920.

Copper sulphate and formalin treatments.

Enfermedades de las plantas producidas por hongos. (Plant diseases produced by fungi.) Defensa Agric. (Uruguay) 1: 79-83, 1920.

Popular.

Report on the prevalence of some pests and diseases in the West Indies during 1918. West Indian Bull. 18:34-36, 1920.

A list of diseases compiled from reports from the colonies under Imperial Department of Agriculture.

Porto Rico fights eane mottling disease. Sugar 22:208-210, 1920.

A review of recent publication in Puerto Rico.

Plaga blanca de las cebollas. (White disease of onions.) Rev. Agric. (México) 5: 601-602, 1920.

The disease is eaused by a Fusarium sp.

The watery or monilia disease of eacao pods. Agric. News (Barbados) 19(470): 142, 143, 1920.

This disease is reported from Ecuador in a handbook by Rorer in 1918. It is believed to be indigenous to that country. It is described in this note.

Black spot and dark rot of eacao. Agric. News (Barbados) $19: 206,1920$.

This note is based on Rorer's hand book. The disease has not been reported from any country other than Ecuador. It is a wound parasite caused by Sphaeronema sp. The disease and the fungus are described and preventive measure recommended.

Investigation of the froghopper pest and disease of sugar cane. Agric. News (Barbados) 18: 174-175, 190-191, 222-223, 1919.

This note includes a diseussion of root diseases which the author says are divided in two groups. Group I is Marasmius sacchari; group II is Odontia sacchari, 0 . saccharicola and Himantia stollifera. The author also discusses the factor influeneing these diseases.

Mosaic or mottling diseases. Agric. News (Barbados) 19:245, 1920. 
Red ring disease of coconuts. Agric. News (Barbados) 18: 398, 1919.

This note is an extract from Nowell's report in Trinidad. Oct. 16, 1919. The disease is caused by nematodes.

Root rot disease of cacao. Jamaica Agric. Soc. Journ. 24: 173$174,1920$.

A note on the mosalic disease of sugar cane. Agric. News 19: $366,1920$.

A diseussion which refers to Stevenson article in Journ. Dept. Agric. Porto Rico. July 19, 1920.

A new method of selecting cane free of the mosaic disease for planting. Agric. News (Barbados) 19:363, 1920.

A note based on Edgerton's paper in La. Planter \& Sugar Mfg. Oet. 1920 .

Control of nematodes. Agric. News (Barbados) 9:367, 1920.

This note refers to a paper by Cobb in Science, June 1920 and suggests the introduction of promising species of monochs.

Mosaic disease of sugar cane. Agric. News (Barbados) 9:222, 1920.

This note refers to a paper by Brandes in Journ. Agrie. Res. May 1,1920 .

The Panama disease of banana. Agric. News (Barbados) 19:62, 94, 1920.

A discussion of paper by Brandes in Phytopathology. Sept. 1919.

Mosaic disease of sugar cane. Agric. News (Barbados) 19:158, 1920.

Refers to the Report of the Commissioner of Agriculture and Labor of Puerto Rico, 1919.

Mosaic disease of sugar-cane in Trinidad. Agric. News (Barbados) 19:126, 1920 .

A report of the disease in Trinidad. Had been there at least two years.

The wither-tip of limes. Journ. Bd. Agric. British Guiana. $13: 24,25,1920$.

The disease is caused by Gloeosporium limetticolum. 
Diseases of economic plants. West Indian Bulletin 18:50-60, 1920.

Records and geographieal distribution in the West Indies.

Mosaic diseases-susceptible and immune varieties. Journ. Jamaica Agric. Soc. 25:427-429, 1921.

The mosaic disease of sugar cane in Trinidad. Int. Sug. Journ. $23: 74-75,1921$.

Coffee Diseases. Bull. Agric. Com. \& Obras Pub. (S. Paulo) 22 : $330-332,1921$.

Diseases of Liberian cotfee in Surinam. Agr. News (Barbados) $20: 126,1921$.

Molestias em caffezaes (Diseases in coffee groves) Bul. Agr. S. Paulo. 22(12) : 330-332, 1921.

Report of a disease found on coffee in the distriet of Piratininga (Brazil). It was found associated with the fungi; Alternaria temuis, Phomos sp. and Fusarinm sp.

Diseases of economic plants. West Indian Bull. 19:31-37, 257, $271,1921$.

List of diseases and geographical distribution.

Mosaic disease in Barbados. Agric. News (Barbados) 20:15, 1921.

J. R. Bovell announces first appearance of the disease.

Relation between cacao pod rot and coconut bud rot. Agric. News (Barbados) 20:318, 1921.

La siembra del trigo y los tratamientos de la semilla. (Wheat seeding and seed treatment) Defensa Agric. Uruguay) 2: $89-98,1921$.

Treatment of whent for bunt-Tilletia.

Second rapport de la Station Agronomique de la Guadeloupe, 1919-20: 21-22, 35-42, 1921.

Reports Marasmius sachari on sugar eane.

Panama disease. Journ. Jamaica Agric. Soc. 26 : 454-456, 1922.

This discase which is due to Fusarium cubense first appeared in Panama in 1911. 
270 THE JOURNAL OF AGRICULTURE OF THE UNIVERSITY OF $P$. $k$.

Cocoe rot. Journ. Jamaica Agric. Soc. 26(2-3) : 62-54, 1922.

A discussion of the parasitism of Hormiseium colocasiae. He quotes a report by Ashby (1912) who gives the name H. xanthosomae n. sp. which be later change to Vasculomyces xanthosomae.

Report on the Agricultural Department, St. Lucía, 1921. Imper. Dept. Agric. West Indies. 1922.

Includes a report by Ashby on Fusarium cubense.

Ecuador Cacao disease. Bull. Pan. American Union 55:393, 1922.

Report of a commission of planters. The local name is "escoba de brujas" meaning witches' broom.

Notes on the proclaimed diseases and pests. Bull. Dept. Agric. Trinidad \& Tobago. 19(4) : 175-180, 1922.

Popular. Refers to bud rot of coconut, red ring disease of coconut, Anthracnose (blossom-blight and wither-tip) of limes.

Transmission of Sugar-cane mosaic by aphids. West Indian Committee. Circ. 37:521, 1922.

Report of the Dept. of Agriculture, Barbados, for the financial year 1921-22: 19, 1922 (Rev. Appl. Mycol. 2: 260-261, 1922).

Verslag over het jaar 1922 Department van Landbouw in Suriname. (Report of the Department of Agriculture, Suriname, for the year 1922,) p. 106, 1923.

Sugar and Mosaic disease of canes. Journ. Jamaica Agric. Soc. 27 : 864-869, 1923.

A popular review of the subject. 
Chile: Sanitäre Pfianzenschutzmassnak-men. Gesetz No. 177 vom 31. December 1934. In Auszug. (Chile, Sanitary plant protection measures. Order No. 177 of 31 st. December 1924.) Quarantine regulations.

Nicaragua: Reported cure for banana disease. Bull. Pan- American Union $58: 299,1924$.

Banana diseases. Journ. Jamaica Agric. Soc. 28: 247-248, 1924. A preliminary report on the prevalence of the Panama disease in Jamaica.

La enfermedad de la hoja del tomate. (Tomato leaf disease.) Defensa Agrícola (Uruguay) 5:17-23, 1924.

Symptoms, life history and control of Septoria Lycopersici.

Work in connection with insect and fungus pests and their control, Rept. Agric. Dept. (Antigua), 1922-23: 7-8, 1924.

Report on the Department of Science and Agriculture, British Guiana, for the year 1922, 45 p., 1924.

Reports bud rot of the coconut, witches' broom of the cacao ( $\mathrm{Ma}$ rasmius pernicious), Marasmius sp. of sugar cane, collar rot and knot of citrus and Colletotrichum falcatum on Andropogon sorghum sudanense.

El cáncer del peral (Pear canker.) Defensa Agrícola (Uruguay) $5: 25-26,1924$.

Canker caused by Monilia sp. Said to be distinct from Sclerotinia (Monilia) fructigena.

Desarrollo de las enfermedades de origen criptogámica en la viña, durante la presente estación. (Development of cryptogamic vine diseases during the present season.) Defensa Agrícola (Uruguay) 5:1-13, 1924.

Spraying for the diseases of the grape.

Antracnosis de la vid. (Gloeosporihm ampelophagum de Bary). Anthracnose of the Vine (Gloeosporium ampelophagum de Bary.) Min. Agric. Nac. (Buenos Aires), Sec. Prop. e Inform. Circ. 201, 4 p., 1924.

A description and recommendations for treatment.

La viruela de los frutales ("Small pox" of fruit trees Coryneum Beijerinkii Oud.) Argentina Min. Agric. 341, 4 p., 1924.

Brief popular account of this disease. 
THE JOURNAL OF AGRICULTURE OF THE UNIVERSITY OF P. R.

La viruela de los firutales de corozo. " "Small pox" of the trees of stone fruits.) Argentina Mins. Agric. 345, 8 p., 1924.

La gomosis del naranjo (Gummosis of the orange tree.) Argentina Mins. Agric. 339, 4 p., 1924.

Brief popular account of this disease.

Regulations against banana disease in Jamaica. Rev. of Appli. Mycol. 3: 64, 1924.

Dominican Republic. Protection against plant diseases. Bull. Pan-Amer. Union 56:1261-1262, 1925.

An official order.

Mosaic disease inspection. Rept. Dept. Agric. (Barbados) $1924-25: 8,1925$.

Work connected with insect and fungus pests and their control. Rept. Agric. Dept. St. Vincent for the year 1924: 16-25, 1925.

Mentions Sclcrotium rolfsii, Ovulariopsis gossypii and Phytophthora sp. on cotton. Marasmins sachari, Melanconium sacchari, Thielaviopsis paradoxa on sugar eane. Pucoinia arachitis on peanuts and Ustilago Zeae on corn.

El Dr. Cross y el mosaico de la caña en Cuba. (Dr. Cross and Mosaic disease of sugar cane in Cuba.) Rev. Agric. Com. \& Trab. (Cuba) 7(3): 10-11, 1924.

Controversial.

Experimental Agrieulture in Jamaica. Int. Sugar. Journ. 26: $274-276,1924$.

Terslag over het jaar 1923. Dept. van Landbouw in Suriname, 114 p., 1924.

Tlis report contains information about the sieve tulses (Phloem. necrosis) of coffee trees and probable insects carriers.

The mosaic disease of Sugar cane Order, 1923. Journ. Jamaica Agric. Soc. $28: 27,1924$.

Mosaic cane disease in América. Australian Sugar Journ. 16: $420,1924$.

Tratamiento eficaz para combatir la "fumagina" de la manzana "cara sucia". (Successfull treatment to fight "soot" of the apple "cara sucia") Argentina Circ. 468, 7 p., 1925.

Brief popular account on this subject. 
Plant diseases law (Law 10 of 1925). Journ. Jamaica Agric. Soc. 29(7): 267-280, 1925.

Mosaic disease. Trop. Agric. (Trinidad) 2:30, 1925.

A review of Rosenfeld's paper "The beneficial aspect of msoaic disease."

Mosaic disease. Journ. Jamaica Agric. Soc. 29:81, 1925.

A brief note containings lists of suseeptible losts.

Mosaic disease inspection, Barbados Dept. Agrie. Ann. Rpt. $1924-25: 8,1925$.

A record of inspection for sugar cane mosaic.

EI mosaico en Cuba. (Mosaic disease in Cuba.) Cuba, Rev. Agric. Com. Trab. 7(8): 23-25, 1925.

Mosaikkrankheit auf Kuba. (Mosaic disease in Cuba.) Deutsche, Zucker-industrie 50 : 1246, 1925.

Work in Connection with insect and fungus pests and their control. Antigua Dept. Agric. Report 1922-23:7-8, 1924. (Rev. Appl. Mycol. 4:59-60, 1925.)

Research on ctiseases of plants (mosaic) Trop. Agric. (T'rinidad) $2: 200,1925$.

Mosaic disease of sugar cane. Journ. Jamaica Agric. Soc. 29 : 144, 1925.

Enfermedad del mosaico. Extracto del Informe de la Comisión de Matanzas. (Mosaic disease. Summary of the Matanzas Commission Report.) Rev. Agric. Com. \& Trab. Cuba 7(8): $25-27,1925$.

Mosaic disease. Jamaica Dept. Agric. Ann. Rpt. 1925.

Work in comnection with insect and fungus pests and their control. Report Agric. Dept. St. Kitts-Nevis 1923-24: 5, 33, 1925. (Rev. Appl. Mycol. 4(11): 704, 1926.)

La enfermedad de la raíz del café en los semilleros. (Reproducción de la Hacienda, Veneznela.) (Coffee root disease in the seed beds.) Rev. Agric. Puerto Rico. 17(2): 18, 1926.

Mosaic disease in Jamaica. Sugar 28(1) : 30, 1926.

A review of circular issued by the Department of Agriculture of Jamaica. 


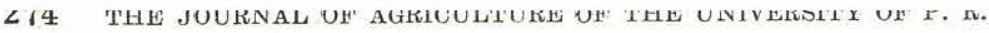

Mosaic da canna de assucar. (Sugar-cane mosaic) Min. Agric. Indus. Com. Inst. Biol. Defensa Agric. Río de Janeiro (Brazil) Cire. Serv. Phytp. 11 p., 1926.

Results of cane selection in Porto Rico. (Introduction of improved varieties credited with increasing annual value of crop by $\$ 13,000,000$.) Facts About Sugar 21(40): 950, 1926.

Popular.

Verrugas de la vid. (Vine wart.) Argentina Mins. Agric. Circ. 484, 4 p., 1925.

Brief account of a bacterial disease; preventive and curative measures are given.

La verruga de la viña. (Crown gall of the vine.) Min. Agric. Nac. (Buenos Aires). Sec. Prop. e Inform. Circ. 565(3): $1,1926$.

The causal organism in Bacterium tumefaciens.

The protection from plant disease (Banana trash) order 1926. Journ. Jamaica Agric. Soc. 30(10): 434-435, 1926.

Annual Report of the Jamaica Department of Agriculture for the year ending Dec. 31, 1926. 29 p., 1926.

Fusarium cubense is mentioned.

Work connected with insect and fungus pests and their control. Rept. Agric. Dept. St. Vincent (West Indies) for the year $1925: 13-18,1926$.

Contains records of several common diseases.

Mycological work. Rept. of Agric. Barbados, 1925-26: 10, 1926. A report on Sclerotium rolfsii causing a wilting of artichoke.

Brazil: Legislative and administrative measures. Internat. Bull. of Plant Protection 1(1): 11, 1927.

Decreto que prohibe la entrada de la papa extranjera atacada por plagas (Decree prohibiting the entry from abroad of potatoes atacked by pests and diseases.) Bol. Mins. Offic. Def. Agr. Estados Unidos Mexicanos 1(2): 66-69, 1927.

Foreign Quarantine No. 7. Bol. Mens. Ofic. Def. Agric. Estados Unidos Mexicanos 1(7) : 536-537, 1927.

A quarantine regulation. 
Algunas plagas de los frutales. (Some pests of fruit trees.) Argentine, Mins. Agric. No. 721, 14 p., 1927.

Brief notes on some fruit-tree diseases giving formulas for spraying.

La production du cacao d l' Ecuateur. (Marasmius perniciosus) (Cacao production in Ecuador) Agron. Colon. 16:173-174, 1927.

Algunas plagas de las hortalizas: (Some pests of the vegetable garden.) Argentina Mins. Agric. No. 720, 8 p., 1927.

Brief notes on some vegetable garden diseases giving formulas for spraying.

The selection of sugar-cane varieties for planting purposes. Planter and Sugar Manuf. 81(13): 246-247, 1928.

This note is based on a paper by Earle in the 1928 Reference Book of the Sugar Industry of the World. Contains brief reference to diseases.

Hexenbesenkrankheit in Trinidad. (Witchs' broom disease in Trinidad.) Tropenpflanzer 31:416-417, 1928.

Discussion on witch broom disease. Proc. Agric. Soc. Trinidad \& Tobago. 28:318-320, 1928.

Enfermedad de las naranjas. (Diseases of oranges). Bol. Agric. Indust. \& Com. (Guatemala) 4(5):159-160, 1928.

Refers to gummosis.

Ground nut rosette disease. Trop. Agric. (Trinidad) 6:111, 1929.

Quoted from Nature 122: 938, 1929.

Cacao notes. The relation between diseased cushions and the seasonal outbreak of black pod disease of cacao. Trop. Agric. (Trinidad) 6:295, 1929.

Informe de las actividades de la oficina general para la defensa agrícola. (Report on the work of the Federal Office for Agricultural defense.) Bol. Mens. Offic. Def. Agric. México 3: 237-239, 457-483, 1929.

Plagas y enfermedades de las plantas de cultivo interceptadas por el Servicio de Sanidad de los Estados Unidos durante el año de 1928, procedentes de México. (Diseases and pests of cultivated plants reported from México by the United States Quaraniine Service during the year 1928.) Bol. Mens. Off. Def. Agric. (México) 3:439-443, 1929. 
LIO 'IHE JUUKNAL UH' AGKIUULI'UKE UN' 'IHE UNIVEKSIIY UH'

Gummosis in Barbados. Trop. Agric. (Trinidad) 6(12):340. 1929.

A note stating that Dr. Briton-Jones has recently found this disease of cane (Bacterium vascularum) in Barbados.

O'mal da Panamá nos bananaes do Ecuador, Conselyos para debellar o' mal da Panamá. (The Panamá disease in the banana plantations of Ecuador. Recommendations for the control of the Panamá disease.) Bol. de Agric. Sao Paulo, Ser. 30a, (3-4) : 278-281, 1929.

This paper refers to Fusarium cubense.

Legislative and Administrative Measures. Argentina. Internat. Bull. of Plant Protect. 3(4):56, 1929.

Witchs' broom control 1929. Progress report (December).Proc. Agric. Soc. Trinidad \& Tobago, 30(1) : 15-16, 1930.

Attributes the disease to Marasmius pernicosus.

The Panama disease of bananas Amendment Order 1931, Under Section 3 of the Protection from Diseases (Plants) Law 1925, Law 10 of 1925, Dept. of Sci. and Agric. Jamaica 2 p., 1931.

Panama disease. Also Bonnygate (Sphaerostilbe musarum), black spot (Cescospora musarum) and Marasmius.

Mycological notes. Trop. Agric. (Trinidad) 7(11) : 309, 1930.

This note refers to a paper by J. Eaton and R. G. Fullerton on the effect of damp storage of a raw rubber. The author isolated three species of Penicillum (one of which was probably $P$. luteum), four species of Aspergillus (probably A. orchraceus, A. temeus, A. higer and A. versicolor) and a black Torula.

La "mancha de hierro" del cafeto. (The "iron stain" of the coffee trees.) Rev. Cafetera de Colombia 3(28-29): 10651068, 1931.

Popular article reproduced from "La Hacienda". This is the answer to an inquire made to the Experiment Station, Río Piedras, P. R. The disease deseribed is eaused by the fungus Stilbella flavida. The author gives as additional host plants of the fungus the following: oranges, mango, begonia, several ferns, Commelina sp., Inga Inga and Cissus sicyoides. 
Principales plagas y enfermedades de los cultivos en la República Mexicana inchnyendo las más importantes de Ios Estados Unidos de Norte América. (Principal cliseases and pests of cultivated crops in the Mexican Republic including the most important of United States of North America.) Tacubaya, D. F. Sec. Agric. \& Fomento, MLéxico 378 p., 1931.

Work connected with fungus and insect pests and their control. St. Kitts-Nevis, Dept. Agric. Rpt. 1931: 6, 1932.

Work connected with fungus and insect pest and their control. T'omatoes. St. Vincent Dept. Agric. Ann. Rpt. 1931:9-10, 1932.

El mal de Panamá. Enfermedad vascular de la planta del plátano. (Panamá disease. Vascular disease of the banana plant.) Sec. de Agric. y Fomento. Oficina para la defensaAgr. Boletín de Divulgación Núm. 15, Estados Unidos Mexicanos, (México), 1932.

A very complete discussion with methods of control and legislation.

Administration Report of the Director of Agriculture, Trinidad and Tobago for the year 1932, 58 p., 1933.

A lengthy discussion of the witchs' broom of eacio caused by Hid. rasmins perniciosus and a reference to Glocosporium limetticolum on limes.

Varietal introduction in Puerto Rico and Philíppines. Intern. Sugar Journ. 35(415) : 257-258, 1933.

Brief review of a lecture by C. E. Chardón and a paper by J. J. Mirasol on the effect of the introduction of immune or resistant sugar cane varieties to mosaic disease in Puerto Rico and the Plitippine Islands respectively.

Desmusgue. Rev. Cafetera de Colombia. 5(48-50): 1675, 1933.

The Panama disease amendment Order 1934, Journ. Jamaica Agrie. Soc. 38(9) : 573, 1934.

Legislation.

Report on the Agricultural Department, St. Kitts-Nevis, for the year ended 31st. December, 1933. Trinidad, Imper. Comm. Agric., West Indies, 49 p., 1934.

In this report (page 38 ) information is given as to the present situation regarding gumming lisease of sugar eane, which is present in most of the cane fields. No mosaic disease has been reported so far. 
The Panama disease of bananas. Amendment Order 1934. Journ. Jamaica Agric. Soc. 38(9) : 573, 1934.

Report on diseases and pests for the months of May and June, 1934. Proc. Agric. Soc. Trinidad and Tobago, 35(7) : 283284, 1934.

Brief note on witch's broom disease of eacao.

Enfermedades más comunes de las plantas cultivadas. (Prevalent diseases of cultivated plants). Min. Hacienda. Entre Ríos, Argentina, Dept. Agric. Gan: Bull. 7 p., 1935.

Popular account on some well-known fungal and bacterial diseases in Argentina. Control measures are suggested.

Panama diseases of banana. Journ. Jamaica Agric. Soc. 39 (1) : $30,1935$.

Account of a report of the Director of the Agricultural Soc. calling attention to the spread of Panama disease of banana in Jamaica.

Diseases and pests of the Bermuda cedar. Agric. Bull. Bermuda $14(12): 93-95,1935$.

Brief notes on cedar (Juniperus Bermudiana) diseases.

\section{Arango, $\mathbf{R}[$ odolfo]}

La enfermedad de las rayas amarillas, o mosaico de la caña de azúcar. (The yellow stripe disease or mosaic of sugar cane.) La Haciênda 16(4) : 106-109, 1921.

A popular discussion of the subject.

Archibald, R. G.

The castor oil plant (Ricinus communis). Trop. Agric. (Trinidad) 4(7) :124-125, 1927.

A description of a disease caused by Phytomonas ricini.

\section{Arnaud, G[abriel]}

Les Asterinées. Tese No. 1598, Fac. Sci. Paris 1918, 288 p., 1918.

\section{Arndt, C. H. \& Steiner, G.}

Aphelenchus parietinus as the cause of seedling losses in cotton. U.S.D.A. Plant Disease Reporter 15(8) : 82, 83, 1931.

Arthand-Berthet, J. et al

A saude dos eafezaes. (The health of coffee groves.) Bol. Agr. Sec. Agr. Com. \& Obras Pub. (Brazil) 13(9-12) : 809-831, 1912.

In this report are given the results of observations made in different plantations of coffee. Among the non-parasitic diseases con- 
sidered are: cold, heat moisture, wind, wounds, the soil and fire. Among the parasitic diseases are the fungi; Cercospora coffeicola Berk. \& Cooke, Stilbum flavidum, Corticium Zimmermannii Saac., Ros. trella coffeae Zimm. The animal parasites are also considered. Suggestion for control and prevention are given.

\section{Arthur, J[oseph] C[harles]}

Leguminous rusts from México. Bot. Gaz. 39: 385-396, 1905.

Rusts on compositae from México. Bot. Gaz. 40:196-208, 1905.

Uredinales. North Amer. Flora. $7: 83-160,1907.7: 161-268$, 1912.

Uredinales of Porto Rico based on collections by Fi. L. Stevens. Mycologia $7(4): 168-196$ (5) : 227-255, (6) : 315-332, 1915; $8(1): 16-33,1916$.

\section{\& Johnston, $J$ [ohn] $\mathrm{R}$ [obert]}

Uredinales of Cuba. Mem. Torrey Bot. Club. 17: 97-175, 1917.

Uredinales of Porto Rico based on collections by H. H. Whetzel and E. W. Olive. Mycologia $9(2): 55-104,1917$.

Rusts of the West Indies. 'Torreya 17:24-27, 1917.

Uredinales of the Andes, based on collection by Dr. and Mrs. Rose. Bot. Gaz. 65: 460-474, 1918.

Uredinales of Guatemala based on colections by E. W. D. Holway. Amer. Journ. Bot. 5(6) : 325-336, (8) : 420-446, (9) : $462-489,(10): 552-550,1918$.

Uredinales of Costa Rica based on colections of E. ஷ். D. Holway. Mycologia 10(3): 111-154, 1918.

Uredinales collected by $\mathrm{R}$. Thaxter and J. B. Rorer in Trinidad. Bot. Gaz. 73(1) : 58-69, 1922.

This report includes 43 species of rust fungi including a new genera and few now species, giving hosts plants.

Uredinales collected by Fred J. Seaver in Trinidad. Mycologia $14(1): 12-24,1922$.

Las royas de los regetales (Uredinales) del Perú. (The vegetable rusts (Uredinales.) of Perú.) Bol. Estac. Expt. Agric, Soc. Nac. Agra. Lima No. 2, 14 p., 1929.

New genera and species of Uredinales. Bull. Torrey Bot. Club. $60(7): 475-476,1933$. 
280 THE JOURNAL OF AGRICULTURE OF THE UNIVERSTTY OF P. R.

Nomenclatural priority in the Uredinales. Journ. Arnold Arbor $15: 263-265,1934$.

\section{Ashby, S[ydney] $\mathbf{F}[$ rancis]}

Banana diseases in Jamaica. Bull. Dept. Agric. Jamaica 2(6): 95-155, 1913.

A deseription of Panama disease and results of studies; black spot (Corcospora sp.,) Pestalozzia fuscens var. sacchari Walker and Acremoniella occulta Cawar; Bonny gate disease or banama wilt (Sphaerostibe musarum n. sp.); black head diseases (Thiclaviopsis paradoxa, Pythium or Lasiodiplodia theobromae; a dry bulb rot probably due to Terticillum sp.; Marasmius semiustis

Diseases of cocoa and other crops. Jamaica Dept. Agric. Bull. n. s. 2(6) : 150-155, 1913.

Brief notes on several erop plants occurring in Jamaica.

Notes on diseases of cultivated crops observed in 1913-1914. Bull. Dept. Agric. Jamaliea 2(8), 1915.

How to identify infectious plant diseases. Journ. Jamaica Agric. Soc. 20(1) : 6-12, 1916.

Annual Report of the Microbiologist 1916-17. Dept. Agric. Jamaica. Ann. Rpt. 1916-17: 28, 1917.

Leaf roll clisease of Irish potatoes. Jamaica Journ. Agric. Soc. $23: 44-46,1919$.

A comment on Wortley's paper (Plyytopathology 8:507-529, 1918.) The author recommends preventive methods specially rouguing.

Mottling or yellow stripe disease of sugar cane. Journ. Jamaica Agric. Soc. 23: 344-347, 1919.

A compiled account of the disease now prevalent in Porto Rico and southera United States. Description of damage, symptoms, distribation, variety attacked and control measures are given. The disease is not known in Jamaica.

Report of the microbiologist, 1918-19. Jamaica Bd. Agric. \& Dept. Pub. Gard. \& Plantations Ann. Rpt. 1918-19: 26, 1919.

Brief note on thrend blight of coffee caused by the fungus Pellicularia Koleroga.

Late blight of Irish potato. Journ. Jamaica Agric. Soc. 23: 10-16, 1919 .

Popular. 
Bud-rot disease of coconuts. Journ. Jamaica Agric. Soc. 22 : 331-333, 1919.

This is a discussion of Thielavionsis paradoxa and Phytophthora sp. The forms of the diseases are (1) pine-apple leaf bitten disease,

(2) hard or little leaf-bitten disease, (3) Phytophthora leaf-bitten disease and (4) Rhinoceros beetlo leaf-bitten disease.

Bud rot of coconuts. Journ. Jamaica Agrie. Soc. 23-23-25, 1919.

Recommends methods of control.

Report of the microbiologist, 1920. Ann. Rept. Dept. Agric. Jamaica, 1920 : 24-25, 1921.

Reports Panama disease of banana, bud rot of coconuts, leaf bito of coconut. Also the isolation of Rhizoctonia and Pythium from the roots of trees.

Notes on two diseases of the coco-nut palm in Jamaica caused by fungi of the genus Phytophthora. West Indian Bull. $18: 61-73,1920$.

A report of studies on Phytophthora palmivorum Butler and $P$. parasitica Dastur.

Leaf stalk caused by $P$. parasitica Dastur. West Indian Bull. $18: 70-73,1920$.

The mosaic, mottling or yellow stripe disease of sugar cane. Jamaica Dept. Agric. Leaflet 13 p., 1920.

Popular.

Diseases of plant-sugar cane. Jamaica Dept. Agric. Ann. Rpt. $1920: 26,1920$.

Brief reference to sugar-cane mosaic. First record in Jamaica.

A disease of Liberian coffee in Surinam. Agric. News (Barba$\operatorname{dos} 20(495): 126,1921$.

This note refers to Bull. 20 by Stahel, Surinam Dept. of Agric. March 1920. Oceurs on C. liberica and to some extent on C. arabica. Probably a virus disease but not recognized as such. The disease is described.

The mosaic disease of cane. Agric. News (Barbados) 20(496) $142,143,1921$.

This note refers to a bulletin on Mosaie, Mottling, or yellow-stripe disease of eane. Publislied by the Jamaica Dept. Agric. 1920. The symptoms are deseribed. 
Root disease of sugar cane. Agric. News (Barbados) 20:158$159,1921$.

A note based partly on other publications.

Relation between eacao pod rot and coconut bud rot. Agric. News (Barbados) 20(507): 318, 1921.

Stem-end rot of citrus fruits during shipments. Agric. News (Barbados) $20: 334$, 335, 1921.

This note refers to the Agricultural Extension Notes from the Porto Rico Agricultural Ept. Sta. in which Henricksen states that there are rots due to Diplodia natalensis which may be the common wound parasite Lasiodiplodia (Diplodia) theobromae.

Some recent observations on red ring diseases of the coconut. Agric. News (Barbados) 20:350, 351, 1921.

This note gives the results of infection experiments.

Some recent observations on red disease of the coconut, Agric. News (Barbados) $20: 334,1921$.

A study of the nematode causing this disease.

Resort on the Agric. Dept. St. Lucia, Imp. Dept. Agric. West Indies, 31 p., 1922.

Bud-rots of the coconut palm in West Indies. Proc. Imp. Bot. Conference 1922 : 153-158, 1922.

Oospores in cultures of Phytophthora faberi. Kew Bull. Misc. Infor. 9: 257-262, 1922.

A discussion of this fungus which attacks cacao in the West Indies.

A fungous decay of nutmegs in Grenada. Agric. News (Barbados) 21:519 p. 93, 1922.

This disease of nut meg (Muristica fragrans) is apparently due to a Phomopsis.

Experiments or red ring disease of the coconut in Grenada. Agric. News (Barbados) 21: 94, 1922.

A case of a simple cure. Trop. Agric. (Trinidad) 1(4):6263, 1924.

A review of Dr. Wilbrink's paper in Arch. Java Suikerindus. 1: 1923 . 
Bananas resistant to wilt (Panama disease) Trop. Agric. (Trinidad) 1 (11) : 172-173, 1924.

A brief reference to the disease and the possibilities of a resistant variety.

Three serious cane diseases not yet reported from the British West Indies. Proc. Ninth West Indian Agrie. Conf. p. 84-89, 1925.

Obscure plant diseases of widespread occurrence. Sugar cane mosaic. Report of Proc. Imp. Conf. London, p. 122-131, 1924. (Rev. Appl. Nycol. 4(7) : 442, 1925.)

Seed-borne diseases. Trop. Agric. (Trinidad) 2(1):8-9, 1925. A general discussion.

Researches on Panama Disease. Proc. 9th West Indian Agric. Conf. 1924: 51-53, 1925.

A diseussion of work. At one time believed the disease might be due to some cause other than Fusarium cubense.

Bud-rots of the coconut palm in the West Indies. Rept. Imper. Bot. Conf. London, 1924: 153-158, 1925.

Refers mostly to Phytophthora palmivora.

Withertip and blossom blight of limes. Proc. Ninth West Indian Agric. Con. 1924:172-174, 1925.

Refers to Colletotrichum gloeosporioides and Glocosporium limetticolum,

Mycological notes. Selection of sugar-cane in Louisiana for tolerance to mosaic disease. Trop. Agric. (Trinidad) 2(7): $150,1925$.

A review of a paper in Planter and Sugar Mannfacturer by Edgerton \& Taggart.

The perfect form of Stilbum flavidum Cle. in pure culture. Kew Bull. Mis. Inf. 1925(8) : 325-328, 1925.

The material was from Trinidad. It developed a stage conform. ing to Maublane \& Rangels description of Amphalia flavida. Also refers to synonyms.

\section{\& Nowell, W[iliam]}

The fungi of strigmatomycosis. Anm. Bot. 40(157):69-83, 1926.

Nowell described four strains of Nematospora. Ashby described them as (1) Spermophythora gossypii n. sp. on lint of cotton, in tomato fruits and in seeds of cow peas. (2) Eremothecium cym- 
balariae Borzi in eotton bolls and tomato fruits. (3) Nematospora gossypii n. sp. on the lint of cotton and seeds of Datura metel and Asclepias curassavica. (4) Nemathospora coryti Peglion.

Behavior of some varieties of cane to mosaic disease in the Hawaiin Islands. Trop. Agrei. (Trinidad) 2(6) : 132-134, 1925. (Rev. Appl. Mycology 5(1):3, 1926.)

A review.

A wilt disease of bananas. Trop. Agric. (Trinidad) 3(6) : 127129, 1926.

The author reports successful corn inoculations to tomato and tobacco. This disease was reported by Rorer in 1910 and 1911 .

Mycological Notes. Trop. Agric. (Trinidad) 3(8-9) : 50-51, 71, 98, 1926.

Brief discussion of the angular leaf spot of cotton (Bacterium malvacearum E. F. Smith), gumming diseases of sugar cane (B. vascularum E. F. S.), bunchy top disease of banana (based on studies in the east), and red stripe (Phytomonas rubrilineans Lee et al) of sugar cane (based on work in Hawaii).

Gumming disease of sugar cane in the British West Indies. Trop. Agric. (Trinidad) 3(3):50-51, 1926.

Review of Matz's work in Puerto Rico and discussion of symptoms and distribution.

Mentions the finding of gummosis of sugar cane in St. Kitts and St. Lucia.

Bacterial wilt disease of bananas. Kew Bull. Misc. Inform. 1927 (1) : 14-18, 1927.

The organism was obtained from bananas in Trinidad and inoculated into tomato and tobaceo plants. It produced symptoms and has eultural characters of Bacterium solanacearum.

The oospores of Phytophthora nicotianae Br. de Haan, with notes on the taxonomy of P. parasitica Dastur. Trans. Brit. Mycol. Soc. 18(1-2) : 86-95, 1928.

These studies were based on material obtained from the Dutch East Indies, Florida and Trinidad.

The bacterial wilt of bananas and plantains. Agric. Journ. Brit. Guiana 1(4) : 217-220, 1928.

A description of the disease which is attributed to Bacterium solanacearum E. F. S. Also a discussion of the organism and methods for control. 
Diseases of limes and sugar cane in West Indies. Kew Bull. Mise. Inf. 1929(7) : 209-214, 1929.

Reports Gloeosporium limetticolum on limes in several islands and Bacterium vascularum on purple transparent, Caledonia Queen in Dominica and on $\mathrm{Ba} 11569$ in Antigua.

Notes on two diseases of coconut palm in Jamaica caused by fungi of the genus Phytophthora. West Indian Bull. 18 $(1-2): 61-72,1920$.

Gumming clisease of sugar cane. Tropical Agric. (Trinidad) $6(5): 135-138,1929$.

This paper gives the results of studies on Bacteriam vascularum (Cobb) J. F. Sm. and of two other bacterial diseases of sugar cane.

Gloeosportum strains. Trop. Agric. (Trinidad) 8(12) : 322-325, 1931 .

This is a study of 32 strains isolated from bananas in Trinidad.

\section{Averna-Saccá, Rosario}

A Brusca. Contribucao para o estudo desta doenca em algunas plantas tropicaes e exoticas cultivadas no Estado de Sao Paulo. (La "Brusca", Contribution to the study of this disease in some tropical and exotic plants cultivated in the State of San Paulo.) Bol. Agric. Sec. Agric. Com. e Obras Pub. S. Paulo 12(8) : 557-609, 1911.

A rather extensive, detailed work deseribing a disease of coffee which also attacks olives, eacao, almonds and other plants. The author believes it to be due to a physiological disturbance caused by low or high temperatures during the growing period of the plant. If the change is rapid and of short duration falling of the foliage occur's; but if the ehange is prolonged, death of the branches occurs. On the affected leaves and twigs several species of fungi are found but no one is the causal agent of the disease, therefore the author regards them as secondary.

Molestias eryotogámicas do caféeiro. (Cryptogamic diseases of the coffee tree.) Bol. Agric. Sec. Agric. Com. \& Obras Pub. (S. Paulo) 17(10):790-840, (11):878-922, 1916.

This is a systematic study of best known or reported diseases of coffee in Brazil caused by fungi. Gives descriptions of damage caused by each organism as well of the deseription of each one and is very well illustrated.

Podridao das raízes do caféeiro, producida por una forma de mycelio esteril. (Rotting of the coffee roots caused by a sterile form of a mycelium.) Bol. Agric. Sec. Agric. Com. \& Obras Pub. (S. Paulo) 18(5) : 376-380, 1917. 
Description of a disease observed on the coffee tree and reported in 1914 and 1917. The supposed eausal agent of the rottening of the coffee roots is the fungus Dematophora necatrix or a Dendrophoma. The author is inclined to believe that it is identical to the fungus described by D'Herelle from Honduras Phthora vastatrix.

Molestias das laranjeira. (Diseases of the orange.) Bol. Agr. Sao Paulo. Ser. 18:334-346, 1917.

Molestias encontradas sobre as folhas do fumo de gergelim provenientes de Soccono (Pernambuco) remettidas pela directoria de agricultura. (Foliage diseases of tobaceo and gergelim) Bol. Agric. Sao Paulo 18:984-986, 1917. (Bol. Agric. Sao Paulo, 19:70-71, 1918.)

A disease of tobacco caused by Cercospora solanicolum and of Sesamum indicum caused by Cercospora sp.

Exame microscopico das jaboticabas enviadas pela directoria de Agricultura. Ferrugem das aboticabeiras. (Rust jabotica) Bol. Agric. (Sao Paulo) 19:68-69, 1918.

Reports Uredo sp. on leaves of Myrciaria jaboticaba and methods of control.

Molestia das viderias (Diseases of grapes.) Bol. Agric. Sao Paulo 19: 214-220, 1918.

Lists Gloeosporium ampelophagum on Vitis rupestris du Lot and V. rupestris pautista. Also Gl. physalosphorae on Niagara grapes.

Molestias da macieria. (Disease of apple) Bol. Agric. (Sao Paulo) 19:430-433, 1918.

Reports diseases caused by Ascochyta sp. Pleospora herbarum and Sphaerella pomicola.

(Cryptogamic diseases of cacao and of coconut.) Bol. Agric. (Sao Paulo) 21(1-3):46-186, 1920.

Servico de insceccao e defesa agricola. Molestias do caféeiro. (Service of defense and plant inspection. Coffee diseases.) Bol. Agric. Sec. Agric. Comm. \& Obras Pub. (S. Paulo) 21: 4-5, 214-219, 1921.

Report on the disease causing rotting of the roots of the coffee tree. The author states that it is caused by the fungus Dematophora necatrix.

Molestias da videira (Diseases of the vine) Bol. de Agric. (Sao Paulo) Ser. 22(1-2):6-15, 1921.

Observation on Capnodium salicinum and Pestalozzia uvicola. 
Algunas das molestias cryptogamicas do tobaco. tabacum) (Some cryptogamic diseases of tobacco. (Nicotiana tabacum) Bol. Agric. Sec. Agric. Comm. \& Obras Pub. (S. Paulo) 23(7): 201-268, 1922.

Algunas das molestias eryptogámicas mais communs da baunilla (Vanilla planifolia) nos estados de $\mathrm{S}$. Paulo o $\mathrm{S}$. Catherina. (Some of the most common eryptogamic diseases of vanilla (Vanilla planifotia) in the States of S. Paulo and S. Catherine.) Bol. Agric. Sec. Agric. Com. \& Obras Pub. (S. Paulo) 23(9-10) : 282-305, 1922 .

Os gasteromycetes mais communs nas hortas nos pomares e nos campos. (The most common gasteromycetes in the vegetable gardens, orchards and fields.) Bol. Agric. Sec. Agric. Com. \& Obras Pub. (S. Paulo) 23(9-10):306-310, 1922.

Segunda contribucao para o estudo das moestias cryptogamicas do caféeiro. (Second contribution to the study of the cryptogamic diseases of coffee.) Sec. Agric. (S. Paulo) Ser. Pubi. 63 p., 1925.

Algunas das molestias cryptogamicas que atacan os fructos do cacauerio no littoral paulista. (Some of the cryptogamic diseases which attacks the cacao fruits in the $\mathrm{S}$. Paulo coast.) Bol. Agric. Sec. Agric. Com. \& Obras Pub. (S. Paulo) 26: $518-539,1925$.

As manifestacoes pathologicas que acompahan o desenvolvimiento da broca Stephanoderes hampeii, Ferr. (S. coffeae Hag.) nos frutos on nas sementes de cafeiro. (The pathological manifestations acompanying the development of Stephanoderes hampeii Ferr. (S. Coffeae Hag.) in the fruits and seeds of the coffee trees.) Com. de Eistudio de Debellacao da Praga Cafeira. Sec. Agr. Com. e Obras Pub. 15, 87 p., 1926.

Extensive and interesting work very well illustrated with diagrams in relation to the fungi that develop in the lesions of the coffee berries caused by the borer Stephanoderes hampei.

Contribuicao para o estudio das molestias cryptogamicas das roseivas (Fingous diseases of roses) Sec. Agric. Com. e Obras Publ. Estado Sao Paulo (Brasil) 67 p., 1926.

Deseriptions, symptoms and distributions of diseases of roses. $\Lambda$ lso the life histories of the fungi.

Algunas molestias cryptogamicas novas do systema radicular do caféeiro. (Some new cryptogamic diseases of the coffee root system.) Com. de Estudio e Debellacao da Praga Caféira. Sec. Agric. Com. \& Obras Pub. 17 p., 1926. 
In this paper the author considers in detail several diseases of the coffee roots. Among the diseases mentioned are those caused by the fungi, Stilbum radiciperda, Polyporus sp., Glomerella coffeicola f. Radicicola Averna, Colletotrichum radicicola, C. radiciperda, Fusarium heterosporium and other Fusaria.

Sobre a presenca de um protozoario nos tecidos da canna de assucar atacadas pelo "Mosaico". (On the presence of a protozoa in tissue of cane attacked by mosaic.) Bol. de Agric. Sao Paulo, (Brasil) 27 (8-9) : 183-204, 252-273, 303-319, 388$398,1926 ; 28: 173-182,1927$.

A histological study in which the author describes a protozoan living in diseased plants. The author believes this organism to be the causal agent.

Os entomophagos cryptogamicos na broca do caffeiro (Stephanoderes hampei Ferr.) encontrados en S. Paulo. (The entomogenous fungi of the coffee borer (Stephanoderes hampei, Ferr.) found in S. Paulo). Bol. Agric. Sec. Agric. Com. \& Obras Pub. Bol. Agric. S. Paulo. 31:10-24, 195-213, 1930.

Contribueao para o estudio da biologia da Thielaviopsis paradoxa (de Seynes) Höhn., da Bananeira e da canna de assucar e sua pretensa relacao com o Melanconium sacchari, Massee. (A contribution to the study of the biology of Thielaviopsis paradoxa (de Seynes) Höhn, from Banạna and sugar cane and its supposed relationship with Melanconium sacchari, Massee) Rev. Agric. (Brasil) 7(3-4) : 114-130, 1932.

A study of these two fungi in Brazil.

Um entomophago cryptogamic do Caconema radiciola (Greef) Cobb Fusarium mauroi n. sp. (A cryptogamic entomophage of Caconema radiciola (Greef) Cobb (Fusarium mauroi n. sp.) Rev. Agric. (Brasil), 8(3-4): 93-101, 1933.

A description of the nematode.

\section{Azevedo, H. De}

Estado sanitorio vegetal des Cacaoerios em Belmonte. (Sanitary status of the cacao groves in Belmonte.) Correiro-Agric. Bahia 3:249-252, 270-274, 1925.

Azevedo, $\mathbf{N}$.

Nota sobre um lichen perjudicial ao Guaco (Mikania scandens L.) (Notes on a licher injurious to "Guaco" Mikania scandens L.) Rodriguesia 1(3) : 33-34, 1935.

Report of a lichen (Strigula elegans F'ée \& Müll f. hirtella Müll Arg.) leaf infection of the medicinal plant known in Argentine as "Guaco", (Mikania scandens L.). Preventive measures are recommended. 
A "variola" do Namóéiro. (A "pox" of Carica Papaya). Rodriguesia 1(2): 91-93, 1935.

Deseription to a leaf spot of Carica Papaya (Asperisporium Cari$(a e)$. The perfect stage (IIycosphaerella Caricat) was found in the pericarp of the fruit. Control measures are suggested.

Nota sobre o "Diplodia" do Algodoeiro (Note on a Diplodia of cotton). Rodriguesia 1(2):97-98, 1935.

Report of the record of Diplodia gossypina on cotton bolls grown in experimental plots in Brazil during 1933.

Azzi, R.

Uma nova molestia da canna de assucar. (A new disease of sugar cane.) Bol. Agrie. (Sao Panlo) Ser. 28(9-10):526-532, 1927.

Refers to Fawcett's work on cold chlorosis of sugar cane.

\section{Báez, Horacio}

La rulla o polvillo de trigo (Wheat rust), Defensa Agric. (Uruguay) 3:163-167, 1922.

The disease is caused by Puccinia araminis tritiet.

Báez, J. R.

Criptogamas parásitas observadas en la Prov. de Entre Ríos, sobre las plantas cultivadas. (Parasitic eryptogams observed in the Prov of Entre Ríos. on cultivated plants.) Argentina Bol. Mins. Agrie. de la Nación. 26(1) : 3-21, 1921.

Record of several fungous diseases occurring in Entre Rios Prov. on eultivated plants.

Bain, F. 'M.

Bronz leaf wilt of the coconut palm. Agric. Soc. Trinidad and Tobago. $35(12): 507-521,1934$.

Popnlar.

Report on wilt disease of coconnts for 1934. Admin. Rep. Dir., Agric. Trimidad \& Tobago. 1934:50-51, 1935.

Baker, R. E. D.

Maize stripe clisease. Trop. Agric. (Trinidacl) 10(8):221, 1933.

A brief note with reference to the transmission of this disease by Peregrimus maidis.

Stripe disease of Maize. Trop. Agric. (Trinidad) 10(12) : 352, 1933.

A brief description. 
Papaw root and collar-rot. Trop. Agric. (Trinidad) 10(11): 328-329, 1933.

A description of the disease and experiments. Cause not definitely determined, but Botryodiplodia theobromae was found.

Root disease of lime in Monserrat. Trop. Agric. (Trinidad) $13(6): 147-148,1936$.

Although not considered primarily parasites the following organisms were obtained from branches and roots of lime trees affected with root disease and associated with attacks of Diaprepes larvae: Botryodiplodia Theobromae, Phomopsis (Diaporthe) Citri, and a Fusarium sp. Also Sphaerostilbe repens a weak parasitic fungus. Withertip (Gloeosporium limetticolum) has so far caused no serious losses, probably due to the dry elimate of the Island.

Notes on Trinidad fungi. I. Phytophthora. Trop. Agric. (Trinidad), 13(12) : 330-332, 1936.

Ballou, H. A.

Thrips and black blight. Trinidad Bot. Dept. Bull. Misc. Inform. 14 : 132-135, 1904.

Report on the prevalence of some pests and diseases. West Indian Bull. (Barbados) 13(4): 333, 1913.

Insect pests and plant diseases. West Indies Imp. Dept. Agric. Grenada Dept. Agric. Ann. Rpt. 1918-19:14-26, 1919.

Balls, W. L.

Notes on internal disease of cotton seed. Imperial Dept. of Agric. Agric. News (Barbados) 14:314, 1916.

Balmaseda, F. J.

Tesoro del Agricultor Cubano. 2nd. Edition. 2:154, 1893. A manual.

Bancroft, $\mathbf{C}$ [laude] $\mathbf{K}[$ eith]

New West Indian Cacao pod disease. West Indian Bull. 11: $34-35,1910$.

Description of a new species. Colletotricum Cradwicliii.

A handbook of the fungus diseases of West Indian Plants. London, 70 p., 1910.

Fungi eausing diseases of cultivated plants in the West Indies. West India Bull. 10(3) : 235-268, 1910.

A list of diseases with descriptions in most cases. 
A disease of the eacao plant. Roy. Bot. Gard. Kew, Bull. Mise. Inform 3: 93-95, 1910.

A note on the occurrence of Fomes semitostus in British Guiana. Jourrr. Bd. of Agric. British Guiana. 7(2):91, 1914.

A brief mention.

A fungus disease of pepper (Capsicum spp.). Journ. Bd. Agrie. British Guiana 1(3): 139-141, 1914.

The disease is described. It is attributed to Colletotrichum nigram E. $\& \mathrm{H}$.

Fungus notes. Journ. Bd. Rgric. Brit. Guiana. $7(3): 141$, 1914.

A leaf spot on an orehid (Phalaenopsis esmeralda, Regnerii is attributed to Uredo orchidis Wint. A mildew on rose is attributed to Sphacrotheca pomosa Lev.

A disease affecting the sisal hemp plant. Journ. Bd. Agric. British Guiana $7(4): 181-182,1914$.

The disease is caused by Colletotrichum agaves Cav. The symptoms are deseribed.

The "new disease" or "dry disease" of the sugar cane. Journ. Bd. Agrie. British Guiana. 7(4):183-187, 1914.

The disease is attributed to ILarasmius sacchari and symptoms are deseribed.

A leaf disease of Para rubber. Journal $\mathrm{Bd}$. Agric. British Guiana $7(1): 37-38,1913$.

Plant diseases in British Guiana. Brit. Guiana Dept. Sci. \& Agric. Ann. Rpt. 1914-15(2) : 7-10, 1915.

Report on the South American leaf disease of Para rubber. Journ. Bd. Agric. Brit. Guiana. 10:13-33, 1916.

The disease is attributed to Fusicladium macrosporm Kuyper (Aposphaeria Olei P. Henn. of Brazil). The symptoms of the disease described. The author also discusses a die back and root diseases caused by Fomes semitostus and Hymenochaete noxia.

The author also refers to two leaf spots in Brazil,-Dothidella rele P. Henn. \& Phyllachora buberi P. Henn. 
The leaf disease of rubber. Conditions in Suriname. Journ. Bd. Agric. Brit. Guiana. 10: 93-103, 1916.

This is the disease attributed by the author to Fusicladium macrosporum Kuyper. It has been described by Massee as Passalora heveae and by Stahel as Melanopsammopsis heveae. It attacks Heveae braziliensis, H. guyanensis and H. confusa.

The official gazette of British-Guyana. 41:374-379, 1916.

The mango and bread fruit disease. Journ. Board Agric. British Guiana. 11: 75, 1918.

The disease is caused by Gloeosporium mangiferae and the losses areheavy. Recomends spraying with Bordeaux mixture.

Diseases in plants with special reference to fungi parasitic on: crops in British Guiana. Journ. Bd. of Agric. Brit. Guiana. $11: 47-57,1918$.

A popular paper containing list of diseases known to occur in British Guiana.

\section{Barber C[hares] A[lfred]}

Report on diseases affecting the sugar cane in Barbados. St. John, 6 p., 1893.

The mosaic or mottling disease of sugar cane. The main facts of the case to date. Int. Sugar Journ. 23(265): 12-19, 1921.

A review of the studies on sugar-cane mosaic by Johnston, Grey, Edgerton, Earle, Fawcett, Stevenson and Brandes.

Root disease of the eane in Barbados. Intern. Sugar Journ. 25 : 514-518, 1923.

A review of the recent literature and of our knowledge of the subject.

La situación actual en relación con el matizado en Cuba. (The present position as regards mosaic in Cuba.) Rev. Agric. Puerto Rico. 13(4) : 265-272, 1924. (Int. Sugar Journ. 26. (309) : 469-473, 1924.

Experimental Agriculture in Jamaica. The Campaign against mosaic. Int. Sugar Journ. 26(309) : 474-476, 1924.

Account of the position of sugar-cane industry in Jamaica in regard to sugar-cane mosaic disease and campaign to erradicate it.

The Havana Conference on Cane diseases. Inter. Sugar Journ. $30(359): 575-582,1928$.

A record of the discussion on diseases of sugar-cane. The greater part of the discussion was devoted to mosaic disease of sugar cane.. 


\section{Bardales, IManuel A.}

Algunas enfermedades fungosas de los cafetales en Guatemala. (Some fungous diseases of the coffee grove in Guatemala.) Bol. Agr. \& Caminos, Guatemala. 7(9):433-436, (10) : 495499 , (11) : 543-546, 1928.

The author deseribes and gives methods for controlling the following diseases.

(1) Koleroga or "candelillo" caused by the fungus Corticium Koleroga.

(2) The leaf spot or "Iron stain" caused by the fungus Stilbella ftavida and

(3) The root disease of coffee caused by the fungus Itosellinia acuila.

Barker, A. C.

Report on failure of Cacao crop in Dominica. 1892-93, Supplement to Leeward Is. Gazette, April 27, p. 52, 1893.

Barker, H[enry] D.

Plant diseases and pests in Haiti. Int. Rev. of Sci. \& Prac. of Agr. S. S., 4(1) : 184-187, 1926. (Rev. of Appl. Mycology $5(9): 583,1926$.

Barkelay, J.

Banana diseases. Journ. Jamaica Agric. Soc. 16:90-92, 1912.

Barreto B[raulio] T.

Algo sobre la extirpación del matizado. (Facts on mosaic eradication.) Rev. Agric. Com. \& Trab. Cuba. 7(4):12-13, 1924. (Agricultura (Cuba) 2:8-9, 1924.)

La situaeión de la enfermedad "Mosaico" en la Provincia de Camagüey. (Mosaic disease situation in the province of $\mathrm{Ca}$ magüey.) Agricultura (Cuba) 1: 150, 152, 1925.

Barrett, Wary $\mathrm{F}^{2}$.

Three common species of Auricularia. Mycologia 2(1):12-18, 1910.

Barrett, o[tis] W[arren]

Fungus diseases. Puerto Rico Agric. Expt. Sta. Ann. Rpt. $1003: 449-450,1904$.

Notes on fungus diseases of octurence in Puerto Rico.

Diseases of Yautía. Puerto Rico Agric. Expt. Sta. Bull. 6:22$23,1905$.

Fungus diseases. Puerto Rico Agric. Expt. Sta. Ann. Rpt. 1904: 397-399, 1905.

Report of the Entomologist and Botanist. Puerto Rico Agric.

Expt. Sta. Ann. Rpt. 1905: 21-23, 1906. 
Notes upon miscellaneous crops. Proc. of the Agric. Soc. of Trinidad. $7: 303,1906$.

Cacao pests of Trinidad. Proc. Agric. Soc. Trinidad \& Tobago. $7(10): 281-304,1907$.

Barthe, A. E.

Una enfermedad del cacao. Rev. Agric. Santo Domingo. 6(5): 103-112, 1910.

Popular.

La oficina de Sanidad vegetal de la Secretaría de Agrieultura Comercio y Trabajo. Resumen de las plagas ya estudiadas $\mathrm{y}$ combatidas. (Review of the plagues so far studied and combatted.) Rev. Agrie. Com. \& Trab. (Cuba) 3:290, 292, 296, 1920.

A report on the bud rot of the coconut with recommendations for its control.

Bartlett, A. W.

Notes on some plant diseases. Brit. Guiana Bot. Gard. Ann. Rpt. 1906-07:20-22, 1907.

Brief notes on crop plant diseases.

Report on fungus diseases of cotton. Brit. Guiana Official Gazetie. March 13, 1907.

Baylis, H. A., \& Daubaney, $\mathbf{R}$.

A symopsis of the families and genera of Nematodes. London 1926.

An important paper for the study of nematodes.

Beaurepaire Aragao, Henrique de

Über Phytomonas Francai. Anhandlungen aus dem Gebiete der Auslandskunde. Hamburgesche Universitä, Bd. 26, Reihe D. Medicin, Bd. 2, Festschrift Prof. B. Nocht. (n. d.)

Sur un flagellé du latex de Manihot palmata: Phytomonas Francai n. sp. Compt. Rend. Soe. Biol. 97(27): 1927.

Pesquizas sobre Phytomonas francai-Untersuchungen über $P h y$ tomonas francai.) (This article is published in German and Portuguese.) Mem. Inst. Oswaldo Cruz (Brazil) 25(4) : 299306,1931 .

Beckett, Edgar.

Wilt disease of coconut palms in Trinidad. Part I. Agric. Journ. of Brit. Guiana. 1(2) : 127-128, 1908.

A review of Briton-Jones paper in Trop, Agric May, 1928. 
Beille, L.

(Diseases and enemies of cacao.) Journ. Agric. Trop. 13(144): 167-172, (145) : 193-197. (146):236-238, 1913.

Belgrave, W. N. C.

Notes on the South American leaf disease of rubber. British Guiana, Joum. Bd. Agric. 15:132-138, 1922.

This appears to be the same as an article in Agricultural Bulletin. Federated Malay States. The author refer to a paper by Staliel. Bull. No. 34. Jan. 1907, Dept. v. d. Landbouw in Surinam.

\section{Bell, A[rthur] F[rank $]$}

Cane diseases in Lotisiana and West Indies. Anstralian Sugar Journal. 18(10):601-607, 1927. (The Planter (Abstract) $78(8): 147-148,1927$.

The distribution of sugar-eane mosaic. Ref. Book Sugar Industry of the World. 7:31-32, 1929.

Report of the results of the observations made by the author during 1924-28, while visiting the most important sugar-cane producing centers.. Concludes by inserting a list of the seven major diseases of sugar eane with their geographical distribution.

Sugar-cane diseases of North America and the West Indies. Queensland Agric. Journ. 27(2):99-104, 1927.

Bell of Australia traveled througil the sugar cane region and published this report in whieh he mentioned several diseases.

\section{Benatora, $\boldsymbol{R}$.}

Fungos entomogenos dos Citris (Entomogenous fungi of Citrus). Rodriguesia 1(2): 7-10, 1935 .

Brief popular notes on the following entomogenous fungi found on Citrus, in Brazil: Aschersonia aleyroidis, which is very commonly parasitic on Aleyrodidae on orange leaves; $A$. goldiana which chiefiy attaeks Dialeurodes citrifoli; A. turbinata which attacks coecids; Sphoaerostilbe aurantiicola, S. flammea, S. coccidophthora, Podonectria cocicola, Myriangium duriaei and Septobasitium albidum which is abundantly present in most Citrus plantations in Brazil and may cause considerable damage by infecting large areas of the surface of the fruit near the peduncle.

\section{Berkeley, Miles Joseph.}

Enumeration of some fungi from Santo Domingo. Ann. Mag. Nat. Hist. II, 9.

Notices of some Brazilian fungi . . . being a sequel to the contributions towards a flora of Brazil by G. Gardner. London Journ. Bot. 2: 629-643, 1843 
\& Curtis, IV. A.

Exotic fungi from the Schweinitzian herbarium, principally from Surinam. Journ. Acad. Nat. Sci. Phila II. 2: 277-294, 1853.

Río Negro fungi. His decades of fungi LI, LXII. Hook Journ. Bot. \& Kew Garden Mise. 8:129-144, 169-177, 193-200, 233241, 272-280, 1856.

On some new fungi from México. Journ. Linn. Soc. Bot. 9: $423-425,1866$.

On a collection of fungi from Cuba. Part II including those belonging to the families Gasteromycetes, Coniomycetes, Hyphomycetes. Plycomycetes and Ascomycetes. Journ. Linn. Soc. Bot. 10:391, 1869.

\section{\& Cooke, NI. C.}

The fungi of Brazil including those collected by J. M. Trail, in 1874. Linn. Soc. Journ. Bot. 15: 363-397, 1876.

Fungi brasiliensis in provincia Río de Janeiro a clar Dr. A. Glancion lecti: In Warming, W. Chmbolae and flora Brasiliae Part XXV Vidensk. Madd. Naturh. For Kjobenh 31/32: 31-34, 1879, 1890.

Betancourt, P. E.

El Mosaico en Cuba. (The mosaic in Cuba.) Rev. Agr. Com. \& Trab. Cuba. 7:23-25, 1925.

Bertoni, M. S.

Una nueva enfermedad del cafeto. (New coffee disease) Rev. Agr. Cien. Apl. Paraguay 1(4-5) : 211-223, 1898.

A summarized account of the coffee-plant diseases. The author describes them briefly including a new one which attacks the coffee roots, which is caused by the fungus Rhizoctonia subepigea n. sp.

Contribución al estudio de la gomosis del naranjo. Agronomía (Puerto Bertoni) Paraguay, 5: 77-89, 1911.

La gomosis de los citrus y un nuevo medio preventivo y eurativo. (Citrus gumosis and means to prevent and cure it.) Ann. Cient. Paraguayos. Ser. 2: 408-421, 1919.

\section{Besadola, Giacomo}

Hymenomycetes Fuegiani a cell viris P. Dusen et O. Nordenskgöld lecti ofver K. Svenska Vetensk-Acad. Förhandl 57:311330, 1900. 
Bianchi, Angel T.

Enfermedad de la papa. (Potato diseases.) Sucor (Argentina) $1(6): 8-9,1920$.

A discussion of dry rot (Fusarizm solani) and wet rot (Phytophthora infestans.)

Enfermedades de la papa (Potato diseases). Defensa Agric. (Uruguay) 2:31-32, 1921.

A brief diseussion of Phytophthora infestans, Fusarium solani and Bacillus amylobactor.

\section{Bird, Maurice}

Soil hygiene in its relation to disease of cane. Journ. Bd. of Agric. Brit. Guiana. 18: 256-261, 1925.

The toxic action of magnesia on sugar cane. Agric. Journ. of Brit. Guiana. 3(3) : 176-179, 1930.

A brief of discussion.

\section{Bitancourt, A[gegislan] A.}

Doeneas cryptogamicas das plantas cultivadas. (Cryptogamic diseases of cultivated plants.) Agronomía, Brazil, 1:239-253, 1930.

As manchas das Laranjas. Descricao das prineipais manchas, podridoes e outras alteracoes das Laranjas, e dos meios para combate-las. (Orange spots. A description of the chief spots, rots, and other disorclers of oranges and measures for their control.) Inst. Biol. Defensa Agric. A Animal, Sao Paulo, Folh. 53, 135 p., 1934.

This is a very useful publications about the ehief orange troubles occurring in Brazil. It contain practical control measures.

\section{Goncalves, R. D., \& Carneiro, J. G.}

Relacao das doencas e fungos parasitas observados na ceceao de phytopathologia durante as annos 1933 e 1934. (Report on the diseases and parasitic fungi observed in the section of phytopathology during the year 1933 and 1934.) Arch. Inst. Biol. Def. Agric. Anim., S. Paulo. 4:206-211, 1935.

The report contains records of Leptosphaeria musarum on bamana, (hatetothyrina musarum on Giant fig fruits and a storage rot due to Stachylidium theobromae. Also a fruit rot of avocado due to Acrostalagmus cinnabarinus. Also a species of Pestalozaia on the branches of avoeado. Beets were arfected by curly top.

As doencas de virus dos Citrus (Virus diseases of Citrus). Biologico, Sao Paulo (Brazil) 1(8):255-262, 1935.

Although not conclusively demonstrated the author states that comparative studies based on the relevant literature and his own observa- 
tions have shown considerable analogies by the syptons caused on citrus trees by psorosis, leprosis, ring blotch and zonate chlorosis and would tend to confirm the view that these diseases are due to virus agencies. He compares the symptoms in different species in Brazil and in United States.

\section{\& Jenkins, Anna E.}

Aleolate spot of Citrus caused by Leptosphaeria bondari. Phytopathology 25(9): 884-886, 1935.

English and Latin diagnoses are given of Leptosphatia bondari n. sp. the agent of aerolate spot a disease of Citrus occurring in Brazil, Dutel Guiana and Venezuela.

A Hemileia e o Brasil (Hemileia and Brazil.) Rev. Inst. Cafe S. Paulo (Brasil) 10(105) : 2106-2109, 1935.

Brief popular notes giving the history and distribution of the fungus Hemileia vastarix, the causative agent of coffee leaf rust. The author attributes the great Brazilian coffee production to the absence of this destructive disense.

Una protozoario parasita do Cafeéiro. (A protozoon parasitic on coffee.) Rev. Inst. Café. 10(107):2486-2490, 1935.

The author reports a coehineal insect (Cerococcus parahybensis) and and the protozoon Rhizoecus cofjeat associated with phloem neerosis of: coffee in the plantations of Parahyba and Pernambuco, Brazil. He discusses Stahel's (from Surinam) observations on the subject.

\section{\& Jenkins, Anna E.}

Elsinoe Fawcetti, the perfect stage of the Citrus scab fungus. Phytopaihology 26(4) : 393-395, 1936.

English and Latin diagnosis are furnished of Elsinoe Fawetti n. sp. the eausal organism of scab lesions on Citrus nobilis rind in Brazil.

Perfect stage of the sweet orange fruit scab fungus. Mycologia 28(5) : 489-492, 1936.

The authors state that the perfect stage of the sweet orange fruit seab fungus [Sphaeceloma Fawcettii viscosa) was foucd in 1936 on Bahia Naval orange (Citrus sinensis) from San Pal lo, Brazil. A description of the fungus follows. The conclusions are that the morphological differences indicated are believed to warrant the separation of the variety viscosa from Elsinoe Fawcetti and it; erection into distinet species for which $E$. australis $\mathrm{n}$. sp. is suggested. The conidial stage is correspondingly renamed $S$. australis Bitancourt \& . Tenlins.

Stomiopeltis citri n. sp. agente da "fuligem" dos Citrus no Estado de Sao Paulo. (Stomiopeltis citri n. s) the causal agent of "sooty blotch" of Citrus in the State of Sao Paulo.) 
Arq. Inst. Biol. de Defensa Agric. \& Animal, (Sao Paulo) 5, 12 p., 1934.

The author gives a detailed morphological account of a fungus, considered as a new species. It causes sooty blotch on citrus. The species affected are sweet and sour oranges, lemons and citrus trifoliata.

\section{Blitin, Walter Leroy}

Comparative morphology of Dothideaceous and kindred stromata. Mycologia, 19(1): 1-20, 1927.

\section{Blinchard, E[verard] $\mathrm{s}$.}

Principales insectos y enfermedades que perjudican el cultivo de la yerba mate. (Chief insects and diseases detrimental to the cultivation of "yerba mate.") Min. Agrie. Nac. (Buenos Aires) Sec. Prop. e Inform. Circ. 735, 42 p., 1928.

This paper gives a record of several diseases.

\section{\& Carrera, César}

Causas que originan pérdidas en los cultivos de trigos en el sur de la Prov. de Buenos Aires, Este y Norte de la Pampa. (Causes that originate losses in wheat culture in the South of Buenos Aires, Province and Tast \& North of the Pampa.) Argentina, Bol. Min. Agric. 32(1) : 3-10, 1933.

Most of this report is devoted to the losses eaused by different forms of wheat foot-rot.

Principales insectos y enfermedades que perjudican los eultivos cítricos en la República Argentina. (Principal insects and diseases which damage the citrus crops in the Argentine Republic.) Min. Agric. Nac. (Buenos Aires) Sec. Prop. \& Inform. Cire. 815, 114 p., 1930.

Notes on symptoms, etiology and control of a great number of diseases of citrus in Argentine. Control methods and fungicide formulas are given.

Bodkin, G. E.

Black blight. Journ. Bd. Agric. Brit. Guiana. 5: 83, 84, 1912.

A black fungus which the author call Aschersonia aleyroidis.

\section{Bondar, Gregorio}

Heterodera radicicola. Bol. Agr. (Sao Paulo) Brazil, 16(4): 329-330, 1915.

Account of the author's observations in regard to the nematode, IIeterodera radicicola. He believes that this nematode does not attack coffee roots under normal conditions. 
O cacao. II, Molestias e inimigos do cacaoeiro. (The cacao. II, Diseases and pest of the cacao tree. Sec. da Agric. Indus. Comm., Vicao e Obras Públicas, Bahia (Brazil), 126 p., 1925.

Discusses Phytophthora faberi, Lasiodiplodia (Botryodiplodia) theobromae, Corticium lilaco-fuscum (C. salmonicolor) and Marasmius perniciosus.

Insectos damninhos e moestias das laranjeiras no Brasil. (Injurious insects and diseases of the orange in Brazil.) Bol. Lab. Path. Veg., Bahia. 7:79, 1929.

Boergesen, F., \& Paulsen, 0 .

Om Vegetation paa de dansk-vestindiske Oer. Bot. Tidssk 22: 111-113, 1898.

Contains numerous records and descriptions of fungi from St. Thomas.

\section{\& Raunkiaer, C.}

Mosses and lichens collected in the former Danish West Indies. Dansk. Bot. Arkiv. 2: 1-18, 1918.

Borg, J.

Orange culture and diseases. Bull. Bot. Dept. Jamaica. N. S. $7: 129-142,1900$.

Bos, Ritzeman

Over Krulloten en Keksen-besems in the eacaoboomen in Suriname. Tijds-chrift over Planzeiekten 6:65, 1900. (Zeitserift für Pflanzenkrankheiten $11: 26-30,1901$.

The fungus causing this disease (witeh-broom) was described by Ritzeman Bos as Exoascus theobromae.

Bouquet de la Grye.

La régénération des plantations de caféiers dans les Antilles. Bulletin des Séames de la Sociéte National d'Agriculture de France, Paris, 59: 683-687, 1899.

Bourne, B. A.

Fungoid attacks reported or observed. Dept. Agriculture (Barbados) Rpt. 1920-21: 10-11, 1921.

A report on Entomology and Mycology in the Report of the Dept. of Agric. for the Barbados, 1921-22: 9-16, 1922.

Rhizoctonia solani and $R$. pallida attack sugar cane. Also reports Colletotrichum falcatum, Cephalosporium sacchari, Leptosphaeria sacchari, Thielaviopsis paradoxa, Cercospora vaginae, Helminthosporium sacchari and Rhizoctonia grisea (Sclerotium griseum). The author also reports Rhizoctonia ferrugena on Andropogon sorghum saccharatus. 
Report of the Assistant Director of Agriculture on the entomological and mycological work carried out during the period under review. Dept. Agric. Barbados, Rept. 1922-23: 7-9, 1923.

Reports Phomopsis vexans on eggplant, Glomerella psidii on Psidium Guajava, Ustilago spp. on Andropogon intermedius var. acidulus and mosaic on sugar cane.

Morphological similarity between the Pythin associated with diseased sugar-cane roots in Hawaii and Puerto Rico. Journ. Dept. Agric. Puerto Rico, 8: 61-70, 1924.

A comparative study.

\section{Bovell, J[ohn] R[edman]}

Field treatment of the diseases of sugar cane in the West Indies. West Indian Bull. 1(1) : 33-42, 1899.

The use of entomogenous fungi on seale insects in Barbados. West Indian Bull. 12(4) : 399-402, 1912.

This paper gives brief discussions of several fungi.

Sugar-cane mosaic. Barbados Dept. Agrid. Ann. Rpt, 1921-22: $19,1922$.

Plant inspection and fumigation. Dept. Agric. Barbados Rept. 1917-18: 31-32, 1930.

Refers to Colletotrichum falcatum, Cercospora vaginae and Marasmius sacchari. Also to the use of Cephalosporium lecanii for the control of Coccus viridis.

Brandes, $\mathbf{E}[\mathrm{lmer}] \mathrm{W}$ [alker]

Report of the plant pathologist. Porto Rico Agr. Expt. Sta. Ann. Rpt. 1915: 34-35, 1916.

Brief notes on the work of the Division during the year. He makes emphasis on the practicability of controlling coffee diseases.

Report of the plant pathologist. Porto Rico Agr. Expt. Sta. Rpt. 1916: 28-31, 1918.

Banana wilt (Panama disease) Puerto Rico Agric. Expt. Stat. Rpt. 1916: 29-31, 4-5, 1918.

Distribution of Fusarium cubense, E. F. S., the cause of banana wilt. Michigan Acad. Sei. Ann. Rpt. 20:271-275, 1918.

A discussion. 
Banana wilt. Phytopathology 9:399-389, 1919.

Kavangerie sugar cane in Puerto Rico. Facts About Sugar 21 (18) : 422-424, 1926.

Bresadola, J., Henning, P., \& Magnus, P.

Die von Herrn P. Sintenis auf der insel Porto Rico 1884-1889 gesammeltenpilze. Reprinted from Engler Bot. Jahrb. 17: 489-501, Leipzig. 1893.

Fungi Brasilienses, lecti a Cl. Dr. Alfredo Möller. Hedwigia $35: 276-302,1896$.

Briant, A. Is. \& Martyn, E[ldred] B[ridgeman]

Diseases of cover crops. Trop. gric. (Trinidad) 6(9) : 258-260, 1929.

The authors discusses three diseases of the sun hemp (Crotalaria juncea) as follows: wilt (Fusarium udum Butler), anthracnose (Cotletotrichum curvatum n. sp.) and a leaf spot (Cercospora sp.). On the sword bean (Canavalia ensiformis) a disease eaused by solerotium rolfsii. On cow pen (Figna catjag) a leaf spot (Cercospora cruenta) a mildew (Oidium) and a mosaic. On the pigeon pas (Cujatus indicus) a rust (Uromyces doticholi) and a stem canker. On the Belgian bean (Stizolobium atorninum) a lenf spot (Cercospora sp.) and a disease caused by Corticium ragum.

Tomato diseases in Trinidad. Journ. Imp. Coll. Trop. Agric. $9: 63-70,101-105,1932$.

A discussion of wilt (Bacterium solanacearum, E. F. S., Fusarium lycopersici Sacc., Sclerotium rolfsii Sacc.), leaf mould (Cladosporium fulvum Cke.), blight (Septoria lycopersici Speg.) fruit rot Phoma destructiva (Plow.) C. O. J. mosaic (virus), root Knot (Heterodera radicicola), late blight (Phytopthora sp.), bacterial blight (Bacillus aroideae Towns.), fruit rot (Phomopsis spp.) Also diseases caused by Gloeosporium sp. and Fusarium sp. Also blossom end rot and blossom drop.

Briton-Jones, H. R.

Mycological notes, I Trop. Agrie. (Trinidad) 4(5): 88, 1927.

Rhizoctonia bataticola and $R$. crocorum attacks Gossypium herbaceum and G. arboreaum. $R$. bataticola also attacks easava.

Rhizoctonia bataticola (Taub.) Butt. Trop. Agric. (Trinidad) $4(8): 147-148,1927$.

This fungus causes a die back. The author established the identity of this fungus and Macrophoma corchori.

Mycological and bacteriological problems (in sugar-cane production.) Trop. Agric. Suppl. (Trinidad) 4(9):51, 1927. 
Hycological notes. Macrophomina phaseoli (Maubl.) Ashby. Trop. Agric. (Trinidad) 4(10): 194-195, 1927.

Refers to the Gadd \& Small controversity on Rhizoctonia bataticola (Macrophoma phaseoli).

Report on a visit to St. Lucia, March, 1927.

A note on green muscardine (Metarrhizium anisopliae Sorokin.) Minutes and Proc. Froghopper Invest. Ctte. (Trinidad \& Tobago) 9:293-305, 1927.

A brief review of the previous work for the control of Tomaspis saccharina in Trinidad by the use of Metarihizium anisipliae.

Root diseases in the British West Indies and note on Diaporthe perniciosus Marshall or a closely related species. Tropical Agric. (Trinidad) 5: 496, 1928.

Witch broom disease. Trop. Agric. (Trinidad) 6(1):20-22, 1929.

A review of Stell's witch broom disease of eacao and its eontrol.

Wilt disease of coconut palms in Trinidad. (Part I) Suppl. to Trop. Agrie., (Trinidad) 5:1-2, 1928.

The coconut is attacked by two diseases; the bud rot (Phytophthora palmivorum) and ring rot (Aphelenchus cocophilus). The author gives a historical discussion of these two diseases. He then describes a false wilt, bronze leaf wilt caused by soil and a yellow leaf or tapering stem disease. Also control measures.

Root diseases in the British West Indies and a note on Diaporthe perniciosus Marchal or a closely related species. Trop. Agric. (Trinidad) 5(4):79-82, 1928. (5) : 107-110.

The author gives a general discussion of Macrophomina phaseoli in the West Indies, a list of synonyms and also a discussion on Sphaerostilbe repens, Rosellinia pepo, $R$. bunodes, Pythiacystis citrophora, Fomes lignosus, Diaporthe perniciosa, die back and withe tip of limes, ete.

Gummosis in Barbados. Trop. Agric. (Trinidad) 6(12):340, 1929.

Probably the first record in Barbados.

Wilt disease of coconut palms in Trinidad. Part II. Trop. Agric. (Trinidad) Suppl. 6:1-12, 1929. 
Control of the American leaf disease (Omphatia flavida) on Arabian coffee in Trinidad Mem. Imp. Col. Trop. Agric. Trinidad, Mycol. 2, 8 p., 1930.

Account on the distribution of this disease and the conditions that effect its spread.

\section{\& IIarshall, R. C.}

Observations on sypre (Cordia alliodora L.) in Trinidad with special reference to canker disease. (Puccinia cordiae (P. Henn.) Arth.) Part I. Mycologia. Mem. Imp. Coll. Trop. Agric. Trinidad No. 3:3-7, 1930.

The author discusses the fungus (Puccinia cordiae (P. Henn.) Arthur., giving its description; hyperparasite (Tuberculina vinosa Sace.) and control measures.

\section{\& Cheeseman, E. ㅍ. ‥}

Witch broom control. New aspect of witch broom control in Trinidad (Marasmius perniciosus Stahel) Trop. Agric. (Trinidad) 8(4): 79-89, 1931.

A very complete report of work by the author.

Trinidad plant diseases; notes on some disease of main crops in Trinidad. Trop. Agri. (Trinidad) 8(1) : 300-302, 1931.

Stripe disease of corn (Zea mays, L.) in Trinidad. Trop. Agric. (Trinidad) 10(5): 119-122, 1933.

The author observed since 1929 a stripe disease of corn which occurred in Trinidad and closely resembling that described by Stahl in Cuba. That disease was associated with the leafhopper Peregrinus maidis as vector, both in Cuba and Tanganyka. The author deseribed the disease and his observations on inoculation studies. A similar disease resembling the one under discussion was observed also on sorghum.

Thread blights in Trinidad. Journ. Imp. Coll. Trop. Agric. $11(2): 55-57,1934$.

A very through study of these blights. The author attribute the disease to Corticium Kolerogo, C. Stevensii and to an undetermined species.

\section{Baker, R. E. D.}

Notes on some other fungous diseases in Trinidad. 1933. Journ. Imp. Coll. Trop. Agric. 11(2):67-68, 1934.

The author gives a discussion of Septobasidium sp. on grape fruit, Rhizoctonia solani on briar rose, Corticium salmonicolor on grape fruit and Sclerotium rolfsii on several plants. 
The control of scab disease (Sporotrichum citri Butler) in the British West Indies. Trop. Agrie. (Trinidad) 10(2):40-42, 1933 .

The results of spraying experiments. This treatment also controls the leaf spot (Colletotrichum zingiberis) of ginger.

Preliminary trials with a combined insecticide and fungicide.Trop. Agric. 10(3): 80-\$4, 1933.

A brief aceount of experimental work for the control of Marasmins perniciosus on the cacao. Also for the control of Phytophthora palmivora on eacio.

The diseases and curing of eacao. London, MeMillan Co., 161 p., 1934.

A manual. It contain; much information on eacao diseases in Aneris":

Problems comected with root disease of sugar eane in Antigua. Trop. Agrice (Triniclad) 13(1):5-8, 1936.

Reters to Maresmius sachari, Sclerotium rolfsib, and Bacterium rascinerum.

\section{Britton, M[athaniel] tord]}

The vegetation on Mona Island, Am. Ho. Bot. Garden 2:3358,1915 .

It contains at list of Basiomyectes and Uredinales.

Brooks, Archivald Joseph

lnvestigntions in connection with cacaonroot disease. St. Lueía Dept. Agrie. Rpt. 1913-14: 8, 1914.

Report on the Agricultural Department, St. Lucia, Imp. Dept. of Agric. West Indies Report. Agrie. Dept. St. Lucía, 1918$19: 32,1920$.

Brown, D. $I$.

The cultivation of yams (Fungous and insect pests.) Trop. Agrie. (Trinidad) 8:231-236, 1931 .

\section{Bruner, s[tephen] o[ole]}

La "Phomopsis" de la berenjena (Egoplant Phomopsis.) Rev. Agrie. Com. \& Trab. Cuba. 1:368-369, 1918.

La purtrieión del tomate y modo de evitarla (Decay of tomatoes and methods of prevention.) Rev. Agric. Com. Trab. (Cuba) $1: 300-301,1918$.

A report on decays of tomatoes exported to the United States in. eluting a list of several fungi. 
Enfermedades de la vid en Cuba. (Diseases of the grape in Cuba) Rev. Agric. Com. Trab. (Cuba) 1:406-409, 1918.

A report on several diseases.

La "Phomopsis" de la berenjena (Phomopsis disease of eggplant.) Rev. Agric. Com. Trab. (Cuba):1:468-469, 1918. (Rev. Agric. México) : 1 :31-32, 1919.)

Recommendations for control.

Caícla de las nueces e inclinación de las hojas del cocotero en Cuba. (Nut fall and leaf drop of coconut in Cuba.) Rev. Agric. Com. Trab. (Cuba) 2:96, 1919.

The author says that Fox makes and erroneous report of this disease in the Cuba Reviews (Dec., 1918).

Un honguillo parásito del tingitido de la higuereta. (A fungous parasite of an insect on the castor bean) Rev. Agric. Com. Trab. (Cuba) 2:218-219, 1919.

The fungus is Sporotrichum globuliferum and it attacks Corythuca gossypii.

La enfermedad del mosaico o de rayas amarillas de la caña de azúcar en Cuba. (The mosaic or yellow stripe disease of sugar cane in Cuba.) Rev. Agric. Com. \& Trab. Cuba. 2 (9) : $437-441,1919$.

Record of the occurrence of the disease and review.

Notas sobre la enfermedad del mosaico de la caña de azúcar. (Notes of sugar-cane mosaic disease.) Rev. Agric. Com. \& Trab. (Cuba) 2: 532-533, 1919.

The disease is infectious in character. Healthy plantings became infected from nearby diseased plantings.

Informe sobre enfermedades del cafeto. (Report on diseases of the coffee trees.) Cuba, Est. Expt. Agr. Santiago de las Vegas. Inf. Anual 1918-20:628-632, 1920. (Rev. Agr. Com. \& Trab. Cuba. 2(11) : 533-535, 1919.

Notes on the following fungus diseases of coffee Pellicularia Koleroga, Stilbella flavida and Cercospora coffeicola. He gives recomendations to fight these diseases.

Lista preliminar de las enfermedades de las plantas de importaneia económica para Cuba. (Contribución al estudio de la fitopatología.) (Preliminary list of the diseases of the plants 
of economic importance for Cuba. A contribution to the study of plant pathology.) Cuba, Est. Expt. Agron. Inf. Ann. 1918-20:723-763, 1920.

La pudrición negra del cacao. (Black rot of cacao.) Informe Ann. Estación Expt. Agron. (Cuba) 1918-20:627-628, 1920. (Rev. Agric. Com. \& Trabajo (Cuba) 2:630-636, 1919.)

The black rot disease caused by Phytophthora faberi has been reported in Cuba for first time.

The disease is described and control recommended.

Algunas observaciones sobre la enfermedad del "mosaico" o "rayas amarillas" de la caña de azúcar. (Observations on the "mosaic" or "yellow stripe" disease of sugar cane.) Rev. Agric. Com. \& Trab. Cuba 4(6):616-620, 1921.

A review of work on resistant varieties in Puerto Rico, Hawaii and Jamaica. Gives a list of susceptible and resistant varieties.

Exploración biológica y fitopatológica en la Provincia de Pinar del Río. (Biological and Phytopathological exploration in the Province of Pinar del Río.) Rev. Agric. Com. \& Trab. Cuba. 5(4): 27, 1922.

Records the occurrenee of mosaic disease on sugar eane in Taco Taco in the Province of Pinar del Río, Cuba.

La muerte de los cocoteros. (The death of coconut trees.) Rev. Agrie. Com. Trabajo (Cuba) 5(1):9-10, 1922.

Popular.

Sobre la transmisión de la enfermedad del "Mosaico" o "Rayas Amarillas" en la caña de azúcar. (On the transmission of Mosaic or "Yellow Stripe Disease" of sugar cane.) Rev. Agr. Com. \& Trab., Cuba. (5(1):11-22, 1922.

Bibliogratía. La enfermedad de las "Rayas Amarillas" en la caña. (Bibliography. The sugar cane "Yellow Stripe" disease.) Rev. Agric. Com. \& Trab. Cuba 5(2): 32-33, 1922.

A review of a paper by Simonetto.

El mosaico y otras enfermedades y plagas de la caña en Cuba. (Mosaic and other cane diseases and pests in Cuba.) Mundo Azucarero 2(1):20-27, 1923. (Louisiana Planter. 70(22): 452-455, 1923. Rev. Appl. Myco. 2:523-524, 1923.)

The mosaic does not appear to spread as rapidly in Cuba as in Puerto Rico. Recommends the use of resistant and immune varieties. 
La enfermedad del mosaico de la Caña de Azúcar. (Mosaic disease of sugar cane.) Cuba, Est. Expt. Agron. Circ. 60, 16 p., 1923. (Facts About Sugar 18(14): 329, 1924.

A discussion of conditions in Cuba.

La enfermedad del mosaico de la caña de azúcar. (Mosaic disease of sugar cane.) Argentina Ind. Azucarera 29(366):228237, 1924.

La situación respecto al "Mosaico" de la caña de azúcar en Jamaica. (The situation in regard to sugar cane in Jamaica.) Rev. Agric. Com. \& Trab. Cuba. 8(1):74-76, 1926. (Agricultura, Cuba 1(1):160-162. 1925.)

El problema de la libre importación de papas, (The problem of free importation of potatoes.) Rev. de Agric. Com. Trab. (Cuba) 8(2): 36-39, 1926.

Refers to danger of introducing diseases.

\& Arango, Oscar

La enfermedad "Verruga" de las habas de Lima. (Scab of Lima beans) Est. Expt. Agron. (Santiago de las Vegas, Cuba) Cire. 74, 58 p., 1931.

The disease is caused by a species of Elsinoe closely related to Elsinoe canavaliae.

Informe del departamenio de entomología y fitopatología. Ejercicio de 1929 a 1930. Repub. Cuba. Sec. Agric. Com. Trab. Estación Expt. Agron. 1931: 5-74, 1931.

A general report.

\& Jenkins, Anna E.

Identity and host relations of the Elsinoe of lima bean. Journ. Agrie. Res. 47(10) : 783-789, 1933.

The results of studies made in Cuba.

\section{Brunini, Vicente}

Resultados obtenidos en algunas experiencias sobre carbón volatil y caries del trigo. (Some results obtained in some experiences on loose smut and caries of wheat.) Nuestra Chacra (Argentina) $4(21): 9-11,1929$.

Experimental data of plant resistance to wheat loose smut and caries.

Bubák, F., \& Sydow, H[ans]

Einige neue Pilze. (Some new fungi.) Ann. Mycol. $31: 7-12$, 1915. 


\section{Burt, $\mathbf{E}[$ dward] $\mathbf{A}[$ ngus]}

Some hymenomycetous Fungi from South America. Bull. Torr. Bot. Club. 29: 571-572, 1902.

Odontia sacchari and $O$. saccharicola, new species on sugar cane. Ann. Missouri Bot. Gard. 4(3): 233-236, 1917.

Descriptions of these two new species.

Corticiums causing Pelicularia disease of the coffee plant, Hypochnose of Pomaceous fruits and Rhyzoctonia diseases. Ann. Missouri Bot. Gard. 5 : 119-132, 1918.

\section{Busck, August}

Report on the investigations of diseased coconut palms in Cuba. U.S.D.A. Br. Ent. n. s. Bull. 38: 20-23, 1902.

\section{Byars, L[uther] $\mathbb{P}$ [arris]}

Notes on the citrus-root nematodes, Tylenchus semi-penetrans. Phytopathology 11(2) : 90-94, 1921.

\section{Cabrera, César}

Informe preliminar sobre una enfermedad nueva comprobada en los Citrus de Bella Vista (Corrientes) (Preliminary report on a new disease of citrus at Bella Vista (Corrientes). Argentina, Bol. Mins. Agric. 34(3-4) : 375-380, 1933.

Report on an outbreak of anthracnosis of the citrus (Colletotrichum gloeosporioides Penz.)

Cafvalle 'D' Almeida, J. 'E.

El "mildiú" del cacao en las islas de St. Thomas y Príncipe. Bull. Ofic. Soc. Agric. Cuba. 17(3): 213-216, 1914.

Calderini, G.

Estudio sobre las enfermedades de la papa. (Studies on potato. diseases.) Rev. Nac. Agr. Soc. Agr. (Colombia) 26:670676, 1935.

Calvino, IM[ario]

Informe de los años 1918, 1919 y 1920 de la Estación Experimental Agronómica Santiago de las Vegas, Cuba. (Anual Report for the years 1918, 1919, 1920 of the Agricultural Experiment Station, Cuba) p. 547-550, 1920.

Doce Puntos Relacionados con el mosaico de la caña de azúcar $\mathrm{y}$ el modo de combatirlo. (Twelve Points related to sugarcane mosaic disease and methods to control it.) Rev. Agric. Com. \& Trab. Cuba 5(12): 6-7, 1924. 
Nuevas orientaciones en la selección de caña para semilla. (New orientations in sugar-cane seed selection.) Rev. Agric. Com. \& Trab. Cuba, 5(12): 8-10, 1924.

Camacho, C.

La agricultura de Tacna (Agriculture in the province of Tacna) (Chile) 27 p., 1923.

Reports gummosis on Citrus.

Os adubos verdos e as safras de cobertura na cultura eafeeira. I, Importancia e afeitos. D. N. C. Rev. Dep. Nac. Café, (Río de Janeiro) 5: 807-811, 1935.

(Co. 290 cane at Campos, Brazil. Observations on cane culture in Brazil.) Brasil Assuc. 5(3): 12 $\bar{\imath}-138,335-341,1935$. (Facts About Sugar (Abstract) 30(8): 304-305, 1935.)

Record of observations on sugar-cane variety resistance to mosaic

Sugar cane diseases in Brazil. Brasil Assuc. 7(4): 209-213, 1936. (Facts About Sugar (Abstract) $31(12): 471,1936$.)

According to the author the major sugar-cane diseases in Brazil are gummosis (Bacterium vascularum), mosaie, Sereh and red stripe (Bact. rubrilineans). Account is given as to varietal resistance and behavior.

Sugar-cane diseases in Brazil II, Brasil Assue 7(5) : 289-290, 1936. (Facts About Sugar (Abstract) 31(11) : 427, 1936.)

Continuation of preceeding paper. The minor sugar-eane diseases are given.

\section{Caminha Filho, Adriao}

Relatorio de mez de setembro de 1925, do auxiliar de inspector agrícola de defesa do cafe-na zona de Matta. (Report for the month of September 1925, of the assistant agrieultural inspector for the defence of coffee in the zone of Matta. Bol. Minist. Agr. Ind. \& Comm. Río de Janeiro 15: 125-127, 1926.

Campbell, teo

Some species of Plasmopara on composites from Guatemala. Mycologia $24:$ 330-333, 1932.

Campos, F. 0 .

El cáncer del cacao (Cacao canker). Rev. Agric. 16:53-55, 1920.

\section{Campos Novaes, José De}

A cura de gomose dar Laranjeiras Phythiacystis citrophora. (The cure of orange gummosis (Pythiacystis citrophora) Bol. Agric. Sao Paulo, Ser. 29a, (11-12) : 6S1-6S9, $192 \mathrm{~S}$. 
Quadro synoptico e practico da phytopathologia brasileira. (Synoptic and practical (able of Brazilian phytopathology.) Characas e Quintaes 35:425-432, 1927; 40:282-288, 1929.

\section{Camuñas 'Manuel}

Report of the Commissioner of Agriculture and Labor. 19th. Ann. Rpt. Govt. Pto. Rico to Secretary of War, Washington, D. C. Appendix IX, pp. 685-707, 1919. (Rev. Appl. Ent. ser A, 9:332, 1919.)

A record of the occurrence of mosaic of sugar cane in Puerto Rico.

Canu, $\mathbb{G}$.

Después del oidium. (After the Oidium.) Bol. Soc. Nac. Agric. Chile. 63: 319-321, 1931.

Carvalho, J. N. de

$\mathrm{O}$ cafeiro e suas pragas na Parahyba. (The coffee tree and its pests in Parahyba.) Agron. Ann. Soc. Brasil. Agron. 1:99118, 1930.

The two principal diseases of coffee in Parahyba, Brazil, are caused by the fungi Cercospora coffeicola and Rosellinia necatrix. The author describes both diseases and the organisms.

\section{Cardín, Patricio}

Informe del Depto. de Path. Vegetal y Entomología. Cuba Ext. Expt. Agron. Santiago de las Vegas. Inf. Ann. 1909-14: 110-111, 1915.

\section{Carleton, IM[ark] A[lfred]}

Note on the Fusarium wilt disease of bananas. Science, N. S. $56(1458): 663-664,1922$.

Refers to a paper by E. Gaumamm "Over een bactericelee vatbundelziekte der bananen in Nederlandsch, Indie, Meded. V. H. Instituut V. Plantenziekten, No. 48, Dept. N. Landbouw, Nijverheid en Handel, pp. 135, 1921, in which an effort is made to discredit the work of Brandes (Phyto. 8(9):339-389, 1919.

Carleton gives the results of studies confirming the work of Brandes.

\section{Carrera, César}

Informe de las observaciones y experimentaciones efectuadas sobre una nueva enfermedad aparecida en los Citrus de Bella Vista (Corrientes). (Report on the observations and experiments carried out on a new Citrus disease that has developed at Bella Vista (Corriente) Bol. Minist. Agric. Buenos Aires, $37(1-4): 15-36,1935$.

After inoculation studies with three species of Fusarium (F. oxysporum var. aurantiacum, $F$. solani var. Martini and $F$. solani) with negative results, the author concludes that the primary factors are nutritional and physiological. Control measures are given. 
Fusurium de la República Argentina. Estudio y clasificación de algunas especies. (Fusarium in the Argentine Republic. A study and classification of certain species.) Physis, Buenos Aires, 12(41) : 43-47, 1936.

An annotated list of several species of Fusarium occurring in Argentina.

\section{Catoni, Luis $\mathrm{A}$ [ntonio]}

Una enfermedad del cocotero que no queremos en Puerto Rico. (A coconut palm disease which we do not want in Puerto Rico.) Puerto Rico, Ins. Expt. Sta. Circ. 43, 7 p., 1921.

\section{Cengia-Sambo, IVI.}

Licheni della terra del Fuoco recolth da G. B. De Gasperi nel 1913. (Lichens from Tierra del Fuego collected by G. B. De Gasperi in 1913.) Bull. Soc. Bot. Stal. 1926(4/5) : 81-92, 1926.

\section{Chardon, C[arlos] $\mathrm{E}$ [ugenio]}

A list of Pyrenomycetes of Puerto Rico collected by $\mathrm{H} . \mathrm{H}$. Whetzel and E. W. Olive. Mycologia 12:316-321, 1920.

A contribution to our knowledge of the Pyrenomycetes of Puerto Rico. Mycología 13(6) : 279-300, 1921.

Un nuevo "smut" de Puerto Rico. (A new smut from Puerto Rico.) Rev. Agric. Puerto Rico. 6(4): 21-23, 1921.

Resumen de la literatura sobre el origen de las enfermedades del "mosaico" en las plantas. (Review of the literature about the origin of "mosaic" disease of plants.) Rev. Agric. Puerto Rico 9(4): 13-22, 1922.

A review of the literature and list of publications.

\& Veve $\mathbf{R}[$ afael] A.

Sobre la transmisión del matizado de la caña por medio de insectos. (About the transmission of sugar cane mosaic by means of insects.) Memoire Asso'n. Sugar Tech. Puerto Rico 1(1) : 9-12, 1922. (Rev. Agric. Puerto Rico 9(2) : 9-20, 1922. Facts About Sugar 15(4) : 281-284, 1922. Louisiana Planter \& Sugar Manuf. 69(19): 323-324, 1922.)

Gives the results of experiments which proved that Aphis maidis is a carrier.

Informe anual del Patólogo Especial para el Año fiscal 1921-22. (Annual Report of the Special Pathologist for the fiscal year 1921-22.) Ins. Expt. Sta. Puerto Rico, Ann. Rpt. 1921-22: 67-74, 1922. 
La transmisión del mosaico. (Mosaic Transmission.) Sugar $25: 477-478,1924$.

Mosaic investigations at Central Cambalache. (Preliminary Report.) Journ. Dept. Agric. Puerto Rico 8(2):27-39, 1924. (Int. Sugar Journ. 27(324) :649-651, 1925. Rev. Appl. Mycol. 4:505-506, 1924. Rev. Agric. Puerto Rico. 13:205218, 1924. Facts About Sugar 19:569, 1924.)

\section{\& Veve $R$ [afael] A.}

The transmission of sugar-cane mosaic by Aphis maidis under field conditions in Puerto Rico. Phytopathology 13(1):2429, 1923. (Rev. Appl. Mycol. 2: 390-391, 1923. Rev. Appl. Ent. ser. A. 12(2): 40, 1924. Rev. Agric. Com. \& Trab. (Cuba) $7(2): 37-41,1924$.)

This paper gives the results of experiments which demonstrate that the disease is carried by Aphis maidis. Also some grass hosts of the disease.

La relación de ciertas yerbas con el matizado de la caña de azúcar. (Relation of certain weeds with sugar-cane mosaic.) Rev. Agric. Puerto Rico. 12(5) : 305-314, 1924. (Rev. Appl. Ent. ser. A. $12(2): 40,1924$. Rev. Agric. Com. \& Trab. Cuba, $7(2): 37-41,1924$.

A study of the disease with special reference to Aphis maidis and certain grass hosts.

Mosaico o matizado de la caña de azúcar. (Mosaic or Mottling of Sugar Cane.) Rev. Agric. Puerto Rico. 14(3) : 188-197, 1925. (Rev. Appl. Mycol. 4:635, 1925.)

Notes of a conference delivered in Cuba.

Observaciones sobre las enfermedades del café. (Observations on coffee diseases.) Inf. Esc. Sup. Agric. Med. Vet. Medellin. (Colombia) p., 43-52, 1926.

La gomosis, una epidemia grave de la caña en Antioquía. Gobierno Departamental de Antioquía (Colegio de Agricultura y Veterinaria. Colombia. Cire. 1, 22 p., 1926.

The author gives a brief popular review of the history, symptoms, methods of transmission of the disease. Also a discussion of resistant and susceptible varieties. 
314 THE JOURNAL OF AGRICULTURE OF THE UNIVERSITY OF P. R.

\section{\& Toro, Rafael A[ndrés]}

Plant diseases notes from the Central Andes. Phytopathology $17: 147-153,1927$.

Account of the observations made by the authors during a trip to that region.

La Revolución de las variedades de caña en Puerto Rico. (The Varietal Revolution of Sugar Cane in Puerto Rico.) Rev. Agric. Puerto Rico 18(3) : 117-127; 1927. (Rev. Appl. Mycol. 6:581, 1927; Planter \& Sugar Mfg. 78(22) : 429-430; (23): 451-453, 460, 1927. Journ. Dept. Agric. Puerto Rico. 11 $(1-4): 9-14,1927$.

This paper includes a discussion of the relation of mosaic to the varietal revolution of sugar cane in Puerto Rico.

The Agricultural Revolution in Puerto Rico. Facts About Sugar 22: 894-897, 1927.

Observaciones sobre las enfermedades de café en Colombia. (Observations on the coflee diseases in Colombia.) Rev. Agr. Puerto Rico 13(1): 5-9, 29, 1927.

Taken from the report rendered by the author to the Governor of the State of Antioquía (Colombia) on the reorganization of the "Escuela Superior de Agricultura y Medicina Veterinaria', The author gives his observations on coffee diseases in Colombia and gives brief description of those observed.

New or interesting tropical American Dothideales I. Mycologia $19(6)$ : 295-301, 1927.

Contribución al estudio de la flora micológica de Colombia. (Contribution to the study of the mycological flora of Colombia.) Bol. Real Soc. Española Hist. Nat. 28:111-124, 1928.

New or interesting tropical American Dothideales II. Journ. Dept. Agric. Puerto Rico 13(1) : 6-17, 1929.

\section{\& Toro, Rafael A[ndrés]}

Mycological exploration of Colombia. Journ. Dept. Agric. Puerto Rico. 14(4): 195-369, 1930.

Exploraciones micológicas en Venezuela. (Mycological exploration in Venezuela.) Bol. Soc. Venezolana Cienc. Nat. 8:281294, 1932. 
New or interesting tropical American Dothideales III. Journ. Dept. Agric. Puerto Rico 16(2) : 167-192, 1932.

Life Zones in the Andes of Venezuela. Bull. Pan-American Union 67: 620-633, 1933.

Mycological explorations of Venezuela. Men. Univ. Puerto Rico. Phy \& Biol. ser. B. 2, 353 p., 1934.

\section{Charlan, $F$.}

Las viruelas y rollas del tabaco en la República Argentina. (Spots and rusts of tobacco in the Argentine Republic.) Mins. Agric. Cire. 397, 4 p., 1925.

Charles. Vera $\mathrm{I}$.

The occurrence of Lasiodiplodia on cacao and mangoes. Journ. Mycol. $12(84)$ : 145-146, 1906.

Cheesman, 正. I.

Banana breeding at the Imperial College of Tropical Agriculture. A progress report. Empire Marketing Bd. Publ. 47, 35 p., 1931.

A study of Tusarium cubense.

Christ, Bermann

Filiceas brasilienses ... ab ... A. Goeldi \& J. Huber lactae

(Dresden, 1906). p. 190-194. (Hedwigia 45.)

Ciferri, R[afael] \& Conzález Fragoso, R[omualdo]

Parasitic and Saprophytic Fungi of the Dominican Republic. Bol. R. Soe. Esp. Hist. Nat., 25(8) : 356-368, 1925.

\section{\&}

Iconografía de hongos parásitos y saprófitos de la República Dominieana. Series 1-6 (Collected pictures of parasitic and saprophytic fungi of the Dominican Republic, Series 1-6) Public. Estac. Agron. de Hoca. República Dominicana, Ser. B., Bot. 9: 3-5, 1926.

Informe de patología vegetal y entomología agrícola. (Report on plant pathology and Agricultural entomology.) Primer Informe Anual de la Estación Agron. y Col. de Agric. de Haina, Rep. Dominicana. I. de abril 31 de diciembre 1925; p. 27-36, 1928.

Several diseases and causal organisms are listed. 
THE JOURNAL OF AGRICULTURE OF THE UNIVERSITY OF $P$. R.

\section{\& González Fragoso, R[omualdo]}

Hongos parásitos y saprófitos de la República Dominicana (4 Serie). (Parasitic and saprophytic fungi of the Dominican Republic, 4th Series.) Bol. R. Soc. Esp. Hist. Nat. 26(3) : 192-202, 1926.

\section{\&}

Hongos parásitos y saprófitos de la República Dominicana (5 Serie). (Parasitic and saprophytic fungi of the Dominican Republic, (5th series). Bol. R. Soc. Esp. Hist. Nat. 26(4) : 248-258, 1926.

Hongos parásitos y saprófitos de la República Dominicana (7 Serie). (Parasitic and saprophytic fungi of the Dominican Republic. (7th series). Bol. R. Soc. Esp. Hist. Nat. 26(6) : 470-480, 1926.

Hongos parásitos y saprófitos de la República Dominicana, 8 Serie. (Parasitic and saprophytic fungi of the Dominican Republic. 8th series.) Bol. R. Soc. Esp. Hist. Nat. 26(10): 491-499, 1926.

Segundo Inform. Ann. Estac. Nac. Agron. Moca. Rep. Dominicana. (Report on Phytopathology. Principal disease of cultivated plants observed during the year 1926.) 1928:27-44, 1927.

Contains a list of principal plant diseases.

$\&$

Hongos parásitos y saprófitos de la República Dominicana (9 serie). Parasitic and saprophytic fungi of the Dominican Republic, (9th Series). Bol. R. Soc. Esp. Hist. Nat. 27(2) : 68-91, Ibid (10 Serie) ibid (4) : 165-177, 1927.

Studies über kapa. I. Untersuchungen über den muffigen Geruchder kapabolinen. (Studies on cacao, I. Investigations on the musty odor of cacao beans.) Centrabl. für Bakt. Ab. II. $71(1-7): 80-93,1927$.

These studies were made in the Dominican Republic. Mentions several fungi on the cacao bean.

\section{\& González Fragoso, R[omualdo]}

Hongos parásitos y saprófitos de la República Dominicana (11 Serie). (Parasitic and saprophytic fungi of the Dominican Republic. (11th series). Bol. R. Soc. Esp. Hist. Nat. 27(6) : 267-280, 1927.

Matal mycological et phytopathological. Serie II, No. 1-15. (Mycological and phytopathological notes series II, Nos. 1-15.) Rev. Patol. Veg. 17(9-10) : 209-294, 1927. 


\section{\& González Fragoso, R[omualdo]}

Hongos parásitos y saprófitos de la República Dominicana.

Serie). (Parasitic nad saprophytic fungi of the Dominican Republic. 12th Series. Bol. R. Soc. Esp. Hist. Nat. 27(7): 323-334, 1927.

Dominican Republic: a disease of the mulberry new to the community. Internat. Bull. Plant Protect. 2(2): 18, 1928.

A record of Pseudomonas (Bacterium) more on Morus sp.

\section{\& González Fragoso, R[omualdo]}

Hongos parásitos y saprófitos de la República Dominicana (15 Serie). (Parasitic and saprophytic fungi of the Dominican Republic (15th Serie). Bol. R. Soc. Esp. Hist. Nat. 28(4): 221-228, 1928.

Preliminary observations on sugar cane Mycrorrhizae and their relationship to root diseases. Phytopathology 18(3) : 249-261, 1928.

These studies were made in the Dominican Republic. They refer to Pythium and Rhizoctonia.

\section{\& González Fragoso, R[omualdo]}

Hongos parásitos y saprófitos de la República Dominiana. (Parasitic and saprofitic fungi from the Dominican Republic.) Bol. Real Soc. Esp. Hist. Nat. 28: 131-144, 1928.

Quarta contribuzione allo studio degli Ustilaginales. (Fourth contribution to the study of the Ustilaginales.) Ann. Mycol. $26(1 / 2): 1-68,1928$.

Osservazioni sulla specializzazione dell "Albugo ipomoeae-panduratae" (Schw.) Sw. (Observation on the specialization of Albugo ipomoeae-panduratae (Schw.) Sw.) Nuevo Giorn. Bol. Stal. 35(1) : 112-133, 1928.

Microflora Dominicensis. Lista de hongos hasta la fecha indicados en Santo Domingo (Microflora Dominicana. List of fungi reported up to this date in Santo Domingo.) Rep. Dominicana, Est. Agron. de Moca, Ser. B. Botánica. 14:5$260,1929$.

Phytopathological survey of Santo Domingo. Journ. Dept. Agric. Puerto Rico. 14(1) : 5-44, 1929.

A list of 175 diseases on 53 cultivated plants.

Informe general sobre la industria cacaotera de Santo Domingo. (General information on the cacao industry of Santo Domingo. Estac. Agron. de Moca. Ser. B-Bot. 16, 190 p., 1930. Notes on several parasitic fungi. 
Mycoflora dominicensis exsiccata. Ann. Mycol. 29:283-299, 1931.

\section{\& Bruner, s[tephen] C[ole.]}

Cercospora bataticola n. sp. parasite of the sweet potato in America. Phytopathology 21: 93-96, 1931.

Contribution to the classification of Torulopsidaceae. 1.-An american variety of the Torulopis minuta. Mycologia 23:140146, 1931.

Smuts collected in the Dominican Republic, by E. L. Ekman. I. Arkiv. für Botanik Band 23A: 1-29, 1931.

In addition to those of Santo Domingo mentioned also several species from Puerto Rico.

Studies on cacao. Journ. Dept. Agric. Puerto Rico 15(3) : 223286, 1931.

Contains a record of a large number of fungi found on fermenting cacao.

\& Herter, W. G.

Ustilaginales Uruguayenses; Itinera Herteriana IV. (Uruguayan Ustilaginales; Herter's itenerany IV.) Bot. Arch., 34 (344) : 527-540, 1932.

A list of 35 species collected in Uruguay.

Itinera Herteriana. I Report. Spec. Nov. 15:373-382, 1918. II, 394-396, 1918. III, Bot. Contrabl. 2 Abt. 39:248-256, 1922. IV, Ustilaginales Uruguayenses Bot. Arch. 34:527$540,1932$.

Mycoflora Domingensis exsiccata. Ann. Mycol. 31:144-167, 1933.

Measuring the intensity of discoloration of sugar-cane leaves. Proc. Fourth Congr. Intern. Soc. Sugar-Cane Technologists, 1932. (Facts About Sugar (Abstract) $27(6): 260,1932$.

The author describes his procedure and observations with the Mois nephelo-absortimeter while measuring the intensity of light through leaves of "Cristalina" variety of sugar cane which is susceptible to mosaic. The infested leaves showed that the opacity is about 2 per cent greater than that of healthy foliage and practically constant.

Thickness of mottled and healthy sugar cane leaves. . Proc. Fourth Intern. Congr. Soc. Sugar-Cane Technologist, 1932. (Facts About Sugar (Abstract) 27(6):260, 1932.) 
Based on 17,620 micrometic measurements with galvanometric control of the thickness of mottled and healthy leaves of sugar-cane varieties susceptible to mosaic. He observed that the diseased leaves are slightly thicker than the healthy ones.

La distribuzione e la nomenclarura dei carboni della canna de zucchero e delle specie affini. (The distribution and nomenclature of the smuts of sugar cane and allied species.) Boll. Studi ee Informaz. R. Giard di Polermo, 13, 7 pp., 1933.

He believes that Ustilago scitaminea which has been reported from North America, Trinidad, British Guiana and Brazil does not occur in those countries.

Le malattie della Manioca (Manihot esculenta Crantz) in Santo Domingo. I. Notizie Bull' ambiente in eui si effecttuaro gli Studi. II. La malattia delle macchie fogliari circolari (Helminthosporium hispaniolae, Cif. (The disease of Cassava (Manihot esculenta Crantz) in Santo Domingo. I. Notes on the environmental conditions in which the investigations were conducted. II. The circular leaf spot disease (Helminthosporium hispaniolae Cif.) Boll. R. Staz. Pat. Veg., N. S., $13(2): 227-240$ \& 241-308, 1933.

\& Parodi, : E.

Descrizione del fungo che cause la "moniliasi" del cacao. (A description of the fungus causing "moniliasi" of cacao.) Phytopath. Zeitschr., 6(5): 539-542, 1933.

A paper based on material sent from Colombia.

Sulla posizione sistematica dell' Aegeritha duthiei, fungo dell' "ambrosia" deitermitai. (On the systematic position of Aegerith duthiei, the fungus of the "Ambrosia" of termites nests.) Atti. Inst. Bot. Univ. Pavia 4(6) : 229-246, 1935.

The author gives a Latin diagnose of the genus and transfers Aegeritha duthiei to Termintosphaeria dutheiei n, comb. This is the fungus found in the nest of the termite Nasutitermes morio in the Dominican Republic.

\section{Clements, F[ederic] $\mathrm{F}[\mathrm{dward]} \&$ Shear, C[ornelius] I[ott]}

Genera of fungi. New York, 496 p., 1931.

Clerot, I. F.

Molestias do cafeiro. Agentes physicos desfavoraveis. (Coffee plagues. Physical unfavorable agents.) Rev. Inst. Café S. Paulo, Brasil 6(62): 44, 1931.

The author discusses briefly the effects on the coffee trees of cold, heat, moisture, wounds, fungous diseases Hemileia vastatrix B. \& Br. and Cercospora coffeicola Berk. 


\section{Clinton, G[eorge] 'P[erkins]}

Ustilaginales. North Amer. Flora 7: 1-82, 1906.

\section{Cobb, $\mathbf{N}$ [athan] A[ugustus]}

Citrus-root nematode. Journ. Agric. Res. 2(3) : 217-230, 1914.

Tylenchus simithis, the cause of a root disease of sugar cane and banana. Journ. Agric. Res. 4(6) : 561-568, 1915.

A new parasite nematode found infesting cotton and potatoes. Journ. Agric. Res. 11(1) : 27-33, 1917.

A newly discovery nematode, Aphelenchus cocophilus n. sp., conected with a serious disease of the coconut palm. West Indian Bull. (Barbados) 17(4) : 203-210, 1917.

A description of the species and suggestions for control.

A new nematode Tylenchus musicola, n. sp. said to cause a serious affection of the blug goe banana in Grenada, British West Indies. West Indian Bull., 17:179-182, 1918.

A description of the organism and related species.

A newly discovered nematode (Aphelenchus cocophilus n. sp.) conected with a serious disease of the coconut palm. West Indian Bull. 17(4) : 203-210, 1919.

A description of this species which was found in the West Indies.

A newly discovered nematode, Tylenchus mahogani n. sp. connected with a disease of the mahogany tree. Journ. Parasit., 6(4) : 188-191, 1920.

Two tree-infesting nemas of the genus Tylenchus. Ann. Zool. Aplic., (Santiago, Chile.) 9:27-35. 1922.

Two new instruments for biologists. Proc. Linn. Soc. N. South Wales. 5: 157-167. 1922.

Nematodes inhabiting trees. Journ. Wash. Acad. Sci. 13:111, 1923.

The coconut industry, its economic importance and a serious disease of the coconut caused by a nematode. Journ. Wash. Acad. Sci., 13:189, 1923.

Cockerell, T[edore] $\mathrm{D}$ [ru] A[ison]

Additions to the fauna and flora of Jamaica. Journal Inst. Jamaica 1:32, 1891.

The sugar-cane fungus. Mus. Inst. Jamaica Notes No. 8: 1, 1892. 
The new coffee disease. Mus. Inst. Jamaica. Notes No. 27:1, 1892.

Report about a new disease of coffee caused by a fungus which attacks the leaves.

\section{Coker, W[illiam] $\mathbf{C}$ [hambers]}

The Clavarias of the United States and Canada. 209 p. Chapel Hill, 1923.

\& Couch, J. N.

The Gasteromycetes of the Eastern United States and Canada 201 p., Chapel Hill, 1928.

Collens, A. E.

New fungus diseases. Bull. Dept. of Agric. Trinidad. n.s. 61: $33-40,1909$.

Refers to Eutypa erumpens Massee on fallen cacao tree. Also to Diplodia cacaoicola, and $D$. maydis. Also Nectaria theobromae on exposed roots of Gliricidia maculata (Nicaraguan cacao shade) and on stems of mangoes and avocado pears. This is followed by a tabulation listing insects and fungi with brief descriptions and treatments.

Collins, $\mathbf{F}[$ rank] $\mathbf{S}$ [hipley]

Myxophyceae; in Britton N. L. The Bahama Flora p. 618$626,1920$.

\section{Colón, $\mathrm{E}[$ dmundo] $\mathrm{D}$ [imas]}

La enfermedad de las rayas amarillas. (Yellow stripe diseases.) Puerto Rico Ins. Exp. Sta. Circ. 14: 3-6, 1918.

Popular account of this disease new to Puerto Rico.

Yellow stripe of sugar cane. Porto Rico Ins. Expt. Sta. Rpt. 1918-19: 66-68, 1919.

The absorption spectrum of the chlorophyll in yellow striped sugar cane. Journ. Dept. Agric. Puerto Rico. 3(4) : 43-53, 1919.

La enfermedad de las rayas amarillas. (Yellow stripe disease.) Sugar 21:52, 1919.

A brief popular discussion.

Trabajos de investigación durante el año Fiscal 1919-20. (Research work during Fiscal year 1919-20.) Rev. Agric. Puerto Rico 6(3) : 7-14, 1921.

A review of work done at the Insular Experiment Station of Puerto Rico. 
Chemical changes in yellow striped sugar cane. Puerto Rico Ins. Expt. Sta. Ann. Rpt. 1920-21: 18-19, 1921.

Cook, Melville T[hurston]

Informe del Departamento de patología vegetal. (Report of the Department of plant pathology.) pp. 147-207. En Primer Informe Anual de la Estación Agronómica de Cuba. 190405.1906.

This is a report of the diseases of plants and the insect pest for the year 1904-1905. It contains records and descriptions of insects and diseases, citrus and some other fruits, corn, cotton, cowpea, sugar cane, pea nuts, ornamentals and other plants.

Teratología de la piña. (Teratology of the pineapple.) En Primer Informe Anual de Estación Central Agronómica de Cuba. 1904-1905: 243-246. 1906.

Deseriptions and illustrations.

Algunas agallas de Cuba producidas por insectos. (Some Cuban galls produced by insects.) En Primer Informe Anual de la Estación Central Agronómica de Cuba. 1904-1905:247-252. 1906.

Descriptions of fifteen new species.

\section{\& Horne, W[illiam] T[itus]}

Insects and diseases of tobacco.-Insectos y enfermedades del tabaco. Estación Central Agronómica de Cuba, Bull. 1, 23 p., 1905.

Descriptions and methods of control.

Coffee leaf miner and other coffee pests.-El minero de las hojas y otras plagas del cafeto. Estación Central Agronómica de Cuba, Bull. 3, 22 p., 1905.

Descriptions and methods of control.

Insects and diseases of corn, sugar cane and similar plants.Insectos y enfermedades del maíz, caña de azúcar y plantas similares. Estación Central Agronómica de Cuba, Bull. 7, $16 \mathrm{p}, .1907$.

Deseriptions and methods of control.

Insects and diseases of orange.-Insectos y enfermedades de la naranja. Estación Central Agronómica de Cuba. Bull. 9, 1-40 p., 1908.

Descriptions and methods of control.

Insects and diseases of vegetables.-Insectos y las enfermedades de las hortalizas. Estación Central Agronómica de Cuba. Bull. 12, 28 p., 1908.

Descriptions and methods of control. 
Diseases of tropical plants. Macmillan, London. 317 p., 1913. 1913.

A manual.

The status of plant pathology in Puerto Rico. Journ. Dept. Agric. Puerto Rico 7(3):3-14, 1923.

Estudio sobre la causa del matizado. (Studies on the cause of mottling.) Rev. Agric. Puerto Rico. 13(6):373--376, 1924. (Rev. Appl. Mycol. 4:378, 1924.)

A discussion of virus diseases with special reference to sugar cane mosaic.

The search for the cause of mosaic. Facts About Sugar 19(24): $570-571,1924$.

A popular paper.

Annual Report of the Division of Plant Pathology and Botany for the Fiscal year 1923-24. Puerto Rico. Ins. Expt. Sta. Ann. Rpt. 1923-24: 78-87, 1924.

Sugar-cane leaf spot in Puerto Rico. Journ. Dept. Agric. Puerto Rico 8(2): 55-57, 1924.

El pasado y el futuro de la patología vegetal. (The past and future of plant pathology.) Rev. Agric. Puerto Rico, 11: $33-39,47-52,1923$.

Popular.

Helminthosporium leaf spot of sugar cane in Puerto Rico. (Preliminary paper.) Journ. Dept. Agric. Puerto Rico 8(4):510,1924 .

Coconut fall (Preliminary paper). Journ. Dept. Agric. Puerto Rico. 8(4):12-14, 1924.

A disease of the nuts and leaves due to Thielaviopsis paradoxa.

Bacterial wilt of cosmos (Preliminary paper). Journ. Dept. Agric. Puerto Rico 8(4): 14, 1924.

Name of organism not determined.

A bacterial wilt of eggplant. (Preliminary paper.) Journ. Dept. Agric. (Puerto Rico. 8(4) : 15, 1924.

Organism not determined but proved later to be $B$. solanacearum. 
324 THE JOURNAL OF AGRICULTURE OF THE UNIVERSITY OF P. R.

\section{\& Dozier Herbert, L[awrence]}

Spraying citrus fruits in Puerto Rico. Puerto Rico Ins. Expt. Sta. Circ. 88, 23 p., 1925.

Popular.

Selección de semilla de caña. (Sugar-cane seed selection.) Rev. Agric. Puerto Rico 14(2) : 151-153, 1925.

Popular.

Enfermedades de la mancha de la hoja de la caña de azúcar. (Leaf-spot diseases of sugar cane.) Rev. Agric. Puerto Rico 14(3) : 185-187, 1925.

Popular.

Enfermedades de la raíz de la caña de azúcar. (Sugar-cane root diseases.) Rev. Agric. Puerto Rico. 14(4) : 245-246, 1925.

Popular.

Peligros de la importación de plantas exóticas. (The dangers of importing exotic plants.) Rev. Agric. Puerto Rico. 14(5): 315-318, 1925.

Popular.

El salcocho en los semilleros de tabaco. (Damping-off in tobaceo seed beds.) Rev. Agric. Puerto Rico. 15(4): 187188, 1925.

Refers to Phytopthora nicotianae.

Esterilización de terrenos para semilleros. (Soil sterilization of seed beds.) Rev. Agric. Puerto Rico 15(5):239-240, 1925. Popular.

Leaf spot disease of sugar cane. Facts About Sugar. 20(10): 234, 1925.

Popular.

Relationship of cane variety to diseases. Journ. Dept. Agric. Puerto Rico. 9(4): 277-281, 1925.

A discussion of the control of diseases by the use of resistant varieties.

Enfermedades de las hojas de tabaco. (Leaf diseases of tobacco.) Rev. Agric. Puerto Rico. 15(6) : 282, 1925.

Popular. Refers to Cercospora nicotianae. 
Chlorosis de la piña. (Pine apple chlorosis.) Rev. Agrie. Puerto Rico. 15(6): 296-297, 1925.

Popular.

Enfermedades del algodón en Puerto Rico. (Cotton diseases in Puerto Rico.) Rev. Agric. Puerto Rico. 15(6):300-301, 1925.

Popular.

Present knowledge of mosaic disease. Journ. Dept. Agric. Puerto Rico. 8(2):50-54, 1925. (Int. Sugar Journ. 27 (324) : 647-648, 1925 .

Popular.

Studies on the eytology of sugar-eane mosaic. Phytopathology (Abstract) 15(1): 45, 1925.

Esterilización de terreno para semilleros. (Soil sterilization of seed-beds.) Rev. Agric. Puerto Rico. 15(5) : 239-240, 1925. 1925.

Popular.

El dominio del matizado de la caña de azúcar. (The control of sugar-cane mosaic.) Rev. Agric. Puerto Rico. 14(1):7-9, 1925. (Facts About Sugar 20(30):67-68, 1925. Rev. Agric. Com. \& Trab. Cuba $23: 23-24,1925$.)

A popular diseussion of the disease in Puerto Rico.

Histology and eytology of sugar-cane mosaic. Journ. Dept. Agr. Puerto Rico, 9(1):5-27, 1925. (Rev. Appl. Mycol. 5:387388, 1925. Rev. Agric. Puerto Rico 15(6) : 291-293, 1925.)

The author gives a review of the literature on this phase of the subject and the results of his own studies. The chlorotic areas are slightly thinner than the green areas. The green areas are the sameas a healthy leaf of the same age. The intracellular bodies are present but diffieult to find. Chloroplasts are smaller and fewer in chlorotic than in healthy cells.

Sugar production and cane diseases. Facts About Sugar 20 (45) : 1068-1069. 1925. (Rev. Appl. Mycol. 5: 187, 1925. Rev. Agric. Puerto Rico. 15(6): 273-276, 1925.) Popular.

El mosaico de la caña de azúcar en Puerto Rico. (Sugar-cane mosaic in Puerto Rico.) Rev. Agric. Puerto Rico. 17(5): 6-13. 1926. (Facts About Sugar 22(9): 203, 1927. Rev. Appl. Mycol. 6: 318-319, 1926.)

Popular. 
Photo-synthesis of the sugar-cane plant. Journ. Dept. Agric. Puerto Rico. $10(3-4): 239-242,1926$. (Rev. Appl. Mycol. 7: 198, 1926.)

The author reviews the literature on this phase of the subject and makes comparative studies of sugar-eane mosaic with his previous studies on peach yellow and little peach. In the case of sugar cane the chlorotic areas do less photosynthetic work than the green areas but the translocation of earbohydrates is normal. In the case of peach yellows and little peach the translocation of earbohydrates is almost or completely inhibited.

Report of the Division of Botany and Plant Pathology. Puerto Rico Ins. Expt. Sta. Ann. Rpt. 1924-25 : 98-107, 1926.

Epiphytic orchids a serious pest on citrus trees. Journ. Dept. Agric. Puerto Rico. 10(2): 5-9, 1926.

Ionopsis utricularioides and Leochilus labiatus killed large branches on trees.

The eye-spot disease of sugar cane. Journ. Dept. Agric. Puerto Rico 10(3-4) : 207-227, 1926.

The history, distribution and symptoms of the disease and the organism (Helminthosporium sacchari) with the results of laboratory and field studies.

Informe de la Estación Experimental Insular, Puerto Rico, 1925-1926. (Annual Report of the Insular Experiment Station, Puerto Rico, 1925-26.) In the Director's Report, p. 44-46, 1927.

Experiencias con la gomosis de la caña de azúcar. (Experiments on the gumming disease of sugar cane.) Rev. de Agric. Puerto Rico. 18(5): 281, 1927.

Popular.

Sugar cane gummosis. Ref. Book Sugar Indus. of the World. 6(6) : 72-73, 1928.

Popular.

The effect of mosaic on the content of plant cell. Journ. Dept. Agric. Puerto Rico. 10(3-4) : 229-238, 1926. (Rev. Appl. Mycol. 7: 197-198, 1928.)

The author gives a review of the literature and the results of his own studies. The chlorotic areas are indistinct in the very young leaves. They become distinct with exposure to light. Later the chlorotic areas tend to become green. The chloroplasts are smaller and fewer in number than in the green areas, but increase in size and 
number with age. The chlorotic areas increase in size as a result of cell growths and cell division and by the encroachment of the virus on the surrounding cells. The nuclei are usually enlarged and deformed.

Some effects of mosaic on the contents of the cells. Phytopathology (Abstract) 17(1):57, 1927.

Report of the Division of Botany and Plant Pathology. Puerto Puerto Rico Ins. Expt. Sta. Ann. Rpt. 1927-28: 24-25, 59-66, 1929.

The gummosis of sugar cane (first paper.) Journ. Dept. Agric. Puerto Rico, 12(3): 143-177, 1928.

The author gives a discussion of the history, geographical distribution, origin, spread, symptoms, eausal organism, the results of field tests, and inoculation experiments to determine resistance and suseeptibility of varieties.

Annual Report of the Insular Experiment Station, Puerto Rico, 1926-27. In the Director's Rept. p. 29, 34, 37, 1929.

The eye spot disease of sugar cane (Helminthosporium sacchari). Plant. \& Sugar Mafg. 83:101-102, 1929.

The dry top rot of sugar cane. Ref. Book. Sugar Ind. World. $7: 32,1929$.

Popular.

Tres enfermedades de la caña de azúcar encontradas recientemente en Puerto Rico. (Three diseases of sugar cane recently found in Puerto Rico.) Rev. Agr. Puerto Rico. 22(7): 15-16, 39, 1929.

A popular paper on pokkahbong (Fusarium moniliforme,) brown stripe (Helminthosporium stenospilum) and red stripe (Phytomonas rubilineans.

Life history of Ligniera vascularum (Matz) Cook (Formerly known as Plasmodiophora vascularum). Journ. Dept. Agric. Puerto Rico. 13(1): 19-29, 1929.

A description of the disease. The author transfers the species from Plasmodiophora to Ligniera.

The gummosis of sugar cane (Second paper). Journ. Dept. Agric. Pnerto Rico 13(2) : 73-76, 1929.

Continuation of the first paper.

The development of the spores of Plasmodiophora vascularum Phytopathology (Abstract) 19(1):91-92, 1929. 
The effect of some mosaic diseases on the cell structure and the chloroplasts. Phytopathology (Abstract) 20(1):142, 1930.

The effect of some mosaic diseases on cell structure and on the chloroplasts. Journ. Dept. Agric. Puerto Rico. 14(2):69101, 1930.

The author gives a review of the literature and the result of his own studies which are a continuation of previous studies and in which he has used sugar cane, canna, tobacco, tomato and cowpea. The chlorotic areas are thinner than the green areas. The active agent inhibits the differentiation of the cell structure and of the chloroplasts. The earlier the attack, the greater the inhibition. The active agent does not penetrate the various parts of the leaf equally. The result is the chlorotic areas and variations in cell differentiation. There is no reason to believe that structure and development of chloroplasts are modified by the virus. It is a true case of inhibition. The development of cell structure is permanently checked but the chloroplasts of the chlorotic areas increase in size and number.

La situación actual en enfermedades de la caña de azúcar en Puerto Rico. (The present situation on sugar cane diseases in Puerto Rico.) Rev. Agric. Puerto Rico. 24.(12) : 227-231, 1930 .

Brief popular notes on disease of sugar cane in Puerto Rico with recommendations for their control.

Gomosis de la caña P.O.J. 2878 en Puerto Rico. (Gummosis of P.O.J. 2878 cane in Puerto Rico.) Rev. Agric. Puerto Rico. 24(3) : 102, 1930. (Fact About Sugar, 26(6): 257, 1931.)

A strain of Bacterium vascularum attacking the sugar cane variety P.O.J. 2878, which is considered immune.

Report of the Division of Botany and Plant Pathology. Puerto Rico. Ins. Expt. Sta. Ann. Rpt. 1929-30: 93-109, 1931.

Undescribed symptoms of mosaic in Puerto Rico tobaceo. Phytopathology (Abstract) 21(1):117, 1931.

A brief description.

Distribución geográfica de las enfermedades de la caña de azúcar (Geographical distribution of sugar-cane diseases). Rev. Agric. Puerio Rico 25(5):170-172, 1930. (Facts About Sugar 26(1):24-26, 1931.)

A chart is given with explanatory notes, showing the distribution of cane diseases throughout the world. 
Enfermedades de la caña de azúcar en Puerto Rico. (Sugar-cane diseases in Puerto Rico.) Ins. Expt. Sta. Puerto Rico. Cire. 94, 45 p., 1931.

Deseriptions of the important diseases of sugar cane in Puerto Rico with recommendations for their control.

Undescribed symptoms of mosaic in Puerto Rico. Phytopathology (Abstract) 21(1):117, 1931.

New virus diseases in Puerto Rico. Phytopathology (Abstract) $21(1): 124,1931$.

Six unreported virus diseases are briefly described. 1. A mosaic of Crotalaria striata; 2. A rare mosaic of Commelina longicautis; 3. A bunchy-top of Carica Papaya; 4. A variegation of Abutilon hirtum; 5. A variegation of several species of sida; 6 . A mottling of mulbery (Morus album.)

Some undescribed symptoms of mosaic in Puerto Rican tobacco. Journ. Dept. Agric. Puerto Rico 15(2) : 189-191, 1931.

The author gives the results of cross-inoculation experiments and of studies on the histology of leaves of various ages. The results of these later studies are: (1) When leaves are inoculated there is an inhibition of the development of cell strueture and chloroplast; (2) When chlorotic areas are formed on leaves with fully developed tissues there is no change in cell structure but the growth of the chloroplasts was inlibited; (3) That the enlargement of the mosaic areas on young leaves is due to cell division and growth and not to invasion of surrounding cells by the virus.

The leaf spots of tobacco; an after symptom of mosaic. Journ. Dept. Agric. Puerto Rico. 15(2): 183-187, 1931.

This appears to be the same as the spot deseribed by Mayer in 1886 and which Iwanowski and Polowzoff described later as "Pokenkrankheit'. The author believes these spots to be a late symptom of tobaceo mosaic.

New virus diseases of plant in Puerto Rico. Journ. Dept. Agric. Puerto Rico. 15(2): 193-195, 1931.

This paper records mosaic on Adcnoropium gossypifolizm and Ipomoea Nil.

The effect of mosaic on cell structure and chloroplasts. Journ. Dept. Agric. Puerto Rico. 15(2) : 177-181, 1931.

The author reports the result of studies of the effect of mosaic on the cell strueture and chloroplasts of Capsicum annuum, Crotalaria striata, Carica papaya, Eucharis amasonica and a hybrid Amaryllis. The results confirm the author's previous opinion that the effect of many viruses is inhibitory. 
La roña de la toronja en Puerto Rico. (Sphaceloma Fawcetti.) (Grapefruit scab in Puerto Rico. Sphaceloma Fawcetti.) Ins. Expt. Sta. Puerto Rico. Cire. 92, 15 p., 1931. Popular.

Informe Anual de la Sección de Botánica y Fitopatología. En el Informe Anual del Comisionado de Agricultura y Comercio de Puerto Rico, 1930-31. (Annual Report of the Division of Botany and Phytopathology. In the Annual Report of the Commissioner of Agriculture and Commerce of Puerto Rico, 1930-31.) p. 127-129, 1931.

Annual Report of the Division of Botany and Plant Pathology. In the Annual Report of the Insular Experiment Station, Puerto Rico, 1928-29: 60-66, 1932.

Report on the international survey of the diseases of sugar cane. 4th Congrèss Int. Soc. Sugar Cane Tech. 1932, Bull. 128. 15 p., 1932.

Data on the geographical distribution of diseases of sugar cane. Compiled from data furnished by plant pathologists.

Thielaviopsis paradoxa, an important disease of sugar cane. Journ. Dept. Agric. Puerto Rico. 16(2) : 205-211, 1932.

A review of our knowledge of this fungus with a discussion of its behavior in Puerto Rico.

Rotting of sugar-cane cuttings in Puerto Rico. Phytopathology (Abstract) 22(1):7, 1932.

The rotting is due to Thielaviopsis paradoxa.

Gummosis of sugar cane. Proc. 4th Cong. International Soc. Sugar Cane Tech. 1932. (Facts About Sugar (Abstract) 27: 260-261, 1932.)

The disease in Puerto Rico. A discussion of strains.

Melanconium sacchari, parasite or saprophyte. Proc. 4th. Cong. Internat. Soc. Sugar Cane Tech. 1932. (Facts About Sugar (Asbtract) 27(6):261, 1932.)

A brief discussion of the writer's studies. The organism is a weak parasite.

\section{\& Morales Otero, Pablo}

Gum-producing organism in sugar cane. Journ. Dept. Agric. Puerto Rico. 17(4): 271-286, 1933.

The history of this organism with the results of additional laboratory and inoculation studies with 36 strains. 
Parasitism of Marasmius sacchari, Wakker. Proc. 4th Int. Cong. Soc. Sugar Cane Technologists. 1932.

Marasmins sacchari, a parasite on sugar cane. Journ. Dept. Agric. Puerto Rico, 16(2): 213-226, 1932.

Rotting of sugar-cane cuttings in Puerto Rico. Phytopathology 22: 7, 1932. (Facts About Sugar 27:259-260, 1932.)

Action inhibitrice du virus des mosaïques sur l'evolution cellulaire. (Inhibitary action of mosaic virus in the cellular evolution.) Deuxiéme Congres International de Pathologie Compáre. p. 1-8, 1932.

This paper is a résumé of some of the works of the author published in The Journal of the Dept. of Agric. Puerto Rico."

The gummosis of sugar cane. Int. Soc. of Sugar Cane Tech. Bull. 35, 12 p., 1932.

A very brief review of this disease.

White spot of pineapple. Journ. Dept. Agric. Puerto Rico. $17(4): 311-313,1933$.

A review of the literature. The writer found that the disease in Puerto Rico was due to climatic conditions.

The pineapple disease of sugar cane in Puerto Rico. Journ. Dept. Agric. Puerto Rico. 17(4) : 305-309, 1933.

The results of studies on Thielaviopsis paradoxa.

This paper was published in La Hacienda 32.(5): 177-178, 1937 (without the consent or approval of the Station or author) under the incorrectly translated title of "Una enfermedad de la caña de azúcar en Puerto Rico", and from La Hacienda in Brasil Acucareiro $9(5)$ : 344-345, 1937.

Patho-anatomy of roots attacked by nematodes. Journ. Dept. Agric. Puerto Rico 17(4) : 315-319, 1933.

A partial review of the literature, descriptions of the injuries and comparisons with similar injuries due to other causes.

Informe Anual de la Sección de Botánica y Fitopatología. En el Informe Anual del Director de la Estación Experimental Insular, 1931-32 (Annual Report of the Division of Botany and Phytopathology. In the Annual Report of the Director of the Insular Experiment Station of Puerto Rico, 1931-32). p. 36-37, 1933.

Virus diseases of plants. Sci. Mo. 36(4) : 355-359, 1933. Popular. 
Informe Anual de la Sección de Botánica y Fitopatología. En el Informe Anual de la Estación Experimental de Puerto Rico, 1932-33. - Annual Report of the Division of Botany and Phytopathology. In the Annual Report of the Insular Experiment Station, Puerto Rico, 1932-33). p. 76-91, 1934.

Annual Report of the Division of Botany and Plant Pathology. In the Annual Report of the Agricultural Experiment Station of Puerto Rico, 1933-34: 125-141, 1935.

Relation of insect injuries and root diseases in sugar cane. Phytopathology (Abstract) 25(1):12, 1935.

Root diseases of sugar cane in Puerto Rico. Part I. Normal structure of roots. Part II. A new parasitic fungus in the roots of sugar cane. Journ. Agric. Univ. Puerto Rico. 19 (2) : 121-128, 1935.

The author deseribes the normal structure of healthy sugar-cane roots and gives account of a new parasitic fungus observed in stained sections of sugar-cane roots. The symptoms of its presence are discussed and a Latin diagnosis is given of the fungus Olpidium sacchari n. sp.

Annual report of the Plant Pathologist for the fiscal year of 1934-1935. In the Annual Report of the Agricultural Experiment Station of Puerto Rico. p. 22-29, 1937.

Enfermedades nuevas o poco conocidas de la caña de azúcar en las Antillas. Rev. Agric. Puerto Rico. (Suppl. No. 1) Memoir. Assoc. Sugar-Cane Tech. Puerto Rico, 1935-36:5$13,1936$.

Short descriptions of several new diseases of minor importance.

Phloem necrosis in the stripe disease of corn. Journ. Agric. Univ. Puerto Rico 20(3) : 685-688, 1936.

Examination of corn affected with white stripe disease in Puerto Rico showed phloem necrosis to be invariably present, accompanied by a thickening of the walls of the epidermal cells, fibrous cells and sheath cells. The chloroplasts in the cells of healthy plants were larger than those in the chlorotic parts of affected plants and in severely affected regions the nuclei showed desintegration.

Annual Report of the Division of Botany and Plant Pathology. In the Annual Report of the Agricultural Experiment Station of Puerto Rico, 1935-36:39-46, 1937. 


\section{Otero, José I[dilio], López Domínguez, F[rancisco]}

\section{A[ntonio] et.al.}

History of the first quarter of a century of the Agricultural Experiment Station at Río Piedras, Puerto Rico. Bull. 44, 123 p., 1937.

This history of all the work of all the Divisions of the Station contains a brief review of the work in botany and plant pathology on pages $68-73$.

\section{Cook, O[rator] $\mathbf{E}$ [uller]}

Leaf-cut or tomatosis. a disorder of cotton seedling. U.S.D.A. Cire. 120: 29-34, 1913.

This is a brief discussion of a disease which may be due to a virus.

Branchysm, a hereditary deformity of cotton and other plants. Journ. Agrie. Res. 3:387-399, 1915.

It has not been proved that this is a virus disease but it has many of the characteristics of this group of plant diseases.

Malformation of cotton plants in Haiti. A new disease named smalling or stenosis causing abnormal growth and sterility. Journ. Heredity 14(7) : 323-335, 1923.

The author describes a disease which he calls "smalling" or "stenosis". Certain characters resemble some of the virus diseases but it is neither contagious nor infectious.

Acromania or "crazy-top" a growth disorder of cotton. Journ. Agric. Res. 28(8): 803, 1924.

It is not known that this disease is caused by a virus. The author describes the symptoms of this disease and also a brachysm, tomosis, hybosis, eitosis and stenosis.

\section{Cook, W[alter] R[obert] Ivimey}

On the life history and systematic position of the organism of the diry top rot of sugar eane. Journ. Dept. Agric. Puerto Rico. 16(14) : 409-418, 1932.

Attributes the disease to Amoebosporum vascularum n. sp. and $A$. vascularum $\mathrm{n}$. $\mathrm{sp}$.

Cooke, M[ordecai] C.

Mycographia seu Icones Fungorum. I. Discomycetes. London $120 \mathrm{p} ., 1875$.

Exotic fungi. Grevillea 9:10-11, 1880; 9:97-10, 1881; 10 : $123,1882$.

Taxonomic; records Uredo oxalidearum Cke. and Sphaerella psammisiae Cke.; Pellicularia Koleroga Cke.; Leptostroma discoidea Cke.; Forula Sphaerolla Cke.; Stilbum flavidum Cke.; Sphaerella coffeicola Cke. as new species found in Venezuela. 
334 THE JOURNAL OF AGRICULTURE OF THE UNIVERSITY OF P. $R$.

Xylaria and its allies. Grevillea 11:81-94, 1883.

Hypoxylon and its allies. Grevillea 11:121-140, 1883.

Notes on Hypocreaceae. Grevillea 12:77-83, 1884.

Taxonomic; records Hypocrea Fendleri Berk. \& Curt. from Venezuela.

Praecursores ad monographiam Polyporum. Grevillea 15:19$27,1886$.

Taxonomic: records Polyporus Venezuelle Berk. \& Curt., Polystictus coryophyllaceous Berk. \& Curt., Poria geogena, Berk. \& Curt., P. flavipora Berk. \& Curt., P. porotheloides Berk. \& Curt., from Venezuela.

Two coffee diseases. Pop. Sci. Rev. 15: 161.

Two coffee diseases. Pop. Sci. Rev. No. 59:135.

The coffee disease in South America. Linn. Soc. Journ. Bot. $18: 361-467,1881$.

Description of the disease known in Venezuela as "Candelilla" and "Iron stain". The organisms eausing this coffee leaf disease are Stilbum flavidum Ck, and Sphaerella coffeicola.

Some exotic fungi Grevillea 16:121, 1888.

Taxonomic, records Marasmius cinctus Berk. from Venezuela.

Costa Lima, Angelo da

A propósito de una comunicacao do Dr. Puttemans sobre o mosaico da cana de assucar. (About a letter from Dr. Puttemans related to sugar-cane mosaic disease.) Characas e Quintaes 34: 30-42, 1926.

(Mosaic and thrips in Brazil.) Bol. Agric. Ind. Comm. Brazil. $2: 38-41,1926$.

The writer believes that Thrips minuta var. Puttemansi is the vector for mosaic of sugar cane.

Relatorio sobre a doenca dos cafeeiros de Pernambuco. (Report on coffee diseases in Pernambuco.) Secret. Agr. Com. Ind. Viacao e Obras Pub. 27 p., 1928.

Costa, A. S. \& Krug; H. P.

Eine durch Ceratostomella hervorgerufene Welkekrankheit der Crotalaria juncea in Brasilian. (A wilt disease of Crotalaria juncea in Brazil caused by Ceratostomella.) Phytopath. Zeitschr. 8(5) : 507-513, 1935.

Deseription and diagnosis of the fungus Ceratostomella fimbriata as the cause of a wilt disease of Crotalaria juncea in Brazil. 
Cousins, H. H., \& Sutherland, J. B.

Plant diseases and pests. Report of the Secretary of the advisory committee on the banana industry. Dept. Sci. Agric. Jamaica Ann. Rpt. 1929: 15-19, 1930.

\section{Cowgill, H[orace] $\mathrm{B}$ [ranson]}

Report of the Plant Breeder. Puerto Rico. Ins. Expt. Sta. Rpt. 1917-18 : 78-104, 1918.

\section{Crawley, J[osiah] T[homas]}

Control of the mosaic disease in Cuba. Facts About Sugar 2: 554-555, 1927. (Rev. Appl. Mycol. 6: 752, 1927.)

Gives results of roguing and seed selection in sugar cane.

\section{Croker, Ricardo}

El peligro de las enfermedades del cafeto. (The danger of coffee diseases.) Rev. Cafetera de Colombia 5(48-50) : 16761777, 1933.

Brief notes on coffee berry diseases. 1. Berry spot (Cercospora coffeicola). 2. The berry black spot (Colletotrichum coffeanum). 3. The berry brown spot (Colletotrichum coffeanum).

\section{Cross, W[illiam] E[rnest]}

The Kavangerie cane. Louisiana Planter \& Sugar Manuf. 63: 397-399, 1919.

Kavangerie proved to be immune. The author also gives a discussion of it desirable and undesirable qualities.

The Java-Argentine seedling sugar canes. Louisiana Planter. 66 : 184, 1921.

Resistance to mosaic.

La Estación Experimental Agrícola de Tucumán. Su contribución a la Industria Azucarera de Puerto Rico. (The Agricultural Experiment Station at Tucumán. Its contribution to the Sugar Industry of Puerto Rico.) Rev. Indus. Agric. Tucumán, 13 (11-12) : 207-211, 1923.

A controversy.

\section{\& Fawcett, G[eorge] L[orenzo]}

La enfermedad del mosaico en Luisiana. (The mosaic disease in Louisiana.) La Industria Azucarera, Argentina 30(376) : 975-979, 1924.

Mosaic resistant Java canes in Tucumán. Facts About Sugar. $19: 250-251,1924$.

Popular. 
Present needs in cane disease control. A rejoinder to Mr. A. H. Lee. Int. Sugar Journal. 27:26-31, 1925.

The author states that the plant pathologists are responsible for the introduction and spread of sugar-cane diseases rather than the Government Experiment Stations and individuals. He gives some data concerning downy mildew, Fiji disease and mosaic.

Ensayos y observaciones relativas al efecto del mosaico sobre los rendimientos culturales de las variedades P.O.J. 36, 213 y 2725. (Experiments and observations relative to the effect of mosaic on the cultural yields of the varieties. P.O.J. 36, 213, and 2725.) Rev. Ind. Agric. Tucumán, 24(3-4) : 57-76, 1934.

Studies on cultural yield of sugar-cane varieties. Details given in tabulated form.

Cañas resistentes al mosaico en Tucumán. (Canes resistant to mosaic at Tucumán.) Industria Azucarera, Argentina 30 (370) : 660-661, 1924. (Louisiana Planter \& Sugar Manuf. 73: 468-469, 1924. Facts About Sugar 19(11) : 250-261, 1924. Int. Sugar Journ. $27(124)$ : 551, 1925.)

Popular. Deterioration of certain varieties believed to be due to mosaic. Controversy.

El mosaico de la caña en Cuba. (Sugar-cane mosaic in Cuba.) Rev. Agric. Com. \& Trab. Cuba 7(4): 9-10, 1924.

Popular.

Enfermedades de la caña de azúcar en Tucumán. (Sugar-cane diseases in Tucumán.) Sugar $27(2)$ : 103-104, 1925.

La importación de la caña Kavangire en Puerto Rico. (Kavangerie cane importation into Puerto Rico.) Mundo Azucarero 14(5):145-149, 1926. (Planter \& Sugar Manuf. 77: $327-330,1926$.

Controversial.

The P.O.J. 979 variety in Tucumán. The Planter \& Sugar Manuf. 78(1) : 8, 1927.

\section{Cruz, Francisco \& Bruner, Stephen C[ole.]}

Una visita de inspección a la zona de tabaco en Cabaiguan. (An inspection of the tobaceo region of Cabaiguan.) Rev. Agric. Comercio y Trab. Cuba 13(10):34-38, 1931.

A variety known as Puerto Rico which is probably Nicotina lanceolata is very susceptible to mosaic. A small planting of $N$. havanensis was almost free from the disease. 
Cubillos, Iuis A.

Cafetos enfermos. (Diseased coffee trees.) Rev. Cafetara de Colombia 2(10) : 323-324, 1929.

Brief note in which the author states that root lesions caused by implement and over production may determine the causes of the diseases which were under observations.

Cunningham, H. S.

Report of Plant Pathologist. Rept. Dept. Agric. Bermuda. For the year $1928: 26-28,1929$.

Records Cercospora musarum (Black tip of banana) and Septoria blight of celery, Cerotelinm fici of figs, Alternaria solani of potatoes, Septoria of tomato.

Report of the plant pathologist. Bermuda Dept. Agric. 1929: 26-31, 1930.

Report of the plant pathologist. Bermuda Dept. Agric. Ann. Rpt. $1930: 33-39,1931$.

Curruthers, J. B.

Cacao canker. Bull. Dept. Agric. Trinidad 9(64):30-31, 1910.

\section{Dalbey, Nora E[lizabeth]}

Corn disease caused by Phyllachora graminis. Phytopathology $7(1): 55-57,1917$.

Phyllachora as the cause of a disease of corn, and a general consideration of the genus Phyllachora. Trans. Ill. Acad. Sci. $10: 230-248,1917$.

\section{Dalmau, Luz MIaría}

Observations on mycologic technique with particular reference to pathogenic fungi. Puerto Rico. Journ. Pub. Health. 5 (3) : 302, 1929.

\section{Damph, Alfonse}

No existe en México el mal de Panama del plátano. (The Panama disease of the Plantain does not exist in México.) Bol. Mens. Ofic. Def. Agric. Estados Unidos Mexicanos. 2 (10-11) : 638-642, 1928 .

Bibliografía de los principales trabajos relativos al mosaico de la caña de azúcar que se han publicado a partir del descubrimiento de la enfermedad hasta el año 1929. (Bibliography of the leading articles related to sugar-cane mosaic published from the discovery of the clisease to the year 1929.) Bol. Mes. (México) Oficina Federal Defensa Agric. 3(5-8): 186-236, 1929. 
338 THE JOURNAL OF AGRICULTURE OF THE UNIVERSITY OF P. $R$.

México: Panama disease of bananas. Int. Bull. Plant Proct. 6 (2) : 24, 1932.

The disease is reported in the State of Tamaulipas. The organism is given as Fusarium cubense var. inodoratum (F. oxysporum).

Dash, J. Sydney

Report on the entomological and mycological work. Banana. Barbados Dept. Agric. Rept. 1913-14:43-45, 1915.

Wilt disease of sugar cane. Barbados Dept. Agric. Ann. Rpt. 1915-1916, 1916.

Diseases of musaceous crops. Brit. Guiana Sci. \& Agric. Rpt. 1927 : 5-7, 1927.

\section{Davidson, Ross W[allace]}

Notes on tropical rusts with descriptions of two species. Mycologia 24(2) : 221-228, 1932.

Deseription or mention of 14 species.

\section{Davis, Robert L[esley]}

P.O.J. 2878 in Puerto Rico. Sugar News. 10(5) : 342-343, 1929.

Studies on mosaic.

Java-Barbados hybrids in Porto Rico. Planters \& Sugar Manuf. 83(5) : 83-85, 100; (6) : 103-104; (7) : 123-125, 1929. (Rev. Appl. Mycol. 9(2): 132, 1930.)

Studies of varieties of sugar cane resistant to mosaic.

Mayagüez 3, 7 and 42-Three cane varieties immune to mosaic. Puerto Rico Agric. Expt. Sta. Notes 52, 2 p., 1930.

The three varieties Mayagüez 3, 7 and 42 produced from crossing POJ 2725 and SC 12(4) appeared to be resistant to mosaic.

Report of the Plant Breeder. Porto Rico Agric. Expt. Sta. Rpt. 1931 : 13-22, 1932.

Mayagüez 28, 49 and 63, three sugar-cane varieties commercially resistant to mosaic. Porto Rico Agric. Expt. Sta. Notes 61, 6 p., 1932.

A report on the behavior of these and other varieties.

Sugar-cane crosses with Kassoer, selfs. Trans. Fourth Intern. Congress Soc. Sugar-Cane Tech. 1932. (Facts About Sugar (Abstract) 27(5):218, 1932.

Tests with crosses of Kassoer to determine susceptibility to mosaic disease of sugar cane. 
Sugar-cane seedling mosaic elimination. Trans. Fourth Intern. Congress Soc. Sugar-Cane Tech. 1932. (Facts About Sugar (Abstract) 27(5):219, 1932.)

Experiments to determine the optimum spacing and planting methods for obtaining data on the reaction of sugar-cane seedling to mosaic. Under Mayagüez (Puerto Rico) conditions, it was found that mosaic will spread in 8 months for a distance of 50 feet along a single row of a susceptible variety.

Report of the Plant Breeder. Porto Rico Agric. Expt. Sta. Ann. Rpt. 1932: 11-17, 1933.

Report of the work done during the year with mosaic-resistant seedlings.

\section{Dearness, John}

New or noteworthy North American fungi. Mycologia 9(6): 345-364, 1917.

This report includes the description of the fungi Asterina ( $A s$ terella) fumagina Dearn. \& Barth. sp. nov. on Panicum latifolium and on Canna indica L. Both from Puerto Rico.

\section{Delacroix, [Edward] G[eorges]}

Quelques espéces nouvelles. (Some new species.) Bull. Soc. Mycol. France 13: 114-127, 1897.

Taxonomic: records Vermicularia Geayana, Chaetomium varium from Venezuela.

(Some parasitic fungi of tropical cultivated plants.) Bull. Soc. Mycol. France 21(3) : 24-37, 1905.

Depons, F.

Voyage a la partie orientale de terre ferme dans l'Amérique $\mathrm{Me}$ ridionale, fait pendant les anées 1801-02-03 et 04. (Trip. made to the eastern part of the continent of South America during the years 1801-02-02 and 04.) Paris, Fain \& Co. 194 p., 1806.

d'Herelle, F. H.

Maladie du caféier au Guatemala. (Coffee diseases in Guatemala.) Bull. Soc. Mycol. France 25(3) : 171-185, 1909.

Description of a disease of coffee occurring in Guatemala. It is attributed to the fungus Phthora vastatrix n. $\mathrm{sp}$.

Una nueva enfermedad del café. (New coffee disease.) Ann. Muc. Nac. San Salvador 4(28) : 182-189, 1910.

Diedicke, $\mathrm{H}$.

Die Gattung Septoria. (The genus Septoria.) Ann. Mycol. $10: 478-487,1912$. 


\section{Dietel, Paul}

Bemerkungen zu der uredineenflora Mexicos (Observations on the Uredinales of Mexico.) Hedwigia 37:204-211, 1898.

\section{\& Neger, $\mathbf{F}$}

Uredinaceae chilensis I-III. Engl. Bot. Jahrb. 22 : 348-358; 24 : $153-160 ; 27: 1-16,1896-99$.

Uredineae brasilenses a cl. E. Ule lectae I-II. Hedwigia 36: $26-27 ; 38: 248-259,1897-1899$.

Uredinaceae paraenses. Bol. Mus. Goeldi 5: 262-267, 1909.

\section{Dodge, B[ernard] O[gilvie]}

The life history of Ascobolus magnificus. Mycologia 12(15): 115-134, 1920.

Dranert, Friedr. M.

Bericht über die krankheit des Zuckerrohres. (Report on sugarcane disease.) Zeitscr. Parasitenkunde 1:13-17, 1869.

Notes on sugar-cane gummosis.

Weitere notizen über die krankheit des Zuckerrohres. (Further notes on the sugar-cane disease.) Zeitschr. Parasitenkunde $1: 212,1869$.

\section{Drost, A. W.}

Verslag over het jaar 1910 (Annual Report for the year 1910.) Dept. van den Landbuow in Suriname, p. 21, 1910.

De Surinaamsche Panamaziekte in de Gros Michel Bacoven. (The Suriname Panama disaese of the Gros Michel banana.) Dept. Landb. Suriname. Bull. 26:4-40, 1912.

The Surinam Panama disease of the Gros Michel banana, 1912. (Trans. by S. F. Ashby.) Bull. Dept. Agric.. Jamaica. n, s. 2(6) : 128-149, 1913.

Drechsler, $\mathrm{C}$.

Species of Helminthosporium distinct from Helminthosporium saccharti, causing brown stripe of sugar cane. Phytopathology (Abstract) 18(1): 135-136, 1928.

A description $H$. stenospilum n. sp.

\section{Duby, Jean Etienne}

Notice sur quelques cryptogames nouvelles des environs de Bahia.

(Brésil) (Noles on some new fungi in the vicinity of Bahia, Brazil.) Mem. Soc. Phys. \& Hist. Nat. Geneva 7:405-413.

\section{Dunlop, W. R.}

Panama disease of banana. Imp. Dept. Agric. BWI. Circ. 1920. Popular. 


\section{Duque, Juan Pablo, \& Patarroyo B., Alfonso}

Paloteo pernicioso de las ramas del cafeto. (Coffee die back.) Rev. 'Cafetera de Colombia 5(54-57) : 1760-1763, 1933.

Description of this disease of general oceurrence in Kenya, Tanganyika and Uganda. The authors state that the cause is not due to a specific fungus but to the association of different species. No curative methods are known so far, but preventive measures are given.

\section{Durand, Glías $J$.}

New or noteworthy Geoglossaceae. Mycologia 13(3) :184-187, 1921.

Taxonomic: Notes from species of Brazil, Cuba and Bermuda.

D'Ultra, Gustavo, R. P.

Sobre as anguillulas do cafeiro. (On coffee nematodes.) Bol. Inst. Agric. S. Paulo, Campiñas 10(5) : 1899.

Pragas do cafeiro. (Coffee diseases and pests.) Bol. Agric. Sec. Agric. Com. \& Obras Pub. S. Paulo 15(1) : 1-14, 1914.

Popular discussion on the coffee leaf miner (Leucoptera coffeella), sooty molds, the coffee seale (Coccus viridis Green) and a warning to coffee growers about the fungus Hemileia vastatrix which has not been reported yet in the Western Hemisphere.

Cafeiros doentes. (Diseased coffee trees.) Bol. Agric. Sec. Agric. Com. \& Obras Pub. S. Paulo 16(12) : 1037-1038, 1915.

Popular account about the coffee leaf miner (Leucoptera coffeella), the green scale (Coccus viridis) and sooty molds. Gives recommendations for control.

Molestias do eacáuero (Cacao diseases.) Bol. Agric. Sec. Agric. Com. \& Obras Publ. S. Paulo 18(9) : 693-711, 1917.

Earle, F[ranklin] S[umner]

Some fungi from South America. Bull. Torrey Bot. Club 26: 631-634, 1899.

Some fungi from Puerto Rico. Muhlenbergia 1:10-17, 1901.

Report on a trip to Jamaica. West Indian Bull. 4(1) : 1-8, 1904. Reprint of report in Journ. of the N. Y. Bot. Garden 4:1-10, 1902.

Diseases of logwood, cocoa-nut, cassava, etc., at Jamaica, West Indian Bull. $4: 278,1903$. (Journ. New York Bot. Gard. 4: 1-10, 1903.)

Banana leaf-blight, in Report of a trip to Jamaica. Journ. New York Bot. Gard. 4: 7-8, 1903. 
342 THE JOURNAL OF AGRICULTURE OF THE UNIVERSITY OF P. R.

Report on observations in Porto Rico. U.S.D.A. Off. Expt. Sta. Ann. Rpt. $1903: 454$ 468, 1904. (Journ. N. Y. Bot. Gard. 4: 1904.)

Mycological Studies III. Bull. New York Bot. Gard. 3: 289-312, 1905.

Algunos hongos Cubanos. (Some Cuban fungi.) En Primer Informle Anual de la Estación Central Agronómica Cuba 1904-5: 225-246. 1906.

This paper is devoted to Agracineae.

La Diplodia natalensis. Rev. Agric. Com. Trab. (Cuba) 1:50, 1918.

Comments on a paper by Bruner and his own work.

Instrucciones para la eradicación de la enfermedad de la caña. (Instructions for the sugar-cane disease eradications.) Ins. Expt. Sta. Puerto Rico Cire. 14: 6-8, 1918.

Recommends the planting of healthy canes and roguing.

Informe leído ante la Asociación de Productores de Azúcar de Puerto Rico. (Report read before the Sugar Producers' Association of Puerto Rico.) Rev. Agric. Puerto Rico 2(1): 5-10, 1918.

Eradication as means of control in sugar-cane mosaic or yellow stripe. Ins. Expt. Sta. Puerto Rico Bull. 22, 17 p., 1919.

Gives the results of field studies on distribution and methods of control and also of experiments to determine methods of transmission.

The Year's experience with sugar-cane mosaic or yellow stripe disease. Journ. Dept. Agric. Puerto Rico 3(4) : 3-33, 1919.

Gives the results of field studies for control.

The resistance of cane varieties to the yellow stripe disease. Ins. Expt. Sta. Puerto Rico Bull. 19, 19 p., 1919.

Field studies to determine relative resistance and susceptibility.

The yellow stripe disease of sugar cane. Ins. Expt. Sta. Puerto Rico Ann. Rpt. 1918-19: 18, 1919.

Instrucciones para la eradicación de la enfermedad del mosaico de la caña. (Instructions for sugar-cane mosaic disease eradication.) Sugar 21:51-52, 1919.

A brief popular discussion. 
Carta Circular No. 4. (Circular Letter No. 4.) Rev. Agric. Puerto Rico 3(1):51-52, 1919.

The mosaic or new sugar-cane disease. Louisiana Plant. \& Sugar Manuf. 63: 167, 1919.

The author criticized Mr. R. M. Gray's article (Louisiana Plant. \& Sugar Manuf. 63:90) and declares that a stalk of cane once in. fested never recovers. Also states that Grey probably confused mosaic with other sugar-cane diseases.

Sugar-cane root disease. Journ. Dept. Agrie. Porto Rico 4(1): 3-27, 1920.

El mosaico de la caña o matizado. El estado actual de la epidemia. (Sugar cane mosaic or mottling disease. The actual stage of the epidemic.) Ins. Expt. Sta. Puerto Rico Circ. 22, 8 p., 1920.

Review of the work done in the Island to eradicate the disease.

La extirpación del mosaico. (Mosaie eradication.) Sugar 23: $114-115,1921$.

Importantísima carta. (Very important letter.) Rev. Agric. Com. \& Trab. Cuba 1(4):68-70, 1921.

Annual Report of the Expert in sugar-cane diseases, 1920-21. Ins. Expt. Sta. Puerto Rico Ann. Rpt. 1920-21: 59-62, 1921.

Experiences with mosaic disease. Uba found to be immune in Cuba. South African Sugar Journ. 7(5):427-428, 1923. (Rev. Appl. Mycol. 2: 525-526, 1923.)

Reports the spread of the disease and the immunity of some varieties.

Mosaic disease danger. Prompt action needed to stop its spread in Cuba. Facts About Sugar 16:230-231, 1923.

The disease is spreading rapidly in Cuba and very little is being done to control it.

Sugar-cane root diseases. A negleeted enemy of cane and ways of controlling it. Facts About Sugar. 16:314, 1923.

Popular.

Unknown cane disease found. Facts About Sugar. 16:383-385, 1923.

A description of spots on the leaves. 
344 THE JOURNAL OF AGRICULTURE OF THE UNIVERSITY OF P. R.

Sugar-cane root diseases. The greatest cause of loss to the cane growing industry-means of prevention. Facts About Sugar. $20(37): 882,1925$.

A statement of opinion.

Mosaic eradication urged. (Urge la extirpación del matizado.) Facts About Sugar 19(11): 253, 1923. (Rev. Agric. Puerto Rico 13(4) : 249-250. Australian Sugar Journ. 16(3):615$616,1925$.

Sugar-cane mosaic and sugar-cane chlorosis. Facts About Sugar. $19(16): 372,1924$.

A discussion of the characters of true mosaic and chlorosis.

Kavangerie in Porto Rico. (A reply to D. W. May.) Facts About Sugar 21 : 925-927, 1926.

Controversy.

Sugar cane and its culture. New York, 355 p.. 1928.

Discusses sugar cane diseases on pages 109-161; specially on the area covered by this work.

Sugar-cane varieties in Cuba. Planter and Sugar Manuf. 81 (19) : 361-362; (20) : 383-385; (21) : 404-405, 439; (22): $424-425$; (23) : 443-445, 459-460; (24) : 462-464; (25) : 482484, 1928.

Contains brief references to mosaic.

Immunity to sugar-cane mosaic acquired by the host. Proc. Nat. Acad. Sci. U.S.A. 17(6) : 331-334, 1931.

This paper is based on studies made in Cuba.

East. $\mathbb{E}[$ dward] $\mathbb{M}[$ [urray] \& Weston Jr., W[illiam] H[enry]

A report on the sugar mosaic situation in February, 1924, at Soledad, Cuba. Harvard Inst. Trop. Biol. \& Med., Contrib. 1, 52 p., 1925. (Rev. Appl. Mycol. 5(10): 582-583, 1926.)

A statement of the purpose of this journey and a discussion of the mosaic at Soledad, Cuba.

झllis, J[ob] B[icknell,] \& Everhart, B. IM.

Central American Pyrenomycetes. Iowa Univ. Bull. 2 : 395-415, 1893.

New species of fungi. Bull. Torrey Bot. Club 22:434-440, 1895.

\&

New species of tropical fungi. Iowa Univ. Bull. Lab. Nat. Hist. 4(1): 67-72, 1896. 


\section{\& Macbride, Thomas] H[uston]}

Nicaraguan Hymenomycetes. Iowa Univ. Bull. Lab. Nat. Hist. 3(4) : 190-194, 1896.

\section{Emmons, C[hester] W[ilson], \& Dodge, Bernard O[gilve]}

The ascocarpic stage of species of Scopulariopsis. Mycologia 23 (5) : 313-329, 1931.

\section{Emoto, $\mathbf{Y}$.}

Myxomyceten aus Mexico. (Myxomycetes from Mexico.) Bot. Mag. Japan 47:132-135, 1933.

\section{Ernst, Adolfo}

Candelilla ein Krankheit des Kaffeebaumes. ("Candelilla" a disease of the coffee tree.) Bot. Zeti. Regensburg, 34:3341, 1876.

Estudios sobre las deformaciones, enfermedades y enemigos del árbol de café en Venezuela. (Studies on the deformations, diseases and enemies of the coffee in Venezuela.) Bol. Cámara de Comercio de Caracas, 120, 31 p., 1877.

This paper won a prize in a contest and contains notes by Dr. H. Pittier. The author believes that coffee is not a suitable crop for Venezuela due to adverse climatic and soil conditions and especially external agents such as diseases, animal and plant parasites.

Estudios sobre las deformaciones, enfermedades y enemigos del árbol de café en Venezuela. (Studies on deformations, diseases and enemies of the coffee tree in Venezuela.) Caracas, 1878.

Coffee diseases in New Granada. Nature 23:292, 1880.

La epizootía de las moseas (Empusa muscae). (The epizooty of the flies.) La Opinión Nacional, Caracas, julio 15, 1880.

Hongos parásitos del árbol de café. (Parasitic fungi of the coffee tree.) La Opinión Nacional, Caracas, octubre 12, 1880.

Las familias más importantes del reino vegetal especialmente las que son de interés en la medicina, la agricultura e industria, o que están representadas en la flora de Venezulala. (The most important families of the vegetable kindom specially those of interest in medicine, agriculture and industry, or those represented in the Flora of Venezuela.) Caracas, 80 p., 1881.

Observaciones sobre la enfermedad de los pececillos. (Observations on the gold fish disease.) La Opinión Nacional, Caracas, diciembre 24, 1885. 
El tizón del maíz. (Corn smut.) Bol. Min. Obras Pub. Caracas, diciembre 26, 1891.

Hongos parásitos del árbol de café. (Parasitic fungi of the coffee tree.) Bol. Min. Obras Pub. Caracas, 1892.

Estudios nesológicos del cafeto. (Studies on coffee diseases.) Rev. Cafetera de Colombia 4(42-43) : 1553-1554, 1932.

Brief notes on the following topies: Coffee tree deformations, abnormal arrangement of lateral organs, leaf irregularity, abortion of one of the grains in the berry, pea berries and adherance of the fruit.

Espinosa Bustos, IMarcial $\mathbf{R}$.

Sobre las especies chilenas del género Fomes. (On the Chilean species of the genus Fomes.) Rev. Chilena Hist. Nat. 25 (1921) : 231-243, 1923.

Bibliography on page $342-343$.

Enumeración de hongos chilenos. (Enumeration of Chilean fungi.) Rev. Chilena Hist. Nat. 30:297, 1926.

Contribución al conocimiento de los hongos chilenos. (Contribution to the knowledge of the Chilean fungi.) Bul. Mus. Nac. Chile 9:65-94, 1916; 12:127-138, 1929.

\section{Essed, Ed.}

The Panama disease. Preliminary notice. Ann. Botany 24: 488-489, 1910.

Brief note. Believes that Panama disease is due to Ustilagineae.

The Panama disease I. Ann. Botany. 25(98):343-352, 1911. The author believes that the disease is caused by Ustilaginoidella musaeperda.

The Panama disease II. Ann. Bot. 25:353-361, 1911.

The author says-"I have convineingly proved that this disease, as it occurs in Suriname is caused by the Ustilaginoidella musaeperda.", He describes the organism.

The Surinam disease. A condition of Elephantiasis of the banana caused by Ustilaginoidelle oedipigera. Ann. Bot. 25: 363-365, 1911.

The author believes that the disease is due to Ustilaginoidella musaeperda. One symptom is "bigie toe" or Elephantiasis. 
Cacao canker. West Indian Bull. 12:302-308, 1912.

A description of the disease which is attributed to Spicaria colorans.

Evans, A. W.

Lichens and Bryophytes at Cinchona. Science 43:918, 1916.

Fairman, Charles E.

Notes on new species of fungi from various localities. Mycologia $5(4): 245-248,1913$.

Fantini, Nicolás

Ifa antracnosis y medios de curación. (Anthracnose and its cure.) Defensa Agric. (Uruguay) 1:179-180, 1920.

Popular discussion of antharenose caused by Gloeosporium ampelophagum.

\section{Faris, J[ames] A[braham]}

El mosaico de la caña de azúcar. Historia de esta enfermedad en la caña Dominicana. (Sugar-Cane mosaic. History of this disease in the Dominican Republic.) Rev. Agric. Santo Domingo $17: 73-76,90-95$, 105-108, 1922. (Rev. Appl. Mycol. $3: 437,1923$.)

A popular discussion of the disease and suggestions for the use of resistant varieties for control.

Cold chlorosis of sugar cane. Trop. Plant Res. Found., Sci. Con. No. 3. 1926 (Phytopathology 16(11): 885-891, 1926.) A deseription of this disease which is due to low temperature.

Some serious sugar-cane diseases not known to occur in Cuba. Trop. Plant Res. Found. Bull. 4, 22 p., 1926.

The author deseribes and discusses Sereh, Fiji, downy mildew, gummosis, leaf scald, dry top rot, smut, and cane rust.

Proc. 2nd. Int. Conf. Sugar-Cane Technologist, Havana, p. 99$100,1927$.

Field control of sugar-cane root disease conditions. Trop. Plant Res. Found. Bull. 6, 16, p., 1927.

A discussion of methods of improving the environment.

\& Allison R. 'V.

Sugar-eane root disease in Cuba: A progress report upon the root disease situation in 1925. Phytopathology 17(2):61$82,1927$.

A description of symptoms and the results of inoculation studies which were negative. The most important factor appears to be poor drainage. 
Zonate foot rot of sugar cane. Phytopathology 17(2) : 83-94, 1927.

Description of a disease which appears to be due to a Fomes.

Use of poor seed cane in Cuba. Facts About Sugar 22(35): 845, 1927.

Popular.

Some sugar-cane leaf spots in Cuba. Notes on observations of certain affections of eanes, including two believed to be new to science. Facts About Sugar 22(49): 1183-1184, 1927.

Popular.

Brown stripe of sugar cane in Cuba. Phytopathology (Abstract) $18(1): 135,1928$.

Attributes this disease to Helminthosporium stenospilum n. $\mathrm{sp}$.

Sugar-cane eye spot in Cuba Phytopathology (Abstract). 18(1) : 135, 1928.

Three Helminthosporium diseases of sugar cane. Phytopathology $18(9)$ : 753-774, 1928.

Says that H. sacchari is not the cause of the eye spot in Cuba but that the disease is caused by a new species H. ocellum. Also describes a new disease, the brown stripe which he attributes to a new species. H. stenospilum.

Informe sobre algunas enfermedades menores de la variedad de caña POJ-2878 en Cuba. (Some minor diseases of the POJ2878 cane variety in Cuba.) Memoria. Conferencia Ann. Assoc. Tec. Azucr. Cuba 3:92-105 (Spanish: 84-98), 1929.

A discussion of mosaic, nutritional chlorosis, stem galls and abnormal buds.

Field control of sugar-cane mosaic in Cuba. The Reference Book of the Sugar Industry of the World, 7:32-35, 1929.

A popular discussion with a great deal of yield data concerning Cuban conditions.

Some pathological effects of the mosaic disease of sugar cane. Planter \& Sugar Manuf. 82(21) : 404-405, 1929. 
El dominio del mosaico de la caña de azúcar en el campo Cubano.. (The range of mosaic of sugar cane in Cuban plantations.) Bol. Unión Panamericana 64(9) : 968-983, 1930.

The author gives three marked zones that occur in Cuba in regard to the spread of the disease. Gives the varieties best adapted to each zone and in each season.

The utilization of varieties in the field control of sugar-cane mosaic and root disease in Cuba. (A preliminary report.) Trop. Plant. Res. Found. Sci. Contr. 20, 69 p., 1931.

The author gives a large amount of data demonstrating that the use of resistant varieties is the most satisfactory method for the control of this disease.

\section{Fawcett G[eorge] L[orenzo]}

Report of the plant pathologist. Puerto Rico Agric. Expt. Sta. Ann. Rpt. 1908: 35-37, 1909.

Report of the Pathologist. Porto Rico Agric. Expt. Sta. Ann. Rpt. 1910: 35-36, 1911.

Report of the Pathologist. Puerto Rico Agric. Expt. Sta. Ann. Rpt. 1911:37-39, 1912.

Report of the Pathologist. Puerto Rico Agric. Expt. Sta. Ann. Rpt. 1912: 31-33, 1913.

Report of the Plant Pathologist. Puerto Rico Agric. Expt. Sta. Ann. Rpt. 1913: 26-29, 1914.

Eight Ann. Rpt. Proc. Cuban Nat. Hort. Soc., p. 21-30, 1914.

Pellicularia Koleroga on Coffee in Puerto Rico. Journ. Agric. Res. 2(3) : 231-233, 1914.

Discussion of a coffee leaf disease caused by the fungus Pellicularia Koleroga not described before from Puerto Rico. The author believes that this is a different disease from the one called "Candelilla" in Venezuela and attributed to the same fungus.

Apuntes botánicos y micológicos. Las enfermedades de las raíces de la caña. (Botanical and mycological notes. Cane root diseases.) Rev. Indus. Agric. (Tucumán) 6(1):37-38, 1915. Brief popular notes on Marasmins sacchari and nematodes.

A Puerto Rican disease of bananas. Puerto Rico Agrei. Expt. Sta. Ann. Rpt. 1915: 36-41, 1916. 
Enfermedad del cacao. (Cacao disease.) Rev. Indus. y Agric. (Tucumán) 10:52-54, 1920.

A disease reported from Ecuador and apparently due to Phytophthora faberi.

Notas preliminares sobre una enfermedad del tabaco. (A preliminary note on a tobaceo disease.) Rev. Indus. y Agric. (Tucumán). 12(1-2): 5-17, 1921.

The disease is caused by Bacillus sotanacearum.

La gomosis de los naranjos. (Gommosis of orange trees.) Rev. Indus. y Agric. (Tucumán) 12(11-12) : 149-155, 1922.

A semi-popular paper discussing two forms of the disease. The causes are Phytophthora terrestria. ( $P$. parasitica), Diplodia sp. and a Fusarium which is a form of Nectaria hematochronia.

Report of the Plant Pathologist. Puerto Rico Agric. Expt. Sta. Ann. Rpt. 1914:27-30, 1915.

Enfermedades del café causadas por hongos. (Fungous diseases of coffee in Puerto Rico.) Puerto Rico Agric. Expt. Sta. Bull. 17, 31 p., 1916.

General account of the most prevalent fungous diseases in Puerto Rico. Gives description of symptoms, and of the causal organisms and methods of control.

Una enfermedad de la caña producida por condiciones desfavorables de clima y suelo. (A sugar-cane disease caused by unfavorable climatic and soil conditions.) Rev. Indus. Agric. (Tucumán) 8(5-6) : 136-140, 1917.

The author refers to mosaic diseases and attributed it to unfavorable conditions of soil and climate.

La enfermedad de las rayas amarillas de la caña. (Yellow stripe disease of sugar cane.) Rev. Indus. Agric. Tucumán 10-46-48, 1919.

The disease is widely distributed on the Java varieties. Kavangerie is immune and D-1135 is resistant.

La verruga o "scab" de las citrus (Citrus scab), Rev. Indus. Agric. (Tucumán), 10(7-8) : 124-128, 1920.

Popular account describing the disease and giving methods of control.

Notas sobre la extirpación del mosaico de la caña. (Notes on sugar-cane mosaic eradication.) Rev. Indus. Agric. (Tucumán) $11(5-6): 74-76,1920$. 
The yellow stripe or mosaic disease in Argentina. Louisiana Planter \& Sugar Manuf. 64: 41, 1920.

Reports the disease as having been in Argentina for 15 years or more. It is abundant but not serious.

Enfermedades de la caña de Azúcar en (Tucumán). (Diseases of sugar-cane in Tucumán) Bol. Estac. Expt. Agri. (Tucumán) 13(1-2):1-46, 1922.

Describes a top rot or polvillo from which he isolated Bacillus flavidus n. sp. Mosaic is common. Reports Acrostalagmus glaucus n. sp. Cytospora sacchari, Melanconium sacchari, Fusarium sp. Acrostalagmus sacchari, Colletotrichum falcatum, Leptosphaeria sacchari, Phyllosticta sacchari, Marasmius sacchari.

Las enfermedades de la caña de azúcar en Tucumán. (Diseases of sugar-cane in (Tucumán) Estac. Expt. Agri. (Tucumán) Bol. 1, 47 p., 1924.

The author mentions dry bud rot, mosaic, sprout rot, yellow sprout, rind disease, common leaf spot, long leaf spot and root disease.

La transmisión del mosaico. (The transmission of mosaic.) Sugar 25:684, 1923. (Rev. Indus. Agric. (Tucumán) 13(7-8): 129-131, 1923. (Rev. Appl. Mycol. 3:367-368, 1924.)

A review of the work of Brandes and other on insect transmission.

La desinfección de la caña por la calefacción. (Sugar cane desinfection by heat.) Rev. Indus. Agric. (Tucumán) 13(1112) : 105-206, 1923 .

This paper gives the results of attempts to control mosaic by treatment with hot water. The results were negative.

El mosaico de la caña de azúcar. (The mosaic of sugar cane.) Rer. Indus. Agric. (Tucumán) 14(1-2):6-8, 1923. (Rev. Appl. Mycol. $3: 485,1924$.)

A popular discussion of the subject.

El mosaico o enfermedad de las rayas amarillas de la caña. (Mosaic or yellow stripe disease of the sugar cane.) Rev. Indus. Agrie. Tucumán 15(7-8): 103-111, 1925. (Rev. Agric. Com. \& Trab. Cuba 8(1):23-29, 1926.)

A popular discussion of the mosaic including information on vectors and method of control.

La desinfección de la caña. (Sugar-cane disinfection.) Sugar $27(1): 53,1925$.

A popular review of Dr. Wilbrink's hot-water treatment of cane. 
Departamento de Botánica y Patología Vegetal. (Department of Botany and Plant Pathology.) Rev. Indus. Agric. (Tucumán). 22(1-2) : 31-34, 1932.

Reports Cephalosporium sacchari on sugar cane.

Las rayas blancas de las hojas de la caña de azúcar. (The white stripes of sugar-cane leave.) Rev. Indus. Agric. (Tucumán) $22(11-12): 299-302,1932$.

May be due to low temperature.

Notas sobre las enfermedades de la caña de azúcar. (Notes on sugar-cane diseasess.) Rev. Indus. Agrilc. (Tucumán). 23 (3-4) : 68-69, 1933.

Departamento de Botánica y Pathología Vegetal. (Department of Botany and Plant Pathology.) Ex Memoria Anual del año 1932. (Annual Report for the year 1932.) Rev. Indus. Agric. (Tucumán) 23(11-12) : 243-247, 1933.

Some discussions of sugar-cane disease. Also mentions a disease of Citrus in Paraguay that resembles canker. (Pseudomonas citri.)

La fumagina de la caña de azúcar de Santa Fé y Corrientes. (Sooty mould of sugar cane in Santa Fé and Corrientes.) Rev. Indus. Agric. (Tucumán) 24(7-8) : 165-167, 1934.

Account of this minor sugar-cane fungus.

Clave para la determinación de las variedades de caña de azúcar cultivadas en Tucumán. (Key for the determination of the sugar cane varieties cultivated in Tucumán.) Tucumán (Argentine) Agric. Expt. Sta. Circ. 44:81-94, 1935.

This is a supplementary work to eircular 36 of the same series. In this work the reaction to mosaic disease is included as a character for the determination of the sugar-cane varieties.

Una nueva enfermedad del arroz en Tucumán: la brusone ( $P i$ ricularia Oryzea). A new rice disease in Tucumán: blast (Piricularia Oryzae) Tucumán (Argentine) Estac. Expt. Agric. Circ. 42, 6 p., 1935.

Account of the first report of rice blast caused by the fungus Piricularia Oryzae in Argentine. Control measures are suggested.

Notas sobre nuevas plagas del arroz en Tucumán. (Notes on new rice pests in Tucumán. Tucumán Ext. Expt. Agric. (Argentine) Circ. 45, 3 p., 1935.

Report of a new disease of rice (Entyloma Oryzae) and description of symptoms. 
Encrespamiento de las hojas de la remolacha azucarera. (Leaf curl of the sugar beet.) Rev. Indus. Agric. (Tucumán) 26. $(3-4)$ : 39-46, 1925.

Sugar beets of Argentine are attacked by a disease called "Encrespamiento" which is different from curly top. It is carried by a leaf-hopper, Aceratogallia sanguinolenta.

Departamento de botánica y patología vegetal. (Department of Botany and plant pathology.) Rev. Indus. Agric. (Tucumán) $19(9-10): 207-209,1927$.

Notes on curly top of sugar beets.

The curly top of sugar beet in Argentina. Phytopathology 17 (6) : 407-408, 1927.

Agallia stricticollis Stal. transmits the disease.

El encrespamiento de las hojas de la remolacha y el insecto trasmisor. (The curling of the leaves of the beet and the insect vector.) Rev. Indus. Agric. (Tucumán). 18(5-6) : 61-66, 1927.

Popular discussion.

La gomosis o pie podrido de los naranjos. (Gummosis or foot rot of oranges.) Rev. Indus. Agric. (Tucumán). 17:166-171, 1927.

A brief description of the disease with recommendations for its control. The author believes there is some causal agent other than Phytophthora parasitica.

Las manchas blancas de las hojas de la caña. (White spots of sugar-cane leaves.) Rev. Indus. Agric. (Tucumán): 17: 259-261, 1927.

A description of the disease.

El enrojecimiento de las hojas de algunas variedades de caña de azúcar. (The reddening of the leaves of certain sugarcane varietes.) Rev. Indus. Agric. (Tucumán). 19(34) : 104-105, 1928.

The disease is not considered important.

Apuntes sobre el mosaico de la caña de azúcar. (Notes on mosaic of sugar cane.) Rev. Indus. Agric. (Tucumán) 18(1112) : 205-209, 1928. (Rev. Appl. Mycol. 7:743, 1928.)

A discussion of varieties not eompletely immune to mosaic.

Departamento de Botánica y Patología Vegetal. (Department of Botany and Plant Pathology.) Rev. Indus. Agric. (Tucu- 
mán) 18(9-10):172-174, 1928. (Rev. Appl. Mycol. 7:562, 1928.)

Notes on different virus diseases of economic plants. Mosaic is the only important disease. Given the results of tests of P.O.J. 2725.

La clorosis de la caña recién brotada. (Chlorosis of recently sprouted cane.) Rev. Indus. Agric. (Tucumán) 19(7-8): 214-215, 1929.

El cultivo y las plagas del tabaco. (The cultivation and plagues of tobacco.) Rev. Indus. Agric. (Tucumán) 19(7-8) : 215216-1929.

A brief note.

Manera de determinar los lugares infestados por la enfermedad del ananás de caña de azúcar. (Mode of determining the field spots infested by the pineapple disease of sugar cane.) Rev. Indus. Agric. (Tucumán). 19(7-8) : 213-214, 1929.

Refers to Thielaviopsis paradoxa.

Plaga de los alfalfares. (Pest on alfalfa.) Rev. Indus. Agric. (Tucumán) 19(7-8): 215, 1929.

Notes on Rhizoctonia violacea on alfalfa.

El enruliamento, de las hojas de la tomatera. (Curly top of the tomato.) Rev. Indus. Agric. (Tucumán) 20(3-4):4954, 1930. (Rev. Appl. Mycol. 9:565, 1930.)

The author refers to this disease as curly top of the tomato in Argentine which is due to the same virus as the curly top of the sugar beet and is known in California as the western yellow blight of tomato. It is transmitted by Agallia stricticollis.

Las plantaciones de caña sin mosaico en Tucumán. (The cane plantations free from mosaic in Tucumán.) Rev. Indus. Agric. (Tucumán) $21: 126-127,1931$.

Report of the negative results obtained in Argentine by the roguing method for eradication of sugar-cane mosaic.

La pudrición negra de la caña de azúcar (Thielaviopsis). (The black-rot of sugar cane (Thielaviopsis) Rev. Indus. Agric. (Tucumán). 21(3-4) : 55-59, 1931.

La verrucosis de los “Citrus" Est. Exp. Agric. Tucumán. Circ. $26: 1-6,1931$.

Brief description and recommendations for the control of citrus scab. (Sphaceloma) 
Sobre algunas enfermedades del algodonero. (On some cotton diseases.) Est. Expt. Agron. Tucumán (Argentina) Cire. 52, 8 p., 1936.

Popular notes discussing angular leaf spot (Pseudomonas malvacearum E.F.S.) Circular spot (Cercospora gossypina Cke.); root diseases, mechanical injuries and diseases that may be introduced.

Fawcett, H[oward] S[amuel]

Citrus diseases of Florida and Cuba compared with those of California. California Agric. Expt. Sta. Bull. 262: 153-210, 1915.

\section{\& Lee, H[enry] Atherton.}

Citrus diseases and control. Me Graw-Hill Book Company, New York, 582. p., 1926. 2d. Ed. 1936.

A most thorough diseussion of all known diseases of eitrus.

\section{Fawcett, William}

Dr. Burck's method of treatment of the coffee-leaf disease in Java. Bull. Bot. Dept. Jamaica. 22:3-10, 1891.

Review of paper by Dr. Burck on the treatment of coffee against Hemileia vastatrix.

Includes populax notes on this fungus and gives warning to growers about this dreadful oriental disease of coffee. Includes government rullings.

Report on the coconut disease at Montego Bay. Bctanical Dept. Jamaica, Bull. 23, 2 p., 1891.

Report on the Cayman Islands. Botanical Dept. of Jamaica. $11: 3-4,1889$.

(Director of Public Gardens \& Plantations.) Report on Diseases in Sugar Cane. Society paper No. 27. (Proc. Agric. Soc. of Trinidad 1: 184-189, 1894.)

Popular. Mentions Colletotrichum falcatum, Trichosphaeria sac. chari, root fungus, rind disease and nematodes. The Bourbon cane was exterminated.

The prevention of the introduction and spread of fungoid and insect pesis in the West Indies. West Indian Bull. (Barbados) 1(1) : 108-113, 1899.

\section{\& Rendle, A. B.}

Citus.-Flora of Jamaica. 14(2) : 183-190, 1920.

Ferdinandsen, C[arl Christian Frederik], \& Winge, O[jvind] (Fungi from the Danish West Indies collected by C. Raunkiaër.) Bot. Tidsls $29: 1-25,1909$. 
(Fungi from Prof. Warming's expedition to Venezuela and the West Indies.) Bot. Tidrskrift 30:208-222, 1910.

Fernandes e Silva, $\boldsymbol{R}$.

A podridao preta e a podridao peduncular dos Citrus. (Black rot and stem end rot of Citrus.) Bol. Minist. Agric. Río de Janeiro 24(10-12) : 12-24, 1935.

The author reports black (Diplodia natalensis) and stem end rot (Phomopsis (Diaporthe) Citri) occurring in Brazil on citrus fruits. The author reviews the outstanding work on these diseases and their control by various well known American phytopathologist.

Fernández, D. S. \& Dijk, J. W. van

De intervimgsziekte bij de cacao. Bandbouco Proefst. Suriname, Meded 1, 47 p., 1926.

\section{Fernow, $\mathbf{K}[$ arl] $\mathbf{H}[$ ermann]}

Potato growing in Bermuda. Amer. Potato Journ. 8(6): 150153, 1931.

Leaf-roll potato plants give no yield in Bermuda.

Figueroa, C[arlos] A[rturo]

The mottling disease of cane and the sugar production of Puerto Rico. Journ. Dept. Agric. Puerto Rico. 3(4) : 35-43, 1919. A statistical study to determine the extent of the losses.

Filho; A. F. 0 .

O eambate contra o "mosaico" da canna d assucar. (The fight against the "mosaic" of sugar cane.) Brasil Agric. 12:65-70, 1927.

Fink, Bruce

The distribution of fungi in Puerto Rico. Mycologia 10(2): 58-61, 1918.

New species of lichens from Puerto Rico. I. Graphidaceae. Mycologia 19(4) : 206-221, 1927.

Ficher, Edward

Phalloideen aus Surinam. (Phaloides from Surinam.) Ann. Mycol. 25 : 470-473, 1927.

Untersuchungun über phalloidean aus Surinam. (Investigations on the phaloides of Surinam.) Naturf. Ges. Zürich 73:1-39, 1928.

Fischer, Gustavo J.

Observaciones sobre el rendimiento, la precocidad y la resistencia a la Puccinia triticina del trigo 38 M. A. (Observations 
on yield, precocity and resistence to Puccinia triticina of the wheat 38 M. A.). Nuestra Chacra 4(23):17-20, 1929.

As its title implies these are experimental observations on disease resistance breeding experiments.

\section{Fitzpatrick, Henry Morton}

Rostronitschkia, a new genus of Pyrenomycetes. Mycologia 11 (4) : 162-167, 1919.

Monograph of the Coryneliaceae. Mycologia 12(4):206-267, 1920.

Monograph of the Nitsehlieae. Mycologia 15(1):23-67, 1923.

The genus Fracehiaea. Mycologia 16(3):101-114, 1924.

A mycological survey of Puerto Rico and the Virgin Islands. Mycologia 19(3): 144-149, 1927.

A review.

The lower fungi. Phycomycetes. He Graw-Hill, New York, 331 p., 1930.

Fox, Alvin

Nut fall and leaf-drop of coconut-palms in Cuba. Cuba Rev. $17(1): 12-15,1918$.

Brief notes on Plytophthora.

Fredholm, A[dolf]

Fungi considered from an economic standpoint. Soc. paper 335 . Proc. Agric. Soc. of Trinidad. 8:393-400, 443-455, 1905.

Popular discussion ineluding a classification.

Maize or corn blight. Soc. paper 469. Proc. Agric. Soc. of Trinidad and 'Tobago. 11:354-355, 1911.

Popular diseussion of Ostilago maydis.

A possible inference to be drawn from the study on cacao canker. West Indian Bull. 12(3) : 308-310, 1912. (Trinidad \& Tobago Dept. Agric. Bull. 11 (70):46-48, 1912.)

Popular.

Diplodia disease of the coconut palm. Society Paper 367. Agric. Soc. of 'Trinidad \& Tobago 9(3): 159-172, 1909.

A very complete discussion of the disease. Caused by a Diplodia which may be same as the Botryodiplodia of Stockdate (See coconutpalm diseases in 'Trinidad) or with Diplodia epicocos Cooke. 


\section{Freeman, W[illiam] G[eorge]}

Sugar-cane mosaic. Trinidad \& Tobago. Administration Report of the Director of Agric. 1922, 12 pp., 1923.

Refers to a campaign for the eradication of mosaic.

Sugar-cane mosaic. Administration Report of the Director of Agriculture of the Dept. of Agric. Trinidad \& Tobago, 1921, 12 p., 1922. (Rev. Appl. Mycol. 2: 394, 1923.)

Refers to a campaign for the eradication of mosaic.

An algal disease of cacao. Trinidad \& Tobago Dept. Agric. Bull. 13(83) : 263-264, 1914.

Plant pests and diseases. Trinidad \& Tobago Dept. Agric. Report p., 31-33, 1925.

Witch broom in Trinidad. Trop. Agric. (Trinidad) 5(11): 287, 288, 1928.

A description of the disease which the author attributes to Marasmins perniciosus.

Lime cultivation. Diseases and pests. Soc. paper 610. Proc. Agric. Soc. of Trinidad. 15:12-13, 1915.

Popular abstract of an address.

\& Briton-Jones, H. R.

Witch-broom disease. A reply to criticisms. Trop. Agric. (Trinidad) 6(2):55-56, 1929.

Refers to Marasmius pernicious.

Freise, C. V.

Contribuicao as estudio histologico dos cafeeiros no Brazil (Cont.) D.N.C. Rev. (Río de Janeiro) 1935(2) : 829-831, 1935.

Fresa, R.

Argentine Republic: Melampsora larici-populina in the Delta of Paraná. Int. Bull. Plant Prot. 10(7) : 145-146, 1936.

Popular. Rust caused by the fungus Melampsora larici-populina is reported to have developed with great intensity on Populus nigra var. italica in the Delta of Paraná, this being the first record of its occurrence in the Argentine. Description of symptoms are given as well as associated organisms.

Freise, F[riedrich] W.

Cane diseases and plagues in Brazil. Mosaic, sereh, iliau diseases and gummosis are the most prevalent-low yield attributed largely to losses caused by these agents. Facts About Sugar $25(24): 613-614,1930$.

A popular diseussion of eane diseases in Brazil. 


\section{Fries, Robert Elias}

Myxomycetes von Argentinien und Bolivia. Arkiv. Bot. 1:5770, 1903.

Über einige Gasteromyceten aus Bolivia und Argentinien von Rob. Fries. Arkiv. Bot. 8(11) : 1-34, 1909.

Die Myxomyceten des Juan Fernández-Islen. In: Skottsberg, C. The Natural History of Juan Fernández and Eastern Island. V. II. Botany pt. 1., Uppsala, 1920.

Fries, Thore C.

Die Gasteromyceten des Juan Fernández-und Osterinseln. In Skottsberg, C. The Natural History of Juan Fernández and Eastern Islands. V. II. Botany Part 2, Uppsala, p. 59-60, 1922.

Forsyth, w. J.

King coffee, a new coffee-leaf disease developed in Soconnusco Chipas, México. New Iberia Exterprise, 21, 1896. (Trop. Agric. (Ceylon) 16:549-550, 1897.)

The author reports his observation in the coffee groves affected by the maladies.

Coffee planting in México; Coffee-leaf disease in Chiapas, México. Trop. Agric. (Ceylon) 16:629-631, 1897.

\section{Fortún Martínez, Gonzalo \& Bruner, Stephen C[ole.]}

Investigaciones sobre la enfermedad del mosaico o rayas amarillas de la caña de azúcạr. (Investigations on mosaic or yellow stripe disease of sugar cane.) Rev. Agric. Comm. \& Trab. Cuba 3:441-445, 1921.

The results of a field test with 52 varieties of cane to determine resistance and susceptibility.

El mosaic o rayas amarillas de la caña de azúcar. (The mosaic or yellow stripe of sugar cane.) Rev. Agric. Com. \& Trab. Cuba 6(1): 4-8, 1924.

¿Cuál es el origen del matizado en Cuba? (What is the origin of mottling in Cuba?) Rev. Azucarera (Argentina) No. 374: 1089, 1924.

\section{Furtado, C. X.}

Coconut tapering disease. Trop. Agric. (Ceylon) 61(2): 126, 1923.

A discussion.

\section{Gaillard, A.}

Le genere Meliola Paris, 163 p., 1892. 
Gándara, G.

Los nematodos del eafeto. (Coffee nematode.) Com. Par. Agric. (México) Circ. 51, 7 p., n. d.

Description of the nematode Heterodera radicicola and its effects on the coffee tree. He gives methods of control. Among the substances suggested to fight this pest he mentioned gasoline, benzine, copper sulfate, earbon bisulfate and potasium sulfocarbonate.

Enfermedades y plagas del naranjo. Est. Agric. Central, México, Bol. 111, 40 p., 1920.

Gandía Córdova, Ramón

La enfermedad de la caña. (The sugar cane disease.) Rev. Agric. Puerto Rico 3(1) : 63, 1919.

Popular account discussing the occurrence of the disease in Puerto Rico. He refers to sugar-cane mosaic.

Garanssini, .L. A.

El "pasmo" del lino Phlyctaena linicola Speg. Ensayo de campo de resistencia varietal y estudio morfológico y fisiológico del parásito. ("Pasmo" of flax. Phlyctaena linicola Speg. Field experiment on varietal resistance and a morphological and physiological study of the parasite.) Rev. Fac. Agron. (La Plata) 20(2):170-261, 1935.

Detailed account of experimental and field work of the disease. "Pasmo" of flax in Argentine caused by the fungus, Septoria linicola (Speg.) Nov. comb. (Phlyctaena linicola Speg.). A bibliography of 83 titles is appended.

Gardner, N [athaniel] L[yon]

New Myxophyceae from Porto Rico. Mem. New York Bot. Gard. $7: 1-144,1927$.

\section{Garman, Phillip}

Some parasitic Porto Rican fungi. Mycologia $7(6): 333-340$, 1915.

Gassner, G.

Die Getreideroste und ihr Auftreten im subtropischen östlichen Südamerika. Centralb. Bkt. Zweite Abt. 44:305-381, 1915.

Neue Feststellungen über Auftreten und Verbreitung der Getreiderostarten in Südamerika. (New facts concerning the occurrence and distribution of the cereal rusts species in South America.) Phytopath. Zeitschr. 4(2): 189-202, 1931.

Gives account of observation made by the author during a trip in South America in regard to the rusts found on cereals. 
Gaumann, r.

Mykologisehe Notizen II (Mycologieal notes II) Ann. Mycol. 34 (1-2) : 61-68, 1936.

Mention is made in these notes on the occurrence of Aecidium hippeastri $\mathrm{n}$. sp. on Hippeastrum bicolor leaves in Chile. Diagnose and description is given.

Giaccone, V.

Los principales enemigos del viñedo. (The principal enemies of the vineyard.) Defense Agric. (Uruguay) 1:67-70, 1920.

A popular report on the more important diseases including Oidium, Plasmopara, black-rot, chlorosis and a root rot.

Como curar el duraznero en primavera y principio de verano. (Treatment of the peach in Spring and early summer.) Defensa Agric. (Uruguay) 1:293-294, 1920.

Treatment for Txoascus deformans and Aphis persicae.

Gilber, Franls A[lbert]

Myxomycetes from British Guiana and Surinam. Mycologia 20.(1) : 27-28, 1928.

\section{Girardi, José}

Tumor bacteriano del duraznero. (Bacterial tumor of the peach.) Defensa Agric. (Uruguay):1:279-281, 1920.

A description of a gall which is said to be caused by Bacterium persicae.

La chlorosis de las plantas. (Chlorosis of plants.) Defensa Agric. (Ur'uguay) 1:300-302, 1920.

Gonodorma sessili Morrill. Argentina, Bol. Mins. Agric. de la Nación. 27(1) : 236-239, 1922.

The antlior gives description of this fungus and his observations on its behaviour and treatment.

Girola, C[arlos] D.

Enfermedades del tomate en Argentina: Podredumbre apical (Fusarium sp.), Antracnosis (Colletotrichum phomoides Sace.) Peronospora (Phytophthora infestans De Bary.) (Diseases of tomatoes in Argentine: Apical rot (Fusarinu sp.), Anthracnose (Colletotrichum phomoides Sace.) and Peronospora (Phytophthora infestans De Bary.) Bol. Min. Agric. Nac. Argentine 27:503-505, 1922.

\section{Goldi, Emil August}

Memoria sobre una enfermedad del cafeto en la Provincia de Río de Janeiro, Brasil. (Report on a disease of coffee in the Province of Río de Janeiro, Brazil.) Mexico, 118 p., 1894. 
Relatorio sobre a molestias do cafeéiro do Río de Janeiro. (Report of coffee diseases in the Province of Río de Janeiro.) Arch. Mus. Nac., Río de Janeiro 8:9-121, 1897.

Gómez IVIenor, J.

Las plagas en la agricultura dominicana. (The pests in the dominican agriculture.) Bol. Sec. Publ. Difus. Agric. Sec. Estado Agric. \& Com. Dominicana No. 12, 41 p., 1934.

Account of fungus diseases on p. 29-36.

Hongos que atacan el rosal. (Fungi that attack the rose.) Rev. Agric. Santo Domingo 27(78) : 2304-2303, 1936.

Popular notes are given on the rose diseases caused in the Dominican Republic by Actinema (Diplocarpon), Rosae and Pestalozzia discosioides. Control measures are suggested.

Hongos que ocasionan daños a las plantas "Flor de sol" (Fungi that damage sun-flower plants.) Rev. Agric. Santo Domingo $27(80): 2415,1936$.

Popular notes and control measures of three sunflowers diseases in the Dominican Republic.

Gonaux, C.B. et al.

Report of committee on Agricultural progress of the Louisiana Sugar Planters' Association for the year 1920. Louisiana Planter \& Sugar Manuf. 66: 185-189, 1921.

A report on the mosaic disease.

\section{Goncalves Carneiro, Joao}

A "mancha do olho pardo" da folha do Cafeeiro (The "brown spot" of coffee leaf.) Rev. Inst. Café. San Paulo (Brazil) $10(104): 1893-1895,1935$.

The brown spot of coffee (Cercospora coffeicola) is of little importance in Brazil. A description of the causal organism is given.

O tratamento des plantas citricas. (The treatment of citrus plants.) Rev. Citric. 7 p., 1935.

Popular direction for the treatment of the most common eitrus diseases in Brazil.

A pathologia do cafeeiro. (The coffee pathology.) Rev. Inst. Café. Est. (S. Paulo) Brazil. 10(105: 2131-2132, 1935.

Popular account about the importance of phytopathology in coffee culture of to-day.

Gonzales Fragoso, R[omualdo], \& Ciferri, $\mathbf{R}$ [afael]

Hongos parásitos y saprófitos de la República Dominicana. (Parasitic and saprophytic fungi of the Dominican Republic.) Bol. R. Soc. Esp. Hist. Nat. 25 (8) : 356-368, 1925. 
\&

Hongos parásitos y saprófitos de la República Dominicana. (Parasitic and saprophytic fungi of the Dominican Republic.) Bol. R. Soc. Esp. Hist. Nat. 25(9) : 443-456, (10) : 508-516, 1925.

$\&$

Hongos parásitos y saprófitos de la República Dominicana (9 Serie) (Parasitic and saprophytic fungi of the Dominican Republic (9th Serie). Bol. R. Soc. Exp. Hist. Nat. 27(2): 68-81, 1927.

\&

Hongos parásitos y saprófitos de la República Dominicana (11, $12,13,14,15$ Series) (Parasitic and saprophytic fungi of the Dominican Republic (Series 11-15) Estac. Agron. de Moca. (Santo Domingo) Ser. B. Botany. 11, 79 p., 1928.

\&

Hongos parásitos y saprófitos de la República Dominicana. (Serie 16) (Parasitic and saprophytic fungi of the Dominican: Republic (16 Serie) Bol. R. Soc. Esp. Hist. Nat. 28(7) : 377388, 1928.

\section{González Ríos, Policarpo}

El mal del plátano. Rev. Agr. Puerto Rico. 3(5) : 51-55, 1919. Popular account, very comprehensive.

Goodey, 'T.

On the nomenclature of the root-gall nematodes. J. Helm VII (4) : 223-230, 1932.

Gotoh, 'K.

On the black spot disease of the Dioscorea alata and D. batatas. (Gloeosporium pestis Massee.) Journ. Soc. Trop. Agric. 1: 301-319, 1929.

\section{Gough, Lewis Henry}

List of fungoid parasites of sugar cane observed in Trinidad. Dept. Agric. Trinidad \& Tobago Bull. 10(69) : 177-181, 1911. 1911.

A list of the diseases with brief bibliographies of each one.

Gowdey, C[arlton]

Relationship of insects to mosaic disease of sugar cane. Jamaica Dept. Agric. Ann. Rpt. 1924:19-20. (Rev. Appl. Ent. ser. A. $12: 442-445,1924$.

Graziana, A.

Deux champignos parasites des feuilles de coca. (Two parasitic fungi of coca leaves.) Bull. Soc. Mycol. France $7: 152-153$, 1891. 


\section{Gravier, Gabriel}

Conferencia pronuncaida por el Dr. Carlos E. Chardón, Comisionado de Agricultura de Puerto Rico en la Estación Agronómica sobre la enfermedad del mosaico o matizado de la caña de azúcar. (Conference delivered by Dr. Carlos E. Chardón, Commissioner of Agriculture of Puerto Rico in the Agricultural Experiment Station on mosaic or mottling disease of sugar cane.) Rev. Agric. Com. \& Trab. Cuba 7(8): 29-32, 1925.

\section{Guérin-Meneville, \& Porrottet}

Memoir sur un insects et un champignon qui ravagent les caféeirs aux Antilles. (Report on an insect and a fungus that attack the coffee tree in the Antilles.) Paris, Min. de la Marina, 32 p., 1842.

The authors describe and give biochemical data about a fungus which produces a disease on the coffee trees of the Antilles. The insect which they account for under the name Elachiste coffeella seems to be the first description of the well known coffee leaf miner.

Guilliermond, A.

A propos de l'origine des levurès. Ann. Mycol. 5:49-69, 1907.

Guiscafré, Arrillaga, J[aime R.]

Gomosis de la toronja en la Hacienda Eugenía (Puerto Rico)

(Grape-fruit gummosis in Hacienda Eugenia (Puerto Rico).

Rev. Obras Publ. 8(5): 124-125, 1931.

The brown rot fungus in Puerto Rico. Journ. Dept. Agric. Puerto Rico 16(2): 193-202, 1932.

Phytophthora (Pythiacytis) citrophthora.

The nature of inhibition between certain fungi parasitic on Citrus. Phytopathology 25(8) : 763-775, 1935.

The fungi under study were Diaporthe citri, Phytophthora parasitica and $P$. citrophthora on Citrus in Puerto Rico.

Guzmán, D. J.

Una enfermedad del cafeto en San Salvador (A coffee tree disease in San Salvador.) Com. Par. Agric. (Mexico) Circ. 60, 24 p., n. d.

Description of a coffee disease caused by the fungus Stilbella flavida. Account on its distribution and damages it causes. Bordeaux mixture is recommended as a control measure.

\section{Harkness, Harvey Wilson}

Fungi collected by T. S. Brandegee in Lower California in 1889.

Proc. California Acad. Sci. II, 2:231-232, 1889.

Hagelstein, $R$ [obert]

Mycetozoa from Porto Rico. Mycologia 19(1) : 35-37, 1927. 


\section{Hall, $\mathbf{C}$ [onatant] J[ohan] J[acob] van}

The witch-broom disease in Surinam. Trop. Life 2(6): 83, 1906.

\section{\& Drost, A. W.}

Les balais de sorciere du cacaoyer provoqués par Colletotrichum luxificum n. sp. (The witches-broom of cacao produced by Collectotrichum luxificum n. sp.) Recuil des Travaux Bot. Neederland, Vol. 4, p. 77, 1907.

\section{$\&$}

(The witch-broom disease in Suriname, its cause and treatment.) Suriname Dept. van Landb. Bull. 16, 1909. (Agric. Soc. Trinidad \& Tobago Soc. Paper No. 398, 1909.)

A very complete discussion of this disease which is caused by Exoascus theobromas.

Witches" broom disease of cacao. Journ. Bd. Agric. British Guiana. 2(3) : 126-132, 1909. (Rec. Trav. Bot. Neederland. 4(8) : 243-319, 1908. Roy. Bot. Gard. Kew Bull. Mise. Inf. 5: 223-224, 1909. Proc. Agric. Soc. Trinidad \& Tobago 9(12) : 475-564, 1909. Tropical Life $1: 12,1905$.

\section{$\&$}

De krulletonziekte der Cacaoboomen in Surinam, haar oorzaak en haar bestrijding. Surinam Dept. van Landb. Bull. 16, 17 p., 1909.

\section{Hall-de Jonge, A. E. van}

Kanka of Roodroot van den cacaoboom vervorzaakt door Spicaria colorans n. sp. Surinam Dept. van Landb. Bull. 20, 22 p., 1909.

De insterwingszielite der cacaoboom en hot "bruinrot" der cacaoviruchten, veroozaakt deer (Diplodia cacaicola). (The clie-back of cacao trees and the broom rot of cacao fruits.) Surinam Dept. van Landb. Bull. 21, 15 p., 1909.

\section{Hansford, C[lifford] G[erald]}

Sugar and mosaic disease of cane. Joun'n. Jamaica Agric. Soc. $27(8): 865-869,1923$.

History and deseription of the disease. Methods of transmission and control.

The mosaic disease of sugar cane. Jamaica Dept. Agric. Microb. Circ. 2, 14 p., 1923.

A very complete popular discussion of this disease.

Report of Microbiologist. Jamaica Dept. Agrie. Ann. Rept. 1922 : $24-26,1923$.

Results of work on Fusarium cubense. Also mentions mosaie of sugar cane, Colletotrichum falcatum, Marasmins sacchari, coconut bud 
366 THE JOURNAL OF AGRICULTURE OF THE UNIVERSITY OF P. R.

rot, Cercospora nicotianae, Cladosporium fulvum, Phomopsis sp. on mango, Guignardia bidwelli and Plasmopara viticola of grape, Colletotrichum agaves on sisal, Fusarium sp., Phytophthora sp., Thielaviopsis paradoxa and bacteria of pineapple. Also Aschersonia goldiana on Aleurocanthus woglumi.

The Panama disease of bananas. Jamaica Dept. of Agric. Microbiol. Circ. I, 28 p., 1923.

Tomato diseases and their control. Jamaica Dept. Agric. Microb. Circ. 3, 12 p., 1923.

Describes damping off in seed beds due to Rhizoctonia, Fusarium and Pythium. Also Cladosporium fulvum, Septoria lycopersici, Fusarium lycopersici, Bacterium solanacearum, Phytophthora infestans, Fusarium solani, Macrosporium solani and Colletotrichum phomoides.

Report of Government Microbiologist. Ann. Rept. Dept. Agric. Jamaica for the year ending 31st. December 1923:23-25, 1924.

Reports Fusarium cubense, Cercospora musarum, Sphaerostilbe musarum, Thielaviopsis paradoxa, Marasmius semiustus, Verticillum and Fusarium of the banana. Also Phytophthora palmivora of the coconut.

Mosaic disease of canes. Journ. Jamaica Agric. Soc. 27:961964, 1924.

The author discusses the spread of the disease, methods of eradication and the results of experimental work.

Forms of mosaic disease. Journ. Jamaica Agric. Soc. 29(1): 13-14, 1925.

A brief statement of different types of chlorotic diseases. A paper read by the author, discussing inspection, transmission and necessity for control.

Report of the Microbiologist.-Ann. Rept. Dept. Sci. \& Agric. Jamaica for year ending Dec. 1924:21-23, 1925.

Mentions Fusarium cubense, Cercospora musarum, Phytophthora infestans, Altenaria solani and Actinomyces scabies.

Some remarks on questions raised by the Panama disease of bananas. Proc. 9th. West Indian Agric. Conf. Jamaica. 1924: 41-51, 1925.

The disease is transmitted by suckers, by trash, by wind-borne spores and by soil. Discusses control and present position in Jamaica. 


\section{\& Sutherland, J. B.}

Panama disease of bananas. Journ. Jamaica Agric. Soc. 29(6) : 237-240, 1925.

Recommendation for the control of the disease.

Mosaic disease of sugar cane. West Indian Agric. Conf. Proc. $1924: 76-82,1925$.

This paper is devoted almost entirely to control and includes a discussion of transmission by Aphis maidis.

Panama disease of the Gros Michel banana. Proc. Agric. Soc. Trinidad \& Tobago 26(12) : 557-578, 1926.

A very complete popular discussion.

Report of the Microbiologist.-Ann. Rept. Dept. Sci. and Agric. Jamaica, ending Dec. 31, 1925:12-14, 1926.

Refers to several diseases of plants.

Panama disease in Jamaica. Jamaica Dept. Agric. Microb. Circ. 5, 35 p., 1926.

A summary of our knowledge of this disease.

The Fusaria of Jamaica. Kew Bull. Misc. Inform. 1926(7): 257-288, 1926.

Refers to Fusarium cubense, $F$. oxysporum, $F$. orthroceras, $F$. sclerotium and $F$. aurantiacum.

\section{\& Murray, P[ercival] W[aterhouse]}

The mosaic disease of sugar cane and its control in Jamaica. Jamaica Dept. Agric. Microb. Circ. 6, 39 p., 1926. (Int. Sugar Journ. 29(341) : 240-242, 1927. Rev. Appl. Ent. ser. A. 15: 96, 1927. Rev. Appl. Mycol. 6: 185, 1927.)

This is in reality two papers. The first by the senior author giving general discussion of symptoms, cause, transmission, hosts, effect on the cane and methods of control. The second by the junior author stating his experience in field control of the disease.

\section{Hanson, $\mathbf{A}[$ rthur] $\mathbf{P}$ [onton]}

Mosaic disease. Journ. Jamaica Agric. Soc. 28(7) :242-243, 1924.

The author discusses symptoms, effects and methods of control.

Hardy $\mathbf{F}$.

Studies on West Indian Soils. West Indian Bull. 19(2) : 189213, 1920.

Part of this paper is devoted to the relationship of soil to the die back disease of limes.

Hariot, 'Paul

Champignons: In Mission Scientifique du Cap. Horn, tome V, Botanique, Paris p. 173-200, 1889. 
Les maladies du baninier a la Jamaique. (The banana diseases in Jamaica.) Journ. Agric. Trop. 14:166-169, 1914.

Discussion of Panama disease, blackspot, Bonny-gate or Panama wilt, Marasmius rot, heart leaf disease and Surinam Panama disease.

Harland, S. C.

On the genetics of crinkled dwarf rogues in sea island cotton

Part II. West Indian Bull. 16(4) : 353-355, 1918.

The character of this paper is indicated by the title.

Manurial experiments with sea island cotton in St. Vincent in 1918-19, with some notes on the control of certain diseases by spraying. West Indian Bull. 18(1):20-32, 1920.

Contains a report on results of spraying.

Wither-tip disease of limes. Trop. Agric. (Trinidad) 3(4): 74-75, 1926.

A discussion of the efforts to control this disease which is caused by Gloeosporium limetticolum.

Hart, J. $\boldsymbol{H}$.

Cacao pod disease. Trinidad Bull. Bot. Dept. 3(11) : 167-168, 1889.

Some fungi of the cacao tree. West Indian Bull. 1(4):422427, 1900.

This paper contains historical data and discussion of Phytophthora omnivora De Bary and Nectria bainii Massee.

Cacao diseases. Trinidad, Bot. Dept. Bull. Misc. Inf. 27: 328. 1901.

Studies in cacao diseases. Proc. Agric. Bot. Trinidad \& Tobago 8(11) : 503-508, 1903.

Coconut disease. Roy. Bot. Gard. Bull. Misc. Inf. Trinidad 6: 241-243, 1905.

Bud rot disease in coconuts. Gulf Coast, 1905. (Preliminary Report.) Society paper No. 238, Proc. Agric. Soc. Trinidad. 6: 230-232, 1905. (Bull. Misc. Inf. p., 242-243, 1905.)

Popular. Writen before the cause of the disease was known. Refers to article on coconut fever in British Honduras, Jamaica and Demerara in Kew Bull. Vol., 1893: 41.

Studies in cacao diseases. Soc. Paper No. 343. Proc. Agric. Soc. Trinidad. 8:503-508, 1908. Popular. Mentions Diplodia cacaoicola. 
Diseases of cacao. West Indian Com. Circ. 24(289) : 509-513, (290) : 533-537, 1909.

The fauna of the cacao field. West Indian Com. Circ. 24(291): $557-561,1909$.

A note on one of the coconut diseases. Proc. Agric. Soc. Trinidlad \& Tobago 9(2): 60-61, 1909.

\section{Hauman-Merck, Luciano}

Les parasites végétaux des plantes eultivées en Argentine. (The vegetable parasites of cultivated plants in the Argentine.) Centralb. Bakt. Zweite Abt. 43:420-454, 1915.

Les parasites végétuax des plantes cultivées en Argentine et dans les régions limitrophes. (The vegetable parasites of plants in the Argentine and adjoining regions.) Ann. Mus. Nac. Buenos Aires 26: 163-225, 1915.

Notes floristiques, quelques cryptogames, gymnospermes et monocotylédones de l'Argentine. Ann. Mus. Nac. Hist. Nat. Buenos Aires 29: 391-443, 1917.

\section{\& Parodi, I. R.}

Los parásitos vegetales de las plantas en la República Argentina. (The vegetable parasites of plants in the Argentine Republic.) Rev. Facult. Agron. \& Veter. 3:227-274, 1921.

Hecq, L.

Una enfermedad del café en Perú. (A coffee disease in Perú.) Bol. Nin. Fomento (Perú) 4(9):30-39, 1906.

Popular account on a coffee leaf disease caused by the fungus Stilbella flavida. Bordeaux mixture and sanitation in the plantation are recommended as control measures.

Hedges, Florence

Sphaeropsis tumefaciens n. sp. The cause of the lime and orange knot. Phytopathology 1(2) : 63-65, 1911.

\section{\& Tenny, I. S.}

A knot of citrus trees caused by Sphaeropsis tumefaciens. U.S.D.A. Bur. Plant Ind. Bull. 274, 75 p., 1912.

Heller, A[mos] A[rthur]

Some Porto Rican fungi. Muhlenbergia 1(1):18-19, 1900.

Other Porto Rican fungi. Muhlenbergia 1(1): 19-21, 1901.

Molestias em cafezaes. (Coifee diseases.) Bol. Agric. Sec. 
370 THE JOURNAL OF AGRICULTURE OF THE UNIVERSITY OF P. $R$.

Agric. Com. \& Obras Publ. (S. Paulo) Brasil 22(11-12): 330-332, 1921.

Brief notes on coffee diseases observed by the author in the coffee groves of Piratininga, Brazil.

(A new species of fungus-producing canker on cacao trees.) Bol. Agric. Sec. Agric. Com. \& Obras Publ. S. Paulo, Brazil $5(1): 22-24,1904$.

Ceroccocus paraphybensis n. sp. Nota preliminar. Rev. Mus. Paul., S. Paulo 15 : 389-391, 1927.

\section{Hennings, $\mathbf{P}$.}

Fungi brasilenses II. Reprinted from Engler Bot. Jahrb. 17 : 523-526, 1893.

Neue und interessante Pilze aus dem Königh botanischen museum in Berlin II. Hedwigia 33: 229-233. 1894

Fungi Goyazenses. Hedwigia 34:88-112, 1895. (Bull. Torr. Bot. Club 22: 478-484, 1895.)

Fungi Blumenaviense. Hedwigia 34: 335-338, 1895.

Naträge zu den Fungi Goyazenses Hedwigia 34:419-324, 1895. (Bull. Torr. Bot. Club 22 : 113-116, 1896.)

Nachträge zur Plizflora Sudamerika II. Hedwigia 36:190-192, 193-246, 1897.

Die Gattung Diplotheca Starb. sowie einige interesante und neue, E. Ule gesammelte Pilze aus Brasilien. Beiblatt zur Hedwigia $37: 205-206,1898$.

Fungi jamaicensis. Hedwigia 37:281, 1898.

Xylariodiseus nov. gen. und einige neue brazilianische Ascomysetes des E. Ule schen herbars. Hedwigia, Beiblot 38: $63-65,1899$.

Fungi chilensis a cl. Dr. F. Neger collecti. Hedwigia, Beiblat. 38: 129-130, 1899.

Fungi paráenses-I. Hedwigia, Beiblat. 39:76-80, 1900.

Fungi mattogrossenses a Dr. R. Pilger collecti 1899. Hedwigia, Beiblat 39:134-139, 1900. 
Einige neue Uredineen aus verschiedenen Gebieten. Hedwigia $39: 153-155,1900$.

Taxonomic: records Puccinia Porophylli as new species from Venezuela.

Fungi paráenses. Bull. Mus. Paráenses 3: 231-237, 1901.

Fungi costaricenses I. a cl. Dr. H. Pittier. Hedwigia, Beiblat 41: 101-105, 1902.

Fungi Blumenavienses II. A Cl. Alfr. Möller lecti.- Hedwigia $41: 1-33,1902$.

Fungi paráenses II Cl. Dr. J. Huber collecti Hedwigia, Beiblat 41: 13-18, 1902. (Mus. Goeldi 4: 407-414, 1904.)

Fungi fluminensis a Cl. E. Ule collecti. Hedwigia 43:78-95, 1904.

Einige neue pilze aus Costarica und Paraguay. Hedwigia 43 : 147-149, 1904.

Fungi amazonici a Cl. Ernesto Ule collecti. Hedwigia 43: 154 186, 242-273, 351-352, 353-400, 1904; 44: 57-71, 1906.

Fungi bahiensis. Hedwigia 47:266-270, 1908.

Fungi S. Paulenses I-IV a Cl. Puttemans collecti. Hedwigia 41 : 104-118, 295-311, 1902; 43: 197-208, 1904; 48: 1-20, 1908.

Fungi paráenses I. Hedwigia, Beiblat 48: 101-117, 1908.

Aliquot fungi peruviani novi. Bot. Jahrb. Engler 40:225-227, 1908.

Henricksen, H[enrick] C[hristian]

Vegetable growing in Puerto Rico. Puerto Rico Agric. Expt. Sta. Bull. 7, 58 p., 1906.

Popular. Mentions several diseases of common occurrence in Puerto Rico.

Herculais, J. K. d'

Los hongos parásitos de las langostas, su propagación natural y artificial. (The parasitic fungi of the locust, its natural and artificial propagation.) Buenos Aires 38 p., 1920.

Hernández Torres, Oscar

Control del "mosaico" o "rayas amarillas" de la caña de azúcar (Control of "mosaic" or "yellow stripe" disease of sugar cane.) Rev. Agric. Com. \& Trab. Cuba 10(4) : 16, 1928. 


\section{Herre, Albert [William], C[hristian Theodore]}

Notes on Mexican lichens. Bryologist 23:3-4, 1920.

Herrera, A. L.

Las plagas de la agricultura. (The agricultural pests.) México Min. de Fomento, Parts 3-7:179-434, 1903.

Popular account of crop pests in Mexico.

Algunas enfermedades del cafeto. (Some coffee tree diseases.) Com. Par. Agric. (México) Circ. 1, 8 p., n. d.

Brief discussion on the diseases caused by Stilbum flavidum and Sphaerella coffeicola. Bordeaux mixture is recommended as a contrōl measure.

Resultados prácticos al combatir las plagas agrícolas. (Practical results in combating agricultural pests.), Com. Par. Agric. (México) Cire. 11, 49 p., n. d.

Popular notes on practical results obtained with fungicide used on agricultural crops in Mexico.

La enfermedad del cafeto en Oaxaca. (The coffee tree disease in Oaxaca.) Bol. Com. Par. Agric. (México) 2(5):207-276, 1904.

Summary of reports on the disease caused by the fungus Stilbella flavida. Other organisms are considered in this report. Bordeaux mixture is given as a remedy for most leaf troubles of coffee of fungus origin.

\section{Hesler, L[exemuel] $\mathbf{R}$ [ay]}

Progress report on citrus scab. Puerto Rico Agric. Expt. Sta. Report. $1917: 30-31,1918$.

A preliminary report. Disease is caused by Cladosporium citri. Recommendations for control.

Hewison, H. K., \& Symond, J. E.

Mycological notes. Trop. Agric. (Trinidad) 5(4) : 93, 1928.

A brief reference to Alternaria longipedicillata on cotton.

Hicken, C. IM.

Segunda contribución al conocimiento de la bibliografía botánica Argentina. (Second contribution to the knowledge of the botanical bibliography of Argentine.): Darwiniana 1: 319-430, 1929.

\section{Hill, A. W.}

A visit to the West Indies. Kew Bull. Mise. Inf. p. 166-189, 1912.

Hill, R. G. \& Hawkins, Lon A.

Transportation of citrus fruits from Puerto Rico. U.S.D.A. Bull. 1290, 19 p., 1924.

A paper on refrigeration. The one fungus mentioned is Diplodia natalensis. 
Hirschhorn, Elisa, \& Hirschhorn, J.

Los carbones del maíz en la Argentina. Caracteres sistemáticos, genéticos y parasitorios. Observaciones preliminares. (Maize smuts in the Argentine. Systematic, genetic and parasitic characters. Preliminary observations.) Rev. Fac. Agron. La Plata 20 (2) : 108-139, 1935.

Corn smuts in the Argentine Republic has hitherto attributed extensity to Ustilago Zeae and $U$. abortifera described by Spegazzini in 1881, but the authors made extensive studies on the systematic position, biology and pathogenicity of diseased material from all over the country as well as from Venezuela and Paraguay. The results of their studies are given in detail.

Hirschhorn, J.

Dos royas de la cebada, nuevas para la Argentina. (Two barley rusts new to the Argentine.) Rev. Fac. Agron. Univ. Nac. La Plata 19(3) : 390-397, 1933.

This is a continuation of work published in 1930 reporting on that date the appearance of these two rusts on barley in the Argentine Republic. (Puccinia anomala and P. glumarum.) After describing the life-history and symptoms of the former it is stated that judging by the character of the infection on different species (Hordeum spontaneum and $H$. deficiens.) and several other varieties the biotype of $P$. anomala occurring in Argentine is distinct from those found in Australia and United States. $P$. glumarum has been found to occur in a much more virulent form on $H$. spontaneum and its var. nigrum, H. tetrastichum, and H. hexastichum than on H. distichum. In 1931 H. pusillum Nutt. var. enclaston Steud (H. enclaston Steud.) was attacked by yellow rust.

Dos royas de la cebada nuevas para el país. (Two barley rusts new to the country.) Physis, Rev. Soc. Argentina Cienc. Nat. $11(38)$ : 166-167, 1933.

Records the oceurrence of Puccinia anomala on Hordeum distichun and $P$. glumarum on $H$. tetrastichun, $H$. hexastichun, H. spontaneum, H. spontaneum var. nigrum.

\section{Hitchcock, A[lbert] S[pear]}

Cryptogams collected in the Bahamas, etc. Missouri Bot. Gard. Rpt. 9: 111-120, 1898.

\section{Hohnel, Franz von}

Eumycetes et Myxomycetes. In Wettstein, R. and Schiffner. V. Ergebaisee der botanischen expedition der Akademie der wissenschaften nach Südbrasilien 1901. v. 2 Deutschr. MatuNatur. Kl. Akad. Wiss. Wnero 83:1-45, 1927.

\section{Holway, E[dward] W[illet] D[orland]}

Mexican fungi. Bot. Gaz. 24(1): 23-38, 1897.

Mexican fungi. Bot. Gat. 24( ) :23-28, 1897; 28( ):273274,$1899 ; 31(\quad): 326-338,1901$. 
Mexican Uredineae. Ann. Mycol. 2( ) : 291-294, 1904.

Hooker, W. C.

(In Kunth, C. S.) Synopsis plantarum quas in plagam aequinoctialem Orbis Novi collegerunt Al. de Humboldt et Am. Bonpland p. 7-15, 1822.

Hopkins, J. C.

Notes on the soft rot of cotton bolls in the West Indies caused by Phytophthora. Ann. Bot. 39(154):267-280, 1925.

Report of three strains of Phytophthora on cotton bolls. One from Montserrat resembled $P$. parasitica; one from St. Vincent indistinguishable from $P$. palmivora and one from Trinidad resembling $P$. parasitica.

Horne, Mary Tracy [Earle]

The coconut industry in Cuba. Cuba Rev. 5(11):18-20, 1907. Popular.

\section{Horne, W[illiam] T[itus]}

The bud rot and some other coconut troubles in Cuba. (English \& Spanish Ed.) Est. Central Agron. Cuba Bull. 15, 43 p., 1908.

$$
\text { Popular. }
$$

Phomopsis in grapefruit from the Isle of Pines, W. I., with notes on Diplodia natalenses. Phytopathology 12(9): 414-418, 1922.

\section{Hotson, J. W., \& Hartge, Lena}

A disease of tomato eaused by Phytophthora mexicana. n. sp. Phytopathology 13(12) : 520-530, 1923.

This organism was isolated from tomatoes shipped from Mexico to Washington.

\section{Howard, Albert}

On Trichosphaeria sacchari Massee. Ann. Bot. 14: 617-631, 1900.

Diplodia cacaoicola a parasitic fungus on sugar cane and cacao in the West Indies. Ann. Bot. 15(60):683-701, 1901.

The fungus diseases of cacao in the West Indies. West Indian Bull. 2(3) : 190-211, 289, 1901.

This paper contains a discussion of the brown rot disease of the pod (Diplodia cacaoicola P. Henn.), the Trinidad cacao pod disease (Phytophthora omnivora de Bary), Nectria bainii Massee; a canker disease (Nectria ditissima Tul.) of the stem which also attacks Erythrina umbrosa, the witch-broom disease of Surinam (Exoascus theobromae Ritz. Bos.) and root disease. 
Witch-broom of cacao. West Indian Bull. 2(2) : 205-206, 289 $290,1901$.

Popular notes.

The field treatment of cane cuttings in reference to fungoid diseases. West. Indian Bull. 3(1):73-86, 1902.

This paper gives the results of efforts to control Thiclaviopsis by treatments with Bordeaux mixture, tar, lime, water, etc.

Suggestions for the removal of epiphytes from cacao and lime trees. West Indian Bull. 3(2): 189-197, 1902.

These organisms, mostly Cuscuta and Loranthaceae are injurious.

On some diseases of sugar cane in the West Indies. Ann. Bot. $17: 373-412,1903$.

The rind disease of sugar cane in the West Indies. Intern. Sugar Journ. 5(53) : 215-225, 1903.

A very comprehensive description of this trouble due to Melanconium.

Howe Jr., R[eginald] Heber

On a small collection of lichens from Jamaica, West Indies. Mycologia 6(5) : 259-263, 1914.

The Usneas of the World, 1752-1914, with eitations types localities, original descriptions and keys. Part II, South America. Bryologist 18: 38-43, 52-63, 1915.

An interesting tropical lichen new to the United States. Torreya $16: 50,1916$.

Huergo Jr., José MT. de

Antracnosis de la vid. (Vine anthraenose.) Buenos Aires 28 p., 1899.

Enfermedad radicular de la vid causada por la Heterodera radicicola o Anguilula radicicola de Greef (Anguilulosis) (Root disease of the vine caused by Heterodera radicicola or Anguilula radicicola Greef.) Bol. Min. Agric. Buenos Aires 5(1): 29-56, 1906.

Enfermedad radicular del tomate. (Root disease of the tomato.) Bol. Agric. \& Ganadería, Rep. Argentina, 2(42) : 1040-1059, 1902.

\section{Humphrey, Harry Baker \& Cromwell, Richard O[liver]}

Stripe rust, Puccinia glumarum, on wheat in Argentine. Phytopathology 20(12) : 981-986, 1930.

Description of the symptoms of the disease and its behavior. 


\section{Humboldt, Alexandri de, Bonpland, Aamati, \& Kunth, Carol Segismund.}

Nova genera et Species Plantarum quas in peregrinaciones ad plagam aequinoctialem Orbis Novi collegerunt, descripserunt, partim adumbraverunt Amat. Bonpland et Alex. Humboldt, exchedis autographis Amati Bonpland in ordinem digessit Carol Segismund Kunth accedunt tabulae acri incisae, et Alexandri de Humboldt natationes ad geographiam plantarum spectantes. Lutecia Parisorum VII, 1895.

Hunneus, $\mathbb{R}$.

Enfermedad del cacao. (Cacao disease.) Bol. Assoc. Agron. Ecuador 1(2) : 19-22, 1920.

\section{Hunt, Willis $\mathbf{R}$ [oberts]}

Miscellaneous collections of North American rusts. Mycologia $19(5): 286-288,1927$.

Records Uromyces Fabae (Pers.) De Bary on Vicia Faba L., Coleosporium Solidaginis (Schw.) Thüm on Solidago sempervirens L., Gymnosporagium bermudianum (Farl.) Earle on Juniperum bermudiana L., Puccinia Hieracii (Schum.) Mart. on Cichorium Intybus L., P. Lantanae Earl. on Lantana involucrata L., and U. Medicagines Pass. on Medicago lupulina L. all from Bermuda.

Ihering, $\boldsymbol{H}$.

Der brasilianische Korceebau und seine Schadlinge. Mittil. uber Brasilien, Berlin 661-670, 1925.

Illingworth, J. Lawson

Notes on gumming disease of isugar cane. Leeward Islands Dept. Agric. 12 p., 1930.

The author gives a brief discussion of the symptoms, effects of the disease, the causal organism, dissemination and varietal susceptibility.

Infante, Jorge $\mathrm{s}$.

Nociones sobre enfermedades del cafeto. (Notions on coffee tree diseases.) Rev. Cafetera de Colombia 4(36-37): 1351-1353, 1932.

Brief notes on coffee diseases specially those of fungus origin. Special attention is given to those caused by Hemileia vastatrix and Corticium Koleroga.

Iriarte, David $\mathbf{R}$.

Observaciones sobre el carate en el Distrito Perijá del Estado Zulia. (Observations on "carate", in the District of Perijá, State of Zulia.) Gaceta Muskus, Caracas 3(34): 16-18, 1932.

Carate: A disease of the skin-dark spots.

\section{Jackson, $\mathbf{H}$ [erbert] $\mathbf{S}$ [pencer]}

New or noteworthy rusts on Carduaceae. Mycologia 14(3) : 104120, 1922. 
The rusts of South America based on the Holway Collection I. Mycologia 18(4) : 139-162, 1926.

The rusts of South America based on the Holway Collections II. Mycologia 19(2) : 51-65, 1927.

The rust of South America based on Holway Collection III. Mycologia 23(2) : 96-116, 1931.

The rusts of South America based on the Holway Collections IV. Mycologia 23(5) : 332-364, 1931.

The rusts of South America based on Holway Collection V. Mycologia 23(6) : 463-503, 1931.

The rusts of South America based on Holway Collection VI. Mycologia 24(1): 62-186, 1932.

Jackson, T. P.

Work connected with insect and fungus pests and their control.

St. Vincent Dept. of Agric. Ann. Rpt. 1928: 8-14, 1929.

Work connected with insect and fungus pests and their control. St. Vincent Dept. of Agric. Ann. Rpt. 1931: 7-13, 1932.

Jacquet, J. $\mathbf{H}$.

Les balais de sorciere du cacaoyer et les moyens de les eviter.

(Witches' broom of cacao and the means of avoiding it.) Agron. Colon (Ecuador) 18(137) : 129-133, 1929.

Refers to Marasmins perniciosus.

John, Eward

Myxomyceten aus Amazonas gesammelt E. Ule. Hedwigia 43: 300-305, 1904.

Jamieson, Clara C.

Phoma Destructiva the cause of a fruit rot of the tomato. Journ. Agric. Res. 4(1) : 1-20, 1915.

Occurrence and general appearance of the disease.

Jaynes, H. A.

Pineapple disease, (Thielaviopsis ethaceticus) on sugar cane at Tucumán, Argentina. Phytopathology 22(7) : 667-668, 1932.

\section{Jehle, $\mathbb{R}$ [obert] A[ndrew]}

El tizón tardío y la pudrición de la papa. (Late blight and potato rot.) Cuba Est. Expt. Agron. Circ. 48, 6 p., 1915. 


\section{Jenkins, Anna E[liza]}

A scab disease of lima bean in Cuba and Puerto Rico. U.S.D.A. Plant Disease Reporter. 14(11): 96-97, 1930.

This disease of Phaseolus lunatus is caused by Elsinoe canavaliae. The author published a very complete discussion of this fungus and the disease in Journ. Agric. Res. 42(1): 13-23, 1931.

Lima bean scab caused by Elsinoe. Journ. Agric. Res. 42(1) :1323, 1931.

Further studies of lima-bean scab. Phytopathology 23(8) : 662666, 1933.

This disease is due to Elsinoe canavaliae. The range has been extended to Costa Rica, Nicaragua, Guatemala, El Salvador, Dominican Republic and possibly to Jamaica.

A Sphaceloma attacking naval orange from Brazil. Phytopathology 23(6) : 538-545, 1933.

A species of Sphaceloma on avocado. Phytopathology 24(1): $84-85,1934$.

New species.-Sphaceloma perseae.

\section{Jensen, J[ames] $\mathrm{H}$.}

Notes on the present Sugar-cane diseases situation in Puerto Rico. Agric. Notes, Puerto Rico Agric. Expt. Sta. (Mayagüez) 69, 8 p., 1936.

Brief popular notes on the occurrence of the most common disease of sugar cane in Puerto Rico.

Notas sobre la presente situación de las enfermedades de la caña de azúcar en Puerto Rico. Rev. Agric. Puerto Rico. 18(1): 89-94. 1936.

Popular.

Chlorosis of Citrus in Puerto Rico Phytopathology, 27(6) : 731. 1937.

Treatment with zinc sulphate.

Jiménez Núñez, E.

El cultivo de la caña de azúcar. (Sugar-Cane Cultivation.) Centro Nal. de Agric. (Argentina) Bull. 6:3-24, 1930.

Jobert, C.

Sur une maladie du cafeier observée au Brasil. Compt. Rend. Hebdomadáires des Séances de l' Académie d' Agri., France 87: 941-943, 1878. 
Joglar Rodríguez, F' [rancisco]

"El mosaico" enfermedad del tabaco. Rev. Agric. Puerto Rico. 25(10): 150, 176, 1930.

Popular diseussion and description.

\section{Johann, EIelen}

Diplodia macrospora on corn in Brazil. U.S.D.A., Plant Disease Rep. 19(1):9-10, 1935 .

A record of this disease on corn from Brazil where it is considered new. This fungus was deseribed by Farle and has been reported from Alabama, North Carolina, South Carolina, Florida and Louisiana.

\section{Johansson, $N$.}

A contribution to the knowledge of the etiology of fruitlet black rot disease of pineapple. Svensk. Bot. Tidskr., 28(3) : 384404,1934 .

An account of this disease in Guatemala. The author aceepts the work of Barker in Faiti and Serrano in the Philippine that the disease is caused by Bacillus ananas.

\section{Johnston, John R[obert]}

The bud-rot of the coconut palm. U. S. Bur. Plant Indus. Circ. 36,5 p., 1909.

A brief history of the disease without statement as to cause.

The serious coconut palm diseases in Trinidad. Dept. Agric. Trinidad, Bull. 9(64):25-29, 1910.

A popular discussion.

The history and cause of coconut but-rot. U. S. Plant Indus. Bull. 228, 175 p., 1912.

These studies were made on material from Cuba and the author attributed the disease to Bacillus coli (Escherich) Migula. Later studies of what appear to be the same disease in Puerto Rico indicated that it is due to Phytophthora palmivora.

The present status of the coconut bud rot disease. 1910. (Published in Cuba.)

A brief history of the disease and its geographical distribution. No statement as to cause.

Is Bacillus coli ever a plant parasite. Phytopathology 1:97$99,1911$.

First report of the pathologist. Puerto Rico Agric. Expt. Sta. Sugar Prod. Ass'n. Bull. 1: 35-48, 1911.

Report of the pathologist. Puerto Rico Sugar Prod. Assoc. Agric. Expt. Sta. Second Ann. Rpt. 1911-12 (Bulletin 2) :232S, 1912. 
Cultivation of the coconut in Puerto Rico. Puerto Rico Hort. Soc. First Rpt. 1912: 47-55, 1912.

The relation of cane cultivation to the control of fungous diseases. Puerto Rico Agric. Expt. Sta. Sugar Prod. Assoc. Circ. 3, 13 p., 1913.

Selection and treatment of cane seed. Puerto Rico. Agric. Expt. Sta. Sugar Prod. Assoc. Bull. 6, 29 p., 1913.

Notes on the fungous diseases of sugar cane in Puerto Rico. Phytopathology (Abstract) 3: 75, 1913.

Third report of the pathologist. Puerto Rico Sugar Prod. Assoc. Agric. Expt. Sta. Bull. 5: 22-24, 1913.

The nature of fungous diseases of Plants. Puerto Rico Sugar Prod. Ass'n. Circ. 2, 25 p., 1913.

La enfermedad del plátano en Cuba. (The plantain disease in Cuba.) Cuba Estac. Expt. Agron. Circ. 47, 13 p., 1915.

Causa de la enfermedad llamada pudrición del cogollo del cocotero. (Cause of the so called coconut palm bud rot.) Cuba Estac. Expt. Agron. Bull. 27, 106 p., 1915.

Entomogenous fungi of Puerto Rico. Ins. Expt. Sta. Puerto Rico. Bull. 10, 33 p., 1915.

Phytopathological work in the tropies. Phytopathology 6:383, 1916.

The banana diseases and its control. Bull. Comm. San. Veg. Cuba, 1: 80-81, 1917.

Popular.

History and cause of the rind disease of sugar cane. Journ. Comm. Agric. Puerto Rico 1(1):17-45, 1917.

Notas sobre micología y patología vegetal en Cuba. (Notes on mycology and plant pathology in Cuba.) Mem. Soc. Cubana Hist. Nat. 2 : 225-228, 1917.

\section{\& Stevenson, John A[lbert]}

Fungi and diseases of sugar cane in Puerto Rico. Journ. Dept. Agric. Puerto Rico 1(4) : 228-233, 1917.

Brief notes: Early account of the occurrence of mosaic disease of sugar cane (called mottling) in Puerto Rico. 
$\&$

Sugar-cane fungi and diseases of Puerto Rico. Journ. Dept. Agric. Puerto Rico 1(4) : 177-264, 1917.

El plátano y sus enfermedades. (Banana and its disease.) Rev. Agric. Com. \& Trab. Cuba, 1:419-421, 1918.

\section{\& Bruner, Stephen C[ole]}

A Phyllachora of the Royal Palm. Mycología 10(1):43-45, 1918.

Enfermedades y plagas del cacao en el Ecuador y métodos modernos apropiados al cultivo del cacao. (Cacao diseases in Equador and methods of cacao cultivation.) Phytopathology $8(10): 550,1918$.

Review of paper of same title by J. B. Rorer.

Algunos hongos entomógenos de Cuba. (Some entomogenous fungi from Cuba.) Mem. Soc. Cubana Hist. Nat. "Felipe Poey', 3: 61-82, 1918.

\section{\& Bruner, $\mathbf{S}[$ tephen] $\mathbf{C}[\mathrm{ole}]$}

Enfermedades del naranjo y otras frutas cítricas. (Diseases of the orange- tree and other citrus.) Cuba Est. Expt. Agron. Bull. 38, 54 p., 1918.

\section{\& Ashby, S[ydney] $\mathbf{F}$ [rancis]; Bancroft, C[laude]}

K[eith]; Nowell, W[illiam] \& Stevenson, John A[lbert]

Diseases of sugar cane in tropical and subtropical America, especially the West Indies. West Indies Bull. 16(4) : 298-300, 1918.

Brief notes on sereh and mosaic disease of sugar cane, the first in Java and the second in Puerto Rico. Deseription of both diseases.

The new cane disease in Cuba. The Louisiana Planter \& Sugar Manuf. 63(6) : 43, 1919.

The author declares that the disease is present in at least three provinces. Quarantine measures are recommended. The author discusses the history of the disease in other countries.

La enfermedad del "mosaico" de la caña de azúcar. (The disease, "mosaic" of sugar cane.) Sección de Sanidad Vegetal, Cuba Circ. 6, 11 p., 1919.

The author gives a popular discussion and recommendations.

The mosaic disease of sugar cane in 1923. (A discussion of the problem to data.) United Fruit Co., Agric. Res. Dept. Pamphlet, 35 p., 1923. (Louisiana Planter 73(1):10-11, (2): 30-32, (3) : 49-52, 1924. The Int. Sugar Journ. 26:469-473, 
1924. A Review by C. A. Barber in Rev. Agric. Puerto Rico $13: 265-272,1924$.)

A popular but very comprehensive discussion of this disease.

Control of sugar eane mosaic. Louisiana Planter 74(10) : 190191, 1925.

The disease spreads slowly in Cuba. Control by inspection and roguing is recommended.

The Panama disease or banana wilt. The United Fruit Co., Res. Dept. Circ. 2, 1928.

A description with suggestions for control.

Enfermedades y plagas de la piña en América Tropical. Rev. Agric. Puerto Rico 26:4-11, 1931. (Bol. Union Panamerica 65 $(1 / 2): 88-103,1931$.)

A popular description of diseases and insects.

The fruit spot of the banana. United Fruit Res. Dept. Bull. 43, 1932.

\section{\& Slocum, A. H.}

The banana fruit spot and its control. United Fruit Co., Res. Dept. Bull. 41, 1932.

Jonge, Mevr. A. E.

Department van den Landvouw in Surinam, Bull. 24, April, 1910.

Kaden, 0. F.

Observations concerning the healthiness of coffee in Costa Rica Trop. Agric. (Trinidad) 9(11) : 350-351, 1932.

The author reports about the healthy conditions of the coffee groves he found in Costa Rica. He states that he only noticed Omphalia flavida, Cercospora coffeicola and a species of Rosellinia, but none of these organisms are of importance. He also observed a non parasitic disease of minor importance. He concludes by giving recommendations to prevent them.

Karling, J. S.

Fungi of British Honduras I. Ann. Mycol. 34(1-2) : 1-10, 1936.

A full description is given of the fungus Hypocrella (Aschersonia) turbinata (Berk.) Petch. observed by the author parasitizing the wax scale (Ceroplastes floridensis) on lime leaves, petioles and fruits in British Honduras.

\section{Kellerman, William Ashbrook}

Mycological expedition to Guatemala. Contribution to Guatemalan Mycology I. Journ. Mycol. 12:137-145, 1906.

Fungi selecti guatemalensis. Exsiccati decade I-II. Journ. Mycol. 12:238-241, 1906; 13:99-102, 1907. 
Dr. Rehm's first report on Guatemalan Ascomycetae. Contribution to Guatemalan Mycology V. Journ. Mycol. 14: 3-7, 1908.

\section{Kern, Frank D[unn]}

The rusts of Guatemala I. Jour. Mycol. 13:18-26, 1907.

The rusts of Guatemala II. Mycologia 3(6):288-290, 1911.

North American rusts on Cyperus and Eleocharis. Mycologia 11 (3) : 134-147, 1919.

\section{\& Whetzel, H[erbert] $\mathrm{H}[\mathrm{ice}]$}

Observaciones en las enfermedades del cafeto y de los árboles cle sombra. (Observations on coffee tree diseases and of the shade trees.) Rev. Agric. Puerto Rico 13(1):7-11, 1924.

Brief popular notes giving the authors' observations on the most prevalent coffee and shade tree (Inga Inga) diseases. They suggest the foundation of a coffee experiment station in the center of Puerto Rico (in the coffee region) to observe and study these diseases in the coffee groves.

\&

Some new or interesting Porto Rican rusts. Mycologia 18(1) : $39-47,1926$.

\section{\& Chardon, Carlos E[ugenio]}

Notes on some rusts of Colombia. Mycologia 19(5):268-276, 1927.

Fungi of Santo Domingo II. Uredinales. Mycologia 20(2): 50-82, 1928.

\section{\& Ciferri $R[$ afael]}

Fungi of Santo Domingo III. Uredinales. Mycologia 22(3): 111-117, 1930.

Supplement to Uredinales. Sci. Survey Puerto Rico \& The Virgin Islands 8(2) : 226-231, 1932.

\& Ciferri R[afael], \& Thurston, H. W.

The rust-flora of the Dominican Republic. Ann. Mycol. 31(12) : $1-40,1933$.

Thurston, Jr., H. W., \& Whetzel, H[erbert] H[ice] Amnotated index of the rusts of Colombia. Mycologia 25(6): 448-503, 1933.

The microcyclic species of Puccinia on Solanum. Mycologia, $25(6)$ : 435-441, 1933.

A study of Puccinia pittieriana on potato. 
\& Toro, Rafael A[ndrés]

Notes on some fungi from Colombia. Mycologia 27(6) :615617, 1935.

This is an annotated list of nine species of fungi, mostly rusts collected by the authors in 1932, including Cerotelium desmium on cotton (Gossypium peruvianum.)

Kick Jr., Jean

Notice sur quelques champignons du Mexique. (Note on some fungi from México.) Bruxelles, M. Hayez 1841. From Bull. Acad. Roy. Belg. VIII, No. 8, 1841.

Klotzsch, J.

Schwanecke.-Collection of fungi. Linnaea 25:364-366, 1852.

Knoche, W., Cruz-Coke, E., \& Pacotet, III.

Der "Palo podrido" auf Chiloe. Ein Beitrag zur Kenntnis natürlichen Umwandlung des Holzes durch Pilze in ein Futtermittel. (The "palo podrido" on Chiloe.) Centralb. Bakt. 2 Abt. 79(15-22) : 427-431, 1929.

\section{Krug, H. P.}

A podridao interna dos capulhos do algodeiro no estado de Sao Paulo. (Internal boll rot of cotton in the State of San Paulo.) Bol. Tech. Inst. Agron. Campinas 23(1): 1-19, 1936.

A brief summarizing account is given of the history, host, range, distribution, economic importance, symptoms, etiology and insect vectors of internal boll rot of cotton. The organisms associated with this disorder are reported to be Nematospora coryli, N. gossypii, yeasts and Penicillium sp. Bacteria appear to be the most active agent in the causation of the disorder. By means of insects vectors it is conveyed to various wild and cultivated Malvaceae, such as Sida and Hibiscus. $N$. coryli was isolated from cowpeas.

Kuijper, J[an] *

Department van den Landvouw in Suriname, Bull. 28:3-10, 1912.

(Phytopathological observations) Suriname, Dept. van den Landb. Verslag (Annual Report) 1911:16-22, 1912.

Brief notes on crop plants reported during the year in Dutch Guiana; it includes a list of fungi determined and studied during the year.

Een fusiclacium-ziekte opheves. De zilver-drand Ziekte der Koffie in Surinam. De gevolgen van Kenkenzout-hounded water voor begieting en bespuiting. Dept. van den Landbouw. Bul. 2: 31, 1912. (Rec. Trav. Bot. Néerlard, 9(4) : 436-451, 1912.)

* Also written Kuyper. 
(Cacao canker) Dept. Landb. Suriname. Bull. 31:29-33, 1913.

Overzich van Koffieziekten in Suriname. (Considerations on coffee diseases in Surinam.) Dept. van den Landbouw, Suriname. Bull. A 311-316, 1913.

Brief description of the coffee diseases occurring in Surinam since 1900.

(Fungi causing diseases in Suriname.) Trav. Bot. Néerland $11(1): 44-53,1914$.

Kurtz, F.

Essai d' un Bibliographie botanique de l' Argentine. (Essay of a botanical bibliography from Argentine.) Bol. Acad. Nac. Ciencias de Córdoba 16:117-208, 1900; 19:221-376, 1913.

T. (E.)

La production du cacao a l' Equateur. (The production of cacao in Ecuador.) Agron. Colon 16(113) :173-174, 1927.

Refers to Marasmius perniciosus.

Labroy, 0.

Les maladies du bananier a Suriname et dans le Central Amerique. (The banana diseases in Surinam and Central America.) Journ. Agric. Trop. 10:328-332, 1910.

A review of the work in America.

Legerheim, G. de

La enfermedad de los pepinos. (The diseases of cucumber.) Rev. Ecuatoriana 2:1-6, 1890.

Observations on new species of fungi from North and South America. Journ. Mycol. 7(1) : 44-50, 1891.

Om förekomstem af europeiska Uredinéer pa Quitós höglätt. Bot. Notiser, Lund, p. 63-66, 1891.

Pucciniosira, Chrysospora, Alvoolaria und Trichospora, vier neuw Uredineen-Gattungen mit tremelloider Entwickelung. (Vorlaufige Mittheilung.) Ber. d. Deutsch Bot. Gesell 9(10) : 344348, 1892.

\section{Larter, L. N. H.}

The highgate banana and Panama disease. Journ. Jamaica Agric. Soc. $40(9): 528-529,1936$.

Lathrop, E. C.

The generation of aldehydes by Fusarium cubense. Phytopathology $7(1): 14-16,1917$. 
Laubert, $\boldsymbol{R}$.

Die Gloeosporium-Faüle der in Deutschland gehandeten Bananenen. (The Gloeosporium rot of banana on the German markets.) Mitt. Gesell. Vorratschutz, 2(2) : 19-21, 1926,

A brief discussion of Gloeosporium musarum on bananas from Jamaica. The author describes the organism and proposes the name G. musarum var. importatum. It has been suggested that this is the same as G. fructigenum f. americana.

\section{Leach, R., \& Wright, J.}

Collar and stem canker of pigeon pea, (Cajanus indicus) caused by a species of Physalospora. Mem. Imp. Coll. Trop. Agric. Trinidad (Mycol. Ser.) 1(4) : 12, 1930.

\section{Leechman, Alleyne}

The radical cure of infectious plant diseases. Journ. Bd. Agric. British Guiana 2(3) : 104-106, 1909.

Leenhoff, J. W. van

A disease of coffee. Puerto Rico Agric. Expt. Sta. Ann. Rpt. $1906: 32,1907$.

Brief report on coffee leaf spot disease caused by Stilbella flavida, Bordeaux mixture is recommended as a control measure.

\section{Lendner, $\mathbf{A}$.}

Un champiagnon parasite sur une Lauracée du genere Ocotea. (A parasitic fungus on a Lauraceae of the genus Ocotea.) Bull. Soc. Bot. Genéve II, 12:122-128, 1921.

\section{Leonard, F. $\mathbf{R}$.}

The storage of Trinidad Citrus fruits. Mem. Low. Temp. Res. Sta. Trinidad 2: 47, 1936.

A report of cold storage studies on grapefruit and oranges. The fungi were Botryodiplodia theobromae, Penicillium digitatum and Colletotrichum gloeosporioides. These fungi and the following additional ones were found in the packing sheds,-Dothiorella (Botryosphaeria) ribis, Oospora sp., Fusarium lateritium var. fructigemum, Eidamia sp. and Aspergillus niger.

\section{Lévéille, J. $\mathbb{R}$.}

Fungi nova-granatense. Triana \& Planchou. Prodomus florae novo-granatensis. Ann. Sci. Nat. 4 S. Bot. 20: 282-300, 1863.

Champignons exotiques (Exotic fungi) Ann. Sci. Nat. III. 2: 167-221, 1884, 3: 38-70, 1885. 
Iewton-Brain, L.

Fungoid diseases of cotton. West Indian Bull. 4:425-467, 1903.

Popular. Refers to root gall (Heterodera radicicola), root knot (Ozonium), wilting or frenching, sore shin or damping off ( $P$. de Barya num), mosaic or yellow blight, red leaf bligltt, angular leaf spot, leaf blight (Sphacrella gossypina) areolate mildew (Ramularia areola), eotton rust (Uredo gossypii), shedding of bolls, cotton boll rot (Bacillus gossypinus), and anthraenose (Colletotrichum gossypii.)

Disease-resisting varieties of plants. West Indian Bull. 4(1): $48-57,1903$.

Discussion of the subject giving a review of the work done so far.

Lectures on the diseases of the sugar cane. Barbados, Pamphlet No. 29, 1904.

West Indian Anthracnose of cotton. West Indian Bull. 5(2): 178-194, 1904.

A report on this disease including symptoms, a deseription of the fungus (Colletotrichum gossypii) and the results of experiments.

Review of the principal fungoid diseases of the sugar cane. West Indian Bull. 6(1) : 33-37, 1905.

A discussion of the rind disease (Trichosphaeria sacchari), root disease (Marasmius sacchari). Says that Marasmins seminstus attacks banana in the West Indies.

Fungous diseases of cacao. West Indian Bull. 6(1) : 85-94, 1905.

Fungoid diseases of cotton. West Indian Bull. 6(2) : 117-123, 1905.

This paper contains brief discussions of rust (Uredo gossypii), leaf spot (Cercospora gossypina), mildew, anthracnose (Colletotrichum gossypii), black boll, dropping of bolls.

Levy, H. I.

The banana disease and other enemies of the plant in Costa Rica. Journ. Jamaica Agric. Soc. 14:241-247, 1910.

Not very definite.

Lindau, $\mathbf{G}$.

Beiträge zur Pilze flora Süd-Amerikas. Einleitung. Hedwigia 35: 202-207, 1896.

Sphaeriales. In Engler und Prent. Die Naturaliche Pflanzenfamilien, Teil I .Abt. 1:421, 1897.

Fungi Lichens: In Perkins J., Beiträge sur Flora von Bolivia. Bot. Jahrb. 49: 173, 1912. 


\section{Lindquist, Juan C.}

Algunos hongos nuevos parásitos de las plantas cultivadas de la República Argentina. (Some new parasitic fungi of the cultivated plants in the Argentine Republic.) Rev. Agron. Univ. Nac. La Plata (Argentina) 19:197-210, 1930.

Sobre la presencia de la Phytopthora capsici en la República Argentina. (On the occurrence of Phytophthora capsici in the Argentine Republic.) Physis 11:170-174, 1932.

La "quemadura" de las hojas de narcisos y junquillos. (Stagonospora Curtisii) (Leaf scoarch of narcissus and jonquils. Stagonospora Curtissi.) Rev. Argent. Agron. 2(7) : 237-244, 1935.

The author gives the description of the disease and control measures of the fungus Stagonospora Curtissi the eausative agent on Narcissus pseudonarcissus and $N$. tazetta.

Lister, A.

Mycetozoa of Antigua and Dominica. Journ. Bot. 36:112-122, 1898.

Mycetozoa of Antigua. Journ. Bot. 36:378-379, 1898.

\section{Lizer, Carlos}

Quelques notes pour servir de complement au recueil de Mr. L. Hauman-Merk sur. "Les parasites vegétaux des plantes, cultivées en Argentine et dans les régiones limitrophes." (Some notes to serve as a complement to the work of Mr. L. HaumanMerk on "The vegetable parasites, of cultivated plants in Argentine and adjoining regions.") Ann. Soc. Cien. Argentina $78: 5-17,1914$.

\section{Lloyd, C[urtis] G[ates]}

\section{Lycoperdum albidum. Mycological Notes 42:582, 1916.}

Polystictus ninuosus. Mycological Notes 45:626, 1917.

Notes on Xylarias. Mycological Notes 48:675-677, 1917.

Xylaria fumbriata. Mycological Notes 51: 726, 1917.

\section{Loew, [Carl Benedict] Oscar}

Diseases of tobacco. Puerto Rico Agric. Expt. Sta. Ann. Rpt. 1907 : 16-18, 1908.

The fermentation of the cacao and coffee. Puerto Rico Agric. Expt. Sta. Ann. Rpt. 1907: 41-55, 1908. 


\section{López Domínguez, $\mathbf{F}[$ rancisco] $\mathbf{A}[$ ntonio]}

Has yellow stripe or mottling disease any effect on the sugar content of cane juice? Journ. Dept. Agric. Puerto Rico 3 (4) : 47-64, 1919.

Analytical studies which indicate that the disease does not affect materially the sugar content of the juices unless the stalk is drying.

Chemical variations in yellow striped cane. Ins. Expt. Sta. Puerto Rico Ann. Rpt. 1920:77-78, 1920.

La caña Uba y su rendimiento de azúcar en Puerto Rico. (Yield of the Uba Cane in Puerto Rico.) Ins. Expt. Sta. Puerto Rico. (Eng. \& Spanish.) Bull. 28, 1923.

The author points out the importance of this variety to save the sugar-cane industry from the mosaic epidemic.

El matizado o mosaico de la caña: Sus síntomas sobresalientes. (Sugar cane mosaic: Outstanding symptoms.) La Vida Agrícola, Lima, Perú, 4(46) : 803-806, 1927.

Informe Anual del Director Estación Experimental Insular. Agric. Puerto Rico 1925-26: 1-62, 1927.

Contains records of a fow diseases.

Mosaico de la caña de azúcar. Inform. \& Mem. Soc. Ingen. Perú 10(30):445-455; $11: 466-478,1928$.

Popular.

El Matizado de la caña. Método para su represión. (Sugar cane mosaic. Method for its control.) La Vida Agrícola, Lima, Perú 5(50) : 89-98, 1928.

El mosaico de la caña de azúcar. (Sugar cane mosaic.) Est. Expt. Agric. de la Soc. Nac. Agraria de Perú. Circ. 10, 23 p., 1928.

Conference before the Engineers' Society of Perú. The author describes the disease and reviews the work done to eradieate it. He advises the planting of immune or resistant varieties.

Macbride, Thomas Huston, \& Smith, C. L.

Nicaraguan myxomycetes. Iowa Univ. Bull. Lab. Nat. Hist. 2 (4) : 377-383, 4(1) : 73-75, 1896.

\section{Madariaga, A.}

Plagas y enfermedades del maíz. (Diseases and pest of corn.) Rev. Agric. (México) 4:449-456, 1919.

A discussion of Puccinia and Ustilago maydis on Indian corn. 


\section{Magalhaes, Octavio}

Formas anomalas do Oidum "Brasilienses". Bol. Inst. Brasil Sci. 2(10) : 338-342, 1926.

\section{Magnus, Paul Wilhelm}

Über dei parasitische Pilze Argentinius (On the parasitic fungi of Argentina). Hedwigia 48:147-151, 1908.

\section{Maire, Renó}

Champignons de Sao Paulo (Brésil).-I. (Fungi from Sao Paulo, Brasil-I.) Ann. Mycol. 6:144-153, 1908.

\section{\& Tison, A.}

Nouvelles recherches sur les Plasmotiophoracées. (New investigations on the Phasmodiophoraceae.) Ann. Mycol. 9: 226-246, 1911.

\section{Mann, C[harles] W[illiam]}

The handling of Puerto Rican oranges, grapefruits and pineapples. Puerto Rico Ins. Expt. Sta. Bull. 7, 36 p., 1914.

Narchionatto, Juan B.

Nueva contribución al conocimiento de los hongos parásitos de las plantas cultivadas. (New contribution to the study of the parasitic fungi of cultivated plants.) Rev. Eac. Agron. Univ. La Plata III, 15 : 7-21, 1924.

Fitoparásitos de la Argentina nuevos o poco conocidos. (New of little known plant parasites from Argentine.) Physis 8: 367-372, 1926.

Lias enfermedades económicas de nuestros árboles frutales. (Economic diseases of our îruit trees.) Primera conferencia Nacional de Fruticultura, Feb. 28 a Mar. 2, Dolores (Córdoba) 1926: 97-108, 1926.

A discussion of diseases in Spain.

El "bitter-pit" de la manzana. (Bitter-pit of apple.) Rev. Centro Estud. Agron. y Vet. Univ. Buenos Aires. 20(132): 325-328, 1927.

Una fitonosia nueva (La "Koleroga" del café). (The koleroga of coffee.) Physis 8(31): 554-557, 1927.

A description of this disease which is caused by Cortioinm koleroga. This fungus attacks Ilex paraguayensis and Nerium oleander in Argentina.

Fitoparásitos de la Argentina nuevos o pocos conocidos. II (New or little known plant parasite from Argentina, II.) Rev. Fac. Agron. Univ. Nac. La Plata. 18:21-29, 1928. 
La presencia de la Plasmodiophora brassicae en la República Argentina. (The occurrence of Plasmodiophora brassicae in the Argentine Republic.) Physis, Rev. Soc. Argentina de Ciene. Nat. 9: 455-456, 1929.

La lucha contra el "carbón volador" del trigo. (The fight against the "loose smut" of wheat.) Argentina, Bol. Min. Agric. 28(2) : 229-231, 1929.

Brief notes on the treatment of loose smut of wheat caused by Ustilago tritici (Pers.) Jens.

Las "fusariosis" del trigo y del maíz. Wheat and corn fusariosis.) Argentina Bol. Mins. Agric. 30(3) : 189-192, 1931. Discussion of fusariosis on wheat and corn.

Dos informes sobre la roya "amarilla" del trigo. (Report on the yellow rust of wheat.) Argentina Mins. Agric. 836, 20 p., 1931.

Brief report on this rust with lengthy tables on its distribution in Argentina.

Notas críticas sobre la presencia de la "Puccinia glumarum" en la República Argentina. (Critical notes on the occurrence of Puccinia glumarum in the Argentine Republic.) Physis $10: 362-367,1931$.

Sobre algunos hongos parásitos de las gramíneas tóxicas para el ganado. (Some parasitic fungi of graminaceae toxic to live stock. Bol. Min. Agric. Nac. Buenos Aires, 29:457-462, 1931.

La roya amarilla clel trigo en la zona central. (The yellow rust of wheat in the central zone.) Bol. Min. Agric. Nac. Buenos Aires 30(4) : 215-218, 1931.

The author states that as in other cereal producing countries, yellow rust of wheat, Puccinia glumarum is the first to appear in Axgentine, followed by yellow rust $P$. triticina and then by black rust $P$. graminis. Among the grass hosts of $P$. glumarum are Bromus unioloides and Hordeum jubatum.

La presencia de la roya "amarilla" (The presence of the "yellow" rust.) Min. Agric. Nac. (Buenos Aires) Sec. Prop. \& Inform. Circ. $836: 3-5,1931$.

A brief, popular account of the symptoms and life history of yellow rust of wheat caused by Puccinia glumarum. Data on susceptibility of varieties and distribution.

Las "helmintosporiosis" de la cebada en la República Argentina. (The helminthosporioses of Barley in the Argentine 
Republic.) Physis, Rev. Soc. Argentine Cien. Nat. 11(38): 107-114, 1932.

Notes are given on the symptoms an etiology of three barley diseases occurring in Argentine. (Helminthosporium teres, H. gramineum and H. sativum.) Brief descriptions of the organisms are included.

Notas sobre algunos Sclerotium parásitos de las plantas económicas. (Notes on some Sclerotium parasitic of economic plants.) Physis 11:301-305, 1933.

Notas de patología vegetal. Contribución al conocimiento de las enfermedades de las plantas provocadas por los hongos. (Notes on plant pathology. A contribution to the knowledge of the plant diseases induced by fungi.) Rev. Fac. Agron. Univ. Nac. La Plata 19(3): 407-426, 1933.

Notes are given of several fungous diseases of crop plants observed in the Argentine Republic for the first time.

Enfermedades del trigo poco conocidas y radicudas en la región oeste de la zona triguera. (Little known wheat diseases indigenous to the western section of the wheat growing area.) Argentinie Min. Agric. (Buenos Aires) Bol. 36(4) : 293-299, 1934.

The following fungi were isolated from diseased wheat in Argentine since 1929. Gibberella saubinetti, Helminthosporium sativum, ophiobolus graminis, Alternaria peglionii, Fusarium moniliforme var. subglutinans.

\section{\& Millán, Roberto}

Certificación de la "semilla" de papa. (Potato "seed" certification.) Argentine, Bol. Min. Agric. (Buenos Aires) 36(4): 301-302, 1934.

Brief account of quarantine measures, in Argentine, Brazil and Uruguay for the exclusion of potato diseases with special referenca to those of virus origin. Other provisions are mentioned in regard to Phythophtora infestans, Actinomyces scabies and Corticium vagum.

Argentine Republic: the overwintering stages of pear and apple scab. Int. Bull. Plant Prot. 9(1):1-2, 1935.

Notes are given on the prevalence of apple and pear scab, where the perithecial stage of the two causal organisms (Venturia inaequalis and $V$. pirina) was observed for the first time in 1934.

Degeneración de la papa en los eultivos del país. La Chacra (Buenos Aires) 5(60): 48, 58, 71, 1935.

Argentine Republic: yellow rust in the wheat-growing region. 
Behaviour of the cultivated varieties vis-a-vis the disease. Int. Bull. Plant. Prot. 9(4) : 79-80, 1935.

Regional studies of the distribution of yellow rust (Puccinia glumarum tritici) in Argentine.

Argentine Republic: Species of Fusarium existing in the country. Int. Bull. Plant Prot. 9(6): 125, 1935.

Review of study of Fusarium occurring in Argentine made by 0 . Carrera.

Argentine Republic: new studides on the "lepra explosiva" of the orange. Int. Bull. Plant Prot. 9(8) : 173-175, 1935.

The author discusses the etiology of the citrus disease known in Argentine as "Lepra explosiva". He concludes that the evidence is that Amylirosa aurantium and Cladosporium herbarum var. citricolum are not responsible for the maladies. $\mathrm{He}$ also excludes physiological factors, based on experiments, and is inclined to believe that the disturbance is due to a virus. He recognized two forms of the disease and observed that it facilitates the infections of Colletotrichum gloeosporiodes and other pathogens. Measures of control are under study.

Marins Ramos, C. S.

O combate do mosaico (The fight against mosaic.) Bot. Agric. Bahia (Brazil) 15:29-33, 63-65, 1926.

Novo methodo para combatir apropagacao de "mosaico na canna de assucar". (New method of fighting the propagation of "mosaic of sugar cane".) Bol. Min. Agric. Ind. e Comm. Brazil 15:793-795. (Correio Agric. Soc. Bahiana Agric. 4: 199-201, 1926.

This paper on Alfaro's studies on the migration of Aphis maidis and recommends planting so that the cane can make a maximum growth before the period of migration.

Marsh, R. W.

Inoculation experiments with Nematospora gossypiin, Ashby \&

Nowell. Ann. Bot. 40(160): 883-889, 1926.

Greenhouse tests showed that the fungus could not infect mature cotton hairs or bolls that were not wounded. N. Coryli and Spermophthora gossypii were shown to be parasites of injured bolls.

Marshall, R. C.

Observations on cypre (Cordia alliodora L.) in Trinidad with special reference to canker disease. (Puccinia cordia (P. Henn.) Arthur.) Part II. Silviculture. Mem. Imp. Coll. Trop. Agric. Trinidad 3:7-8, 1930.

Discusses the "cypre" (Cordia alliodora L.) as a forest tree with special reference to the canker disease caused by the parasitic rust fungus Puccinia cordiae (P. Henn.) Arthur, and gives control measures. 


\section{IMartínez, Augusto $\mathbf{N}$.}

Una enfermedad del cacao. Quinta Normal, Estac. Expt. (Ambato, Ecuador) Circ. 6, 13 p., 1916.

Cacao diseases in Ecuador. Soc. paper 676. Proc. Agric. Soc. of Trinidad and Tobago. 17(1):28-36, 1917. Popular. Cause not given.

La Hemileia vastatrix del café. (The Hemileia vastatrix of coffee.) Quinta Normal, Ambato (Ecuador) Circ. 15, 5 p.. 1923.

Martínez, I.

Enfermedad del cacao y medios de combatirlas. Bol. Circ. Gen. Agric.. (México) Rev. Agric. 2(6) : 520-532, 1912.

Martínez García, Manuel

Catálogo de la flora y fauna del Estado de Oaxaca. (Catalog of the flora and fauna of the State of Oaxaca.) México, Imprenta del Estado, Oaxaca, México Part. 2, 116 p., 1891.

INartins, I. F. P. von

Dexas plantarum mycetoidearum quas in itinere Brasiliensı observavit C. Ph. a Martins Nova Acta Acad. Coes Nat. Cur. $10: 502-512,1821$.

\section{Martyn, E[ldred] B [ridgeman]}

The Sclerotium disease of coffee and its occurrence in this colony. Agric. Journ. Brit. Guiana. 2(1) : 7-10, 1929.

The fungus is Sclerotium coffeicolum. Attacks Liberian coffee. Also Robusta, Uganda and Moca. Has been found on Canephora deweveri (a tree), C. arabica and Cecropia peltata. The author deseribes the symptoms and gives methods of control.

Mosaic disease of cane. Agric. Journ. Brit. Guiana. 2(2): 112, 1929.

A brief note.

The gumming disease of sugar cane. Agric. Journ. of Brit. Guiana. 2(3): 208, 299, 1929.

A note.

The pokkah-bong and twisted top diseases of sugar cane. Agric. Journ. Brit. Guiana. 2(3): 209, 210, 1929.

A note.

Botanical and mycological division. Agric. Journ. of Brit. Guiana. 2(4) : 222-224, 1929.

Mentions Sclerotium coffeicolum on coffee. A wilt of coffee resembling phloem necrosis of Surinam. Cercospora coffeicolum of coffee. Damping off of citrus seedlings. 
Witch-broom disease of cacao and its control. Agrie. Journ. Brit. Guiana. 2(2): 109-110, 1929.

A review of paper by this title written by Stell. Bull. Dept. Agric. Trinidad \& Tobago 21 (Part 3), 1928.

The Sclerotium disease of coffee: Some notes on the origin of the disease its outbreak, and control. Agx. Journ. Brit. Guiana 3(1) : 28-34,1930. (Trop. Agric. (Trinidad.) 7(6) : 165, 1930.)

Continuation of previous work given additional details from those in the above citation.

British Guayana: Erste Feststelhung ron Fusarium cubense in der Kolonia. Int. Auz. Pflanzenchutz 4: 106, 1930.

Botanical and Mycologieal Division. Annual Report 1929. Agric. Journ. Brit. Guiana. 3(4) : 226-233, 1930.

This report states that mosaic disease of sugar eane is not yet known in British Guiana. Gives brief notes of several diseases of erop plants.

British Guiana: Fusarium cubense discovered in the colony for the first time. Internal Bull. of Plant Protect. 4(7):101$102,1930$.

The disease detected on wilted plantains. (Musa paradisiaca.)

Plant diseases. Agric. Journ. Brit. Guiana. 4(2): 95-100, 1931. Notes on several common diseases.

Report of the Botanical and Mycological Division for the year 1932. Divisional Repts. Dept. of. Agric. British Guiana 1932 : 117-121, 1932 .

This report mentions mosaic and Fusarium monitiforme on sugar cane, Acrothecium lunatum, and Clasterosporium punctiforme on rice, and phloem necrosis on eoffee.

Botanical and myeological investigations. British Guiana Almin. Rept. Dijector Agric. 1931:28-29, 1932.

Reports a non infections chlorosis of sugar cane.

Preliminary list of diseases of economic plants in British Guiana. Kew. Bull. Misc. Inf. 1933: 107-110, 1933.

Notes on some cliseases of local economic plants and their relation to enviromment. Agric. Jour. British Guiana. 4(2):95$100,1931$.

Brief notes. Most important is Fusarizm cubense. 
Note on diseases of rice. Dept. Agric. Brit. Guiana Rice, Bull. 1. Part IV, 1934.

A brief note listing Tilletia horrida Tak., Sclerotium oryzae Catt., Fusarium moniliforme sp., and Gibberella (Lisea) Fujikuroi (Saw.) Wr.

Report of the Botanical and Mycological Division for the year 1932. British Guiana Dept. Agric. Divisional Rpts. 1932: 117-121, 1934.

A note on plantain and banana diseases in British Guiana with special reference to wilt. Agric. Journ. Brit. Guiana. 5(2) : 120-123, 1934.

This article confirms the presence of banana wilt due to Bacterium solanacearum in the Colony and its similarity to that disease known as "moko" in Trinidad. The symptoms of the disease are discussed.

Report of the Botanical and Mycological Division for the year 1933. British Guiana Dept. Agric. Divisional Repts. 1933: 105-111, 1934.

Several diseases of more or less importance are reported.

Report of the Botanical and Mycological Division for the year 1934. British Guiana Dept. Agric. Div. Rpt. 1934: 105-108, 1935.

Among the items mentioned in this report are citrus seab (Sporo. trichum citri); a wilt of coconut trees; cacao witches' broom (Maras. mius perniciosus); pineapple "black eye" disease and guava sun crack of fruits.

The diseases of rice in British Guiana. Agric. Journ. Brit. Guiana 7(2): 142-143, 1936.

The author reports the following diseases on rice in British Guiana: blast (Piricularia Oryzae); man rice (Fusarium moniliforme) Mildewed heads Acrothecium lunatum and Claterosporium punctiforme); a sclerotium disease (Sclerotium Oryzae), and bunt (Tilletia horrida)

Mason, ‥ W.

Annotated account of Fungi received at the Imperial Bureau of Mycology. List II, Fascicle I, 1928.

ILason, T. G.

Ligneous Zonation and die-back in lime (Citrus medica var. acida) in the West Indies. Sci. Proc. R. Dublin Soc. N. S. 17 : 25-31, 255-262, 1923.

The results of studies. 


\section{IMassee, G[eorge]}

Mycological notes II: Journ. Mycol. 6:178, 1891.

Records Sarcomyces vinosa Mass. as new genera and species from Venezuela.

Trichosphaeria, Massee, Ann. Bot. 7:515-532, 1893.

Coffee disease in Nicaragua. Bul. Roy. Bot. Gard. Trinidad $3(20): 182,1899$.

Notes on Stilbum flavidum in Nicaragua with recommendations to use Bordeaux mixture to control it.

Coffee disease in New World. Roy. Bot. Gard. Kew. Bul. Misc. Inf. 8: 337-341, 1909.

The author gives a detailed description of coffee leaves which is supposed to be known in Central and South America. For some years it was attributed to the fungus Sphaerostilbe flavida.

Exotic fungi. Roy. Bot. Gard, Kew. Bull. Misc. Inform. 1: 1-6, 1910.

Fungi exotici XIII. Kew. Bull. Misc. Inf. p. 189-191, 1912.

\section{Mathews, V. D.}

Studies in the genus Pithium. North Carolina Univ. Press Pamph. p. 133, 1931.

\section{Mathews, W. H.}

The agricultural progress of the pomeroom between the years 1905-1917. British Guiana Journ. Bd. Agric. 12(1):6-10, 1919.
A brief report.

\section{Matz, Julius}

Algunas enfermedades del follaje en las plantas. (Foliage diseases.) Rev. Agric. Puerto Rico 2(12) : 624-625, 1919; 3(7) : 20-24, 1919.

Popular notes mentioning Rhizoctonia, Pellicularia, mildew, etc.

Algunas observaciones respecto a la sarna (scab.) del citro en Puerto Rico. (Some observations on citrus scab in Puerto Rico.) Rev. Agric. Puerto Rico 2(3):40-41, 1919.

Brief popular notes.

Citrus spots and blemishes. Puerto Rico Ins. Expt. Sta. Circ. 16, 8 p., 1919.

Popular account of the most common diseases of citrus in Puerto Rico, suggesting in some instances method of control to preserve good appearance for the market. 
Report of the division of plant pathology and botany. Puerto Rico Ins. Expt. Sta. Ann. Rpt. 1919: 35-36, 1919.

Records of diseases of occurrence during the year.

Enfermedad de la raíz de la caña de azúcar. (Root disease of sugar eane.) Rev. Agr. Puerto Rico. 2(3):38-39, 1919.

Brief popular note. Attributes the cause to a Rhizoctonia and Pythium.

Infection and nature of the yellow stripe disease of cane. Journ. Dept. Agric. Puerto Rico. 3(4) : 65-82, 1919.

Results of experiments and histological studies. The author describes a granular plasma in some of the cells which he believes may be a cause of the disease.

Observaciones hechas en la región de Maricao con respecto a las enfermedades del café y del guineo. (Observations made in the region of Maricao in regard to the coffee and banana diseases.) Rev. Agric. Puerto Rico. 5(5): 15-18, 1925.

Brief report of a trip to the coffee district of Maricao, (Puerto Rico). The author gives his observations on eoffee and banana diseases.

Pudrición de la base de la "roselle". (Rot of the base of roselle.) Rev. Agric. Puerto Rico. 5(5):18-20, 1920.

Popular.

Últimos desarrollos en la patología de la caña de azúcar. (Last development in the pathology of sugar cane.) Insular Expt. Sta. Puerto Rico. Circ. 33: 32-36, 1920.

Paper read before the Sugar-cane Technologists' Association of Puerto Rico. Reviews the work done in sugar-eane pathology and devoted special attention to mosaic disease.

Gumming disease of sugar cane in Puerto Rico. Phytopathology (Abstract) 10(9):429, 1920.

Investigations of root disease of sugar cane. Journ. Dept. Agric. Puerto Rico 4(1): 28-40, 1920.

A thorough discussion of the subject, giving results of experiments on observations on Marasmins, Rhizoctonia, Pythium and Trichoderma spp.

El mal del guineo. (Banana wilt.) Ins. Expt. Sta. Puerto Rico. Circ. 25, 7 p., 1920. (La Hacienda 20:43-45, 1925.) 
The gumming disease of sugar eane. Facts About Sugar. 15: 258-259, 1922.

Popular.

Citrus and pineapple fruits rots. Puerto Rico Ins. Expt. Sta. Bull. 24, 1920.

A new vascular organism in sugar cane. Journ. Dept. Agric. Puerto Rico 4(1): 41-46, 1920.

Short paper describing Plasmodiophora vascularum Matz.

Report of the Division of plant pathology and botany. Puerto Rico. Ins. Expt. Sta. Ann. Rpt. 1919-20: 91-93, 1920.

Gumming of sugar cane in Puerto Rico. Sugar 22:282-283, 1920.

A description and history of the disease.

La gomosis de la caña de azúcar. (Gumming disease of sugar cane.) Sugar 22:363-364, 1920.

Spanish translation of an earliex publication.

Observaciones en la gomosis de la caña en Puerto Rico. (Observations on gummosis of sugar cane in Puerto Rico.) Rev. Agric. Puerto Rico 6(4) : 33-39, 1921.

Popular.

El salcocho de los semilleros de tabaco. (Damping-off of tobacco seed beds.) Puerto Rico. Ins. Expt. Sta. Circ. 55, 6 p., 1921.

Popular account giving eause and methods of control.

Annual Report of the Division of Plant Pathology and Botany for the year 1920-21. Puerto Rico Ins. Exp. Sta Amn. Rept. p. 51-58, 1921.

La enfermedad de la raíz de la caña de azúcar. (Sugar cane root disease.) Puerto Rico Ins. Expt. Sta. Circ. 56, 12 p., 1921.

Popular discussion of this complex subject.

Una enfermedad dañina de la habichnela. (A harmful disease of beans.) Puerto Rico Ins. Expt. Sta. Cire. 57, 8 p., 1921. The disease is eaused by Rhizoctonia microsclerotia.

The Rhizoctonias of Puerto Rico. Journ. Dept. Agric. Puerto Rico 5(1) : 2-30, 1921. 
Annual Report for the Division of Plant Pathology and Botany for the year 1920-21. Ins. Expt. Sta. Puerto Rico. Ann. Rpt. 1920-21: 52-53, 1921.

La enfermedad de la raíz en el café. (Root disease on the coffee.) Est. Expt. Ins. Puerto Rico. Circ. 32, 10 p., 1920.

A popular description of the coffee root disease caused by the fungus Rosellinia sp.

Gumming disease of sugar cane. Journ. Dept. Agric. Puerto Rico 6(3) : 5-21, 1922.

This paper gives the results of the first studies on this disease in Puerto Rico. The author tells of the finding of the disease, gives something of the economic considerations and varietal resistance.

La gomosis de la caña de azúcar. Puerto Rico Ins. Expt. Sta. Cire. 20, 8 p., 1922.

Popular discussion of the preceding.

Observaciones sobre la gomosis de la caña en Puerto Rico. (Observations on the gummosis of sugar cane in Puerte Rico.) Rev. Agric. Puerto Rico 8(4) : 5-14, 1922.

Popular.

La gomosis de la caña. (Gummosis of sugar cane.) Sugar 24: 352-354, 1922.

Popular.

Dry top rot of sugar cane. A vascular disease. Journ. Dept. Agric. Puerto Rico 6(3) : 28-47, 1922.

Description of the disease and experimental results. Phytophthora vascularum Matz.

Informe de la Estación Experimental Insular. Informe de la Div. de Botánica y Patología. (Report of the Div. of Botany and Pathology.) Rev. Agric. Puerto Rico. 8(2) : 63-65, 1922.

Contains reports on gumming disease, Plasmodiophora disease, mosaic of sugar eane and minor diseases of other crops.

Recent developments in the study of the nature of mosaic diseases of sugar cane and other plants. Journ. Dept. Agric. Puerto Rico. 6(3) : 22-27, 1923.

The author reviews the work of Iwanowski, Kunkel and Palm on the intracellular bodies.

Recientse investigaciones en el estudio de la naturaleza del mosaico de la caña de azúcar y otras plantas. (Recent investiga- 
tions on the studies of the nature of mosaic disease of sugar cane and other plants.) Rev. Agric. Puerto Rico. 9(4): 9-12, 1922.

Popular discussion of an article that appeared in Journ. Dept. Agric. Puerto Rico. 6(3): 22-27, 1923. (Preceding eitation.)

Naturaleza del mosaico de la caña. (Nature of the mosaic disease of sugar cane.) Sugar 25:222-223, 1923.

A discussion of bodies found in mosaic plants.

Root knot of sugar cane in Puerto Rico. Facts About Sugar, $11: 93-94,1925$.

A popular discussion.

Root knot on sugar cane in Puerto Rico. Phytopathology 15 (9) : 559-563, 1925.

Maublanc, André

Espéces nouvellew de champignons inférieurs. (New species of lower fungi.) Bull. Soc. Mycol. France, 20:165-171, 21:8794, 1905.

Sur une maladis des feuilles du papayer. "Carica Papaya." (On a disease of the leaves of Carica papaya.) A Lavoura. 16:208-212, 1913. (The same paper is published also in Portuguese under the title "Sobre uma molestia do mamoeiro (Carica Papaya L.) A Lavoura 16:204-208, 1913.)

\section{\& Rangel, E[ugenio] [do Santos]}

Alguna fungos do Brasil novos on mal conhocidos. (Some fungi of Brasil new or badly known.) A Lavoura 18:1932, 1914.

Le Stilbum flavidum Cooke, parasité du Caféier et sa place dans la clasification. (The Stilbum flavidum Cooke, coffee tree parasite and its place in the classification. (Comp. Rend. Hendom. d. Seances d l'Acad. Sci. de Paris 127, 1913. (Rev. Min. Agr. \& Com. Bogotá Vol. II, 1916.)

Contribution á l'étude de la flora mycologique brasiliene. (Contribution to the study of the mycological flora of Brazil.) Bull. Soc. Mycol. France. 36:33-43, 1920.

Observations sur quelques champignons du Bresil. 1. Sur un parasite des feuilles de Mikania. Observations on some fungi from Brazil. I. on a parasite of the leaves of Mikania.) Arch. Bot. Bull. Mens. 2: 121-129, 1928.

\section{May D[avid] W[illiam]}

Diseases of cane. Puerto Rico Agric. Expt. Sta. (Mayagüez) Bull. 9: 38-39, 1910. 
Kavangire in Puerto Rico. (A reply to E. W. Brandes.) Facts About Sugar 21:522, 1926.

Controversial.

Kavangire in Puerto Rico. (A reply to F. S. Earle.) Facts About Sugar 21: 1096, 1926.

Controversial.

\section{Mayor, Eugenio}

La mancha de "los cafetos en el Departamento de Cundinamarca'. (The coffee tree spot in the Department of Cundinamarca.) Rev. Nac. Agric. (Bogotá) 6:135-152, 1911.

The author attributes the yellowing of coffee in the Department of Cundinamarca (Colombia) to the fungus Hemileia vastatrix. He believes that it has been confused with Stilbella flavida Cooke. He gives description of both fungi and means of control.

El amarillamiento de los cafetos en el Departamento de Cundinamarca. (The yellowing of coffee in the Department of Cundinamarea. Rev. Nac. Agric. (Bogotá) 6:331-340, 1912.

The author attributes the yellowing of coffee in the Department of Cundinamarca (Colombia) to the fungus Phthora vastatrix D'Herelle. $\mathrm{H}_{\theta}$ describes the disease and recommends burning of infested trees as a control measure.

Contribution a' l'étude des uredinées de Colombia. In Fuhr. mann, O. Voyage d' exploration Scientifique en Colombia. Mem. Soc. Nenchat. Sci. Nat. 5(2) : 442-599, 1914.

\section{INcCallan, $\mathbb{E}[$ rnest] $\mathbf{A}[$ lbert]}

Report of seed potato inspection. Bermuda Agric. Dept. Agric. Bull. 1922: 4-7, 1922.

A record of the amount of leafroll and mosaic in plants grown from the same stock in Bermuda and Nova Scotia.

Bermuda: Eine Krankheit der Lilium longiflorum und die "Aster yellows". (Bermuda: A disease of Lilium longiflorum and the aster yellows.) Inst. Anz. Pflanzenschutz 1: 65, 1927.

\section{IMcClelland, Tomás 'B.}

The coffee leaf spot (Stilbella flavida) in Puerto Rico. Puerto Rico Agric. Expt. Sta. (Mayagüez) Bull. 28, 12 p., 1921. (Spanish ed. 9 p. 1922.)

This fungus attacks Coffea arabica, Bryophyllum calycinum, Andira inermis, Inga vera, Citrus and other plants. Gives suggestions for its control. 
\& Tucker, C[larence] $\mathbb{M}[$ itchell]

Green scale Coccus viridis, a new pest in coffee and citrus. Agric. Notes (Mayaguiez) Puerto Rico. No. 48, 2 p., 1929.

Attacked by two fungi, one of which has been identified as Cepha. losporium lecanii.

\section{Mc Kenney, $\mathbb{R}$ [andolph] $\boldsymbol{E}$ [vans] $\mathbf{B}$ [ender]}

The Central American banana blight. Science n. s. 31(802):750, 751, 1910.

\section{Medina, Vicente}

II control de enfermedades y plagas en los semilleros y víveres de café. (Control of diseases and pests in the coffee seed beds and murseries.) Bol. Agr. (Puerto Rico.) Dept. Agric. $1(7): 2-3,1931$.

The anthor discusses in popular style the subject of coffee diseases in seed-beds.

\section{Mejía F. Ramón}

La arachosis del cafeto. (Coffee tree arachnosis.) Rev. Cafetera de Colombia, 3(28-29) : 1043-1045, 1931.

The author believes that two causes are responsible for this trouble (1) Climatic conditions and the position of the groves that prevent the use of shade trees. (2) The invasion of an Arachnidae (not determined). He describes the organism and suggests spraying (300 grams of common soap, 100 grams of creolin and water to make 20 liters) to control it.

\section{Menéndez Ramos, R[afael]}

El suelo no puede ser responsable del matizado de la caña. (The soil can not be responsible for the mottling of sugar cane.) Rev. Agric. Puerio Rico. 11(3): 13-20, 1923.

The soils is not the cause of the disease. A thorough discussion.

Sigamos con el matizado. (Let us continue with the mottling disease.) Rev. Agric. Puerto Rico. 11(5) : 23-28, 1923.

Popular discussion giving further data to the preceding.

Sugar cane disease. Ins. Expt. Sta. Puerto Rico. Ann. Rpt. $1922-23: 21-22,1923$.

A brief record.

La cal como enmienda. (Lime as an amendment.) Ins. Expt. Sta. Puerto Rico. Circ. 7\&, 17 p., 1923.

Discussion on the agricultural uses of lime. The author discusses the popular belief that lime is a cure of sugar-cane mosaic. He declares that lime is not a cure for the disease. 
Estudios sobre el mosaico de la caña. Movimiento del virus a través del tallo en el caso de infecciones secundarias. (Studies on sugar cane mosaic disease. Movement of the virus through the stalk in cases of secondary infections.) Rev. Agric. Puerto Rico. 13(4): 219-226, 1924. (Rev. Appl. Mycol. 4: 244. Louisiana Planter \& Sugar Manuf. 73(25):488-489. Rev. Agric. Com. \& Trab. Cuba 7(5):31-33, 1925.)

All the euttings from a stalk of cane on which only a part of the leaves are mottled, will probably produce diseased plants.

Mosaic disease and method of control. Planter \& Sugar Manuf. 75(25) : 487-498, 1925. (Rev. Appl. Mycol. 5: 329, 1925.)

A popular discussion of the subject.

La enfermedad mosaico y los métodos de combatirla. (The mosaic disease and method to control it.) El Mundo Azucarero $13(8)$ : 241-245, 1926.

A translation of the previous eitation. Planter \& Sugar Manuf. $75: 487-489,1925$.

The control of sugar cane mosaic in the West Indies. Ref. Book of the Sugar World (The Planter \& Sugar Manuf.) 5: 38-41, 1927.

A short paper giving extensive data on field studies.

El comportamiento de la enfermedad del mosaico en las variedades POJ-2714, 2725, y 2727 en la Provincia de Oriente. (Behavior in regard to the mosaic disease of the sugar cane varieties POJ-2714, 2725, and 2727 in the Province of Oriente.) Suplemento de la Memoria de la Segunda Conferencia Anual Asociación de Técnicos Azucareros de Cuba. Dec. 1928, p. 35-62, 1928. (Planters \& Sugar Manuf. 81(6) : 101-104, 1928.)

The calculation of mosaic infection in highly resistant canes. Int. Sugar Journ. (Abstract) 35(419) : 428, 1933.

Paper presented at the Sixth Annual Conference of the Association of Sugar-Cane Technologists of Cuba, held in December, 1932. The author grouped the varieties according to the behaviour of the disease on each, thus P.O.J. 2725 and Java-Barbados Hybrids derived from it in one group and B.H.-10(12), S.C.12(4) and Cristalina in another. He establishes the stalk unit as measurement in calculating mosaic infection against the stool unit, which he declares is misleading in determining the relative commereial immunity. He gave a table comparing the results of both unit basis. He states that incidentally, it may be noted that many of the crosses of P.O.J. 2725 and S.C.12(4) are more resistant than the female parent in spite of the fact that the male parent is very susceptible. Further, the two varieties M 28 and F.C.916 show a relatively high susceptibility in contrast with a practieal immunity recorded in Puerto Rico. 
IMenezes Sobrinho, A.

O mosaico da canna. (The mosaic of cane.) Bol. Agric. Bahia (Brasil) 1926: 25-28, 1926.

Merrick, $\mathbf{F}$.

Coconut bud rot. Cuba Review, 6: 24, 1908.

A popular account.

\section{Miles, L[ee] E[llis]}

Some diseases of economic plants in Puerto Rico. Phytopathology $7(5)$ : 345-351, 1917.

Some new Porto Rican fungi. Trans. Illinois Acad. Sci. 10: 249255, 1917.

Molfino, José $F$.

Novedades micológicas Argentinas. (Mycological novelties in Argentine.) An. Soc. Cien. Argentina 108: 132-138, 341-344, 1929. $109(2): 127-131,1930$.

Nota sobre Mycocitrus aurantium Möll. curiosa especie de Ascomiceta de la Selva de Misiones. (Note on Mycocitrus aurantium Möll. a curious species of Ascomycetes from Selva de Misiones.) Anales Soc. Cient. Argentina 107(3) : 137-143, 1930. Description of that fungi giving locality.

Moler, Alfred

Brasilische pilzblumen von Alfred Möller, Jena. G. Fischer. 1895. (Bot. Mitt. aus den Tropen p. 152, 1895. (Bull. Torr. Bot. Club. 22: 235-238, 1895.)

Protobasidiomyceten. Jena, 179 p., 1895. (Bot. Mitt. aus den Tropen V. 8.)

Phycomyceten und Ascomyceten. Unterchungen aus Brasilien von Alfred Möller, Jena, G. Fisher, 1901.

Montagne, Camille

Prodomus florae Fernandesianse pars prima, sistens enumerationen plantarum cellularium guas in Insula Juan Fernández a C. Bertero collectas descubi, edique curavit. Ann. Sci. Nat. II 3: 347-356, 4:86-99, 1835.

Centurie de plantes cellulaire exotique nouvelles. Ann. Sci. Nat. II. 8: 345-370, 1837.

Cryptogamae guianenses. In his 2 centurie des plantes. Ann. Sei. Nat. II. Bot. 13 : 196-207, 339-359, 1841; 16:108-126, 1841. 
Histoirie Physique, Politique et Naturalle de l' Isle de Cuba. Bot. Plantes Cellulaires,-Cryptogames de Cuba-Paris, 18381842.

Criptogamia. In $R$. de la Sagra, Historia Física Política y Natural de la Isla de Cuba. (Cryptogams. In. R. de la Sagra. Physico-Political and Natural History of The Island of Cuba.) $9: 219,1845$.

Flora chilena, Plantas celulares. In Gray, C. Historia física y política de Chile. Botánica Vols. 7-8, 1850-1852.

Cryptogamia Guayanensis sen Plantarum Cellularium in Guayana Gallica Annis 1835-1849 a Cl. Leprieur Collectarum Enumeratio Universalis Ann. Sci. Nat. ser. 4, 3:135, 1855.

Quelques champignons de la Guinée francaise. Bull. Soc. Mycol. France. 28:31-37, 1912.

Montealegre, Mrariano $\mathbf{R}$.

Enfermedades del café. (Coffee diseases.) Bol. Cam. Agric. Costa Rica 2(5) : 193-201, 1922.

Brief notes on the most common diseases of coffee.

Moore, J. C.

Weed connected with insect and fungous pests and their control. St. Lucía Dept. Agric. Rpt. 1911-12:9-11, 1912.

Plant pests and diseases in Grenada. Imp. Dept. Agric. West Indies. Dept. Agric. Grenada, Ann. Rpt. 1914-15:7, 9, 15, 1915.

IVonet, IN.

(Three enemies of the cacao in St. Thomas.) Journ. Agric. Trop. 7(70): 106-109, 1907.

Morris, D.

Fungous diseases of cacao. Jamaica Dept. Agric. Bull. Dept. Bot. n. s. 8(8) : 113-124, 1901.

\section{Morstati, H[ermann]}

Bibliographic der Pflanzeschutzliteratur das Jahr 1934. Arb. Biol. Reichsanst Land. u. Forstw. Berlin, 302 p., 1935.

This bibliography of German and foreign Literature contains many items of interest.

Müller, Albert S.

Brazil: Preliminary list of diseases of plants in the State of Minas Geraes. Internt. Bull. Plant Protect. 8(9): 193-198, 1934.

As the title implies it is a list of plant diseases most of which are economic crops. 
\& Chupp, Charles

Cercosporae de Minas Geraes (Cercosporae from Minas Geraes)

(Brazil) Arq. Inst. Biol. Veg. 1(3) :213-220, 1935.

Taxonomic.

Doencas do feijao en Minas Geraes. (Kidney bean diseases in Minas Geraes.) Bol. Agric. Zootech. Vet. Minas Geraes (Brasil) 7:384-388, 1934. (Hort. (Abstract) 5(2) : 89-90, 1935.)

Brief account of diseases of beans (Phaseolus vulgaris) in Minas Geraes, (Brazil). Notes on varietal resistance.

Brazil: Some new diseases observed in the State of Minas Geraes in 1934. Int. Bull. Plant. Prot. 9(8) : 175-176, 1935.

The new plyytopathologieal records during 1934, in Minas Geraes (Brazil) are: Colletotrichum glocosporioides on Averhoa carambola; Corticium Koleroga on Coffea arabica; Cercospora citrullina on melon and Rhizoctonia (Corticium) solani on tomato.

Brazil: Some new records of plant diseases in the State of Minas Geraes. Int. Bull. Plant Protect. 10(5) : 98-99, 1936.

Brief notes are given of 27 new phytopathological records from Brazil.

\section{Murray, P[ercival] W[aterhouse]}

Sugar-cane diseases, Jamaica. Jamaica Dept. Agric. Ann. Rpt. $1920: 13-14,1920$.

Agricultural experiments. (Sugar-Cane mosaic, disease.) Jamaica Dept. Agric. Ann. Rpt. 1923 : 12-14, 1924. (Rev. Appl. Mycol. 4: 65, 1924.)

Field experiment in the control of mosaic disease of Jamaica, 1923-25. Jamaica Dept. Agric. Circ. 6:16-37, 1926.

\section{Murrill, William Alphonse}

Polyporaceae. North Amer. Flora. 9:1-72, 73-131, 1907.

Collecting fungi in Jamaica. Jour. New York Bot. Gard. 10 (110) : 21-39, 1909.

The author says: "Mr. Henslow pointed out trees 10 years of age that had been sprayed with Bordeaux Mixture for the bacterial disease of the bud which has wrought such havoc with the cocoanut in Cuba, the Bahamas, and elsewhere." Johnston says: "Mr. Murrill's statement as to the occurrence of the bud-rot in the Bahamas can not be verified.

Collecting fungi in southern México. Journ. New York Bot. Gard. 11(123) : 57-77, 1910. 
408 THE JOURNAL OF AGRICULTURE OF THE UNIVERSITY OF P. R.

The Polyporaceae of Jamaica. Mycologia 2(4) : 183-197, 1910.

A new Boletus from México. Mycologia 2(5) : 248, 1910.

A new Boletus from Jamaica. Mycologia 2(6) : 305, 1910.

The Polyporaceae of México. Bull. New York Bot. Gard. 8(28): 137-153, 1912.

New combinations for tropical agaries. Mycologia 4(6) :331$332,1912$.

The Agaricaceae of tropical North America I. Mycologia 3(1): 23-36, (2) : 79-91, (4) : 189-199, (6) : 271-282, 1911. 4(2) : $72-83,1912 ; 5(1): 18-36,1913$.

Tropical Polypores. New York 114 p., 1915.

Agaricaceae. North Amer. Flora. 9:201-296, 1915. 9:297$374,1916$.

A new phalloid genus. Mycologia 2(1) : 25-26, 1916.

Trinidad, Protophallus jamaicensis Murr.

The Agaricaceae of tropical North Americana. VIII. Mycologia $10(1): 15-33,(2): 62-85,1918$.

The Agaricaceae of tropical North America. VII. Mycologia $10(2): 62-85,1918$.

Cuban Polypores and Agaries. Mycologia 11(1):22-32, 1919.

Bahama fungi. Mycologia 11(4) :222-223, 1919.

Fungi from Ecuador. Mycologia 11(4): 224, 1919.

Quer fungous growth. Mycologia 11(4) : 225-226, 1919.

Antobasidomycetes. In Britton, N. L., The Bahama Flora p. 637-645, 1920.

A new Bolete from Puerto Rico. Gyroporus Earlei sp. nov. Mycologia 13(1) : 60-61, 1921.

Two species of Fuscoporia. Mycologia 13(2): 119, 1921. From Cuba.

The genus Tinctoporia. Mycologia 13(2):122-123, 1921. Mexico and Brazil. 
Light-colored resupinate-Polypores-III. Mycologia 13(2) : 83100, 1921.

Light-colored resupinate polypores IV. Mycologia 13(3):171178, 1921.

Venezuela, Puerto Rico.

\section{IMyers, J[ohn] G[olding]}

Dry-season studies of cane Homoptera at Soledad, Cuba. Contrib. Harvard Inst. Trop. Biol \& Med. 3:69-110, 1926. (Rev. Appl. Ent. ser. A. 14: 497-498, 1926.)

It refers to mosaic disease of sugar cane and corn; its transmission and spread.

Source of witch-broom infection believed to be wild cacao in Suriname. West Indian Com. Circ. 45(618) : 43-44, 1930.

Observations on a journey from the mouth of the Amazon to Mt. Roraima and down to cattle-trail to Georgetown. Agric. Journ. Brit. Guiana 5(2) : 86-100, 1934.

In that trip it was observed that cacao was heavily infected with witches' broom, caused by the fungus Marasmius perniciosus, which apparently has not been reported from the Amazon region before.

Observations on wild cacao and wild bananas in British Guiana. Trop. Agric. (Trinidad) 11(10) : 263-267, 1934.

In this account of his journey in the Amazon Basin in 1932 the author states that the complete absence of witches' broom disease (Marasmius perniciosus) in the wild cacao he saw in the Kanuku mountains was in marked contrast to the badly diseased condition of the wild eacao he had previously observed in the Coppename river, in the interior of Dutch Guiana, with which the Kanuku cacao is obviously identical. Seedlings of the Coppename plants are now growing at the College grounds and at Kew and are of the type which Pittier and others consider to be distinct species (Theobroma leicarpa). Notes are also given on wild bananas and plantains which the author found during his journey, including a reference to Sir Robert Schomburgk's statement that during his travels (1835-39) in Guiana he observed on the coast of British Guiana a peculiar disease in Musa plantations, which starts from the innermost vascular bundles which take a brownish color intermixed with a number of black spots. This is believed to be probably the first reference to Panama disease (Fusarium oxysporum cubense) or something very similar. (e. g. bacterial wilt-Bacterium solanacearum.)

Navarro, A.

Enfermedades de la papa en México. (Potato diseases in México.) Agricultura (México) 1(5) : 335-338, 1934. 


\section{Neger, Franz Wilhelm}

Uredinae et Ustilagineae Fueginae a P. Dusén collectae ofvers K. Svenska Vetenak. Akad. Forhandl. 56:745-750, 1899.

Negretti, A. N.

Tratamientos contra las enfermedades del cacao. (Treatment of cacao diseases.) Rev. Agric. República Dominicana 17 (12) : 188-192, 1923.

A report on a root disease due to Rosellinia pepo. Popular discussion giving symptoms, description of the disease and control.

\section{Nieves, Raimundo}

Contribución al conocimiento de la "caries" del trigo (Tilletia spp.). Contribution to the knowledge of the smuts of wheat. Tilletia spp.) Argentina Bol. Minis. Agric. 29(1):97-110, 1930.

Discussion on the biological characters, genetic behavior and bases for the creation of new resistant varieties.

Ensayos comparativos de resistencia a la Tilletia laevis (Kühn) con Trigos Argentinos e importados, comunes y de "pedigree". (Comparative trials of resistance to Tilletia laevis (Kühn) with common and pedigree Argentine and imported wheats.) Bol. Min. Agric. Nac. (Buenos Aires), 29(3) : 297-316, 1930.

A study of varietal resistance to the fungus Tilletia leavis.

Resistencia comparativa a la Tilletia levis Kühn, del Trigo en la Argentina. (Comparative resistance of wheat to Tilletia levis (Kühn) in the Argentine.) Phytopathology 21(7): 705-727, 1931.

Experimental studies.

Las caries o carbón hediondo del trigo. (Caries or foul smut of wheat.) Bol. Mens. Min. Agric. Argentina. 32:397-411, 1933.

Estudios sobre la especialización fisiológica de las caries del trigo. (Tilletia tritici y Tilletia levis) Argentina. (Studies on the physiological specialization of the smut of wheat in the Argentine.) Guatraché Expt. Sta. Ann. Rpt. 1932:1-108. 1933.

\section{Barraza, José A., \& Horovitz, Noe}

Estudios sobre la distribución y prevalencia relativa de la Tilletia tritici y T. levis, en el sudeste de La Pampa, en 1932. (Studies on the distribution and relative prevalence of Tilletia tritici and T. levis in the South east of La Pampa, in 1932.) Bol. Mens. Min. Agric. Argentina 35 (1-3): 79-101, 1933.

A detailed report of the writers' studies on the bunt disease of wheat. Tabulations are given on the distribution and prevalence of Tilletia tritici and T. laevis. 
Nota preliminar sobre un probable híbrido natural. (Avena byantina $\times$ A. fatua) atacada por Ustilago levis. (Preliminary note on a probable natural hybrid (Avena byzantina $\mathrm{x}$ A. fatua) attacked by Ustilago levis.) Argentine, Bol. Mins. Agric. 36(1) : 71-79, 1934.

Diseussion and account on the subject, giving his observations.

Infección experimental del centeno de Pet Kus (Socale cereale v. vulgare) por las caries del trigo Tilletia tritici (Bjerk.) Wint y Tilletia lovis Kühn. (Experimental infection of Pet kus rye (Secale coreale var. vulgare) by the smut of wheat Tilletia tritici. (Bjerk.) Wint. \& T. levis Kühn.) Argentina, Bol. Mins. Agric. 36(4) : 347-359, 1934.

Experimental record.

Infección experimental del centeno de Petlius (Secale cereale v. vulgare), por las caries del trigo: Tilletia tritici and Tilletia levis. (Experimental infection of rye var. Petkus (Secale coreale var. vulgare) by wheat bunt Tilletia trition and $T$. lovis.) Phytopathology 25(5): 503-515, 1935.

Report of experimental results obtained in artificial infection of rye with wheat bunt disease. (Tillotia tritici and T. laevis.)

Genética de la resistencia a la "carie" (Tilletia tritici raza. 5 M. A.), en la cruza Barleta $x$ Florence (Cheg 27-10x) (Geneties of resistance to bunt (Tilletia tritici strain 5 M. A.) in the cross Barletta $x$ Florence (Cheg 7-10x). Physis, Buenos Aires, 12(4): 51-63, 1936.

The author gives a detailed study on the hereditary nature of the character for resistance to bunt of eertain wheat crosses.

Distribución y prevalencia relativa de la Tilletia tritici y Tilletia levis (caries del trigo) en la región de Guatraché. (The distribution and relative prevalence of Tilletia tritici and $T$. levis (wheat bunt) in the Guatrachá district.) Physis, Buenos Aires, 12(41): 64-70, 1936.

The anthor gives data on distribution, relative prevalence and economic importance of bunt of wheat in the wheat growing centers of La Pampa, Argentine.

\section{Nolla, J[osé] A[ntonio] B[ernabé]}

The anthracnoses of citrus fruits, mango and avocado. Journ. Dept. Agric. Puerto Rico, 10(2): 25-63, 1926.

The results of studies on Colletotrichum gloeosporium and Glocosporium limetticolum. 
Onion-leaf anthracnose. Journ. Dept. Agric. Puerto Rico. 10 $(3-4)$ : 245-256, 1926.

Discussion of a severe outbreak of a fungus on Allium cepa. He deseribed the organism under the name of Colletotrichum chardonianum.

Mango wither-tip. Journ. Dept. Agric. Puerto Rico. 10(3-4) : 257-258, 1926.

A new disease which is caused by Colletotrichum gloeosporioides.

A new Altenaria disease of onion (Allium cepa L.) Phytopathology $17(2): 115-132,1927$.

A description of the disease and methods of control.

The black-shank of tobacco in Puerto Rico. Journ. Dept. Agric. Puerto Rico 12(4) : 185-215, 1928.

A description of the disease which is caused by Phytophthora nicotianae and recommendation for its control.

The eggplant blight and fruit rot in Puerto Rico. Journ. Dept. Agric. Puerto Rico 13(2): 35-57, 1929.

This disease is caused by Phomopsis vexans. The author deseribes the disease and the fungus and gives recommendations for its control.

Biologic control of the aphids Rhopalosiphum persicae Sulzer and Aphis gossypii Glover. Phytopathology (Abstract) 19(1): 102, 1929.

El Acrostalagmus Aphidum Oud. en la lucha contra los áfidos. (Acrostalagmus Aphidum Oud. and Aphid control.) Mem. Real Soc. Española Hist. Nat. 15: 9-12, 1929. (Journ. Dept. Agric. Puerto Rico 13(2): 59-72, 1929.)

Studies on the bacterial wilt of the Solanaceae in Puerto Rico. Journ. Dept. Agric. Puerto Rico. 15(3) : 287-308, 1931.

A very complete study of this disease which is caused by Bacterium solanacearum.

Las enfermedades del tabaco en Puerto Rico. (Tobaceo diseases in Puerto Rico.) Ins. Expt. Sta. Puerto Rico Bull. 39, 29 p., 1932.

Popular account of the disease of most prevalence in Puerto Rico attacking tobaceo. Most of them of fungus origin.

The damping-off of tobacco and its control in Puerto Rico. Journ. Dept. Agric. Puerto Rico 16(2) : 203-204, 1932. 


\section{\& Roque, Arturo}

A variety of tobacco resistant to ordinary tobacco mosaic. Journ. Dept. Agric. Porto Rico 17(4) : 301-303, 1933.

A preliminary report. The variety was introduced from Colombia, Valle del Cauca, in 1929, by the senior author.

Studies on disease resistance. I. A tobacco resistant to ordinary tobacco mosaic. Journ. Agric. Univ. Puerto Rico 19 (1) : 29-49, 1935.

A more detailed and thorough work than the preceding paper. The purpose of this paper is to present the results and observations on infection studies with the Ambalema variety of tobacco.

\section{Nowell, W[illiam]}

Report on a visit to St. Lucía . Agric. News 13(310) : 94-95, 1924.

Fungoid and bacterial diseases. West. Indian Bull. 14(4) : 209216, 1914.

A list of diseases and geographical distribution.

The physiological affections of sea island cotton in the West Indies. West Indian Bull. 14(4) : 304-317, 1914.

A discussion on curly-leaf and loggerhead.

Black root disease of limes. Agric. News 13(327) : 364-365, 1914.

Observations made during a visit to Grenada, Feb.-March 1915. Report issued by the Colonial Secretary, Grenada, 1915.

Diseases of lime trees in forest districts. Imp. Dept. Agric. West Indies. Pamphlet 79, 41 p., 1915.

New light of the witch-broom disease of cacao. Agric. News 14(352) : 382, 1915.

A history on the work on this disease and the results of recent work by G. Stahel, (Bull. 33) September 1915, in which he attributes the disease to a new species, Marasmins perniciosus.

Fungoid and bacterial diseases. West Indian Bull. 15(2) : 133143, 1915.

A list of diseases with distribution.

A stem disease of sugar cane in Barbados. Agric. New. 15(357) : 14, 1916.

Brief popular note. 
414 THE JOURNAL OF AGRICULTURE OF THE UNIVERSITY OF P. R.

The internal disease of cotton bolls. Agric. News 15(364):126127, 1916.

The author refers to an article in West Indian Bulletin, 14: 222-238 and then to specimens collected in Tortola, St. Kitts, Monserrat, St. Vincent and Barbados and to foreign literature.

A new fungous on the green scale. Agric. News 15(375) : 302, 1916.

A record of an undeseribed fungus from Monserrat on Coccus viridis (Lecanium viride). It was sent to Thaxter who said it was closely related to Empusa Fresenii Nowak. He had received the same from Cuba. Johnston reported $E$. Fresenii on mealy bugs in Porto Rico (Bull. 10, Ins. Expt. Sta.)

Pink disease in the West Indies. Agric. News 15(371):238239, 1916.

The author states that the material was determined by Rorer as Corticium salmonicolor. (Bull. Dept. Agric. Trinidad \& Tobago $15(3)$.)

The small Rosellina on cacao. Agric. News. 15(382): 414, 1916.

This note refers to West Indian Bulletin v. 16, No. 1. The author of that paper referred to an unidentified species of Rosellinia on cacao in Grenada and St. Vincent and on immortel in St. Lueia. A later report from Kew Botanic Garden says that this species has a very close resemblance to $R$. paraguayensis Starb. which was described from Paraguay in 1904.

Fungous and bacterial diseases. West Indian Bull. 16(1) :1725, 28-35, 1917.

A list of diseases with distribution.

Rosellinia root diseases in the Lesser Antilles. West. Indian Bull. 16(1) : 31-71, 1917.

Detailed account on Rosellinia Pepo Pat. and $R$. bunodes (B. \& Br.) Sace. Gives description, symptoms, distribution and control measures.

The fungi of internal-boll disease. West Indian Bull. 16(3): 152-159, 203-235, 1917.

A discussion of this disease which the author attributes to Eremothecium cymbalariae Borzi.

The rind fungus of sugar cane. Agric. News 16(387): 62, 1917.

This is a diseussion of Johnston's paper in Vol. I, No. 1, of the Journal of the Board of Commissioners of Agriculture of Puerto Rico (Later Journ. Dept. Agric. of Puerto Rico and now Journ. 
Agric. Univ. Puerto Rico.) It contains some historical data and the writer's opinion of this direase.

New records of entomogenous fungi in Barbados. Agrie. News 16(388): 94, 1917.

The writer found Perticitlizm hetorocladum on a species of eitrus white fly; Aschersonia (cubensis?) on star seale (Vinsonia) and Ophioncetria coccicola on purple seale (Lepidosaphes). All on leaves of lime trees in a deep gulley. The first las been reported in Puerto Rieo, the third is common and useful in Dominica and St. Lucia and occurs in Grenada and St. Vineent.

Diseases of economic plants. West Indian Bull. 16(4):309310, 322-331, 1917.

A useful list.

The status and treatment of coconut bud rot. Agric. News 16 (ن85) : $30,1917$.

This note states that the disease destroyed a grove in Matanzas, Cuba, previous to 1886 . It appeared in Baracoa as early as 1880 . Heavy losses in Jamaiea in 1891-1910, in Cayman Islands in 1891. Unconfirmed records from Santo Domingo and Haiti. Appears to be absent from Florida, Ballamas and Puerto Rico. Reports indicate that it is present in British and Spanish Honduras. Johnston reported that it was not present in Panama. In Trinidad in 1907. Small outbreaks in Grenada, St. Vincent and St. Lucia. Common in British Guiana and reported from Surinam.

Sugutr-cane diseases in Puerto Rico. Agrie. News 16(393):158, 1917.

A comment to the Fifth Amnual Report (1916) of the Insular Experiment Station of Puerto Rico, written by John A. Sterenson.

Bacterial diseases of tomatoes in St. Vicent. Agric. News 16 (409) : 414-415, 1917.

A report ou wit caused by Bacterium solanacearum $\mathrm{E}$. F. S.

Algal diseases (red rust) of cacao. Agric. News 17(421): 190, 1918.

This disense is due to Cophaleuros vireseens Kunze (C. mycoidea Karst, Myeoidea parasitica Cunn.) Reported in St. Lucia in 1917. Previously reported in Trinidad by Rorer (Proc. Agri. Soc. Trinidad \& Tobago v. 17.) Reported from Grenada in 1902. Known in St. Lucia and Dominiea.

Diseases of coconuts in Jamaica. Agric. News 17(427) :286-287, 1918.

This refers to two leaflets by Ashby. They diseuss bud rot. The fungi involved are Thielaviopsis paradoxa and Phytophthora sp. The 
forms are: (1) pineapple or leaf-bitten disease, (2) hard or little leaf-bitten disease, (3) Phytophthora leaf-bitten disease, and (4) Rhinoceros beetle leaf-bitten disease.

The ring or root disease of coconut palms. West Indian Bull. $17(4): 189-202,1918$.

A history and symptoms of the diseases, the causal organism (nematode) and methods of control.

Root disease of coconut palms in Grenada. Agric. News 17(434): 398-399, 414, 1918.

This note describes the symptoms but does not name an organism. The symptoms agree with those described by Stockdale for Trinidad and Tobago in 1906 and later by Rorer.

Fomes lucidus as a parasite of trees. Agric. News 17(412): 46, 1918.

The author reports this fungus as attacking the Saman trees (Pithecolobium Saman) and the bread and cheese tree ( $P$. unguiscati) in the Botanic Garden of St. Kitts in 1914. He states that it is reported from Curacao as attacking Caesalpinia coriaria and Acacia tortuosa and in South Africa on Acacia spp. and Acacia mollissima. It has been reported previously on lime trees in Monserrat. (See West Indian Bull. 7: 493.)

Diseases of economic plants. West Indian Bull. 17(2):96106, 1918.

A list of diseases with geographical distribution.

Eel-worm disease (Black head) of bananas. Agric. News 17 $(422): 206,1918$.

Reported from Grenada on the coarse banana known as bluggoe. The disease is described. A similar disease has been reported from Jamaica by Ashby (Bull. Dept. Agric. Jamaica 2:116) and attributed to Tylenchus similis.

Report on an investigation of froghopper pest and diseases of sugar cane in Trinidad. Bull. Dept. Agric. Trinidad \& Tobago 18(2) : 57-69, 1919. (Trinidad \& Tobago Council Paper No. 39, 1919.)

This paper contains brief reference to Marasmius sacchari, Himantia stellifera, Odontia sacchari and $O$. saccharicola. Also factors influencing root disease.

The red ring or root disease of coconut palms. West Indian Bull. 17(4) : 189-202, 1919.

A discussion of the history, symptoms and cause of this disease. 
The red-ring disease of coconuts. Proc. Agric. Soc. Trinidad \& Tobago. 19(9-10):217-219, 1919. (Agric. Soc. Trinidad \& Tobago Soc. paper $736,1919$.

A brief report on this disease which is caused by nematodes.

Foot rot or mal di gomma on limes. Agric. News 18(439):62, 1919.

This note refers to this disease on the island of Grenada, but does not explain cause.

A root disease of cacao in Trinidad, Rosellinia pepo. Trinidad \& Tobago Dept. Agric. Bull. 18(4): 178-199, 1919.

A description of the disease, method of infection and control measures.

Disease of sugar cane. Agric. News. 16(384): 14, 1917.

The red-ring disease of coconut palms. West Indian Bull. 18 (1) : 73-76, 1920. (Trop. Agric. (Ceylon) 54(4) : 240-245, 1920.)

A continuation of previous work mentioned above. (West Indian Bull. v. 17(4).)

Mosaic disease of sugar cane. Agric. News. 19(462) : 14, 1920.

A review of the U. S. Dept. Agric. Bull. 829 by Brandes and Bull. 19 of the Insular Experiment Station of Puerto Rico by F. S. Earle.

Notes on the proclaimed diseases and pests. Bull. Dept. Agric. Trinidad \& Tobago 19(4) : 175-179, 1920.

Brief discussion of coconut bud rot, red ring of coconut, mosaic of sugar cane and anthraenose of lime.

Red-ring disease of coco-nuts. Agric. News 19(475): 222, 1920. Recommendations for the disposition of infected material.

Root disease of cacao. Journ. Jamaica Agric. Soc. 24(6-7) : 173174, 1920.

A partial reprint from Bull. Dept. Agric. (Trinidad \& Tobago) 18, 1920.

A disease of coco-nut. Imp. Dept. Agric. West Indies Rept. Agric. Dept. (St. Lucía) 1918-19: 7, 1920.

Material received in bad condition but the organism was probably Pythium or a Phytophthora. 
\& Williams C. B.

Sugar cane blight in Trinidad. Bull. Dept. Agric. Trinidad \& Tobago. 19(1):8-10, 1920.

These diseases are caused by Marasmius and Odontia.

A supposed nematodes disease of banana. West Indian Bull. $17(3): 177-179,1919$.

A brief discussion.

Infection of orange fruit through bug punctures. Agric. News $17(418): 142,1918$.

Believed to be due to fungous infections of puctures by insects.

Internal disease of cotton bolls in the West Indies, II. West Indian Bull. 17(1): 1-26, 1918.

The organism is Nematospora sp.

Mycologist's report on a visit to Trinidad. Proc. Agric. Soc. Trinidad 19(6): 141-159, 1919.

A discussion of root diseases of sugar cane in relation to injury caused by frog-hopper. Remedial measures are suggested.

Bracket fungi of lime trees and the critical period in the development of young lime trees. Rept. on the Agric. Dept. (Dominica) 1917-18:11-14, 1919.

A report on the small fungi Nectria and Stilbum are most prominent on dead branches of lime trees.

Investigation of the frog-hopper pest and disease of sugar cane. Agric. News 18(446):174-175, (447):190-191, (448):207, (449) : 222-223, 1919.

A description of the disease supposed to be caused by the froghopper (Tomaspis saccharina). This is doubted and the author believes that it is due to Marasmius and Odontia.

Red ring disease of coconuts. Agric. News 18(460) : 398, 1919. The disease is caused by nematodes.

The cacao canker fungus as a cause of coconut but rot. Agric. News (Barbados) 18(461): 414, 1919.

Discusses Reinking's work on Phytophthora faberi on coconuts in the Philippine Islands and Ashby's studies on P. palmivora on coconuts in the West Indies.

Rosellinia pepo an Ascomycete injurious to cacao in Trinidad, West Indies. Rev. Sci. \& Pract. Agric. 11(7) : 923-925, 1920. 
Eradication of mosaic clisease in Trinidad. Bull. Dept. Agric. Trinidad \& Tobago 19(3) : 105-106, 1921.

Disease of erop plants in the Lesser Antilles. 325 p., 1923.

This book contains much data on diseases.

\& Ulrich, . W.

Notes on the proclaimed diseases and pests. Bull. Dept. Agric. Trinidad \& Tobago. 19(4): 175-181, 1922. A

A diseussion of bud rot of coconut, Gloeosporizm limetticolum and of semi-parasitic flowering plants.

Diseases of cacao in Trinidad. Soc. Paper 775. Proc. Agric. Soc. Trinidad \& Tobago. 22(5):483-493, 1922.

Popular discussion of die-back, Diplodia pod rot, algal disease, thread bliglit, Rosellinia root disease and black pod rot and eanker (Phytophthora fabari).

Disposal of black pods and eacao luasks. Empire Prod. and Export 85, Sept. 1923. (Trop. Agrie. (Ceylon) 61(5) : 295$296,1923$.

This is a recommendation for the control of Phytophthora faberi.

Coconut bud-rot in Trinidad. Rept. Imper. Bot. Conf. Liondon, 1924 : $161-162,1925$.

A brief discussion.

Diseases of coffee. Proc. Soe. Trinidad \& Tobago. 26(7):339$342,1926$.

Diseusses Omphalia flavida, Cercospora coffeicola and Sclerotium coff eicolum.

Nyhus, P. 0.

The potato situation in Argentine. Amer. Potato Journ. 13(7): 185-189, 1936.

Drought, insects and diseases reduced considerably the potato crop in Argentine and Uruguay. Foreign supply was urgent. The most noticeable diseases were those of virus type.

Ogilvie, $:[$ awrence]

Preliminary Report of the Plant Pathologist for the period September 27 to December 31, 1923. Rept. Board \& Dept. of Agric. (Bermuda) 1923: 28-34, 1924.

The possibility of the introduction into Bermuda of the diseases of the banana. Agric. Bull. (Bermuda) Dept. Agric. $3(2): 7-8,1924$.

The author believes that there is very little danger. Musa cavendishii the species most commonly grown in Bermuda is said to be immune. 
Celery in Bermuda. Agric. Bull. Bermuda Dept. Agric. 3(6): 1-7, 1924.

Includes notes on Cercospora apii.

Report of the Plant Pathologist for the year 1924. Rept. Board \& Dept. of Agric. (Bermuda) 1924: 32-43, 1924.

Peports a Gloeosporium dieback on Persea gratissima, G. musarium on banana, Helminthosporium on corn, Colletotrichum gloeosporioides on citrus, Uncinula necator and Gloeosporium ampelophagum on grape, Sclerotinia libertianum (S. sclerotiorum) on carrots, celery, Vicia sp., Botrytis on Lilium harinissi, Fusarium malli on onions and Peronoplasmopara (Pseudoperonospora cubensis) on cucurbits.

Notes on leaf-roll of potatoes. Agric. Bull. Bermuda Dept. Agric. 3(12) : 1, 1925.

Agenda put forward by Bermuda delegate. Proc. Ninth West Indian Agric. Conf. 1924: 128-133, 1925.

Inspection and certification.

Report of the Plant Pathologist for the year 1925. Rpt. Dept. Agric. (Bermuda) 1925: 36-63, 1926.

Reports several common diseases.

Notes on lilies. Agric. Bull. (Bermuda) Dept. Agric. 6(4). 4-5, 1927.

A report of inspection of Lilium longiflorum var. eximium for mosaic.

The black tip disease of bananas. Agric. Bull. Dept. Agric. (Bermuda) 6(9): 4-5, 1927.

A brief discussion of this disease which is attributed to Cercospora musarum Ashby. Causes a black discoloration beginning at the tip of the fruit. Attacks Musa cavendishii.

Aster yellows in Bermuda. A disease of many cultivated plants. Bermuda Agric. Bull. 6(5) : 7-8, 1927.

An important virus of Lilium longiflorum and its varieties. Nature 119(2997) : 528, 1927.

A report of yellow flat on Lilium longiflorum and its varieties, $L$. giganteum ( $L$. longiflorum var. tapesina), $L$. formosum ( $L$. longiflorum var. insulare) and $L$. hamsii ( $L$. longiflorum var. eximium). Transmitted by Aphis lilit. 
Notes on the growing of Citrus in (Bermuda) Agric. Bull. Bermuda. Dept. of Agric. 6(11) : 3-5, (12):4-5, 1927. 7(2) : 3-6, 1928.

Refers to Colletotrichum gloeosporioides, Sporotrichum citri and false melanose or greasy spot.

Late spraying of celery--Agric. Bull. Dept. Agric. (Bermuda) $7(5): 4,1928$.

The author used Burgundy mixture for the control of Septoria apii.

"Blaek tip", a finger-tip disease of the Chinese banana in Bermuda. Phytopathology 18(6) : 531-538, 1928.

This disease is due to Cercospora musarum.

Report of the Plant Pathologist for the year 1927. Bermuda Dept. Agric. Ann. Rpt. $1927: 26-37,1928$.

Notes on mosaic diseases of banana. Hippeastrum and lettuce and other diseases of crop plants.

, \& Guterman, C. T. F.

A mosaic disease of the Eastern lily. Phytopathology 19(3): 311-315, 1929.

A deseription and studies on insect transmission.

The Bermuda Easter Lily. Roy. Bot. Soc. (London) 39:4-6, 1929.

This paper is based on a study of a disease of Litium longiflorum in Bermuda.

\section{Olive, gagar W[iliam]}

Report of a trip to study and collect rust and other parasitic fungi of Puerto Rico. Brooklyn Bot. Gard. Rec. 5: 117-122, 1916.

\section{\& Whetzel, $\mathrm{H}$ [erbert] $\mathrm{H}$ [ince]}

Endophyllum-1ike rusts of Puerto Rico. Amer. Journ. Bot. 4(1) : 44-52, 1917 .

The cytological structure of Botryorhiza Hippocrateae. Brooklyn Bot. Garden Mem. 1: 337-341, 1918.

\section{Oliver $\mathrm{y}$ Lugo $\mathrm{F}$ [ernando]}

EI mosaico del tabaco y como combatirlo. (Tobaceo mosaic and how to control it.) Rev. Agric. Puerto Rico. 10(1):11-14, 1923.

The author believes that the disease persists in the soil and recommends a three-year crop rotation. 


\section{Otero Braquertt, José}

Unas palabras sobre la enfermedad de la caña "El Matizado" o "rayas amarillas". (A few words about the sugar-cane disease mottling or "yellow stripes" in the Antilles.) Rev. Agr. Com. Trab. Cuba. 7(4).46-54, 1924.

\section{Otero, José I[dilio,] \& Cook, Melville T[hurston]}

Partial bibliography of virus diseases of plants. Journ. Agric.

Univ. Puerto Rico 18(1-2): 1-410, 1934.

This work contains numerous citations on plant pathology and mycological work of the area to cover.

\&

First supplement to partial bibliography of virus diseases of plants. Journ. Agric. Univ. Puerto Rico. 19(2): 129-313, 1935.

First supplement to the above-mentioned work.

$\&$

Second supplement to partial bibliography of virus diseases of plants. Journ. Agric. Univ. Puerto Rico 20(3): 741-818, 1936.

The title implies the character of work.

Pachano, Abelardo

Dos enfermedades de las papas. (Two diseases of potatoes.) Quinta. Normal (Ambato, Ecuador) Estac. Exp. Cire. 7, 11 p., 1918.

A discussion of symptoms and control of Phytophthora infestans and Alternoria solani.

Poige, P. I.

The future of Uba cane in Puerto Rico. Memoire Ass'n Sugar Cane Tech., Puerto Rico. 1(1):25-27, 1922 . (Facts About Sugar. $15(21): 420-421,1922$.

A brief reference to varietal resistance and susceptibility.

La enfermedad del matizado; su extirpación y control. (The mottling disease; its eradication and control.) Rev. Agric. Puerto Rico. 11(1): 19-22, 1923. (Australian Sugar Jomrn.) 15(7):428-429, 1923. Facts About Sugar 17!(1):14-15, 1923.)

Fields have been practically freed from mosaic by roguing.

Palm, B[jorn] T[owald]

A note on Entyloma Dahliae Syd. From Sumatra and Guatemala. Phytopathology 22(7): 868-869, 1932.

On Cyttaria Berk. and Cyttariella n. gen. Ann. Mycol. 30:405$420,1932$. 
Biolgoical notes on Albugo. Ann. Mycol. 30:426, 1932.

Rhodochytrium en Amerique centrale. Rev. Algol. 6:351-353, 1932.

Pflanzenkrankheiten aus Guatemala. (Plant diseases in Guatemala.) Zertschr. fur Pflanzenkrankh. u Pflanzenchutz. 42 (1) : 11-17, 1932 .

An annotated list of plant diseases observed by the author during his stay in Guatemala with exception of virus diseases.

Algae as additional hosts of pathogens to angiosperms (Preliminary note) Zentralbl. Bakt. II. Abt. 87(9-12) : 229-233, 1932.

Demonstrations that Rosellinia necatrix and Pythium mamillatum attack several algae (Vaucheria, Hydrodictyon, Cladophora) in the soil, Giberella saubinetii (Fusarium stage) and Cylindrocarpon mali. Also attack algae.

Eriodendron as host of Bacterium malvacearum. Phytopathology $22(10): 867-868,1932$.

This organism attacks a Mexican variety (pochote) of the kapok tree (E. anfractuosum).

\section{Parodi : $[$ [mundo]}

Sulle cause della decadenza della cultura del cacao all' Ecuador e possibili remedi. (On the cause of the decline of cacao cultivation in Ecuador and possible remedies.) Agron. Colon. $30(4): 121-127,1936$. (Rev. Path. Veg. 26:176, 1936.)

The decline of the cacao industry in Ecuador is due mainly to witehes' broom disease (Marasmius perniciosus) and moniliasis (Monilia Roreri). Control measures are given.

Parodia, Lorenzo $\mathbf{R}$.

Las malezas de los cultivos en el partido de Pergamino. Buenos Aires p. 75-171, 1926.

Patouillard, Narcisse, \& Lagerheim, G. de

Champignons de l' equateur. (Fungi of Ecuador.) Bull. Soc. Mycol. France 4: 101-106, 1888.

\section{\& Gaillard, A.}

Champignous du Vénézuéla et, Principalement de la region du Haute-Orinoque, recoltés en 1887 par. M. A. Gaillard. (Fungi of Venezuela and especially those of Upper Orinoco region collected in 1887 by Mr. A. Gaillard.) Soc. Mycol. France 4 : 101-106; 6: 7-46; 92-129, 1888.

Taxonomic, includes 278 species. 
424 THE JOURNAL OF AGRICULTURE OF THE UNIVERSITY OF P. $R$.

Quelques espéces nouvelles de champignons extraemopéens. Rev. Mycol. 13: 135-158, 1891.

Taxonomic; records Polyporus savoyamus, $P$. multiceps and P. turbinatus as new species from Venezuela.

Contribution a l'etude des champinons extra-européens. Bull. Soc. Myc. France 3:119-131, 1887.

Taxonomic records Phyllachora sphaerospora Pat. as new species from Venezuela.

Liste de Champignons récoltés en Basse-Californie par M. Diguet. (List of fungi collected in Lower California by $\mathrm{Mr}$. Diguet.) Journ. de Bot. 10:250-252, 1896.

Quelques champignos noveaux récoltés au Mexique par Paul Mauri. (Some new fungi collected in México by Paul Mauri.) Bull. Soc. Mycol. France 14:53-57, 1898.

Champignons nouveaux ou peu commus. (New or little known fungi.) Bull. Soc. Mycol. France 14: 149-156, 1898.

Deseriptions de quelques champignons extra-européens. Bull. Soc. Mycol. France 18: 299-304, 1902.

Basidomycetes nouveaux du Brésil recucilles par F. Noack. (New Basidomycetes from Brazil collected by F. Noack.) Ann. Mycol. 5: 364-366, 1907.

The root rot of coffee in Guadeloupe. Journ. Agr. Trop. 10 (104) : 58-59, 1910.

Brief notes describing a coffee root disease caused by a fungus which probably is a Roseliinia or a Dematophora. Methods of con. trol are given.

Quélques champignons du Costa Rica. (Some fungi from Costa Rica.) Bull. Soc. Mycol. France 28:140-143, 1912.

Quelques champignons de Vénézuela (Some fungi from Venezuela.) Bull. Soc. Mycol France 42:289-294, 1927. Taxonomic, records. 
\& Heim $\mathbf{R}$.

Champignons recueillis, par M. Myeul Grisol dans le HautOrenoque. (Fungi collected by M. Myenl Grisol in the Upper Orinoco.) Ann. du Cryptog. Exotique 1:266-278, 1928.

Taxonomic; records Laschia lactea, Lentinus microloma and Crinipellis rubidus as new species from Venezuela.

Pazschke, F. 0 .

Rabenhorst-Winter. Fungi Europaei Cent. 38, Cura Dr. 0. Pazensehke. Hedwigia 30:197-209, 1891.

Erstes verzeichniss der $\mathrm{E}$. Ule in den Jahren 1883-1887 in Brasilien gesammelten pilze. Hedwigia 31:93-114, 1892.

Zweites verzeichniss brasilianischer ron E. Ule gesammelter pilze. Nach Untersuchungen von G. Bresadola, P. Hennings, H. Rehm und Nach eigénen beobachtungen zusammengeatellt von O. Pazschke. Hedwigia 55:50-55, 1896.

Pennington, $\mathbb{N}$. S.

Uredineas recolectadas en las islas del delta del Paraná. (Uredineaceae collected in the delta of the Paraná.) Anal. Soc. Cient. Argentina 53:263-270, 1902; 55:31-40, 1903.

Pestico, J. F.

("Fucha" of the cotton plant in the department of Boyaca, Rep. Colombia.) Rev. Agrie. 4: 113-116, 1918.

A description of the disease which is said to be due to lack of good cultural practice.

Petrak, F., \& Ciferri, R[afael]

Fungi Dominicani. Ann. Afycol. 28:377-420, 1930.

Mykologische Notizen VI, VIIT, IX, XI. (Mycological Notes VI, VIII, IX, XI) Ann. Nycol. 22:1-182, 1924; 23:69, 1925; $25: 258,1927 ; 29: 339-397,1931$.

Fungi dominicani II. Ann. Mycol. 30:149-353, 1932.

\section{Philippi, Federico}

Der pilze: Chiles, soweit dieselben als nahrungesmittel gebrancht werden. Hedwigia $32: 115-118,1893$.

Picado T., C[lodomiro]

Sur l'action á distance des champignons phytopathogenes. (Action at a distance by pathogenie fungi.) Congres Path. Veg. Strasbourg. p. 28-34, 1923.

Fusariose des cafeir's á Costa Rica. (Fusariosis of coffee in Costa Rica.) Rev. Path. Veg. Ent. Agr. 18(10): 312-318, 1931. 
Fusarium disease of coffee in Costa Rica. Jour. Dept. Agric. Puerto Rico. 16(4): 389-400, 1932.

Diseussion on Fusarium anisophilum and the disease eaused by this fungus in the coffee trees of Costa Rica. He also discusses transmission on other host plants.

Colletrotrichum des cafeiers et lesions radiculaires. (Coffee Colletotrichum and root lesions.) Rev. Path. Veg. \& Ent. Agr. $20(8)$ : 268-270, 1933.

A coffee disease has been described recently from Costa Rica and two organisms were identified, Glomerella cingulata and Fusarium literitium var. majus. Gives experimental evidence to demonstrate that the direct cause of the root disease is the Fusarium and that the Colletotrichum is a parasite of the primary fungus.

Pickel, B.

Alguna parasitos radicolas do cafieiro em Pernambuco. (Some coffee root parasites in Pernambuco.). Characas e Quintaes, S. Paulo, 37:369-370, 1928.

\section{Pittier, H[enri]}

La enfermedad del banano y su causa. La Hacienda 7(11) : 343346, 1912.

Estudio sobre deformaciones, enfermedades y enemigos del árbol de café en Venezuela. (Studies on deformation, diseases and enemies of the coffee tree in Venezuela.) Cam. Com. de Caracas, Bol. 120, 1923.

Degeneration of cacao through natural hybridization. Journ. Hered. 26: 385-390, 1935.

Plank, H. K.

Fungi attacking Diatraea sacharalis Fab. in Cuba. Jour. Econ. Ent. 22: 983-984, 1929.

\section{Plantengen, Marís $\mathrm{H}$. J.}

Pathologische verandenrigen in het phoem. (Pathological disturbances in the phloem.) Tésis. Utrecht. (Holland-Drukkery, Bearn.) 108 p., 1932.

In this rather extensive work the author reports his experimental studies in the transmission and inoculations in regard to the phloem necrosis disease of coffee in Surinam.

Plaxton, Dr.

Journ. of the Institute of Jamaica. 1:43-44, 1891-93, 1893.

Pino, Raphael del

El País Jan. 29, 1886 . Reprinted from Balmaseda's paper in Tesoro del Agricultor Cubano. 2 ed. 2:135, 1893. 
Poumd, ㅍ. J.

Studies of fruitfulnes in cacao. Rep. Cacao Res. (Trinidad) 1935 : 16-19, 1936.

Report on the effect of potash and phosphate on eacao infested with Phytophthora palmivora.

Prescott, S. C.

Diseases of the banana. United Fruit Co. (Boston, Mass.) Bull. 2, 1917.

Priode, C. N.

Observaciones adicionales sobre la enfermedad Pokkah-bong de la caña de azúcar en Cuba (Pokkah-bong disease of sugar cane in Cuba.) Memoria Cong Ann. Asoc. Tech. Azucareros (Cuba). 3: 106-114, (Spanish) : 98-106 (English), 1929.

A description of the symptoms of this disease which is caused by Fusarium sp.

Pokkah-bong and twisted top disease of cane. Facts About Sugar. 23(52) : 1244, 1928.

Popular.

Pokkah-bong and twisted top disease of sugar cane in Cuba. Phytopathology 19(4) : 343-366, 1929. (Reprinted as a Tropical Plant Research Scientic. Con. 14, 25 p., 1929.)

A full account of the disease which is due to Fusarium monitiforme (Giberella moniliformis).

Target blotch of sugar cane. A new Helminthosporium disease.

Facts About Sugar 24(16): 376, 1929.

Popular.

Target blotch of sugar cane. Phytopathology 21(1):41-58, 1931.

A description of a disease which he attributes to Helminthosporium sp.

Notes on the diseases attacking the P.O.J. canes in Cuba. Proc. Ann. Conf. Asoc. Tech. Azuca. (Cuba) 5: 138-144, 1931.

A discussion of eye spot (Helminthosporium ocellum), brown stripe (H. stenospilum), pokkah-bong (Fusarium moniliforme), red stripo (Phytomonas rubrilineans), root diseases and galls.

Cuban streak. Phytopathology 23(8) : 674-676, 1933.

A virus disease of sugar eane. Different from the streak in Africa. 
Two hosts of the pokkah-bong disease other than sugar cane. Phytopathology 23(8): 674-676, 1933.

This disease which has been attributed to Fusarium moniliforme attacks corn and sorghum in Cuba.

\section{Puttemans, $A[$ rsene]}

Sur l'Oidium du Chéne au Brésil. (On the Oidium of Oak in Brazil.) Bull. Soc. Path. Vég. 7:37-40, 1920.

O "mosaico" da cana de assucar. (The mosaic of sugar eane.) Bol. Min. Agric. Ind. o Com. Brazil. 12(2) : 350-355, 1926. (Rev. Appl. Ent. ser. A. 15:67, 1927.)

Uma ferrugem nova en a planta australiana cultivada no Brasil. (Puccinia camargoi) Bull. Mus. Nac. Río de Janeiro, 6:312314, 1930.

Pyke, E. E.

Mycorrhiza in cacao. Rep. Cacao Res., Trinidad 1934:41-48, 1935.

Report of the occurrence of Mycorrhiza in Trinidad. Describes the forms and lesions.

Rada, G. G.

Tres enfermedades del manzano. (Three diseases of the apple.) Esta. Expt. Agric. La Molina (Perú) Circ. 25, 21 p., 1934.

Popular notes giving the symptoms, etiology and control of apple scab (Venturia inaequalis), powdery mildew (Podosphaera leucotricha), and black rot (Physalospora cydoniae or P. malorum.)

Principales enfermedades del algodonero en el Perú. (The principal cotton diseases in Perú.) Est. Expt. Agric. (Perú) Circ. 28, 19 p., 1935.

Popular notes of the most common diseases of cotton in Perú among which are mentioned Fusarium vasinfectum, Rhizoctonia (Corticium) solani, Erysiphe malachrae, Helminthosporium gossypii, Alternaria tenuis. Notes of control and species resistance are given.

Rahm, G.

Nematodes parasitas e semi-parasitas de diversas plantas eulturaes do Brazil. Arch. Inst. Biol. 2 : 67-136, 1929.

\section{Ramírez, Román}

Manifestación rara en una cebolla. (A rare affection of an onion.) Rev. Agric. (México) 2(1) : 34, 1918.

A record of a disease without giving the cause.

Enfermedades del camote. (Diseases of the sweet potato.) Rev. Agric. (México) 2(8) : 344, 1918.

The disease appeared in Lower California and is attributed to Oozonium omniovorum. 
Enfermedad grave de la caña. (Serious disease of cane.) Rev. Agric. (México) 4(7-8): 348-349, 1919.

Reports Thielaviopsis paradoza as cause of losses in yellow Caledonia in Mexico.

Dos parásito de la remolacha. (Two beet parasites.) Rev. Agric (México) 5(2) : 141-142, 1919.

One is due to Septoria sp.

Enfermedad de los árboles de limón. (A Iemon disease.) (México) $5:(3-4): 278-279,1919$.

A leaf spot caused by Cladosporium sp. Macrosporium sp.

Viruela del algodón. (Cotton rust.) Rev. Agric. (México) 5 (6) : 461, 1920.

This disease which is due to Aecidium gossypii is the cause of heavy losses.

Enfermedad en Ios naranjos de Turicato, Michoacan. (An orange disease in Turicato, Michoacan.) Rev. Agric. (Mexico) 5(7): $547,1920$.

An orange rot caused by Penicillium sp. and Aspergillus sp. and other fungi following insect punctures.

Enfermedad de los pinos de Guadalajara. (A pine disease in Guadalajara.) Rev. Agric. (México) 5(9):601, 1920.

A disease of the twigs caused by Schizotrichum sp.

Cyathus de la vid. (A Cyathus on grape.) Rev. Agric. (México) 5(10): 720, 1921.

El chahuixtle rojo del frijol. (Rust of the bean.) Rev. Agric. (México) 5(12) : 830, 1921.

An account of Uromyces appendiculatus on the common bean.

Enfermedad de las dahlias. (A dahlia disease.) Rev. Agric. (México) 6(2): 100, 1921.

Popular account of Oidium disease of dahlia.

\section{Rands, R[obert] D[elafield]}

South American leaf disease of Para rubber. U. S. Dept. Agric. Bull. 1286, 18 p., 1924.

The results of the authors' studies on this disease of Hevea brasiliensis. The disease is caused by Dothidella (Melanopsammopsis) ulei.

Rangel, E[ugenio] dos Santos

Fungos parasitos do guado Cajanus indicus Spreng. (Parasitic fungi of pigeon pea Cajanas indicus Spreg.) A Lavoura 18: $5-12,1916$. 
THE JOURNAL OF AGRICULTURE OF THE UNIVERSITY OF P. R.

Contribuicao para e estudio dos Puccinias das Mytaceas. (Contribution to the study of the Puccinias of the Myrtaceae.) Archiv. Mus. Nac. Río de Janeiro 18:147-156, 1916.

Fungos do Brasil novos ou mal conhecidos. (Fungi from Brazil new or little known.) Arch. Mus. Nac. Río de Janeiro 18: 157-164, 1916.

O combate ao mosaico (Mosaic-disease control.) Bol. Agric. Bahia 1926: 26-34, 1926.

O combate ao mosaico. (Mosaic-disease control.) A Lavoura $30: 203-204,1926$.

Alguns fungos novos do Brasil. (Some new fungi from Brazil.) Arch. Jardin Bot. Río de Janeiro 2:67-71, 1918.

Fungos do Brasil, novas on mal conhecidos. (Fungi of Brazil, new or little known.) Bol. Int. Brasileiro Sciencias. 2(10): $333-335,1926$.

Os inimigos vegetaes do cafeiro. (Coffee vegetable enemies.) Rev. Agr. Sec. Agr. Ind. Com. e Obras Pub. Bahía, 1(12): 125-129, 1927.

Discusses the following fungi and describes the damages caused by each: Hemileia vastatrix, B. \& Br. Omphalia flavida Man. \& Ren., Colletotrichum coff eanum Noak, Cercospora coffeicola Br. \& Curt. Capnodium brasiliense Putt., Cephaleuros virescens Kunze, Corticium javanicum Zimm., Sphaerela coffeicola Cooke.

Raunkiaer, C.

Fungi from the Danish West. Indies collected 1905-1906. Bot. Tidssk 29(1): 1-25, 1908.

Myxomycetes from the West Indian Islands, St. Croix, St. Thomas and St. Jean. Dansk. Bot. Archiv. 5(16) : 1-9, 1928.

Reddick, Donald

Some diseases of wild potatoes in México. Phytopathology 22(1): 609-612, 1932.

Some diseases of wild potatoes in México. Phytopathology (Abstract) 22(1):22, 1932.

Reported Phytophthora infestans on Solanum verrucosum and $\mathrm{Pu}$ cinia pittieriana on $S$. demissum.

Rehm, H.

Exotische Ascomyceten. Hedwigia 28:295-303, 1889.

Taxonomic; includes Corallomyces elegans Berk. \& Curt., from Venezuela. 
Beträge zur Pilzflora von Südamerika III. Dothideaceae. (Contribution to the fungi flora of South America III. Dothideales Hedwigia 36: 366-380, 1897.

Beiträge zur Pilzflora von Sudadmerika. (Contribution to the fungi flora of South América.) Hedwigia 37:321-328, 1898.

Beiträge zur Piezflora von Südamerika XII-XVII. Sphaeriales et al. (Contribution to the fungi flora of South America XII-XVII. Sphaeriales and others.) Hedwigia 40:100-124, 141-144, 145-170, 1901.

Beiträge zur Pilzflora von Südamerika. XIV. (Contribution to the fungi flora of South America.) Hedwigia 44:1-13, 1904.

\section{\& Rick, Johann.}

Noviatates brazilianses. Broteria 5:223-228, 1906.

\section{Reinking, Otto A[ugust]}

Banana freckle and leaf spot. Mycologia 18(4) : 185-186, 1926.

Description of a disease of plantain (Musa paradisiaca) caused by the fungus Macrophoma musae.

Fusaria inoculation experiments. Relationship of various species of Fusaria to wilt and Colorado disease of banana. Phytopathology 16(6) : 371-392, 1926.

The results of extensive studies on Fusarium cubense.

\section{\& Wollenweber, $\mathrm{H} . \mathrm{W}$.}

Tropical Fusaria. Phil. Journ. Science. 32(2) : 103-253, 1927. Descriptions of species found in Honduras and Guatemala.

\section{\& Manns, IM. IM.}

Parasitic and other Fusaria in tropical soils. Zeitschr. für Parasitenkunde. 6(1): 23-75, 1933.

Parasitic and other Fusaria counted in Colombia soils. Zentralbl. für Bakt., Ab. 2, 89(25-26) : 502-509, 1934.

Interesting new Fusaria. Zentralbl. für Bakt., Ab. 2, 89(2526) : 509-514, 1934.

Descriptions of four new species of Fusaria on cacao in Central America. They are F. tumidum var. humi, F. sublimatum, F. elongatum and $F$. concolor.

Parasitic and other Fusaria counted in Costa Rica and Panamá soils. Zentralbl. Bakt. II Abt. 90:4-16, 1934. 
Soils and Fitsarium diseases. Zbl. Bakt. Abt. II, 91(11-15): 243-255, 1935.

The author states that various diseases caused by species of Fusarium appear to be correlated with soil conditions. Panama diseaso for instance, was found in Panama, Honduras and Costa Rica to be more severe on sandy than on elay soils. This fact is very important in control measures.

Cylindrocarpon fungus studies. Zbl. Bakt. Abt. II, 94(5-8) : 134-136, 1936.

Latin diagnoses are given of two new varieties of Cylindrocarpon (C. janthothele Wr. var. minus and C. olidium Wr. var. suaveolens, the perfect stage of the former being Nectria mammoidea Phil. \& Plowr. var. minor:) isolated from the soil of banana plantations in Honduras, Costa Rica, Panama and South America.

Cylindrocarpon isolation from tropical soils. Zbl. Bakt. Abt. II, 94(5-8): 137-142, 1936.

Cylindrocarpon olidum var. suaveolens, C. olidium, C. janthothele var. minus, C. curavatum and C. radicicola were isolated from banana plantations soils in Honduras, Guatemala, Costa Rica, Panama and Colombia. The phytopathological significance of these species of Cylindrocarpon has not yet been investigated.

Renacco, $\mathbf{R}$.

Sobre algunas enfermedades parasitarias de las plantas cultivadas. (On some parasitic diseases of cultivated plants.) An. Soc. Ciene. Argentina. 81:62-70, 1916.

Rhoads, Arthur S.

Clitocybe mushroom root rot. A new disease of banana. Phytopathology (Abstract) 22(23): 1, 1922.

Richardson Kuntz, P[edro Alejandro]

Estndios comparativos de las cañas lavangire, Zuinga y Cayanna 10. Ins. Expt. Sta. Puerto Rico. Circ. 73, 11 p., 1923.

Popular, comparative descriptions of these varieties and reference to its tolerance to sugar-cane mosaic.

La producción de nuevas variedades de caña y sus resultados experimentales. (Sugar-cane varieties production and its experimental results.) Ins. Expt. Sta. Puerto Rico. Bul. 38, 67 p., 1931.

Popular information of data of experimental field tests of new varieties of sugar cane in regard to susceptibility and immunity to the mosaic disease.

El mosaico en las nuevas variedades de caña de azúcar, P. R. 803, P. R. 807, F. C. 916 , y S. C. $12(4)$. Mosaic on the new 
sugar-cane varieties, P. R. 803, P. R. 807, F. C. 916 and S. C. 12(4).) Ins. Expt. Sta. Circ. 96, 10 p., 1932.

Field tests to try the above-mentioned varieties in regard to mosaic immunity. P.R. 803 and F.C. 916 are highly tolerant, P.R. 807 commereially immune and S.C. $12(4)$ used as check highly susceptible. Results given in tabular form.

Resistencia relativa al matizado de cañas producidas en el país comparadas con las importadas. (The relative resistance to mosaic of native grown and imported canes.) Ins. Expt. Sta. Puerto Rico. Cire. 101, 23 p., 1932.

Full details are given of the author's comparative observations on the relative productivity and resistance to mosaic of the locally pro. dueed and imported sugar-eane varieties in Puerto Rico. He reports that the Puerto Rico seedlings P.R. 803 and 807 and F.C. 916 were superior both in regard to yields and resistance to mosaie. Among the foreign, P.O.J. 2878 proved superior to B.H. 10(12) and S.C. $12(4)$ in both respects.

Cane varieties in Puerto Rico. Facts About Sugar 27(12):530532, 1932.

The author emphatically states that mosaic is the only sugar-cane disease of real economic importance in Puerto Rico. He also assures that its control today, presents virtually no diffeulty.

Rick, Johann

Fungos do Rio Grande do Sul (Brasil) (Fungi from Río Grande del Sur. Brazil.) Broteria 3:276-292, 1904.

Fungi austro-americani exs. fasc. I. Ann. Mycol. 2 : 406-410, 1904.

Ueber einige neue und Kritische Pilze Süd-Amerikas. Ann. Mycol. 2: 242-247, 1904.

Fungi austro-americani exs. fase. II. Ann. Mycol. 3:15-18, 1905.

Pilze aus Río Grande do Sul. Ann. Mycol. 3:235-248, 1905.

Fungi austro-americani exs. fasc. III \& IV. Ann. Mycol. 4: 309-312, 1906.

Pilze aus Río Grande do Sul. Broteria 5:5-53, 1906.

Fungi austro-americani exs. Fasc. V \& VI. Ann. Mycol. 5:2831, 1907.

Fungi austro-americani exs. fasc. VII \& VIII. Ann. Mycol. $5: 335-338,1907$. 
Fungi austro-americani exs. fasc. IX \& X. Ann. Mycol. 6: 105108, 1908.

Protobasidiomycetes do Brazil. Rel Geral 3 d. Congr. Scient. Latino-Amer. Río Janeiro 3(A) : 405-412. 1909.

Fungi austro-americani exs. fasc. XI-XVIII. Ann. Mycol. 9: 175-184, 1911.

Fungi gelatinosi et cartilaginosi. Rio Grandenses. Broteria 21: 134-141, 1924.

Monographia pezizinearum riograndensium. Broteria, ser. Bot. $25: 77-98,98-122,1931$.

Monographia bolinearum riograndensium. Broteria ser. Bot. 25 : 72-76, 1931. (Broteria Cient. Nat. 1:35-46, 1932.)

\section{Riddle, Iincoln W[are]}

An enumeration of lichens collected by Clara Eaton Cummings in Jamaica I. Mycologia 4(3): 125-140, 1912.

The lichens of Bermuda. Bull. Torrey Bot. Club. 43:145-160, 1916.

Some noteworthy lichens from Jamaica. Bull. Torrey Bot. Club. 44 : 321-330, 1917.

Lichens of St. Thomas. In Britton, N. L. The Flora of the American Virgin Island Brooklyn Bot. Gard. Mem. I: 109$115,1918$.

Lichens. In Britton, N.L. Flora of Bermuda. p. 470-479, 1918.

Lichens. In Britton, N. L. The Bahama Flora p. 522-553, 1920.

Ritchie, A. H. et al.

Woodpeckers and cacao. Journ. Jamaica Agric. Soc. 22(2) : 6569, (3) : 102-107, 1918.

Ritzema, Bos.*

Die Hexenbesen der kakao-baume in Suriname. Zeitschrift Pflanzen-krankheiten, Bd. 11:27, 1901.

* See also Bos. 


\section{Rogers, John $\mathbb{M}$., \& Earle, $\mathbf{P}$ [ranklin] S[umner]}

A simple effective method of protecting citrus fruits against stem-end rot. Phytopathology $7(5)$ : 361-367, 1917.

The method consist in shellacking the stem end, which is discussed in full. It is also recommended for other fruits as avocados, watermelons and many fruits to prevent stem end rot.

\section{Roque, Arturo}

Bacterial wilt of tobacco in Puerto Rico and its interstransmission to other solanaceous plants. Journ. Dept. Agric. Puerto Rico. 17(2) : 145-156, 1933.

The disease is due to Bacterium Solanacearum.

\section{Rorer, J[ames] B[irch]}

Preliminary report on cacao spraying experiments. Bull. Dept. Agric. Trinidad 9(64):10-14, 1910.

A bacterial disease of bananas and plantains. Soc. Peper 412. Proc. Agrie. Soc. Trinidad 10(4) : 109-113, 1910.

Popular. Cause of disease not given. Refers to F. S. Earle's Report of a trip to Jamaica which was published in Journ. New York Bot. Garden 4(37): 8, 1903. Reprinted in West Indian Bull. 4(1):6, 1904.

The bud-rot of the coconut palm. Dept. Agric. Trinidad Bull. 9(64) : 22-24, 1910.

Popular.

The witch broom disease of cacao in Surinam. Dept. Agric. (Trinidad) Bull. 9(64) : 32-37, 1910.

A general discussion. Colletotrichum luxifoum has been found on diseased material but the anthor states in a foot note that there is no proof that it is the causal crganism.

The relationship of black rot of cacao pods to the canker of cacao trees. Dept. of Agric. (Trinidad) Bull. 9(64) : 38, 1910. 1910.

The two diseases are due to Phytophthora omnivora.

Pod-rot, canker, and chupon-wilt of cacao caused by Phytophthora sp. Dept. Agric. Trinidad. Bull. 9(65) : 79-103, 1910.

The author gives a history of the disease. Dr. de Verteuil in a book published in 1727 says: "In the year 1727 however, a terrible epidemic spread in the cacao plantations of 'Trinidad." He deseribes the disease and gives the results of studies.

When inoculations have been made with pure cultures of a number of these fungi the results have been uniformly negative so that NeCtria theobromae, N. bainii, Calonectria flavida, two undetermined species of Sphaerostilbe frequently found on cankered cacao bark, and 
Spicaria colorans cannot well be considered as the cause of cacao canker, or of the cacao pod disease.

A large number of inoculation experiments made by the writer with pure cuitures of Phytophthora omnivora (q) proves conclusively that this fungus is the cause of the common cacao-pod-rot and of the disease lnown as canker, and that the diseased pods serve as the chief source of infection of the tree.

Report of the Mycologist for the year ending April 30, 1910. Bull. Dept. Agrie. Trinidad 9(65) : 154-159, 1910.

General statement of diseases of several plants. Mentions Septooylindrium suscepectus of coconut. Glocosporium mangiferae P. Henn. on fruit of mangoes.

Diseases of bananas. Bull. Dept. Agric. Trinidad. 9(65): 157, 1910.

A bacterial disease of banana and plantains. Proc. Agric. Soc. Trinidad and Tobago 10:109-113, 1910.

A bacterial disease of bananas and plantains. Phytopathology $1(1): 45-49,1911$.

Report of Mycologist. Trinidad Royal Gaz. 80:430, 1911.

Annual report of the Mycologist. Trinidad Bd. Agric. Ann. Rpt. $1910: 8,1911$.

A preliminary list of Trinidad fungi. Board Agric. Trinidad \& Tobago. Cixc. 4, 1911.

Diseases of the coco-nut palm. Dept. Agric. Trinidad \& Tobago. Circ. 4: 27-33, 1911.

Bud-rot of the coconut palm. Dept. Agric. Trinidad \& Tobago. Bull. 11(70) : 68-69, 1912.

Popular.

Some fruit diseases. Dept. Agric. Trinidad \& Tobago, Bull. 11 (70) : 75-76, 1912.

Popular, refers to Gloeosporium mangifera on mango and avocado.

Bud rot of the coco-nut palm. West Indian Bulletin 12(4): $443-445,1912$.

A general discussion.

Spraying cacao. West Indian Bulletin. 12(3):275-277, 1912. (Dept. Agric. Trinidad \& Tobago. Bull. $11(70)$ : 34-35, 1912.) Results of spraying for Phytophthora faberi. 
Some fruit diseases. West Indian Bulletin 12(4):464-465, 1912.

A brief reference to Gloeosporium mangiferae of the mango, and alligator pear, Panama and Moko (bacterial) diseases of bananas.

The Suriname witch-broom disease of cacao. Board Agric. Trinidad \& Tobago, Circ. 10, 13 p., 1913.

This paper includes the history of the disease, a description of symptoms, mycological studies, inoculation experiments and remedial measures.

The witch-broom disease in Surinam. Trinidad \& Tobago Dept. Agric. Bull. 12(72) : 70-71, 1913.

A brief note.

Fungus diseases of casava. Bull. Dept. Agric. Trinidad \& Tobago 14(2) : 36-38, 1915.

A popular paper in which the author says: "Leaf diseases attributed to different species of Cercospora, C. manihotis, C. cassavae, C. henningsii and to Glocosporium manihoti have been reported from Brazil and adjacent parts of South America, Cuba, Florida and Tropical Africa, in fact from practically all countries where cassava is grown. The species of Cercospora cause leaf spots while Glocos. porium manihoti attacks chiefly the leaf stalk and causes the whole leaf to wilt."

The author also refers to two stem diseases caused by Bacillus manihotus and Gloeosporium manihoti in Brazil. Also to root disease in Jamaica.

The anthracnose of the mango. Bull. Dept. Agric. Trinidad \& Tobago 14(5):164-171, 1915.

A popular description of the disease, infection experiments, spray. ing and shipping experiments.

A disease of immortal trees. Bull. Dept. Agric. Trinidad \& Tobago 14(4) : 128-129, 1915.

Coconut bud rot. Bull. Dept. Agric. Trinidad \& Tobago, 14 (4) : 129-130, 1915.

A statement as to number of trees destroyed. Also that some organism other than Bacillus coli may be an important factor.

Citrus canker, Bull. of the Dept. Agric. Trinidad \& Tobago. $14(4): 130-131,1915$.

A popular description. 
Fungous diseases of limes. Proc. Agric. Soc. Trinidad \& Tobago, $15(1): 14-15,1915$.

A brief popular account in which the author mentions collar and root rots.

Pink disease of cacao. Bull. Dept. Agric. Trinidad \& Tobago $15(3): 86-89,1916$.

Popular historical sketch, deserpition and control. Caused by Corticium sclmonicotor $\mathrm{B}$. et $\mathrm{Br}$. which has been wrongly determined as Corticium tilacino-fuscum.

The Suriname witch-broom disease of cacao. Bull. Dept. Agric. Trinidad \& Tobago 15(1): 5, 1916.

A bricf nopular statement, based on the author's Circular 10 Board of Agric. Trinidad \& Tobago (July 30, 1913).

Cacao disease in Ecuador. Proc. Agric. Soc. Trinidad \& Sobago. $16(4)$ : 334-336, 1216.

A letter from Mr. Rorer.

Plant diseases and pests. The pink disenso of cacao. Bull. Dept. Agric. Trinidad \& Tobago 14(1):1-4, 1915.

A preliminary list of Trinidad fungi. Peport of the Mycologist for the year ending March 31, 1911. (Part II.) Board Agrie. Trinidad \& Tobago Circ. 4:37, 46, 1916.

The South American Hcrea leaf disease. Bull. Dept. Agric. Trinidad \& Tobago, 16(3): 128-129, 1917.

A brief report. Dr. Gerold Stahel of Suriname says that it is caused by a fungus, one stage of which is Scolicctrictum.

Caca spraying experiments. Bull. Dept. Agric. Trinidad \& Tobago, 16(3) : 165-167, 1917.

Gives results and costs.

Algal disease of cacao. Proc. Agric. Soc. Trinidad \& Tobago $17(6): 345-348,1917$.

Popular.

Enfermedades y plagas del cacao en el Ecuador, y métodos modernos apropiados al cultivo del cacao. (Diseases and pests of cacao in Ecuador and modern and appropiate methods of cacao culture.) Ambato, Ecuador, Assoc. Agric. Ecuador, 80 p., 1918. 
The fungous diseases of roses and their treatment. Trinidad \& Tobago Dept. Agrie. Bull. $18(1): 29-31,1919$.

The author describss black spot (Diplotia carpon rosae Wall.) (Actinonema rosae), leaf spot (Cercospora rosacicola Pass.), powdery mildew Sphaerothcea panosa Lev.), red rust (Cophalezrus virescens and rose eanker (Stilbum sp.) and gires treatment.

The fungons discases of avocados. Triniclad \& Tobago Dept. Agric. Bull 18(3) : 132-133, 1919.

A description of the anthraenose disease and of a dic-back of twigs that are infected with Diplodia cacaoicola.

The wither-tip of limes. Trinidad \& Tobago Dept. Agric. Bull. $18(9): 1-3,1919$.

The disease is eaused by Gloeosporium limetticotum Clausen. The author describes the symptoms and treatments.

Emador cacan succumbing to pests. Tea $\&$ Coffee Trade Journ. 소(6) : 919 921, 1925.

\section{Rosenfeld. A[rturo] Hrinton]}

Kovanoene: Puerto Rito"s mosaic disenseresisting canes. Int. Suger Journ. 22(253): 26-33, 1920.

Asperto beneficioso del mosaico de la cañn de arúcar. (Beneficial aspect of the sugarmeane mosaic divesse) Rev. Agric. Pnerto Rien 12(1): 7-14, 1924. (Tnt. Sugn Tourn. 26(304): 191-195, 1924.

In causa del matizado. Un paso hacia la solución de este misterio. (The canse of mosaic. One step toward the solution of this mystery.) Rev. de Agric. Puerto Rico 13(3): 145-148, 1924. (Int. Sugar journ. 26(310):535-536, Fact About Sugar 19(18):425, Tropical Agric. (Ceylon) 63(1):38-40, 1925.)

The Java P.O.J. Canes in Tucumán and Puerto Rico. Dept. Aprie. Journ. Ins. Expt. Sta. 8(3) : 1-44, 1925.

Gelceción de caña para la plantación. (Sugar cane selection for the planting.) Sugar 28(3) : 153-155, 1926 .

The sugar industry of Perú. Trop. Research Foundation Sci. Contribution 6, 27 p., 1926. (Facts About Sugar 21 (3) : 50-52, 1926. Intern. Sugar Journal 28(335) : 590-597, 1926.) 
Lessons from the renaissance of a sugar industry. Int. Sugar Journ. 29(348) : 634-641, 1927. (Rev. Appl. Mycol. 7:400401, 1927.

The author discusses the relationship of mosaic to varieties.

\section{Rowlee, Silence}

A collection of Costa Rican fungi. Mycologia 16(3) : 115-121, 1924.

\section{Russell, T. A.}

Report of the plant pathologist, 1933. Bermuda Dept. Agric. Ann. Rpt. 1933: 28-36, 1934.

Scab spot or bacterial spotting of tomatoes. Bermuda Bd. Agric. Bull. 14(9) : 67-68, 1935.

Notes on a bacterial disease (Bacterium vesicatorium) that caused 50 per cent of losses of the tomatoes grown in Bermuda. Control attempts are given.

Plant pathological Report, 1935. Bermuda Bd. Agric. Rpt. $1935: 18-23,1936$.

This report contains several items of phytopathological interest.

Diseases and pests of tomatoes in Bermuda. Trop. Agric. (Trinidad) 13(3):71-78, 1936.

A brief report in the following fungi and bacteria are recorded: Fusarium lycopersici var. bulbigenum, Septoria lycopersici, Cladosporium fulvum, Sclerotinia sclerotiorum, Bacterium vesicatorium, Rhizoctonia (Corticium) solanii, Phoma destructiva, Phytophthora infestans, and Bacillus aroideae.

\section{Ryan, Ruth W[imfred]}

The microthyriacea of Puerto Rico. Mycologia 16(4) : 177-196, 1924.

The development of the Perithecia in the Mycrothyriaceae and a comparison with Metiola. Mycologia 18(3):100-110, 1926

Saccardo, Pier Andrea, \& Sydow, Hans.

[In] Saccardos' Sylloge Fungorum 16: 625, 1902.

Notae mycologicae. Ann. Mycol. 3:165-171, 1905.

Mycomycetes americani novi Lecti a Cl. doctoribus C. E. Fairman et S. Bonansea. Journ. Mycol. 12:47-52, 1906.

Notae mycologicae, ser. XIV. Ann. Mycol. 10:310-322, 1912. 
Noate mycologicae. Ann. Mycol. 11:14-21; 546-568, 1913; 12 : 282-314, 1914; $13: 115-138,1915$.

Thirteen species from Uruguay.

\section{Sáenz F., Roberto, \& Chavarria A., Carlos}

Enfermedades del cafeto. La chasparria (Cercospora coffeicola) (Coffee tree diseases. "La chasparria" (Cercospora coffeicola) Rov. Inst. Def. Café, Costa Rica 2(9) : 193-202, 1935.

Popular account of a coffee disease caused by the fungus Cercospora coffeicola. Reviewed the work of Fawcett and Cook in Puerto Rico and Donald in Africa.

Sauri, F.

El mosaico de la caña de azúcar. (Sugar-cane mosaic.) Rev. Agric. Rept. Dominicana, 18(6) : 101-104, 1923. Popular.

\section{Schelotto, Bartolomé}

Algunas investigaciones sobre la "caries" del trigo. (Some investigations on wheat rust.) Bol. Chacra Expt. de La Previsión. Argentina 1(4): 40-47, 1933.

Experimental data in regard to behaviour of some wheat hybrid varieties.

Schilling, Fr.

Entwicklingsgeschichtliche und systematische untersuchung epiphyller Flechten. Hedwigia 67(6) : 269-300, 1927.

\section{Seaver, Fred J[ay]}

The Hypocreales of North America-II. Mycologia 1(5) : 177207, 1909.

Hypocreales. North America. Flora. 3:1-88, 1910.

Hypocreales of North America-III. Mycologia 2(2):48-93, 1910.

Some tropical cup-fungi. Mycologia 5(4) : 185-193, 1913.

Illustrations and descriptions of cup-fungi II. Sepultaria. Mycologia 7(4) : 197-199, 1915.

North American species of Ascodesmis. Mycologia 8(1):1-4, 1916.

Photographs and descriptions of cup-fungi IV. Peziza clypeata. Mveologia 8(5) : 235-238, 1916.

Bermuda fungi. Mem. New York Bot. Gard. 6:501-511, 1916.

Fungi; In Britton, N. L. Flora of Bermuda. p. 489-540, 1918. 
Fungi; In Britton, N. L. The Bahama Flora p. 631-645, 1920.

Notes on North American Hypocreales. IV, Aschersonia and Hypocrella. Mycologia 12(2): 93-97, 1920.

Studies in Tropical Ascomycetes-I. Neopeckia diffusa and Herpotrichia albidostoma. Mycologia 14(5) : 235-238, 1922.

Phyllostictaceae. North American Flora. 6:3-84, 1922.

Mycological work in Puerto Rico and the Virgin Islands. Journ. New York. Bot. Garden. 24(281) : 99-101, 1923.

Studies in Tropical Ascomycetes-II. An interesting Zylaria from Puerto Rico. Bull. Torrey Bot. Club. 50: 307-310, 1923.

The fungous flora of St. Thomas. Mycologia 16(1) :1-15, 1924.

Additions to the rust flora of the West Indies. Mycologia 16 (1) : 46-48, 1924.

The fungus flora of St. Croix. Mycologia 17(1):1-17, 1925.

Studies in tropical Ascomycetes III. Puerto Rican eup-fungi. Myeologia 17(1) : 45-50, 1925.

\& Chardon, Carlos E[ugenio]

Botany of Puerto Rico and the Virgin Islands: Mycology, Sci. Survey of Puerto Rico and the Virgin Islands. New York Acad. Sci. 8(1) : 1-208, 1926.

Mycologieal work in Bermuda Island. Mycologia 18(4) : 137$138,1926$.

Mycological work in Bermuda. Journ. New York Bot. Gard. $27(317): 90-93,1926$.

Studies in tropical Ascomycetes-IV. Some Hypocreales from Trinidad. Mycologia 20(2):52-59, 1928.

Studies in Tropical Ascomycetes-V. Species of Phyllachora. Mycologia 20(4) : 214-225, 1928.

The North American cup-fungi (Operculales) 284 p., New York, 1928.

Chardon, Carlos E[ugenio]; Toro, Rafael A[ndrés],

\& Kern, Frank D[unn]

Botany of Puerto Rico and the Virgin Islands. Supplement to Mycology. Sci. Survey of Puerto Rico \& the Virgin Islands. New York Acad. Sci. 8(2) : 209-311, 1932. 
Sén, Jir.. Firancisco]

Sugur :aue rustic and other grasses. Ins. Expt. Sta. Report of tive Div. of tint. Puerto Rico. 1923-24: 114, 1924.

Report of experiments in progress in relation to mostic transmission using different aphid species.

$\Delta$ new nechanicai method for artificially transmitting sugar-cane inosaic Journ. Dept. Agrit. Puerto Rico 14(2) : 49-68, 1930.

The auther describes a new method in which he uses very fine insect pins. The spindle of a diseased plant is removed and placed in close contact with the spindle of a healthy plant. The pins are puslied throngh the diseased and into the healthy plant. The author reports a high percentage of infection.

Arifinial transmission and other studies on sugar-cane mosaic. Wouth Congress Intorn. Sos. Sugar-Cane Technologists, Puurto Rico, 1932. Bull. 84, 6 p., 1933.

The author discusses the stbject under widely different points of vicw. Some of then towards the nature of the virus and others dealing with its mechanieal and insect transmission Aphis maidis is conclnsirely a carrier of the disease.

Serrano, Intis Arntonio]

Mosaico (Mosaic). Imp. Eolívar, Caracas, Venezuela 16 p., 1927.

Rcport of a trip of iuspection made by the author to the northern sugar-cane region of Venezucia. It includes a brief reviow of the work of others and a short historical sheteh. Gives synuptoms and methods of control and prevention.

Sharples, A.

Ustulina zonata (Lev.) Sace. on Hevea brasiliensis. Ann. Appl. Biol. $4(4): 153-178,1918$.

The fungus is common on fallen trunks and on old stumps of rubber and soft wood trees. It is the eallse of a collax rot. The paper contains a deseription and recommendations for control.

Shepard, $\mathbb{O}$. ' $\mathbf{X}$.

The cacao industry of Trinidad. Trop. Agric. (Trinidad) 9 (11) : $334-345,1932$.

The drawback of the industry in Jamaica is due to witches'-broom (IIrasmius porniciosus).

Silinga Mulder, J.

De riekte is de Congol-anaan in Suriname. Indische Mercuur $57(23): 344,1934$.

Simonetto, Mi[oisés]

Plan de investigaciones urgentes sobre las causas concomitantes de la plaga mosaico en la caña de azúcar. (Plan of urgent investigations about the symptomatic causes fo the sugar-cane mosaic disease.) Rev. Acric. Com. y Trab. Cuba 3(9):351, 1920. 
444 THE JOURNAL OF AGRICULTURE OF THE UNIVERSITY OF P. R.

Nuevas orientaciones en sanidad vegetal. (New orientations about vegetable sanitation.) Rev. Agric. Com. Trab. Cuba. 3(9) : 349-356, 1920.

Las Rayas amarillas en la Caña de Azúcar. (Yellow stripes of sugar cane.) Cuba Azucarera, Sept. 15, p. 14, 1920.

La enfermedad de las rayas amarillas en la caña. Su importancia y extensión en Cuba. (The yellow-stripe disease in Cane: Its importance and extension in Cuba.) Oficina de Sanidad veg., Sec. Agric. Com. y Fábrica de Cuba. Bol. 3, 63 p., 1921.

The author gives a general discussion with recommendations for control.

La enfermedad de las rayas amarillas en la caña de azúcar. Réplica al Dr. S. C. Bruner. (The yellow stripe disease of sugar cane. Reply to Dr. S. C. Bruner.) Rev. Agric. Com. y Trab. Cuba 5(4) : 11-13, 44-48, 1922. (Sugar 24: 641-642, 1922.)

Controversial. A reply to Dr. S. C. Bruner.

Cómo se debe determinar con buena aprorimación el porcentaje de cañas enfermas en un cañaveral infectaddo con el mosaico. (How to determine approximately the percentage of diseased canes in a cane field infested with the mosaic.) Rev. Agric. Com. y Trab. Cuba 5(3): 26-27, 1922.

Sintenis, P.

Pilzen auf der insel Portorico 1884-1887 gasammetten. Engler. Bot. Jahrb. 17: 489-501, 1893.

Fungi studied by Bresadola, Hennings and Magnus.

Skutch, A. F.

The anatomy of the rhizome of the banana in relation to infection by Panama disease. United Fruit Co., Res. Dept. Bull. 36, 7 p., 1931.

Small, W.

Mycological Notes. Note on the parasitism of Macrophomina phaseoli. (Maubl.) Ashby. Rhizoctonia bataticola (Taub.) Butler. Trop. Agrie. (Trinidad) 5(12): 315-322, 1928.

This is a discussion of work in Ceylon, Java, Sumatra, Burma and Southern Rhodesia. It is followed with comments by H. R. BritonJones. 
444 THE JOURNAL OF AGRICULTURE OF THE UNIVERSITY OF P. R.

Nuevas orientaciones en sanidad vegetal. (New orientations about vegetable sanitation.) Rev. Agric. Com. Trab. Cuba. 3(9) : 349-356, 1920.

Las Rayas amarillas en la Caña de Azúcar. (Yellow stripes of sugar cane.) Cuba Azucarera, Sept. 15, p. 14, 1920.

La enfermedad de las rayas amarillas en la caña. Su importancia y extensión en Cuba. (The yellow-stripe disease in Cane: Its importance and extension in Cuba.) Oficina de Sanidad veg., Sec. Agrie. Com. y Fábrica de Cuba. Bol. 3, 63 p., 1921.

The author gives a general discussion with recommendations for control.

La enfermedad de las rayas amarillas en la caña de azúcar. Réplica al Dr. S. C. Bruner. (The yellow stripe disease of sugar cane. Reply to Dr. S. C. Bruner.) Rev. Agric. Com. y Trab. Cuba 5(4): 11-13, 44-48, 1922. (Sugar 24:641-642, 1922.)

Controversial. A reply to Dr. S. C. Bruner.

Cómo se debe determinar con buena aprorimación el porcentaje de cañas enfermas en un cañaveral infectaddo con el mosaico. (How to determine approximately the percentage of diseased canes in a cane field infested with the mosaic.) Rev. Agric. Com. y Trab. Cuba 5(3): 26-27, 1922.

Sintenis, P.

Pilzen auf der insel Portorico 1884-1887 gasammetten. Engler. Bot. Jahrb. 17: 489-501, 1893.

Fungi studied by Bresadola, Hennings and Magnus.

Skutch, A. F.

The anatomy of the rhizome of the banana in relation to infection by Panama disease. United Fruit Co., Res. Dept. Bull. 36, 7 p., 1931.

Small, W.

Mycological Notes. Note on the parasitism of Macrophomina phaseoti. (Maubl.) Ashby. Rhizoctonia bataticola (Taub.) Butler. Trop. Agrie. (Trinidad) 5(12) : 315-322, 1928.

This is a discussion of work in Ceylon, Java, Sumatra, Burma and Southern Rhodesia. It is followed with comments by H. R. BritonJones. 


\section{Smart, H. P.}

Sigatoka-leaf disease of bananas (Cercospora leaf-spot). British Honduras Dept. Agric. Leaflet 3, 7 p., (n.d. 1936).

Popular account of a banana-leaf disease eaused by the fungus Cercosporae musae Zimm. Symptoms, effect of climate, season and external factors, methods of spread and control are given.

\section{Smith, Charles Leonard}

Some Central American Pyrenomycetes. Iowa Univ. Lab. Nat. Hist. 2(4) : 394-415, 1893.

\section{Smith, Erwin F[rink]}

The bud rot of the coco-nut palm in the West Indies. Abstr. of paper Proc. 8th Ann. Meeting of Society for Plant Morphology and Physiology. Philadelphia Dec. p. 28-30, 1904.

A report of the disease in Cuba.

The bud rot of the coco-nut palm in the West Indies. Science n. s. $21(535): 500-502,1905$.

The bud rot of the palm in the West Indies. Proc. Agric. Soc. of Trinidad. 6:208-211, 1906.

Popular. It appears that this paper was published in Dept. of Agric. Jamaica, March, 1905.

A Cuban banana disease. Science, (Abstract) N. S. 31:754-755, 1910.

Bacteria in relation to plant diseases. Carnegie Inst. of Washington 3, 170, p. 1914.

Bacterial diseases of plants. W. B. Saunders Co., Phil. \& London, 1920.

The following tropical diseases. Bacterium phas zoli, B. malvacea. rum

Smith, F. F. V.

Plant diseases in Jamaica in 1927. Dept. Agric. Ann. Rpt. 1927 : 18-19, 1927.

Brief notes on crop plant diseases.

Plant diseases and pests. Jamaica Dept. Agric. Ann. Rivt. 1929: 15-21, 1930.

The leaf diseases of Irish potatoes in Jamaica. Journ. Jamaica, Agric. Soc. 25(11) : 489-494, 1931.

Popular. 
The banana industry in Portland. Jamaica Gaz. 54(34) : 703704, 1931.

A brief reference to the Panama disease.

Plant diseases in Jamaica in 1930. Ann. Rpt. of the Govt. Microbiologist. Ann. Rpt. Sci. \& Agric. Jamaica. 1930:1519, 1931.

Sclerotium disease. Jour. Jamaica Agric. Soc. 36(4) : 129-130, 1932 .

Stem end rot of citrus and its control in the packing house. Journ. Jamaica Agric. Soc. 36(2) : 59-64, 1932.

Studies on Diplodia natalensis.

Panama disease of bananas in Jamaica. Jamaica Dept. Sci. \& Agric. Microbiol. Bull. 1, 22, p., 1932.

An extensive report. Evidence that the disease was in the island as early as 1902 .

The use of chemical for killing bananas in the treatment of Panama disease. Trop. Agric. (Trinidad) 9(3) : 83-86, 1932.

Oil kills the banana and appears to inhibit the growth of Fusarium cubense.

Coconut disease in St. Mary. Journ. Jamaica Agric. Soc. 36 (9) : 448-452, 1932.

Two forms of the bronze wilt disease.

Plant diseases in Jamaica in 1932. Report of the Government Microbiologist. Ann. Rept. Dept. of Sci. and Agric. Jamaica for the year ending 31st December 1932:13-16, 1933.

Discusses Fusarium cubense, Phytophthora palmivora, Rhizoctonia (Corticium) solani, Cladosporium and Phytophthora infestans.

\section{Smith, Longfield}

Sugar cane in St Croix, Virgin Islands, Agricultural Experiment Station, Bull. 2, 23 p. 1921.

On page 23, the author mentions Marasmins sacchari, Colletotrichum falcatum and Thielaviopsis ethaceticus.

\section{Smith, Roger C., \& Barker, H[enry] D.}

Observations on the "yellow disease of beans and related plants in Haiti." Journ. Econ. Ent. 23(5) : 843-847, 1930.

The disease is either eaused by a virus which is transmitted by a leafhopper (Empoasca sp.) or eaused by the insect. It is not transmitted in the seeds. 


\section{Snyth, झाugene] G[raywood]}

Entomological Work. (rhe yellow stripe disease of sugar cane.) Report of the Com. of Agric. \& Iabor of Puerto Rico. From Thepont of the Governor 1018:685-713, 1919.

Insects and mottling diseases. Journ. Dept. Agric. Puerto Rico 3(4) : 83-116, 1919. (Rev. App. Ent. Ser. A. 8:433, 1919.) Gives a record of experiments conducted in all efiort to determine the insect earriers of the disease. The results were negative.

List of the insects and mite pests of sugar cane in Puerto Rico. Joum. Dept. Agric. Puerto Rico. 3(4): 135-150, 1919.

A paper prepared during the author's studies on insect transmission of the sugar-eane mosaic.

Report Division of Entomology. Ins. Expt. Sta. Puerto Rico. Än. Rpt 1919-20:83-89, 1920 .

Solheim, W[ilhem] G[erhard] \& Stevens, F[rank] L[incoln] Cercospora studies. II. Some Tropical Cercosporac. Mycologia $23(5): 365-405,1931$.

Soriano, \$.

Notas micológicas. Sobre el cultivo en medios artificiales de algunos hongos parásitos de plantas. (Cultures of some fungi parasitic to plants in artificial media, Rev. Fac. Agron. $y$ Vet. (Buenos Aires) 6(2): 89-114, 1928.

Studies of fungi in Argentine.

Cultures de champignons parasites de plantes. (Cultures of fungi parasitic on plants.) Compt. Rend. Soc. Biol. (Paris) 99(31): 1930 .

A study of cultures made from Argentinian fungi.

El "corcovo" y el "polvillo" del tabaco en la República Argentina. (The "huneh-back", and the "powdery" of tobacco in the Argentina Republic.) Argentina Rev. Fac. Agron. \& Vet. $7(2): 371-392,1931$.

Account of these two diseases occurring in the Argentine liepublic. The two diseases are fully described and the author concludes that "corcovo" and "polvillo" are varying manifestations of a single disease of the virus group. Both are decidedly infectious.

Sosa, H. A.

Como evitar las enfermerlades en las plantas. (How to prevent plant diseases.) Defensa Agric. (Uruguay) 1: 141-144, 1920. 
449 THE JOURNAL OF AGRICULTURE OF THE UNIVERSITY OF P. $R$.

\section{South, F. W.}

Report on the prevalence of some pests and diseases in the West Indies for the year 1909-10. I. Fungoid diseases. West Indian Bull. 11(2) : 73-85, 1911.

An important list with geographical distribution.

The control of scale insects in the British West Indies by means of fungoid parasites. West Indian Bull. 11(1) : 1-33, 1910.

A very comprehensive paper on the fungous parasites of seale insects.

Root diseases of cacao, lime and other plants. Agric. News. 9(223) : 366, 367, 1910.

Fungus diseases of ground nuts in the West Indies. West. Indian Bull. 11(3) : 157-160, 1911.

A brief account of rust Uredo arachidis (Uromyces arachidis) in St. Vincent; Cercospora personata which was originally deseribed as Cladosporium personatum and has been found on Cassia occidentalis. The paper gives a bibliography.

Observations on root diseases in the West Indies. Agric. News 10(249) : 366-367, (250) : 382-383, 1911.

Fungoid diseases. West Indian Bulletin 11(2):95-106, 1911. A brief statement of diseases prevalent in 1909-10.

Fungus diseases of cacao. West Indian Bulletin. 12(3) : 277302, 1912.

Popular discussion of Phytophthora rot (Phytophthora faberi), Thyridaria rot (Thyridaria tarda), Anthracnose (Colletotrichum sp. Jamaica), pod disease, ete.

\& Brooks, A. T.

Report on the Rosellinia root disease of cacao in St. Lucía. Imp. Dept. of Agric. for the West Indies. Circ. No. 2, 1912.

Further notes on the fungus parasites of scale insects. West Indian Bull. 12(4) : 403-412, 1912.

A general discussion and records.

Fungus diseases. West Indian Bulletin 12(4) : 425-443, 1912.

A list of common diseases and geographical distribution.

Some root diseases of permanent crops in the West Indian. West Indian Bull. 12(4) : 479-498, 1912.

Discussion of Thyridaria tarda which attacks cacao, limes, Castilloa and Erythrina spp., Liberian coffee, mangoes, oranges, Inga laurina, breadfruit, sugar cane, Cassia fistuia, eassava and bitter oranges. Also notes on black rot and red root rot. 


\section{Souza, Raúl Germano}

O Tylenchus acuto-candatus (?) nos cafezaes de Indaiatuba. Tylenchus acuto-candatus (?) in our coffee groves of Indaiatuba.) Bol. Agric. Sec. Agric. Com. e Obras Pub. S. Paulo $17(9): 726-736 ;$ (11) : 873-878, 1916.

\section{Spegazzini, Carlos [Liugi]}

Fungi Argentini. Anal Soc. Cient. Argentina 9: 158-192; 278$285 ; 10: 5-33,59-64 ; 122-142 ; 145-168,1880$.

Fungi Argentini additis nonullis Brasiliensibus Montevideensibusque pugillus (Reprinted as 1-4, 1880-83, 138 p.) Anal Soc. Cient. Argentina 12:12-30, 63-82, 97-117, 174-189, 208-227, 241-258, 1881. 13:11-35, 50-64, 1882.

Importancia de los vegetales en la economía de la Naturaleza, especialmente respecto a las criptógamas. (Importance of plants in the economics of Nature especally the cryptogamics.) Bol. Mens. Dept. Agrie. (Argentina) 5:268-275, 1882.

Los secretos del Chaco. (The Chaco secrets.) Bol. Dept. Agric. (Argentine) 7:379-384, 1883.

Fungi guaranitici. Anal Soc. Cient. Argentina 16:242-248; 272-280, 1883. 17:42-48, 69-96; 119-134, 1884. 18:263286 , 1884. 19:34-48; 91-96; 241, 265, 1885; 22:186-224, $1886 ; 26: 5-74,1887$.

Las falvideas Argentinas. (The falvides from Argentine.) Anal Soc. Cient. Argentine 24:59-68, 1887.

Las tarifas Argentinas. Anal. Soc. Cient. Argentina 24:120127, 1887.

Fungi patogonici. Bol. Acad. Nac. Córdoba, Argentina. 11:564, 1887.

Fungi fuegiani. Bol. Acad. Nac. Córdoba, Argentina 11:135308, 1888.

Fungi Puiggarini. Bol. Acad. Nac. Córdoba 11:381-622, 1889.

Phycomyceteae Argentinae. Rev. Argentina, Hist. Nat. 1:2838. 1891.

Nonulli nov. v. critici. Rev. Argentina Hist. Nat. 1:101-111; 168-177; 298-432, 1891.

La gangrena húmeda: Polvillo de la caña de azúcar, en Tucumán, 1895. 
Hongos de la eaña de azúcar. (Sugar-eane fungi.) Rev. Facul. Agron. \& Vetr. La Plata. Argentina. 2:227-258, 1896.

Las enfermedades del eafeto en Costa Rica. (The coffee diseases of Costa Rica.) Rev. Facul. Agron. \& Veter. La Plata. 2: 339-340, 1896. (Anales Inst. Fis. Geog. Nac. Costa Rica $7: 123-126,1897$.

Fungi Argentini novi v. critici. II. Anal. Must. Nac. Buenos Aires 6(3) : 81-365, 1898-99.

Enfermedades en la alfalfa. (Alfalfa diseases.) Crónica Agricola 1(13) : 212-214, 1905.

Enfermedades en las higneras (Myililaspis gloveri) (Fig plant diseases (Mytilaspis gloveri) Crónica Agrícola 2(1):22, 1906.

Aigunos hongos del cacao. (Sonic cacao fungi.) Rev. Facult. Agron. \& Vet. La Pílata 2 Ser. 2(4-6):303-311, 1906.

Fungi aliquot Panlistari. Rev. Mus. La Plata. 15: 7-48, 1908.

Una enfurmedad en los noga?es. (A chestnut disease). Crónica Agrícola 2(7-9) : 108-109, 1908.

Hongos de la yerba maté. (Maté fungi.) Anal Mus. Nac. Buenos Aires 3(10): 111-141, 1909.

Myeetes Argentinensis-iV. Arai. Mus. Nae. Buenos Aires $13: 325,1909$.

Breve nota do mico!ogía. (Brief mycological note.) Rev.. Chilena Hist. Nae. 13:20-21, 1909.

Ramilletes de hongos chilenos. (Bunch of Chilean fungi.) Rev. Facul. Agron. \& Veter. La Plata 6:1-205, 1910.

Fungi chilensis. Contribución al estudio de los hongos Chilenos. (Chilean fungi. Contribution to the study of the Chilean fungi.) Libroría Nacional, Buenos Aires, 205, p., 1910.

Contribución al esturio de las laboulbenio-miectas argentinas. (Contribution to the study of the labouibeniomycetes from Argentina.) An. Mus. Nac. Buenos Aires 23:167-244, 1912.

Mycetes argentinensis. Ser. II-IV. Anal. Mus. Nac. Buenos Aires 1:49-89, 1902; 9:25-33, 1906; 12:257-457, 1909; 13: $329-476,1911 ; 23: 1-147,1912 ; 24: 167-186,1913$. Ser. I. 
Reprinted from An. Soc. Cient. Argentina 47:262-273, 1899. 50:33-39, 1900. Ser. III ommitted in numbering but series IV in two parts.)

Revision de las Laboulbeniales Argentinas. (Revision of the (Argentine Laboulbeniales.) Anal. Mus. Nac. Hist. Nat. Buenos Aires 29: 445-668, 1917.

Breves apuntes sobre Himenogastreas sud-americanas. (Brief notes on South-American $H y$ menogastreae.) Rev. Chilena Hist. Nat. $21: 167-171,1917$.

La tuberculosis del Ligustrum japonica. (Tuberculosis of Ligustrum japonica.) Rev. Asoc. de Estudiantes Agron. \& Vet. La Plata. (Argentine) 1(1):1919.

Los hongos de Tucumán. (The fungi of Tucumán.) Paper presented to the First MItg. Nac. Soe. Argentine Cient. Nat. ṛ̂tumán p. 254-274, 1919.

Relique mycologicae tropicae. Bol. Acad. Nac. Cient. Córdoba 23: 365-609, 1919.

Algunas observaciones relativas a las hojas de coca. (Some observations in relation to the coca leaves.) Anal. Soc. Cient. Argentina $90: 23-32,1920$.

Sribre algunas enfermedades y hongos que afectan las plantas de "Arrios" en el Paraguay. (On some diseases and fungi whish alfect the citrus plants in Paraguay.) Anal. Soc. Cient. Argentina 90:155-188, 1920.

Dos micromicetos chilenos nuevos. (Two new chilean micronyeetes.) Rev. Chilena Hist. Nat. 24: 12-15, 1920.

Descripeión de hougos mirmecófilos. (Description of mirmecofile fungi.) Rev. Museo de la Plata 26: 166-174, 1921.

Uredinales berberidicolas sudamericanas. Rev. Chilena Hist. Nat. 25: 263-272, 1921.

Mycetes chilensis. Bol. Acad. Nac. Cient. Córdoba 25:1-124, 1921.

Micromycetes nonulli brasilienses. Anal. Soc. Scient. Argentina $93: 111-118,1922$.

Criptogamae nonnullas fuegianae. Anal. Soc. Cient. Argentina $95: 59-85,1922$. 
Hongillos exóticos. (Exotic fungi) Bol. Acad. Nac. Cienc. de Córdoba (Argentina) 26:369-403, 1923.

Algunos hongos de la Tierra de Fuego. (Some fungi from Tierra de Fuego.) Physis 7:7-23, 1923.

Fungi paraguayenses. Anal. Mus. Nac. Hist. Nat. Buenos Aires 31: 355-450, 1923.

Revisión de las Meliolas Argentinas. (Revision of Argentine Meliolas.) Anal. Mus. Nac. Hist. Nat. Buenos Aires 32 : 339-393, 1924.

Algunos honguitos Puertorriqueños. (Some fungi from Puerto Rico.) Bol. Acad. Cient. Córdoba 26:335-368, 1924.

Relación de un paseo al cabo de Horno. (Account of a tour to cape Horno.) Bol. Acad. Cient. Córdoba 27 : 321-404, 1924.

Corothromyces Bruchi nueva Laboulbenial Argentina. Physis. Rev. Soc. Argentina Cient. Nat. $7: 236-238,1923-25$.

Un caso de intoxicación por hongos indígenos. (A case of intoxication by indegenous fungi.) Rev. Argentina Bot. 1(1): 52,1925 .

Ficomiceteas Argentinas nuevas o críticas. (New or interesting Argentine Ficomycetes.) Rev. Argentina Bot. 1:87-93, 1925.

Un nuevo género de las Helvellaceas. (A new genus of the Helvellaceae.) Mycologia 17(5):210-212, 1925.

Diagnosis and deseription of Cudoniopsis pusilla Speg. sp. nov. which occurs on Eugenia proba Berg. in Argentine.

Uredineas Argentinas nuevas o críticas. (New or interesting Argentine Phycomycetes.) Rev. Argentina Bot. 1: 87-93, 1925.

Ustilagineas Argentinas nuevas o críticas. (New or interesting Argentine Ustilagenaceae.) Rev. Argentina Bot. 1:145-156, 1925.

Contribución a la micología chilena. (Contribution to the Chilcan mycology.) Rev. Chil. Hist. Nat. 21 : 79-81, 117-126, 1917 ; 22:30-46, 95-104, 1918; 27:54-62, 1923; 28:26-30, $1924 ; 29: 26-30,58-64,1925$.

Observaciones y adiciones a la microbiología Argentina. Bol. Acad. Nac. Cien. Argentina 28:267-406, 1926. 
Contribución al conocimiento de la flora-micológica de las sierras de Córdoba. Bol. Acad. Nac. Cien. Rep. Argentina. 29: 113190, 1926.

Algunas especies de mixomicetos de la Argentina. Physis. 8: $417-419,1926$.

Ramillete patagónico. (Patagonian collection.) Rev. Argentina Bot. 1(4) : 209-227, 1926.

Nuevo caso de intoxicación por hongos frescos indígenas (New case of intoxication by fresh indigenus fungi.) Rev. Argentina Bot. 1(4) : 231-233, 1926.

Un nuevo Aspergillus patógeno. (A new pathogenic Aspergilhus.) Physis. Rev. Soc. Argentina Cient. Nat. 8:115-117, 1927.

Gasteromicetas argentinas. Physis. 8:421-435, 1927.

Observaciones microbiológicas. (Microbiological Observations.) Anal. Soc. Cient. Argentina. 85:311-323, 1928.

Nuevas orientaciones de la nosología vegetal. (New orientations on plant pathology.) Anal. Soc. Cient. Argentina 108: 82-89, 1929.

\section{Sporleder}

Beitrag zur flora der insel Porto Rico. Halle, 1853.

Stahel, Gerold

De Hevea-bladziekte van Zuid-America. (The Hevea leaf dis. ease in South America.) Meded. Dept. Land-bouw Suriname, No. 1. 1915

Marasmius perniciosus nov. sp. de verovzaker der Krullotenziekte van de cacao in Surinam. (Marasmius perniciosus n. sp. the cause of the "Krulloten" disease of cacao in Surinam.) Dept. Landb. Surinam Bull. 33, 27 p., 1915. (Agric. News (Barbados) 14(354) : 382, 1915.)

A very complete description of the disease, the origin and the results of experimental studies.

Over de besrijding der Zuid-Amerikaansche Heavea-bladziekte. (Combating the South-American Hevea-leaf diseases.) Meded. Dept. Landbouw Suriname, No. 6. 1916. 
De Zuid-Amerikaansche Hevea-bladziekte veroszaakt door $M c$ lanoysammopsis Ulci. nov. gen. (-Dothidella Ulei P. Hennings). Dept. van den Landbouw in Suriname. Bull. 34, 111 p., 1917.

De Zuid-Amerikaansehe Hevea-bladziekte op de rubberplantage der "Lawa catontchone Compagnie. (Hevea leaf-disease in Lawa.) West Indie 4: 63-64, 1919.

The disease is due to Melanopsammopsis ulei.

De Zeefvatemziekte (phloëmnecrose) van de Lriberiakoffie in Suriname. (Phloem necrosis of Liberian coffee in Suriname.) Meded. Dept. Landb. Suriname, Bull. 12, 2 p., 1917.

The author proposes the name phloem-necrosis disease due to fea. tures resembling leaf rell of potato and sereh of sugar cane.

De Solerotium-ziekte van de Liberia-koffie in Suriname. (The Sclerotium disease of Liberian coffee in Suriname.) Dept. van den Landb. Suriname Bull. 13, 1918.

This disease has been discussed by Kuyper in relation to Coreninm ap. It has been znore important every day since its tiast appearance last year. It is bricfly deseribed in regard to its development in relation to elimatie conditions.

Brijdrage tot de kennis der Ervilotenzieste. (Gontribution to our linowledges on witches' broom disaase.) Dept. van de Landbouw, Bull. 39, 1819.

Verslug 1918. Department Laudbouw Suriname. (Report 1918, Dept. of Agric. of Suriname.) Suriname Dept. Landb. 1918: 14-16, 1919.

Brief notes on crop diseases aud their control.

De Zeefvatenziekte (phloëmnecrose) van den Liberica en Suriname. (Phoemnecrosis of Liberian coffee in Suminam.) Sulinam Dept. Landb. Bull. 40. 31 p., 1920.

Continuation of previous investigations. The author concludes that the disease presents an acute form of the root disease or a cronic form causing the death of the affected parts preceded by the falling of the older leaves. He notices a great similarity with leaf roll disease of the potato known as phloem neerosis.

De Solerotium-ziekte van de Liberia koffe in Snriname, veroorzaakt door Sclerotium coffeciolum n. sp. (The Sclerotium diseases of Liberian enfee in Suriname caused by Sclerotium coffcicolum.) Dept. Landb. Suriname Bull. 42, 34 p., 1921.

Report of field and laboratory studies of this disease. The fungug Sclerotium coffeicolum was isolated which is supposed to be the cause of the disease. 
Verslag over het jaar, 1922.-Dept. van Landb. in Suriname. (Report of the Dept. of Agriculture, Suriname, for the year 1922) 106 p., 1923.

Pages 25-3I refer to diseases.

De krullotenziekte in Ecuador. (The witch broom disease in Ecuador.) West Indie 8:97-100, 1923.

The disease was discovered in Ecuador by Rorer in 1922. Many plantations have been abandoned. It attacks the "cacao blanco" (Theobroma bicolor) and "caca del monte" (T. balooensis).

Der Kaffeckirschenkafer in Suriname. Tropenpflanzer 29:79, 1926.

The South American Hevea leaf disease in Suriname. India Rubber World. 76(5) : 251-252, 1927.

Popular. The disease is caused Melanopsammopsis ulei.

Witch broom disease. Proc. Agric. Soc. Trinidad \& Tobago. $29(1): 12-18,1929$.

Popular. Attributes disease to Marasmius perniciosus. \& Bunzli, $\mathrm{H}$.

Nieuwe onderzoekingen over de zeefvatenzielkte (phoëmnecrose) van den Koff in Suriname. (New researches about phloemnecrosis of coffee in Suriname.) Indische Mercuur 53(42): 919-921, 1930.

Phloem-necrosis attacks all species of coffee (C. arabica, C. ro* busta) in Surinam, and is the most serious disease. The living sieve tubes contains a Phytomonas sp. which is similar to $P$. Davidi, but smaller.

Zur kenntnis der siebrohrenkrankheit (Phloëmnecrosis) des kaffeenbaumes in Surinam. I. Mikrospische untersuchungen und infelstionsversuche. (Contribution to the knowledge of the sieve-tube disease (phloem-necrosis) of the coffee tree in Surinam. I. Microscopic investigations and inoculation experiments.) Phytopath. Zeitschr. 4(1): 65-82, 1931.

The most serious disease of Liberian coffee in Suriname. Not known in any other country. An organism has been found in the sieve tubes which is described as Phytomonas leptovasorum:

Zur kenntnis der siebrohrenkrankheit (Phloëmnekrose des kaffeebaumes in Surinam. II. (Contribution to the knowledge of the sieve-tube disease (phloem necrosis) of the coffee tree in Surinam. II.) Phytopath. Zeitschr., 4(5):539-544, 1932.

The author reports excessive necrosis in diseased plants. The reddisease of Brazil shows similar symptom. The disease was observed in Pernambuco and Parahyba in 1917. 
Contribution to the knowledge of witch-broom disease. Trop. Agric. (Trinidad) 9(6): 167-176, 1932.

A discussion of this disease which is attributed to Marasmius perniciosus. A transiation of a paper which appeared in Bull. 39 of the Surinam Dept. Agrie.

Verslag van en Directeur (Report of the Director.) Ex Verslag ak over de jaren 1931 en 1932. Dept. Landbouw proofstat. Suriname, p. 5-34, 1933.

Notes on several crop-plant diseases observed in Surinam.

Zur Kenntnis der Siebröhrenkrankheit des Kaffeebaumes in Suriname III. (On the study of the "Sieve tube disease" (Phloemnecrosis) of the coffee tree III.) Phytopath. Zeitschr. 6(4) : 335-357, 1933.

Description of the disease and detailed account of the work done up to the present on this obscure disease.

The banana leaf disease in Suriname. Trop. Agric. (Trinidad) $11(6): 138-142,1934$.

Account of a leaf spot disease of bananas which was first noticed in 1933. The disease was first noticed on Musa sapientum variety Congo, but has spread to all varieties grown in Surinam including M. textilis. Two parasitic fungi has been isolated so far from the lesions Helminthosporium torulosum and Scolectotrichum musae.

De tagenwoordige stand van het onderzoek naar den overdragen der zeefvatenziekte van de koffie. (Actual state of the investigations on the carrier of phloem necrosis of coffee.) Landbouwproefstat. Suriname Meded. 7, 9 p., 1934.

Experimental evidence indicates that the insect Lincus sp. may be considered as the responsible for the transmission of the flagelato Phytomonas leptovasorum associated with the phloem necrosis disease of coffee. Detail of experiments.

De Krullotenziekte in Brazilië (The witches' broom disease in Brazil) Ind. Mereuur 58(6): 71, 1935.

Brief notes on witches' broom of cacao in Surinam (Marasmins - perniciosus).

Stahl, C[orwin] $F[$ loyd]

A mosaic of corn. Proc. 2nd. Conf. Internat. Soc. Sugar-Cane Tech. 2: 85-87, 1927.

The most common mosaic of corn in Cuba produces stripping. It is carried from corn to corn by Peregrinus maidis. The sugar-cane mosaic is carried from cane to corn by Aphis maidis. 
Corn-stripe disease in Cuba not identical with sugar-cane mosaic. Trop. Plant. Res. Foundation Bull. 7:3-11, 1927. (Rev. Appl. Entomology Ser. A. 17:420, 1927; Rev. Appl. Mycol. $7: 158-160,1927$.

This paper gives proof that the corn-stripe disease of Cuba which is similar to sugar-eane mosaic is different. The disease is transmitted by a leafhopper (Peregrinus maidis, Ashm.) And apparently not transmitted by Aphis maidis, Fitch.

\section{\& Faris, J[ames] A[braham]}

El comportamiento de las nuevas cañas P.O.J. en relación con la enfermedad del mosaico de la caña de azúcar en Cuba. (The behavior of the new P.O.J. cane toward mosaic.) Est. Exp. del Club Azucarero de Cuba, 13 p., 1929, (Trop. Plant Res. Foundation, Bull. 9, 12 p., 1929.)

The authors discuss the comparative resistance of several varieties, the results of inoculation of several varieties by means of Aphis maidis. The paper closes with a diseussion of resistance, immunity and tolerance.

Stakman, E. C., Hines, Lee., Cassell, Robert C., \& Levine, M. N.

Population trends of physiologic forms of Puccinia graminis tritici, 1930 to 1934. Phytopathology (Abstract) 25(1):34, 1935 .

Determinations of physiologic forms of Pucinia graminis tritici from United States and Mexico.

Starback, Karl

Ascomyceten der Schwedischen Chaco-Cordillera expedition. Ark-Bot. 57 : 1-35, 1905.

Steiner, G. \& Heinly, Helen.

The possibility of control of Heterodera radicola and other plantinjurious nemas by means of predatory nemas, ete., Journ. Wash. Acad. Sci. 12:367-386, 1922.

A nematosis of yams caused by a new species of Hoplolaimus. U.S.D.A. Plant Dis. Rep. 15(11) : 121, 1931.

\section{Stell, Frank}

Notes on fungi, Journ. Bd. Agric. British Guiana 14(1) : 39-41, 1921.

A brief discussion of smut (Ustilago maydis) of corn and red rot (Colletotrichum falcatum) of sugar cane.

Some common diseases of kitehen garden crops. (Society paper 787.) Proc. Agric. Soc. Trinidad and Tobago, 22(11) :779 $785,1922$. 
A fungus disease of cabbages. Bull. Dept. Agric. Trinidad \& Tobago 22(2-4) : 116. 1922.

Reports Fusarium conglutinans.

Wither-tip of limes in Dominica. Proc. Agric. Soc. Trinidad \& Tobago 24(4-5) : 181-185, 1924.

A study of Gloeosporium limetticolum.

Plant sanitation. Proc. Agric. Soc. Trinidad \& Tobago 27(9): 393-404, 1927.

A popular address on control of plant diseases.

Witch-broom disease of cacao and its control. Bull. Dept. Agric. Trinidad \& Tobago 21(1) : 3-14, 1928.

Plant pathology. Trinidad \& Tobago Dept. Agric. Ann. Rpt. 1928: 49-51, 1929.

\section{\& Carr, A. B.}

Witch-broom disease of cacao and its control. With an appendix: What is a fungus? by Stell. Bull. Dept. Agric. (Trinidad) 21 (3) : 3-19, 1928. (Brit. Guiana Agric. Journ. 2(2) : 109-110, 1929.)

A popular discussion of the causal organism (Marasmius perniciosus) and methods of control.

Sugar-cane mosaic in Trinidad. Int. Sugar Journ. 21(368): 414, 415, 1929. (Rev. Appl. Mycol. 9(2):131-132, 1930.)

A brief report.

Witch-broom diseases of eacao. Proc. Agric. Soc. Trinidad \& Tobago 32(1) : 23-31, 1932.

A review of the damages of this disease in Trinidad and efforts to control it.

Report of Mr. F. Stell, Mycologist, Department of Agriculture, on his visit to Ecuador to study witch-broom disease (Marasmius perniciousus) of cocoa. Trinidad and Tobago Council Paper No. 137, 12 p., 1933.

Report of Mycologist, 1933. Trinidad \& Tobago Dept. Agric. Admin. Rpt. 1933:43-45, 1934.

In this report received special attention the cacao witches' broom caused by Marasmius perniciosus, banana wilt caused by Fusarium cubense and a Helminthosporium which caused a great deal of dam. ages to this fodder grass Pennissetum purpureum. 
Banana growing and associated diseases. Proc. Agric. Soc. Trinidad \& Tobago 35(9) : 357-368, 1934.

The author briefly discusses cultural points. Panama disease (Fusarium (oxysporum) cubense) and on "moko" disease (Bacterium solanacearum) and their control.

Report of the Mycologist, 1934. Trinidad \& Tobago. Dept. Ägric. Ann. Rpt. 1934: 47-50, 1935.

Notes are given on the must prevalent and important diseases of ceonomic eroys thus: sugar eane mosaic; Banana Panama disease (Fusarium oxysporum cubense; Banana "moko" disease (Bacterium solanacearum). Cacao witches' broom (Marasmins perniciosuls). Also cacao shade trees (Erythrina velutura, and $E$. Umbrosa) infections by a species of Sphaerostilbe.

Report of the Mycologist, 1935 . Trinidad \& Tobago Dept. Agric. Rpt. 1935: 47-50, 1936.

This report includes notes on Cacao witehes' broom discase (Maras. mins perniciosus); Cacao black pod (Phytophthora palmivora); Banana Panama disease (Fusarium oxysporum cubense); Gros Michel Banana leaf spot (Cercospora musae, Cordana sp. (Scolccotrichum Afusae); Tonga bean (Dipteryx odorata) thread blight (Corticium Toleroga).

Stevens, F[rank] I, incoln]

Colecting plants in Puerto Rico. Journ. N. Y. Bot. Gard. 17 (197) : 82-85, 1916.

The genus Meliola in Puerto Rico. Illinois Biol. Mon. 2, 86 p., 1916.

Noteworthy Puerto Rico plant diseases. Phytopathology 7(2): 130-134, 1917.

Puerto Rican fungi, old and new. Trans. Illinois Acad. Sci. 10: 162-218, 1917.

Some meliolicolus parasites and commensals from Puerto Rico. Bot. Gaz. 65 : 227-249, 1918.

\section{\& Dalbey, Nora E[lizabeth]}

Some Phyllachoras from Puerto Rico. Bot. Gaz. 68(1): 54-59, 1919.

A parasite of the tree ferm. (Cyathea). Bot. Gaz. 68(3):222$225,1919$.

New or noteworthy Puerto Rican fungi. Mycologia 11(1):4-9, 1919. 
Dothideaceous and other Puerto Rican fungi. Bot. Gaz. 69(3): 24.8-257, 1920.

New or noteworthy Puerto Rican fungi. Bot. Gaz. 70(5) : 399_ 402, 1920.

Three new fungi from Puerto Rico. Mycologia 12(1):52-53, 1920.

The relation of plant pathology to human welfare. Amer. Journ. Bot. 8(6) : 315-322, 1921.

\section{\& Dowell, Ruth I.}

A meliola disease of cacao. Phytopathology 13(5) : 247-250, 1923.

A description of a leaf disease in British Guiana. The fungus is Metiota guianensis n. sp. The spots were sometimes overgrown by Helminthosporium guianensis and Nectria portoricensis. Host not given.

Parasitic fungi from British Guiana and Trinidad. Illinois Univ. Biol. Monogr. 8(3): 1-76, 1924.

\& IVIanter, H. W.

The Hemisphaeriaceae of British Guiana and Trinidad. Bot. Gaz. 79(3) : 265-296, 1925.

\section{\& Tehon, $\mathbf{L}[\mathrm{eo}] \mathbf{R}[\mathrm{oy}]$}

Species of Meliola and Irene from British Guiana and Trinidad. Mycologia 18(1) : 1-22, 1926.

Fungi from Costa Rica and Panama. Univ. Illinois Biol. Mongr. $11(2): 1-102,1927$.

New Tropical fungi. Mycologia 19(5) : 231-238, 1927.

The Meliolinae I, II. Ann. Mycol. 25:405-469, 1927. 23:165383, 1928.

Parasitic fungi Panama. Ann. Mycol. 27:281-286, 1930.

Parasitic fungi of British Guiana, Trinidad and Costa Rica. An. Mycol. 28: 364-371, 1930.

Parasitic fungi of Perú and Ecuador An. Mycol. 29:102-106, 1931.

Tropical plant pathology and mycology. Bull. Torrey Bot. Club. 59(1) : 1-6, 1932. 
Stevenson, G. C.

Foot-rot and root-rot disease of the pawpaw. Dissertation (unpublished) for the A. T. C. A., 1932.

This citation was found in Trop. Agric. 10(11): 329 but no data.

Report on the British West Indies Central Sugar Cane Breeding Station for the year ending September 30, 1934.

Report is given of observations on Bacterium vascularum on 20 different varieties of sugar cane in Barbados.

\& IMcIntosh, A. E. S.

Investigations into the root development of the sugar cane in Barbados. I. Root. development in several varieties under one environment. Bull. Brit. West Indies Centr. Sugar-Cane Breed. Stat. 5: 44, 1935.

\section{Stevenson, J[ohn] A[lbert]}

Pink disease of citrus. Corticium salminicolor. Puerto Rico Progress, April 10, p. 4, 1916.

An enemy of citrus fruits. Microcera fujiknoi. Puerto Rico Progress April 10; 4, 1916.

Report of the pathologist. Bd. Comm. Agric. Puerto Rico. Fourth Ann. 1916:33-34, 1916.

Enfermedad de la caña de azúcar en Puerto Rico. (Sugar-cane disease in Puerto Rico.) Mundo Azucarero 5(1) : 19-24, 1917. (Louisiana Planter 59:76-78, 1917.)

Wood rot of citrus trees. Puerto Rico Dept. Agric. \& Lab. Ins. Expt. Sta. Circ. 10, 10 p., 1917.

Citrus scab in Puerto Rico. Puerto Rico Dept. Agric. \& Lab. Ins. Expt. Sta. Bull. 17, 16 p., 1917.

Diseases of vegetable and garden crops. Puerto Rico Journ. Dept. Agric. 1(2) : 93-97, 1917.

Vegetable disease. Ann. Rpt. Ins. Expt. Sta. Puerto Rico. 1917: 83-98, 1917.

Report of the Pathologist. Puerto Rico, Board Comms. Agric. Ann. Rpt. 1917, 5: 35-74, 1917.

An epiphytotic of cane disease in Puerto Rico. Phytopathology $7(6): 418-425,1917$. 
La nueva enfermedad de la caña. (The new sugar-cane disease.) Puerto Rico Ins. Expt. Sta. Circ. 11, 12 p., 1917. (Louisiana Planter \& Sugar Manufac. 59: 76-78, 1917; Agric. News Barbados, 16: 286, 1917.)

A paper on the sugar-cane mosaic in Puerto Rico.

Report of the Pathologist for 1917. Ins. Expt. Sta. Puerto Rico. Ann. Rpt. 1916-17: 37-77, 1917.

A report on the presence of sugar-cane mosaic in Puerto Rico.

La enfermedad nueva de la caña. (The new sugar-cane disease.) Rev. Agric. Puerto Rico. 1(1):18-25, 1918.

A detailed popular account of sugar-eane mosaic. The author states that the disease appeared to be in the Island for several years previously; but very recently it has attracted attention and become a serious menace to the sugar industry in Puerto Rico. The anthor discusses the disease giving symptoms, suseeptible varieties, means of transmission and control measures.

The green muscardine fungus in Puerto Rico. Journ. Dept. Agric. Puerto Rico 2(1): 19-32, 1918.

Citrus diseases of Puerto Rico. Joum. Dept. Agric. Puerto Rico. 2(2): 43-123, 1918.

Check list of Puerto Rican fungi and host index. Journ. Dept. Agric. Puerto Rico 2(3): 125-264, 1918.

Notas sobre medios de combatir el matizado de la caña. (Notes on how to control sugar-cane mosaic.) Rev. Agric. Puerto Rico, 2(2) : 11-12, 1918.

Brief notes devising the means to fight mosaic of sugar cane.

La enfermedad del mosaico del tabaco. (Tobacco mosaic disease.) Rev. Agric. Puerto Rico. 2(1) : 39-44, 1918.

El matizado de la caña. (Sugar-cane mottling.) Rev, de Agric. Puerto Rico. 2(1): 51-52, 1918.

Brief note stating that mosaic is due to virus and not to fertilizerg or soil conditions.

Cuarentena de plantas. (Plants quarantine.) Rev. Agric. Puerto Rico 1(4): 176-180, 1918.

Gives reasons for quarantine.

Cuarentena de plantas en Puerto Rico. (Plant quarentine in Puerto Rico.) Rev. Agric. Puerto Rico 1(4):213-216, 1918. A review of the quarantine law. 
La enfermedad de las raíces de la caña. (The disease of sugar cane roots.) Rev. Agric. Puerto Rico. 1(6):269-279, 1918.

Refers to Mfarasmins sacchari, Himantia stellifera, Odontia saccha. ricola.

Marchitez y falta de desarrollo en las plantaciones de cacao de la República Dominicana. (Poor condition of cacao in Santo Domingo.) Rer. Agric. (Santo Domingo) 14(9):265-273, 1918.

Report of a trip to Santo Domingo.

Catálogo de Jas enfermedades fungosas y no-parasíticas que atacan las plantus ceonómicas cle P'uerto Rico. (Catalog of the fungus and non-parasitic diseases attacking economic plants in Puerto Rico.) Rev. Agr. Puerto Rico. 2(1): 19-27, 1918. 2(2) : 23-33, 1919.

The mottling or yellow-stripe disease of sugar cane. Journ. Dept. Agric. Puerto Rico. 3(3) : 3-76, 1919.

A very lengthy paper giving distribution on the Island, rate and manner of spread, varietal susceptibility, symptoms, field eulture relations, possible eauses and methods of transmission, plot experiments and methods of control.

Enfermedades del citro en Puerto Rico. (Citrus diseases in Puerto Rico.) Rev. Agr. Puerto Rico. 3(6): 25-49, 1919. $4(3): 34-46$; (4) : 25-36; (5):22, 27; (6):9-19, 1920.

Control of sugar-cane mottling disease. Sugar $23: 92-95 ; 539-$ 554, 1921.

Gives a description of the disease and advises the use of immune or resistant varieties.

Foreign plant diseases. A manual of economic plant diseases which are new to or not widely distributed in the United States. U. S. D. A. Contribution from the Fed. Hort. Board 198 p., 1926.

The South American disease of Para rubber invades Central America. U.S.D.A. Plant Disease Reporter. 19(20):308, 1935.

The disease (Dothidella ulei, P. Henn.) has been reported previously from Perú, Brazil, Trinidad, Guianas, and Bolivia. It is now reported from Costa Rica. 
Stewart, A.

Expedition of the California Academy of Sciences to the Galapagos Islands 1905-06. VII Notes on the lichens of the Galapagos Islands. Proc. California Acad. Sci. 1:431-446, 1912.

Stockdale, F. A.

Fungus diseases of cacao and sanitation of cacao orchards. Imp. Dept. Agric. West Indies Pamphlet 54, 47 p., 1906.

Coco-nut palm disease. Proc. of the Agric. Soc. of Trinidad $7: 9-31,1906$.

Coco-nut palm disease. Proc. Agric. Soc. Trinidad \& Tobago Trinidad and Tobago 7:45, 1906.

Coconut palm disease. Bull. Dept. Agric. Jamaiça 5(6-7) : 111139, 1907.

A discussion of a root disease, a leaf disease and a bud-rot disease which may be the same as has been referred to by other writers.

Fungus diseases of pine-apple. West Indian Bull. 8(2) : 158166, 1907.

A discussion of tangle root, blight, black heart or core rot and storage disease.

Coconut palm disease. Trinidad Royal Gazette, p. 350, 361362, Feb. 1907.

The principal fungus diseases of cacao. Soc. paper 324, Proc. Agric. Soc. Trinidad \& Tobago 8:279-287, 1908.

Popular discussion of stem canker (Nectria calonectria, etc.), dieback (Diplodia cacaoicola), pink disease (Corticium lilaco-fuscum), thread blights, root diseases, brown pod (Diplodia cacaoicola) and black pod (Phytophthora palmivora).

Root diseases of sugar cane. Soc. paper 333. Proc. Agric. Soc. Trinidad \& Tobago 8:377-386, 1908. (West Indian Bull. $9(2): 103-116,1908$.)

Popular discussion of diseases attributed to Marasmins sacchari and related species.

Fungous diseases of cacao and sanitation of cacao orchards. West Indian Bulletin 9(2) : 166-189, 1908.

This paper includes a discussion of root diseases: canker (Nectria ditissima), N. Bainii, N. theobromae and Calonectria flavida, die-back (Diplodia cacaoicola), pink disease (Corticium lilaco-fuscum), thread blights (Marasmius equicrinus), brown pod (Diplodia cacaoicola), black rot (Phytophthora omnivora), scabby pod (Lasiodiplodia sp.) 
Fungous diseases of coconuts in the West Indies. West Indian Bull. 9(4) : 361-371, 1909.

Popular.

\section{Sturgis, William C[odman]}

Myxomycetes from South America. Mycologia 8(1):34-41, 1916.

Sutherland, J. B.

Banana breeding, etc. Jamaica Journ. Agric. Soc. 36(9) :463465, 1932.

A lecture describing methods for the control of Fusarium oxysporum cubense.

\section{Swingle, Walter 'T.}

Danger of introducing a Central American coffee disease into Hawaii. U. S. D. A. Div. of Veg. Phys. \& Path. Circ. 16, 4 p., 1898.

In this paper the author warned the Hawaiian planters as to the danger of introducing into Hawaii from Brazil the following coffee pests: Stilbella flavida, Sphaerella coffeicola, Hemileia vastatrix and nematodes.

Sydow, Hans, \& Sydow, Paul

Fungi aliquot novia F. Stuckert in Argentina lecti. Mem. Herb.

Boisser, 4: 1, 2, 1900.

Fungi novi brasiliensis a cl. Ule lecti. Bul. Herb. Boisser, ser. 2, 1:77-85, 1900.

\section{\& Sydow, Paul}

Beitrag zur Pilzflora Sud-Amerikas. (Contribution to the fungus flora of South America.) Hedwigia, Beiblat 42:105-106, 1903.

Verseichnis der von Herrn. F. Noack in Brasilien gesammetten Pilze. Ann. Mycol. 5:348-363, 1907.

\section{\& Sydow, Paul}

Fungi paraënsis. Hedwigia 49 : 78-84, 1909.

\&

Contribution a l' étude des champignons parasites de Colombie. In Fuhrmann, O. Voyage d' exploration scientifique en Colombia. Mem. Soc. Newclat. Sei. Nat. 5(2): 432-441, 1914.

\section{\&}

Novae fungorum species. Ann. Mycol. 11:254-271, 1913; 12 : 195-204, 1914; 13:35-43, 1915. 
466 THE JOURNAL OF AGRICULTURE OF THE UNIVERSITY OF P. R.

$\&$

Fungi amazonici a el. E. Ule lecti Ann. Mycol. 14:65-97, 1916.

Taxonomic; Records Ustilago Paniei-petrose, U. veneruela, Falso nectria orbiculata as now species.

$\&$

Novae fungorum species. (New fungi species) Ann. Mycol. 15: $143-148,1917$.

Rust of British Griana and Trinidad. Mycologia 17(6) :255$262,1925$.

Fungi chilensis a cl. E. Werdermann. lecti. Ann. Mycol. 26(1/2): $100-126,1928$.

Novae fungorum species XIX. Ann. Mycol. 26:133, 1928.

Frangi in itinere costauicensi coliecti. Ann. Mycol. 23:306429. 1925; 24: 283-426, 1026; $36: 1-160,1927 ; 26: 127-131$, 1928.

\& Petravis, 5

Fungi Costaricenses a cl. p:of. Alberto M. Brenes collecti Ser. I. An. Mycol. $27: 1-86,1829$.

Fungi venezuelani, Ann. Mysol. $28(1 / 2): 20-224,1930$.

Fungi chilensis a cl. B. Werdermann leoti. Ann. Mycol. 30 : $81-90,1932$.

Novae fungortum specics XXT. (New fungi species, XXI.) Ann. Mycol. 30: 91-117, 1382.

Novae fungorum species-XXII. (New fungi species XXII.) Ann. Mycol. 33: 286-299, 1934.

Fungi venezuelaui-Additamentum. (An addition to Venezuelan fungi.) Ann. Mycol. Berl. 33(1-2):85-100, 1935.

Taxononic.

Tamajo,

La epifitia cocoteros. Rev. Agric. (Cuba) 9:557-558, 1889.

Tehon, $\mathrm{s}$ [eon] $\mathrm{R}$ [oy]

Studies of some Porto Rican fungi. Bot. Gaz. 67(6) : 501-511, 1919.

\section{Téllez, Oliverio}

La mancha de hierro en los cafetales de Oaxaca. (The "iron stain" of the coffee trees in Oaxaca.) Bol. Dir. General Agric. (Mexico) 1(7): 671-680, 1911. 
Las anguilulas de las raíces del cafeto. (The coffee root nematodes.) La Hacienda 7(4):119-121, (5) :147-148, 1912.

Description of the coffee-root nematode Heterodera radicicola and the favorable conditions for its development. Discussion on control methods. Among the substances tested were: carbon sulfocarbonate, carbon bisulfate, soap mixtures, petroleum and tobacco. The best results were obtained with lime carbide.

Una plaga en el estado de Jalisco: La "pinta" o clavo de la naranja $y$ de la guayaba. (A pest in the State of Jalisco: The "spot" or linob disease of the orange and guava.) Rev. Agric. (México) 6(11):651-652, 1922.

The disease is caused by Gloeosporium psidii.

Thierry, A. I.

Notes sur le greffage et la maladie vermiculaire du caféier. (Notes on grafting and the vermicular disease of coffee.) Bull. Agric. Martinique, 1899.

rempany, H. A.

The root disease of sugar cane in Antigua. West Indian Bull. 10(4) : 343-347, 1910.

A discussion of Marasmius sacchari.

Thexter, Roland.

New or critical Laboulbeniales from Argentine. Proc. Amer. Acad. Arts \& Sci. 48:155-223, 1912.

Zheissen, Frerdinand

Xylariaccae austro-brasiliensis. Ann. Mycol. 7:1-18, 140-167, 1909.

Fungi riograndenses. Berith. Bot. Centralbl. II. Abt. Systematik $27: 384-411,1910$.

Hypocieaceas riograndenses. Broteria 9:121-147, 1910.

Die hypocreaceen von Río Grande do Sul, Sudbrasilien. (The Hypocreaceae from Rio Grande of the South, South Brazil.) Ann. Mycol, $9: 40-73,1911$.

Fragmenta brasilica. Ann. Mycol. 6:531-535, 1908; 7:343353,$1909 ; 8: 452-463,1910 ; 10: 1-32,159-204,1912$.

Hemisphaeriales. Ann. Mycol. 11: 468-4.69, 1913.

Annotacaes a mycoflora brasileira. (Annotation to the Brasilian mieroflora.) Broteria 12:13-31, 1914.

Mycologische Mitteilungen. (Mycological notes). Ann. Mycol. $16: 184,1918$. 
Xylariaceae austro-brasiliensis. I Xylaria In Wettstein R. \& Shiffner, V. Ergebnisse der botanishen expedition der Akademie der wissenschaften nach Südbrasilien 1901. V 2. Denkschr-Nath.-Nuturw Kl. Akad. Wiss. Wien 83:47-86, 1927.

Polyporaceae austro-brasilienses imprimis Rio Grandenses. In

Wettstein, R. \& Schiffner, V. Ergebnisse der botanischen expedition der Akademie der wissenschaften nach Südbrasilien 1901. V a Denkschr. Nath. Naturw. Kl. Akad. Wiss. Wien 83 : 213-250, 1927.

\section{Theissen, S. J., \& Sydow, Hans}

Die Dothideales. Ann. Mycol. 13:149-746, 1915. \&

Die Gatutng Parodiella. (The Genus Parodiella.) Ann. Mycol. 15 : 230, 1917.

Synoptische Tafeln. Ann. Mycol. 15: 389-491, 1917.

\section{Thistelton-Dyer, William T.}

Note on the sugar cane disease of the West Indies. West Indian

Bull. 2(3) : 211-216, 1901.

This paper contains a historical discussion of the rind disease of sugar eane and a brief diseussion of root diseases.

Thomas, H. E.

Vegetable diseases. Vanilla diseases. Citrus diseases. Puerto Rico Agric. Expt. Sta. Report 1917:28-30, 1918.

Brief notes on several diseases and the fungi causing them.

Cultures of Aecidium tubulosum and A. passifloricola. Phytopathology 8(4): 163-164, 1918.

Thamplkins, R. G.

Wastage in banana transport. Trop. Agric. (Trinidad) 8(10): 255-264, 1931.

A very complete discussion, but very little data on fungi.

Thorold, C. A.

A further preliminary list of Trinidad fungi. Govt. Printing Off. Port of Spain. 30 p., 1931.

Fusarinm wilt disease of sun hemp II. Trop. Agric. (Trinidad) 8(7): 176-177, 1931.

\section{Thümen, Félix von}

De fungis enterianis observaciones. Separat-abdrack aus: Dr. Don P. G. Lorentz. "La vegetación del nordeste de la Provincia de Entre Ríos." Buenos Aires (Argentina) p. 99-102, 1878. 
Pilzen aus Entre-Píos. (Fungi from Entre-Ríos.) Flora 63: $30-31,1880$.

Thurston, Jr. E[any] W[infred], \& Kern, F[rank] D[unn]

Distribution of West Inclian rusts. Mycologia 25(1):58-64, 1933.

Tims, B. C., \& Mills, P. J.

Some fungi associated with the root disease of sugar cane in

Louisiana. Ref. Book \& Sugar Ind, of the World. 5:33-37, 1927 .

Give a discussion of Marasmins plicatus, Rhizoctonia and Pythium.

\section{Tondtz, Adolio}

Informe sobre la enfermedad del cafeto. (Report on the coffee disease.) San José (Costa IRica) Inst. Fis. Geo. Nac. Ser. Bot. 28 p., 1893.

Discussion of a disease of coffee named in Costa Rica the "spot", which causes the falling of the leaves and berries.

Enfermedades del cafeto. El "chasparro" de las ramillas del cafeto. (Cofiee tiseases. The "chasparro" of the coffee-tree twigs.) Costa Rica Mem. de Fomento 1913: 380-381, 1914.

Brief description of a cofies disease in Costa Rica, named the "ehasparro". It causes a die back of young twigs of coffee.

\section{Toro Rafael A[ndrés]}

Una lista de los Pirenomycetes coleccionados en Puerto Rico por F. J. Seaver y C. E. Chardon. (A list of the Pyrenomycetes collected in Puerto Rico by F. J. Seaver and C. E. Chardon.) Rev. Agrie. Puerto Rico 13(5) : 319-332, 1924.

Studies on banana anthracnose. Journ. Dept. Agrie. Porto Rico. $6(4): 3-23,1922$.

A thorough study of banana antinracnose caused by Glocosporium: musarum. (Published in 1924.)

Una enfe'medad importante de las cebollas en Puerto Rico. (An important onion disease in Puerto Rico.) Ins. Expt. Sta. Puerto IRico Circ. 71, 6 p., 1923.

Popular description of an onion disease produced by Macrospoporium parasitioum.

Report of the Division of Botany and Plant Pathology. Puerto Rico Ins. Expt. Sta: Ann. Rpt. 1922-23: 59-61, 1924.

New or noteworthy Puerto Rican Pyrenomycetes. MIycologia $17(4)$ : 131-147, 1925. 
La influencia del ambiente en la protección de las plantas contra enfermedades. (Influence of the environment in the protection of plants against diseases.) Ins. Expt. Sta. Puerto Rico Circ. 90, 10 p., 1925.

Popular.

Mycological notes I. Journ. Dept. Agric. Porto Rico 10(2): 11-23, 1926.

La caída de las bellotas del algodón. (The falling of cotín bolls.) Rev. Agric. Puerto Rico. 16(1):17-18, 1926. Attributed this disease to Diplodia gossypina.

Fungi of Santo Domingo I. Mycologia 19(2) : 66-85, 1927.

Las enfermedades y plagas del cafeto y árboles de sombra en Argentina. (The diseases and pests of coffee and shade trees in Argentina.) Bol. Agric., Medellín, (Colombia) 73, 1927.

Notas micológicas colombianas. (Mycological notes from Colombia.) Rev. Soc. Colombiana de Cienc. Nat. 18:42-43, 1929.

Un nuevo parásito del eafeto en Cundinamarca. (A new eofiee parasite in Cundinamarca.) Rev. Cafetera de Colombia 2 (13) : 437-438, 1929.

Report of a coffee-root parasite, the nematode Caconema radicicola (Greef.) Cobb. It is reported for the first time from Colombia. Deseribes symptoms of the disense that it causes and gives methods of control.

Plant-disease notes from the Central Andes II. Phytopathology 19(10): 969-974, 1929.

Continuation of previous work on the coffee-root disease and a leaf spot caused by the fungus Cercospora coiffeicola Berk. \& Curt.

Cultivos-Una epitofita del café en Cúcuta. (Crops-An epiphyte of coffee in Cúcuta.) Rev. Cafetera de Coiombia 2(56) : 171-173, 1929. (Rev. Ind. (Bogotá) 5(58): 304-305, 1929.)

Description of the coffee disease caused by the fungus Corticium koleroga. Control measures are given.

Colombia: Crop disease and pests. Internat. Bull. Plant Protect. 4(1):3-4, 1930.

Krankheiten und Feinde der Kulturpflanzen. Int. Anz. Pflanzensehutz 4: 3-4, 1930. 
The Cercosporae of Puerto Rico. Journ. Dept. Agric. Porto Rico 15(1): 5-17, 1931.

Nuevas enfermedades de la palma de coco en Puerto Rico. (New coconut palm diseases in Puerto Rico.) Rev. Agric. Puerto Rico 26(8) : 42-44, 1931.

Popular account of four coconut palm diseases.

Especies de Asterina Lév. en las Melastomaceas. (Species of Asterinas Lév. on the Melastomaceae.) Bol. Soc. Esp. Hist. Nat. 33(5) : 187-199, 1933.

Torre, Carlos de la

La enfermedad de los cocoteros. (Coconut palms disease.) Fac. Let. \& Cienc. Univ. Habana 2: 269-281, 1906.

Torrend, Camillo

Les myxomycetes du Brésil, connus jusque'ici. Broteria, Bot. ser. $13: 72-88,1915$.

Insect and vegetable parasites of the cocoa-tree in the State of Bahia, Brazil. Int. Rev. Sci. \& Pract. Agric. 9(4) : 523-524, 1918.

\section{Tower, W[inthrop] $\mathrm{V}$ [ose]}

Report of the entomologist and plant pathologist. Porto Rico Agric. Expt. Sta. Ann. Rpt. 1906: 25-28, 1907.

Report of the entomologist and pathologist Puerto Rico. Agric. Expt. Sta. Ann. Rept. 1907:31-38, 1908.

Insects injurious to citrus fruits and methods for combating them. Puerto Rico. Agric. Expt. Sta. Bull. 10, 35 p., 1911.

Mottling disease of sugar cane. Puerto Rico Agric. Expt. Sta. Ann. Rpt. 1919 : 21-25, 1920.

Citrus scab-Puerto Rico Agric. Expt. Sta. Exten. Note. 53. 2 p., 1923. (Trop. Agric. (Ceylon) 60(4): 224-226, 1923.) Popular.

\section{Townsend, C[harles] H[enry] T[yler], \& Abbott, E[rnest]}

V[íctor]

Enfermedades y pestes observadas en los cultivos de la Montaña Central, Departamento de Junín, Húsnuco.) (Diseases and pests observed in the central mountain crops. Department of Junín, Húsnuco.) Est. Expt. Agron. de la Soc. Nac. Agraria, Lima, Perú. Informe 1, 1927. 


\section{Townsend, $\mathrm{C}$ [harles] $\mathrm{O}$ [rrin]}

An immune rariety of sugar cane. Science $49(1276): 470-472$, 1929.

Refers to work of F. S. Earle on Kavangire.

\section{Trujillo Peluffo, Augustín}

El Oidium y modo de combatirlo. (Oidium and the method of combating it.) Defensa Agric. (Uruguay) 1:120-121, 141, 1920.

The powdery mildew of the grape.

Desarrollo de las enfermedades er'iptogámicas en los viñedos durante el presente año. (Fungous diseases in the vineyards during the present year.) Defensa Agric. (Uruguay) 2:4346, 1921.

A report on powdery mildew (Oidium), Anthracnose (Glocosporizm) and downy midew (Plasmopara).

Uruguay: Pests and diseases of plants. Int. Bull. Plant Protec. $10(2): 29-30,1936$.

Bricf notes on several diseases of economic plants.

\section{Tucker, o[larence] M[itchell]}

Report of the acting plant pathologist. Puerto Rico Agric. Expt. Sta. Amn. Rept. 1922: 16-18, 1924.

Reports a Helminthosporium on rice and Fusarium cubense.

Report of the Plant Pathologist. Puerto Rico Agric. Expt. Sta. Ann. Rpt. 1923: 15-16, 1924.

Refers to Fusarium cubense, Sporotrichum citri, Bacterium solanacearum, Fusarium lycopersici and Fusarium sp. on vanilla.

Report of the Plant Pathologist. Coconut bud rot. Puerto Rico Agric. Expt. Sta. Ann. Rpt. 1924: 26-29, 1924.

This disease is caused by Phytophthora palmivora. Refereneo is also made to Fusarium cubense of the banana and a Fusarium on the roots of vanilla.

La pudrición del cogollo del cocotero en Puerto Rico. (Coconut bud rot in Puerto Rico.) Rev. Agric. Puerto Rico 12(6): 385-390, 1924. (Trop. Agric. (Ceylon) 63(2):89, 1924.)

Popular. 
Coconut but rot experiments in Porto Rico. Scienee n.s. 61 (1572) : 186-187, 1925.

A brief note stating that a small chlamydospored strain of Phytophthora faberi Maublane had been isolated from coconut palms infected with coconut-bud rot.

La enfermedad de la raíz del cafeto en los semilleros. (Coffee root disease in the nurseries.) Rev. Agric. Puerto Rico 13 (3) : 129-131, 1926.

Brief notes deseribing the disease and giving preventive methods.

Enfermedad negra de los semilleros de las raíces del cafeto. (Black disease of the coffee root in the seed beds.) Puerio Rico Agric. Expt. Sta. Agric. Notes 23, 2 p., 1926.

Brief notes discussing the disease and giving prerentive methods. Much the same as the preceding.

A leaf, bract and boll spot of sea-island cotton caused by $\mathrm{Hel}$ minthosporium gossypii n. sp. Journ. Agric. Res. 32(4) : 391$395,1926$.

A deseription of the disease and the fungus.

Phytophthora but rot of coconut palms in Puerto Rico. Journ. Agric. Res. 32(5): 471-498, 1926.

A comprehensive paper on this disease which is due to Phytophthora palmivora.

Report of the Plant Pathologist. Puerto Rico Agric. Expt. Sia. Ann. Rpt. 1925:24-40, 1927.

Reports Fusarium sp. on vanilla, experimental studies with Phy. tophthora, Rhizoctonia formuginea on sugar eane and Cajanus indicus and other common diseases.

Report of the plant pathologist. Puerto Rico Agric. Expt. Sta. Ann. Rpt. 1926: 28-30, 1927.

A report our the campaign for the eradication of coconut bud-rot which is eaused by Phytophthora palmivora. 'i'he hat palm (Sabal causiarum) was found to be infected. Reference is asso made to a root disease of vanilla due to a fungus similar to Fuscrium batatis and to an anthracnose of the pod of the pigeon pea caused by Colletotrichum cajani.

Pigeon pea anthracnose. Journ. Agric. Res. 34(6):589-596, 1927.

Colletotriehum cajani was found attacking Cajanus indicus. 
Sabal causiarum (Cook) Beceari: A new host of the eoconut bud-rot fungus. Journ. Agric. Res. 34(9) : 879-888, 1927.

The disease is caused by Phytophthora palmivora. This fungus will attack several other host plants, especially when they are wounded.

Vanilla root rot. Journ. Agric. Res. 35(12) : 1121-1136, 1928. The fungus is described as Fusarium batatis var. vanillae.

Report of the plant pathologist. Puerto Rico. Agric. Expt. Sta. Ann. Rpt. 1927: 25-27, 1929.

Report of the plant pathologist. Puerto Rico. Agric. Expt. Sta. Ann. Rpt. 1928: 29-35, 1929.

Enfermedades del cafeto en América. (Coffee diseases in America.) Bol. Unión Panamericana 62:1020-1034, 1928. (Rev. Agric. Puerto Rico 22(7) : 27-31, 1929.

The coffee diseases which the author describes and gives distribution are: black-root disease (Rosellinia bunodes (B. \& Br.) Sacc.), white-root disease, "iron stain", thread blight (Corticium koleroga (Cooke) Höhm.), spot of the berry (Cercospora coffeicola Berk. \& Curt.), and Sclerotium disease (Sclerotium coffeicolum Stahel.)

Report of the plant pathologist. Puerto Rico Agric. Expt. Sta. Ann. Rpt. 1929 : 24-25, 1930.

Taxonomy of the genus Phytophthora de Bary. Missouri Agric. Expt. Sta. Res. Bull. 153, 208 p., 1931.

The distribution of the genus Phytophthora. Missouri Agric. Expt. Sta. Res. Bull. 184, 80 p., 1933.

Unamuno, L. II.

Reliquiae Fragosoanae (Material left by Fragoso) Bol. Soc. Española Hist. Nat. 35(7) : 395-402, 1931.

A Latin diagnosis is given of Septoria americana Frag. \& Herrera on Willow (Salix sp.) from México.

\section{Urban, Ignacio}

Bibliographia Indiae occidentalis botanica contimatio II. Symb. Ant. 3:1-13, 1902.

Bibliographia Indiae occidentalis botanica contimatio III. Symb. Ant. 5:1-16, 1904.

Urich, F. W.

Miscellaneous notes. Trinidad Bd. Agric. Circ. 3:15-25, 1911. 
Notes on the fungoid and insect pests. Proc. of the Soc. of Trinidad and Tobago 13(4): 186-187, 1913.

A brief paper in which the author refers to cacao canker (Phytophthora) and brown rot (Diplodia) and chupon wilt of cacao.

Fungoid and insect pests. Soc. paper 554. Proc. Agric. Soc. Trinidad \& Tobago 13(4) : 186-187, 1913.

Popular. Mentions Phytophthora and Diplodia of eacao.

Utra, Gustavo d'

A molestia do "mosaico" de fumo (Mosaico disease of tobacco.) Bol. Agric. Sao Paulo (Brasil) 5(2) : 51-71, 1904.

\section{Valle Zeno, Rafael del}

Mottling or yellow stripe disease of sugar cane. Some facts relative to the importance of the discovery of the "morbid" cause. Published privately with 2 color plates by author, New York, 1919.

Gives symptoms and effect of the disease. Claims to have discovered the great secrets of cause and control.

Vélez, Ramón

El mosaico del tabaco. (Tobacco mosaic.) Rev. Agric. Puerto Rico 10(2) : 25-26, 1923.

A brief popular discussion.

Verteuil, J[oseph] de, \& Brunton, I. A.

Sugar cane experiment, 1919-1922. Trinidad and Tobago Dept. Agric. Bull. 19(4) : 188-214; 20(2-4) : 65-109, 1922.

\section{Veve, $\mathbf{R}[a f a e l]$ A.}

The eradication of sugar-cane mosaic in Fajardo. Ins. Expt. Sta. Puerto Rico Cire. 33:52-55, 1920.

La represión del matizado en Fajardo. (Mosaic eradication in Fajardo.) Rev. Azucarera \& Agricultura, Puerto Rico. 1: 96-98, 1921.

The efficiency of "Roguing" method for the eradication of mottling disease. Louisiana Planter 69(2) : 30, 1922.

The disease was reduced from 0.5 to 0.002 per cent. Believes that roguing can be practiced where the percentage of disease is less than 15 per cent.

Cane mottling eradication. Facts About Sugar 15(4) : 78, 1922.

Overcoming the mosaic disease at Fajardo. Facts About Sugar 18(20): 468, 1924.

Mosaic has been overeome by roguing. 


\section{Vincens, ㅍ.}

Necrose nes fuilles de pin clue an Pestalozzia truncata Leveille. (Necrosis of pine leaves caused by Prstalozzia trunala) Bull. Soc. Path. Veg. Franee 5:27-31, 1918.

This fungus attacks Pimus sylvestris. It is believed to be same as P. hastigii.

Quelques maladies desplantes an Para, Brasil. (Some diseases of cultivated plants of Para, Brazil.) Bull. Soc. Path. Veg. France 5: 45-55, 1918.

Discusses Cercospora nicotianae, C. orizae, Lasiodiplodia theobromae, Phyllosticta theobromicola n. sp. Glocosporium theobromicolum n. sp. and Dendrodochinm paraense n. sp.

Vidal, I. I.

El mosaico de la caña de azúcar. (Mosaic of sugar cane.) Tipografía Cercantes, San Pedro de Macoris, Rep. Dominicana. 44 p. 1931. (Facts About Sugar 26:503, 1931. Brasil Açcareiro 9(5) : 348-354, 1937.)

A popular text-book.

Viola, P., \& Pacottet, P.

Nouvelles recherches sur l'anthracnose. Bur. Rev. Viticola 65 p., Paris, 1905.

\section{Vizioli, đosé}

Estudido preliminar da molestias das folhas do eafeiro causadas pela Hcmileia vastatrix. (Preliminary studies on the coffeeleaf disease caused by Hemileia vastatrix.) Bol. Agric. Sec. Agr. Com. \& Obras Pub. S. Paulo, 23(3-4) : 87-118; (5-6) : $152-188,1923$.

This very interesting paper deals witl a rather extensive general discussion on the fungus Hemileia vastatrix, which is unlwown in the Western Hemisphere. Includes a bibliograplyy of 55 titles.

Some Pyrenomycetes of Bermuda. Nycologia 15(3): 107-119, 1923.

W. ส. T. [Freeman]

An algal disease of cacao. Cephalcuros virescons. Dept. Agrie. Trinidad \& Tobago. Bull. 13(83) : 263-264, 1914.

A brief popular diseussion.

Wakefield F[loise] M[aud] (F. M. W.)

Mosaic disease of cane. Sugar 23:500-501, 1921.

Bracket fungi disease. Agric. News 19(487) : 414, 1920.

Refers to the subject and to Ganoderma lucidum (Fomes licidus) in roots of limes in Monserrat and Antigua. 
Mosaic disease of plants. West Indian Bull. 18(4):197-206, 1921.

\section{Walker, M[arion] N[ewman,] \& Stahl, C[orwin] F[loyd]}

Certain grass hosts of the corn aphid considered in relation to their occurrence in Cuba. Trop. Plant Res. Foundation Bull. 5:318, 1326. (Rev. Appl. Ent. Ser. A. 15:379, 1926.)

This paper gives the results of studies of sugar-eane mosaic on other hosts.

Walters, ․․․ A.

Die-back of limes (Citrus medica var. acida.) Proc. Ninth West Indian Agric. Conf. 192A: 232-234, 1925.

Observations made in St. Lucia.

Report of the Agricultural Dept. of St. Lucía (West Indies) $1925: 33,3926$.

Contains recouds of several common diseases: Marasmius sacchari, Wakker, Leptosphaeria sacchari, Br. d. H., Cercospora vaginae $\mathrm{K}$. and Bacterium vascularum (Cobb.) (E. F. S.) Also Phytophthora and Diplodia of cacao and bud rot of coconut, Glocosporium limetticolum Clausen of lime and Fusarium cubense D. F. S. of banana. Rosellinia on eacso roots. Little leaf, stem bleeding, wilting leaf and leaf yellows, bitten leaf and senility of coconut.

Control of fungus diseases. West Indies Imp, Dept. Agrie. St. Lucía Dept. Agrie. Ann. Rpt. 1926: 10-11, 1927.

Report on the Agricultural Department of St. Lueía, $1933: 18$ $19,1934$.

Notes on the following crop diseases: limes, oranges, caca, grapefruit and coconuts.

Report of the Agricultural Department of St. Lucía 1934:16$19,1935$.

This report ineludes notes on red root of limes (Sphaerostilbe repens), wither-tip (Glocosporium limetticolum), coconut-bud rots (Phytophthora palmisora) and a coconat. little leaf, banana Panama disease (Fusarium oxysportm cubonse.)

Report on the Dept. Agric. St. Lucia, 1935: 30-32, 1936. Account of the Panama disease of bananas in the Island.

Ward, H. Marshail

Report on specimens of diseased amount. Kew Bull., 1893: 203, 1893.

Wardlaw, C. W. \& McQuire L[awrence] P[atrick]

Panama disease of bananas. Empire Marketing Board, Rep. 20, 1929. 
Panama disease research. Trop. Agric. (Trinidad) 6(7):192197, 1929.

This paper is a summary of two reports by the author submitted to the Empire Marketing Board. It gives a review of the results obtained by the author.

Witch-broom in Suriname. Trop. Agrie. (Trinidad) 6(12) : 348349, 1.929.

A short paper on a disease of eacao which the author attributes to Marasmius perniciosus.

Banana-fruit disease. A review of the literature of fungal diseases of banana fruits. Trop. Agric. (Trinidad) 7(5):115, 1930.

Panama disease research (Fusarium cubense.) Trop. Agric. (Trinidad) 7(10) : 278-281, 1930.

A discussion of results.

Banana-fruit disease. Trop.Agric. (Trinidad) 7(10): 285, 1930. A brief note in which the author says: "In a review of literature on Banana fruit diseases published in Vol. VII, No. 5 of this Journal. Cercospora musae and $C$. musarum both of which are banana leafsplitting fungi, were wrongly regarded as identical. Mr. S. F. Ashby of the Imperial Bureau of Myeology has kindly supplied the following information: "Cercospora musae Zimm. (C. musae Mass.) Appears to be restricted to the East-Ceylon, Java, some Pacifie Islands and Australia, while C. musarum, Ashby, which is a distinct species is known only from South America, the West Indies and West Africa. The new name Helminthosporium torulosum (Syd.) comb. nov. has been proposed for the latter species."

The biology of banana wilt (Panama disease). I. Root inoculation experiments. Ann. Bot. 44(175) : 741-766, 1930.

Studies on this disease which is due to Fusarium cubense.

The biology of banana wilt. (Panama disease.) Ir. Preliminary observations on sucker infection. Ann. Bot. 44(176): 917$956,1930$.

A report on extensive studies of this disease which is caused by Fusarium cubense. Continuation of previous works.

\section{\& IIcQuire, Lawrence P[atrick]}

The behaviour and diseases of the banana in storage and transport. Empire Marketing Board Report 36, 74 p., 1931. H. M.S.O., (Trop. Agric. (Trinidad) $7(7): 188-189,1930$ ).

A preliminary discussion and results of experiments. The following fungi were observed at low temperature: Thielaviopsis paradoxa 
(De Seyres) von Hohn., Ceratostomella paradoxa (Dade.), Gloeosporium musarum (Cke. \& Massee), Botryodiplodia theobromae (Pat.), Phomopsis sp. Acremoniella sp., Eidemia sp. Verticillium sp., and Fusarium spp.

\section{\& McQuire, Lawrence P[atricls]}

Panama storage. The behaviour and diseases of the banana in storage and transport with special reference to chilling. Trop. Agric. (Trinidad) 8(6): 139-147, 1931.

A report.

Panama disease. I. Observations on Botryociplodia fruit rot of the banana. Trop. Agric. (Trinidad) 8(9):227-230, 1931.

A deseription of the disease caused by Botryodiplodia theobromae. Also a description of the organism.

Banana diseases. II. Notes on "cigar-end" (Stachylidium theobromae Turc.) Trop. Agric. (Trinidad) 8(11): 293-298, 1931.

The eigar end is caused by S. theobromae and the black tip by Helminthosporium torulosum (Cercospora musarum).

Banana diseases. III. Notes on the parasitism of Gloeosporium musarum (Cook \& Massee). Trop. Agric. (Trinidad) 8(12): 327--331, 1931.

A discussion of the fruit rot caused by G. musarum.

\section{\& MicQuire, Lawrence R[atrick]}

Transport and storage of banana with special reference to chilling. E.M.B. Report No. 45, 1931.

The biology of banana wilt III.-An examination on sucker infection through root bases. Ann. Bot. 45(179) : 381-399, 1931.

\section{\& McQuire, Lawrence $P$ [atrick]}

Pitting disease of bananas. Its nature and control. Trop. Agric. (Trinidad) 9(6):193-195, 1932.

This disease also occurs in Brazil. It appears to be due to Piricutaria grisea (Cke.) Sace. The author gives a discussion of the disease and the fungus.

Fusarium cubense. Trop. Agrie. (Trinidad) 8(3):54-60, 1931. A very complete discussion of studies on this fungus.

\section{\& MicQuire, Lawrence P[atrick]}

The behaviour and diseases of the banana in storage and transport. Proc. 1. Imp. Hort. Conf. Liondon $1930(3): 52-60$, 1930. (Trop. Agric. (Trinidad) 8(6):139-147, 1931.) 


\section{\& Mcouire, Lawrence P[atrick]}

Control of wastage in bananas with special reference to time and temperature factors. E. M. B. Report No. 60, 1932.

Observations on the Pycuidium of Botryodiplodia theobromae Patt. Ann. Bot. 46(182) : 229-238, 1932.

\section{\& McQuire, Lawrence P[arick]}

Whe storne of tropically grown tomatoes. Empire Marketing Board Pab\}. 58, 50 p., 1932.

Temperature studies.

Banana cliseases. IV. Notes on "black-tip" disease in Trinidad; Helminthosporim torulosum (Syd.) comb. nov. Ashby. Trop. Agric. (Trinidad) 9(1):3-6, 1932.

A continuation of former studies.

Banana diseases, IX. The occurrence of Sigatoka disease (Cercospora musae) Zimm.) on Banana in Trinidad. Trop. Agric. (Trinidad) 9(7):173-175, 1932.

The first record of the disease in Trinidad.

\section{\& IMcQuire, Iawrence P[atrick]}

Preliminary observations on the siorage of limes, with a note on the king orange. Trop. Agric. (Trinidad) 10(7):190-191, 1933.

Storage trials in which Penicillium was an important factor.

Notes on a frusarium tip-rot of immature Cavendish fruits. Trop. Agric. (T'rinidad) 10(1): 6, 1933.

This paper refers to cigar end Stachylidium theobromae and black tip Holminthosporium torulosum (Sydow) com. n. Ashby.

\section{Ieonard, T. R. \& Baker. R. E. D.}

Observations on storage of various fruits and vegetables. I. tomatoes, canliflower, string beans, egg plant, cucumber and muslimelons. II Papaws, pineapples, granadillas, grapefruit, and oranges. Trop. Agric. (Trinidad) 9(8):196-200, (9): 230-235. 1932.

A study of low temperature. Refers to the following fungi: Colletotrichum lagenarium, Fusarium spp., including F. suceisae, Mycossphaerclla citrulina, Cladosporium cucumerinum and Macrosporium cucumerinum (Alternaria cucumerina), Phomopsis papayae, Fusarium dimerum var. pusillum, Penicillium italicum, P. digitatum, Phomopsis (Diaporthe) eitri and Colletotrichum gloeosporioides.

Panama disease. A review of the occurrence of Panama disease in the Cavendish or dwarf banana. Trop. Agric. (Trinidad) $10(6): 151-154,1933$.

A discussion of the cause, spread and treatment of the disease. 


\section{\& McQuire, Irawrence $P$ [âricir]}

Tomato storage. Further observations on the storage of tropically grown tomatoes. Trop. Agric. 10(6):161-163, 1933.

$I_{12}$ the latter paper the anthor gives a list of fungi and bacteria found in rejected fruits.

\section{$\&$}

Cultivation and diseases of the banana in Brazil. Part II. Diseases. Trop. Agric. (Trinidad) 10(8):211-217, (9):255-259, 1933.

This paper is based on investigations in Sao Paulo. The discussion includes (9) an infectious chlorosis transmitted by Pentalonia nigronervosa which is unlike the bunchy top of Australia; (10) brotn rot of bulbs of unlnown cause; (11) a stem-root rot caused by Marasmius semiustus; (12) a black-head disease of unknown cause; (13) debility resuiting from unfavorable planting conditions; (14) a leaf-spot disease in which a fungus (Scolecotrichum musae Zimm.) was found; (15) a black finger tip disutse believed to be alue to sunscorch and (16) a pitting disease.

$\&$

Banana storage. An account of recent investigations into the storage behavior of several varieties. Trop. Agric. (Trinidad) 10(12) : 336-339, 1933. (E. M. B. Report No. 72, 1933.)

Banana diseases. VI. The nature and occurrence of pitting disease and fruit spots. Trop. Agric. (Triniclad) $11(1): 8-13$, 1934.

A very excellent discussion of this disease from which several fungi have been isolated.

Banana diseases. VIIL. Notes on various diseases occurring in Trinidad. Trop. Agric. (Trinidad) 11(6): 143-149, 1934.

A diseussion of methods and a list of fungi that were isulated.

Banana disease. VIII.-Notes on varions diseases necurring in Trinidad. Trop. Agrie. (Trinidad) 11(6): 143-149, 1934.

Continuation of the author's notes on banana diseases. Gives deseription of the disease and spread.

Banana diseases. IX.-The occurrence of Sigatoka disease (Cercospora musae Zimm.) on Bananas in Trinidad. Trop. Agric. (Trinidad) 11(7):173-175, 1934.

In this paper the author reports the recent discovery of Cercospora musae Zimm. on bamanas in Trimidad. This is the first record of this fungus oceurring in the American Tropies. 


\section{\& McQuire, Lawrence P[atrick]}

The storage of West Indian mangoes. Mem. Low Temp. Res. Sta. (Trinidad) 2., 47 p., 1936.

The authors found in their investigations that there is a close relation between mango anthraenose (Gloeosporium mangiferae) and the physiology of ripening. The disease is also manifested as a blight on the flowers and setting of fruits. An account is also given of the blemishes produced by Pestalozzia funerea and a Phomopsis.

\section{Watts, Francis}

On legislating against plant diseases. West Indian Bull. 15(3): 158-161, 1915.

Withertip disease of limes. Agric. Dept. (Dominica) Rept. $1922-23: 10-16,1923$.

A report on this disease which is attributed to Colletotrichum gloeosporioides.

\section{Weir, James Robert}

A pathological survey of the Para rubber tree. (Hevea brasiTiensis) in the Amazon Valley. U. S. D. A. Bull. 1330, 130 p., 1926.

The problem of Dichrostachys nutans, a weed tree in Cuba with remarks on its pathology. Phytopathology 17(3):137-146, 1927.

This tree is attacked by Ganoderma pulverulentum and Ustulina zonata.

Wellman, F. Is.

Progress in Fusarium wilt inside the rhizomes of banana plants. Phytopathology (Abstract) 21(1): 121, 1931.

\section{Went, F[riedich] A[ugust] F[erdinand] C[hristian]}

Notes on cane diseases. Ann. Bot. $10(40): 592,1896$.

De ziekteverchijuselen van de cacao plant in Suriname, S' Gravenhage, 1903.

Krulloten en verpteende vruchten van den cacao in Surinam, (A witches' broom disease of cacao in Suriname.) Verhandl K. Akad. Wetensch. Amsterdam Sec. 10, 2(3) : 40, 1904. (Bot. Centbl. (Abstract) 96(40):358-359, 1904.)

Does the Sereh disease exists in the West Indies, more especially in Trinidad. West Indian Bull. 12(4) : 554-560, 1912.

He found suspicious eases but no positive eases.

Discussion on witch-broom disease. Proc. Agric. Soc. Trinidad \& Tobago, 28(9):381-390, 1928. 
Wost, J.

Mycological Notes. Trop. Agric. (Trinidad) 7(8): 223, 1930.

A discussion of Rhizoctonia solani attacking cotton and cacao. The pathogenicity of this fungus was treated on 24 eover crops. Negative results were obtained on maize.

\& Struckey, W. R.

Macrophomina phaseoli (Maub.) Ashby in Trinidad. 1.-

Parasitism. 2.-Physiology. Mem. Imp. Coll. Trop. Agric.

Mycol. ser. (Trinidad) 4, 20 p. 1931.

Westling, 'R.

Über die grünen spezies der Gattung Penicillium (On the green species of the Genus Penicillium) Arkiv. Bot. 11(1):1-156, 1911.

Weston, W[illiam] H[onxy] Jr.

Phycomycetes. In Chardon and Toro, Mycological Exploration of Colombia. Journ. Dept. Agrie. Puerto Rico. 14(4):215$225,1930$.

The fungi of Barro Colorado. Sci. Mon. 36:387-407, 1933.

Whetzel H[erbert] H[ice]

Report of the pathologist for the period June 10 to Dec. 1931. Bermuda, Bd. and Dept. Agrie. Repts. 1821: 30-64, 1922.

The seed potato situation. Bermuda Dept. Agric. Bull. 1922: $2-4,1922$.

hocords leaf roll, mosaic, early blight, late blight and seab of pctato; pink root of onion; Septoria blight and black heart of celery; strmp rot and black scale or root rot of lilies; Recommendations.

Special Report Board \& Dept. of Agric. (Bermuda) 1923:4552, 1924.

Reports Peronospora schleideniana (P. Schleideni), Phytophthora infestans, Puccinia antirrhini, Septoria apii and Fusarium malli.

\& Kern, Frank D[unn]

The smuts of Puerto Rico and the Virgin Islands. Mycologia $18(3): 114-124,1926$.

\section{\& Jackson, H[erbert] S[pencer]}

The rusts and smut of Bermuda. Trans. Brit. Mycol. Soc. 13 (1-2) : 1-32, 1928.

Wilew, D. R. D.

Sugar-cane mosaic disease. Barbados Dept. Agric. Ann. Rpt. 1927-28: 16-18, 1928.

Report of the work during the year in regard to sugar-cane mosaic eradication. 
Report of the plant diseases inspector for the year 1928-29. Ann. Rept. Dept. Agr. Barbados for the years, 1928-29:8588, 1930. (Rev. Appl. Mycol. 9: 560, 1930.)

A record of sugar-eane mosaic.

\section{Williams, $C$ [arrington] $B$ [onaur]}

The mosaic disease of sugar cane in Trinidad. Trinidad \& To bago Dept. Agric. Bull. 19(1) : 30-37, 20.

A review and varietal studies.

The mosaic disease of sugar cane. Trinidad \& Tobago Dept. Agric. Bull. 9(2) : 49-50, 1921.

Sugar-cane pest and disease in Trinidad in 1920. Trinidad and Tobago, Dept. Agric. Bull. 19(3) : 111-112, 1921. (Rev. Appl. Mycol. 1: 192-194, 1921.)

A general discussion of the subject.

Williams, Holman 'B.

La gommose a la Guadeloupe. Journ. Stat. Agron. Guadeloupe. $7(2): 106-116,1929$.

The author found this disease in sugar cane in Guadeloupe and published this popular account.

Williams, R. 0.

Limes and wither-tip. Introduction and breeding work in Trinidad. Trop. Agric. (Trinidad) 6(7): 187-191, 1929.

A popular discussion of this disease which is due to Gloeosporium limetticolum.

Wither-tip disease and limes. Proc. Agric. Soc. Trinidad \& Tobago. 35(7): 275-282, 1934.

Data on losses caused on limes due to Gloeosporium limetticolum the fungus responsible for the disease known as wither-tip of limes. It ranges from Florida to British Guiana.

Williamson, Juan

Caries y carbón de las plantas cultivadas. (Caries and smut of cultivated plants.) Nuestra Chacra (Argentina) 3(13):912 ; (14): 8-11, 1928.

Popular account of the subject with special reference to wheat.

Wilson, G. W.

Studies in North American Peronosporales-I Genus Albugo. Bull. Torrey Bot. Club. 34: 61-84, 1907.

\section{Wilson, Percy}

The vegetation of Vieques Island. Bull. New York Bot. Gard. $8(31)$ : 379-409, 1917.

Lists some fungi of the area. 
Wiltshire, S. P.

The wither-tip disease of limes. Kew Bull. Misc. Inform. 1925 (10) : 401-403, 1925.

Winter, G.

Refers to Gloeosporium limetticotum in Dominica.

Exotische pilze I, II, IV. Reprint from Flora 1884-1887.

Wolcott, George $\mathbb{N}$ [orton]

The minor sugar-cane insects of Puerto Rico. Journ. Dept. Agric. of Puerto Rico 5(2):5-46, 1921. (Rev. Appl. Ent. ser. A. 10:96-98, 1922.)

Annual Report of the Div. of Entomology. Puerto Rico. Ins. Expt. Sta. Ann. Rpt. 1920-21: 47-49, 1922.

Brief note of the work of the year concerning sugar-cane mosaic.

Informe anual de la División de Entomología. Puerto Rico, Ins. Expt. Sta. Report 1922-23 : 33, 1923.

Preceding annotation.

El áfido del maíz, Aphis maides Fich. (The corn aphis, Aphis maides Fich.) Puerto Rico. Expt. Sta. Bull. 32:43, 1924.

Popular note. Deseription of the insect as vector of sugar-cane mosaic.

Los áfidos que afectan a la Industria azucarera del Perú. (Aphis that affect the sugar industry in Perú.) La Vida Agrícola (Perú) 5(59) : 877-886, 1928 . (Estac. Expt. Agron. Soc. Nac. Agrar. Circ. No. 12, 1928. (Rev. Appl. Ent. Ser. A. 17: 99. 1928.)

Increase of insect transmitted plant disease and insect damage though weed destruction in Tropical Agriculture. Ecology 9(4) : 461-466, 1928.

Refers to the passage of Aphis maidis from grasses to sugar cane after cultivation, which is followed by an inerease in mosaic.

Mosaic Sugar cane in Perú. Science n. s. 69(1788): 381, 1929.

The first records of the mosaic disease of sugar cane in Puerto Rico. Journ. Agric. Univ. Puerto Rico 19(2) : 117-120, 1935.

The author gives data of early records of virus disease of sugar cane in Puerto Rico as early as March 26, 1915.

Wood, E. J. F.

Gummosis in Barbados. Trop. Agric. (Trinidad) 6(12):340, 1929.

Wright, C. H.

Leaf disease of Hevea. India Rubber Journ. 70(23):15-17, 1925.

The most important rubber diseases in South America and the East. 
Wright, J., \& Leach, R.

Fusarium wilt disease of sun hemp.-I. Trop. Agric. (Trinidad) $8(6)$ : 151-160, 1931.

This disease attacks Crotalaria juncea and C. usaramoensis and is caused by a fungus related to Fusarium udum Butler. The author deseribes the symptoms and the fungus and give the results of extensive experimental work.

Yglesias, R. IM.

Enfermedades del cafeto. La mancha de la hoja (Stilbella flavida). Diseases of coffee. A leaf spot due to $S$. flavida.)

(Costa Rica) Centro Nacional Agric. Bol. 4:1-15, 1929.

\section{Young, Esther}

Studies in Puerto Rican parasitic fungi I. Mycologia 7(3) : 143150, 1915.

Studies in Puerto Rican parasitic fungi II. Mycologia 8(1) : 4246, 1916.

\section{Zeman, V[íctor]}

Los hongos de la Phalaris bulbosa. (The fungi of Phalaris bulbosa.) Rev. Facul. Agron. Univ. La Plata, Argentina. 14: 179-184, 1921.

Bacteriosis del bananero (Una nueva enfermedad). Rev. Fac. Agron. Univ. Nacional La Plata, Argentina 14(2) : 17-30, 1921.

A deseription of a bacterial disease and of the organism Bacillus musarum n. sp. The disease eauses a dying back from the tip (Podredumbre del cogollo). The characters on different media are described.

Bacteriosis del bananero (Una nueva enfermedad.) Bol. Cámara Agric. (Costa Rica) 1:253-256, 1921. 2:23-32, 1922.

A very thorough description of the disease and the organism. Attacks Musa cavendishii, M. sapientum and M. paradisiaca. Caused by Bacillus musarum Zem. n. sp.

Lepra explosiva del naranjo. (The "Leper" explosiva of the orange-tree.) 29 p. Univ. Nacional del Litoral, Corrientes (Argentina) 1932.

A deseription of the causal agent, Amylirosa aurantiorum with three metagentic forms: Pseudohaplosporella, Paradiplodia and Esphelidium.

\section{Zwaluwenburg, R. H. van, \& Thomas, H. E.}

Some means of controlling insect, fungi and other pests in Puerto Rico. Puerto Rico Agric. Expt. Sta. Circular 17, 30 p., 1918. 